
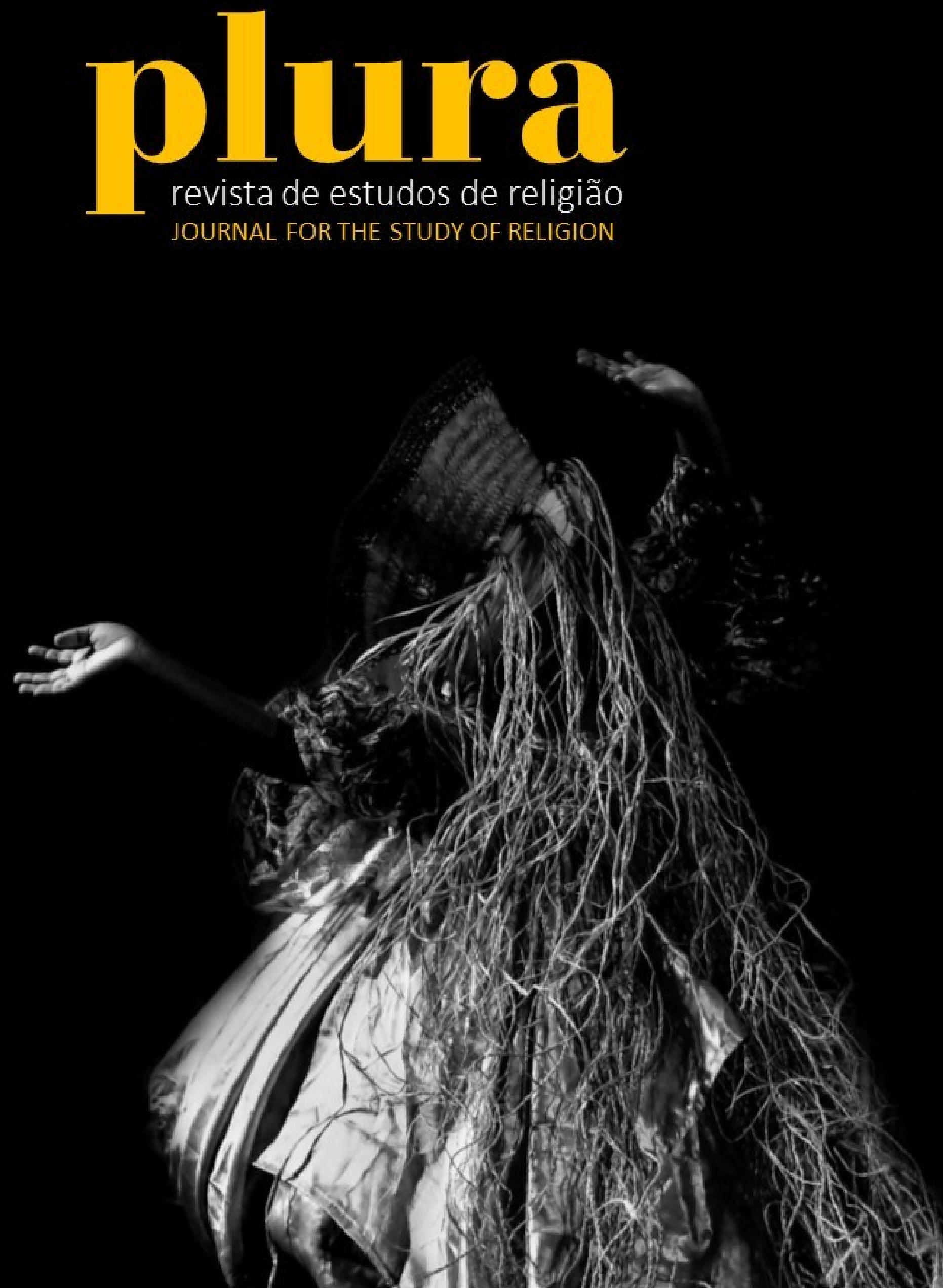


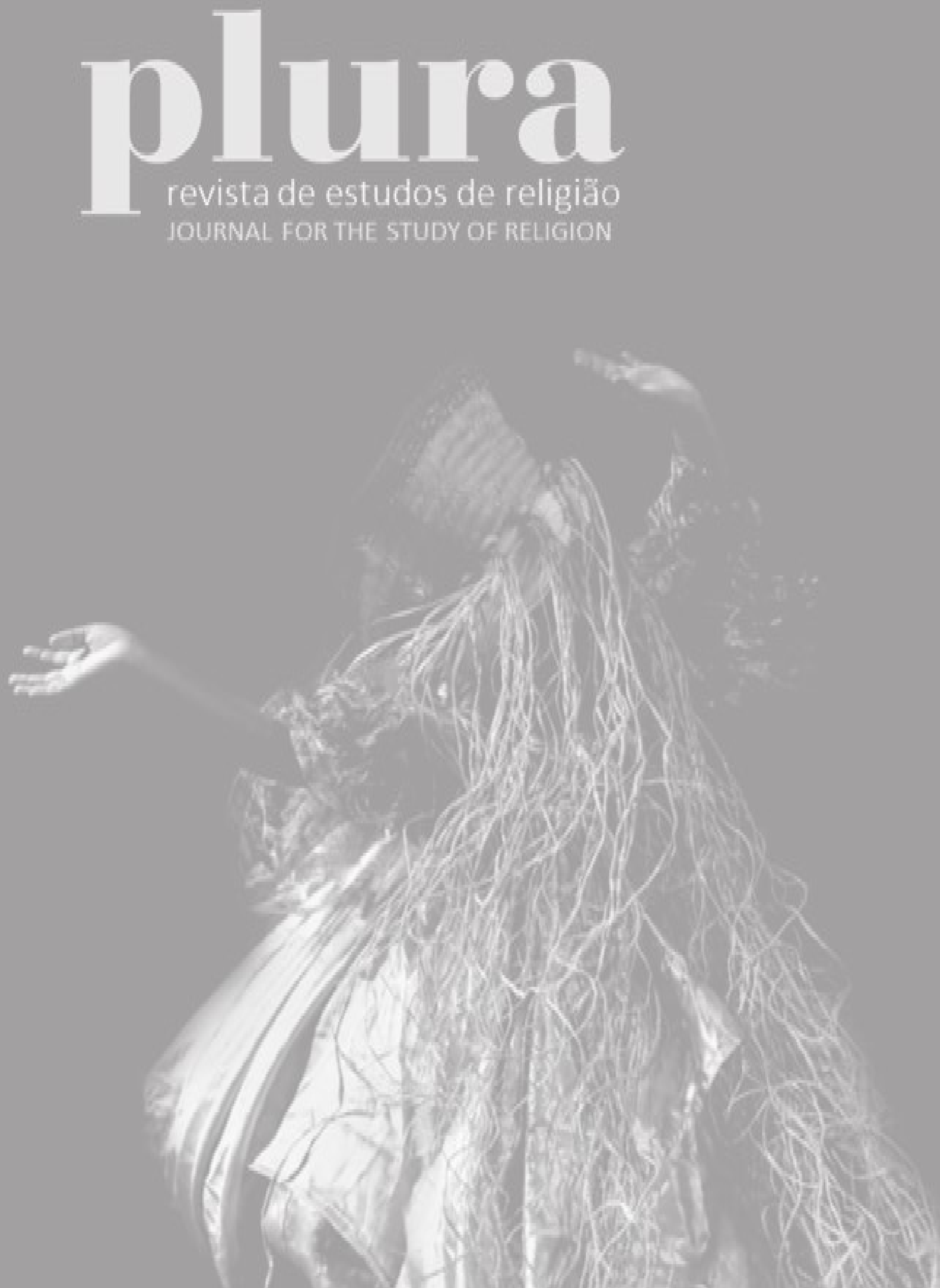


\section{Associação Brasileira de História das Religiões}

\section{Diretoria Executiva (2019-2021)}

Presidente: Me. Diego Omar da Silveira, Universidade do Estado do Amazonas Secretária de divulgação: Dra. Bruna Marques Cabral, Universidade Federal Rural do Rio de Janeiro

\section{Comissão Científica}

Dr. Emerson José Sena da Silveira, Universidade Federal de Juiz de Fora Dra. Leila Marrach Basto de Albuquerque, Universidade Estadual Paulista Dra. Mabel Salgado Pereira, Centro de Ensino Superior de Juiz de Fora Dra. Sandra Duarte de Souza, Universidade Metodista de São Paulo

\section{Comissão de Redação (2020-2021)}

Dr. André Dioney Fonseca, Universidade Federal de Mato Grosso do Sul, editor chefe

Dr. Bruno da Silveira Albuquerque, Associação Brasileira de História das Religiões, editor colaborador

Paulo Sérgio Raposo da Silva, Universidade Federal do Rio Grande do Norte, editor colaborador

Silvio Lucas Alves da Silva, Universidade Federal do Oeste do Pará, estagiário

\section{Conselho Editorial}

Dr. André Droogers, Vrije Universiteit Amsterdan, Holanda

Dr. Artur Cesar Isaia, Universidade Federal de Santa Catarina, Brasil

Dr. Dain Borges, University of Chicago, EUA

Dr. Jean-Pierre Bastian, Université de Strasbourg, França

Dr. Joanildo Burity, Faculdade Joaquim Nabuco, Brasil

Dr. Luís Henrique Dreher, Universidade Federal de Juiz de Fora, Brasil

Dr. Paul Freston, Wilfrid Laurier University e Balsillie School of International

Affairs, Canadá

Dr. Pedro A. Ribeiro de Oliveira, Pontificia Universidade Católica de Minas

Gerais, Brasil

Dra. Rosalind I. J. Hackett, University of Tennessee, EUA

PLURA, Revista de Estudos de Religião

Associação Brasileira de História das Religiões

v. $12, \mathrm{n}^{\circ} 2,2021$

308 p.

Semestral

ISSN: $2179-0019$

https: / / doi.org/10.29327/256659.12.2

Foto da capa do ensaio Atako: retratos da sobrevivência, de Roger Silva

Arte final de diagramação: Diego Omar da Silveira

Revisão dos títulos e abstracts: Matheus Landau de Carvalho 


\section{Sumário}

\section{Apresentação}

07 A Plura e a ABHR em transição: nova fase, novos tempos

Diego Omar da Silveira

Bruna Maques Cabral

09 Religiões no Nordeste

Irinéia MariaFranco dos Santos e Renato Amado Peixoto

\section{Dossiê temático: Religiões no Nordeste}

13 Experiênciasdefronteira:asinterfacesentreserdocrimeeser evangélico/a Ada Rizia Barbosa de Carvalho

38 Lideranças leigas, adequações e conflitos na evangelização do sertão cearense na primeira metade do século XX

Robério Américo do Carmo Souza

60 Congregacionais e a Renovação Espiritual no Nordeste

Heitor Lamartine

80 Circuitos evangélicos do Nordeste: contexto geral e caso potiguar Waldney de Souza Rodrigues Costa

101 Narrativas e histórias sobre o início da Umbanda em Teresina Ariany Maria Farias de Souza e Regina Weber

122 Entre sambas e feitiçarias: a experiência afro-religiosa do xangô em Maceió - AL, no imediato pós-abolição (1889-1900)

Lilia Rose Ferreira

137 As Comunidades Eclesiais de Base e a recomposiçãodas formas de militância católica no Maranhão (1970-1980)

Wheriston Silva Neris

164 A copa do Juazeiro é verde, as raízes são alagoanas Francisco Airton Bastos Silva Filho

182 A estirpe de conselheiros do catolicismo popular sertanejo do nordeste brasileiro

João Everton da Cruz Santos 
206 Contextualizações do Ensino Religioso na educação públicamunicipal de Juazeiro do Norte - Ceará: diálogos possiveis

Rogério Paiva Castro e Ercília Maria Braga de Olinda

222 Breve historiografia do gênero musical missa no Brasil e as três missas nordestinas do movimento armorial

Carlos Eduardo Brandao Calvani

\section{Artigos de temática livre}

241 Religião e poder estatal no Brasil: da Colônia à República

David Mesquiati de Oliveira, Leila Miranda Damasceno, Lucia Maria Roriz Verissimo Portela e Robson Prati Neves de Oliveira

259 Jesus histórico e a américa-latina: desenvolvimento econtribuições em meio à Teologia Latino-Americana

Mateus Soares Guedes e Flávio Schmitt

278 Estados de consciência místicos e Transe capoeirano:uma interpretação da obra de mestre Decanio à luz dopensamento de William James

Cicero Cunha Bezerra

\section{Resenha}

295 O Discurso sobre Deus na Pós-Modernidade Elias Gomes

\section{Pareceristas}




\section{A Plura e a ABHR em transição}

The Plura and ABHR Religions in transition

Diego Omar da Silveira*

Bruna Maques Cabral

https://doi.org/10.29327/256659.12.2-2

A Plura e a Associação Brasileira de História das Religiões começam, agora, uma nova fase, rumo a tempos que - todos esperamos - sejam menos turbulentos e de horizontes mais amplos.

Nos últimos dois anos, lutamos para que nossa Associação se mantivesse de pé. Também para que se reencontrasse com seu legado acadêmico e seu protagonismo na própria constituição do campo dos estudos da religião no Brasil. Em 2019, quando compusemos uma diretoria interina, estávamos cientes que nossa tarefa era promover essa transição, serenar os ânimos, ampliar os espaços de diálogo e, na medida do possivel, reunir todas as forças e pessoas interessadas em manter a ABHR viva e atuante.

Essa reconstrução, lenta, inclusive porque nos deparamos nesse percurso com todos os desafios extras impostos pela pandemia, começou pela formação de novas coordenações regionais. Uma interlocução que, também aos poucos, pavimentou o caminho para a realização do XVII Simpósio Nacional, em parceria com o II Simpósio Nacional de Estudos da Religião da Universidade Estadual de Goiás. O evento, realizado online entre os dias 23 e 26 de novembro de 2021, teve, assim, um sabor de retomada. Mesmo à distância, pudemos discutir com pesquisadores bastante qualificados temas de primeira importância, não apenas para a

\footnotetext{
"Mestre em História pela Universidade Federal de Ouro Preto (UFOP) e doutorando em Antropologia Social pela Universidade Federal do Amazonas (UFAM). Professor do Centro de Estudos Superiores de Parintins (CESP) da Universidade do Estado do Amazonas (UEA). E-mail: diegomarhistoria@yahoo.com.br.

${ }^{* *}$ Doutora e mestra em História na Universidade Federal Rural do Rio de Janeiro (UFRRJ). Coordenadora do Grupo de Pesquisa História e Catolicismo: Da Neocristandade ao Tempo Presente e membro do Laboratório de História das Experiências Religiosas (LHER). Trabalha atualmente como professora de História da rede municipal de São João de Meriti e na rede estadual do Rio de Janeiro. E-mail: brunaclio@uol.com.br.
} 
nossa agenda de estudos, mas também para o momento político e social que vive o nosso país.

As ideias e colaborações para que o projeto ganhasse corpo vieram de muitas pessoas e lugares, de modo que o sucesso do Simpósio se deve a um esforço coletivo, ou, como dizem no Norte do Brasil, a um grande puxirum. Entretanto, devemos ressaltar o papel de destaque que merecem nesse processo os professores da UEG, a quem agradecemos na pessoa de Robson Gomes Filho, e o prof. Waldney de Souza Rodrigues Costa (UERN), parceiro incansável e decisivo em todo o planejamento do evento.

As assembleias, realizadas durante o Simpósio, serviram para que pudéssemos contextualizar esse nosso percurso de pouco mais de 2 anos e para pensarmos, juntos, nossos projetos futuros. Com a missão parcialmente cumprida e com alegria nos corações, estamos também entregando a ABHR a uma nova gestão, a qual confiamos igualmente a tarefa de conduzir nossa revista, que já acumula mais de 10 anos de história(s) e uma grande contribuição às ciências sociais da religião no Brasil.

Estamos certos de que esse movimento de construção institucional depende de todos nós, e, por isso, convidamos todos os leitores e colaboradores da Plura a se filiarem a ABHR. De igual modo, desejamos sorte e sucesso a todos que aceitaram aceitar essa tarefa.

Parintins, AM/ Rio de Janeiro, RJ, 15 de dezembro de 2021

\section{Diego Omar da Silveira \\ Bruna Marques Cabral}




\section{Apresentação Religiões no Nordeste}

Religions in NortheasternBrazil

Irinéia Maria Franco dos Santos*

Renato Amado Peixoto**

https://doi.org/10.29327/256659.12.2-3

Nossa principal intenção ao abrir a chamada para o dossiê Religiões no Nordeste, em 2020, era proporcionar um espaço amplo para mais as variadas pesquisas desenvolvidas na área de estudos da religião que possuem como recorte esse espaço regional e local. E, pela própria abrangência da Revista Plura as contribuições recebidas não se restringiram à nossa área de atuação, a História, mas se distribuíram também pela Sociologia, Filosofia, Ciências da Religião, Antropologia e Teologia, proporcionando um retrato bastante amplo da formação dos seus pesquisadores, ainda que a grande maioria deles esteja inserida em instituições de ensino da própria região Nordeste. No entanto, é o foco desses estudiosos que oferece o dado mais interessante para se pensar o estado do estudo das religiões que tem com o escopo o Nordeste: todos os textos do Dossiê concentram-se no eixo mais tradicional do campo, o já consagrado tripé protestantismo, catolicismo e religiões afro-brasileiras. Ainda que as abordagens dos textos sejam bastante diversas e criativas, este dado pressupõem, a nosso ver, a necessidade de se incentivar também o avanço da pesquisa e observações no Nordeste em direção a outras religiões, em nome da diversidade e da inclusão.

De todo modo, procedemos à organização do dossiê Religiões no Nordeste dividindo os textos em três blocos (protestantismo, religiões afro-brasileiras e catolicismo), e, em cada um dos blocos, partindo do específico para o geral (do

*Doutora em História pela Universidade de São Paulo (USP). Professora do Programa de PósGraduação em História da Universidade Federal de Alagoas. E-mail: irineia.franco@ichca.ufal.br.

**Doutor em História pela Universidade Federal do Rio de Janeiro (UFRJ). Professor do Programa de Pós-Graduação e do Departamento de História da Universidade Federal do Rio grande do Norte (UFRN). E-mail: renatoamadopeixoto@gmail.com. 
local ao regional). No bloco dedicado ao protestantismo, o primeiro artigo, "Experiências de fronteira", de autoria de Ada Carvalho, faz uma reflexão sobre a interpenetração entre religiosidade e criminalidade, abordando a fronteira entre as facções criminosas e o mundo evangélico. No segundo texto, "Lideranças leigas, adequações e conflitos na evangelização do sertão cearense na primeira metade do século XX",escrito por Robério Souza, se busca refletir sobre a importância das lideranças leigas na difusão do protestantismo pelo sertão do Ceará. Já o terceiro artigo, "Congregacionais e a Renovação Espiritual no Nordeste", de Heitor Lamartine, examina a revitalização religiosa das Igrejas Batistas e Congregacionais na década de 1960. Por sua vez, no quarto texto, "Circuito evangélico do Nordeste”, Waldney Costa procura contextualizar a presença evangélica na Região, utilizando como laboratório a cidade de Natal.

Já no quinto artigo, "Narrativas e histórias sobre o início da Umbanda em Teresina", abrindo o bloco dedicado às religiões afro-brasileiras, Ariany Souza e Regina Weber buscam discutir o processo de constituição da religiosidade umbandista em Teresina. Por sua vez, no sexto texto, denominado "Entre sambas e feitiçarias", Lília Ferreira analisa as experiências do Xangô na cidade de Maceió. No bloco que junta os artigos sobre o catolicismo, o sétimo texto, "As comunidades eclesiais de base e a recomposição das formas de militância católica no Maranhão (1970-1980)", de autoria de WheristonNeris, busca abordar as reconfigurações contemporâneas das formas de militância católica através da análise da criação e evolução das comunidades eclesiais de base na região maranhense. $O$ oitavo artigo, “A copa do Juazeiro é verde, as raízes são alagoanas", escrito por Francisco Silva Filho, busca examinar a identidade dos romeiros alagoanos em visita e peregrinação ao túmulo do Pe. Cícero na cidade de Juazeiro do Norte. Ainda no campo dos estudos do catolicismo popular, o nono texto de João Everton da Cruz, intitulado "A estirpe de conselheiros do catolicismo popular sertanejo do nordeste brasileiro" trata desse fenômeno religioso identificando possíveis relações entre as tradições do catolicismo e as culturas indígenas e africanas.

Os textos finais que compõem o dossiê, décimo e décimo primeiro, exemplificam a variação das possibilidades de pesquisas no campo religioso nordestino, conectando as dinâmicas religiosas nos âmbitos da educação e dos estudos musicais, respectivamente. Rogério Castro e Ercília de Olinda apresentam em "Contextualizações do Ensino Religioso na educação pública municipal de Juazeiro do Norte - Ceará: diálogos possíveis" os avanços do debate naquele municí- 
pio das possibilidades de um ensino religioso que promova uma melhor compreensão da sociedade e do mundo, o reconhecimento da liberdade de expressão religiosa e não religiosa, e a promoção e a defesa da dignidade humana. Por fim, Carlos Calvani, no texto "Breve historiografia do gênero musical missa no Brasil e as três missas nordestinas do movimento armorial", apresenta os esforços de inculturação pós-Vaticano II com a intenção de divulgar e informar a pesquisadores/as interessados/as no assunto, especialmente liturgistas, músicos e pastoralistas, a grande fecundidade da cultura brasileira e seu potencial de resistência à globalização gospel que atinge também certos setores do catolicismo brasileiro com os "padres cantores".

Os/As leitores/as poderão comprovar através da leitura do Dossiê Religióes do Nordeste que, nos três eixos principais - protestantismo, religiões afrobrasileiras e catolicismo - exemplarmente apresentados nos artigos, mantêm-se uma diversidade de experiências próprias a esses campos, ao mesmo tempo em que dialogam e/ou conflitam, o que nos permite inferir que o caminho para a consolidação dos espaços sociais democráticos para as diferentes religiões na região Nordeste e no Brasil, como um todo, avança na medida do aumento do conhecimento, valorização e respeito pelas diferenças. Vale lembrar, que o direito humano à liberdade religiosa, passa necessariamente pela equidade e a justiça nas relações socioeconômicas, étnicorraciais e de gênero.

A edição ainda nos traz Artigos de Temática Livre, que incorporam outros debates necessários aos estudos do campo religioso como um todo, sempre em diferentes abordagens. Abrindo a seção, o artigo "Religião e poder estatal no Brasil: da Colônia à República” de David Oliveira, Leila Damasceno, Lucia Portela e Robson de Oliveira, analisa a relação entre o poder estatal e a religião nas Constituições brasileiras, desde o período colonial até a Constituição Federal de 1988. Já Mateus Guedes e Flávio Schmitt em "Jesus histórico e a América-latina: desenvolvimento e contribuições em meio à Teologia Latino-Americana" investigam como a Teologia Latino-americana vê o Jesus histórico e constrói sua teologia a partir dele, além de observar as implicações para a sociedade.

Na sequência, o artigo "Estados de consciência místicos e Transe capoeirano: uma interpretação da obra de mestre Decanio à luz do pensamento de William James", de Cícero Bezerra, propõe compreender em que medida é possível sustentar o caráter místico do transe capoeirano, proposto por Decanio, como 
uma forma particular de êxtase que ocorre pela interação entre três niveis que constituiriam o psíquico humano: consciente, inconsciente e estados modificados de consciência. Por fim, certos de contarmos com a leitura atenciosa e dedicada da comunidade acadêmica à qual este dossiê se destina, desejamos a todos uma boa experiência crítica, de aprofundamento reflexivo e ampliação de horizontes teóricos. 


\title{
Experiências de fronteira: as interfaces entre ser do crime e ser evangélico/a
}

Border experiences: interfaces between being criminous and being evangelical

Ada Rizia Barbosa de Carvalho*

https://doi.org/10.29327/256659.12.2-4

\section{Resumo}

Neste artigo, por meio das trajetórias de dois interlocutores, ensaio algumas reflexões sobre as experiências de mobilização de uma gramática religiosa no crime, e sobre as experiências de conversão e desengajamento das redes criminaisa partir de atuações em igrejas e congregações, especificamente no contexto das margens urbanas alagoanas. Tem-se como objetivo contribuir com a compreensão das experiências da religiosidade evangélica no Nordeste do país. Proponho o argumento de que as experiências religiosas e do crime se tensionam, interpenetram, e, consequentemente, implicam na forma como são enunciadas as identificações: sou do crime e sou evangélico/a, uma vez que esta religiosidade parece funcionar como uma espécie de espelho moral para as posturas, performances e gramáticas.

Palavras-chave: Religião; Crime; Margens; Interfaces.

\begin{abstract}
In this article, through the trajectories of two interlocutors, I essay some reflections about the experiences of mobilizing a religious grammar in the crime, and about the experiences of religious conversion and disengagement from criminal networks through some acts in churches and congregations, specifically in the context of the urban margins of Alagoas. The objective is to contribute to the comprehension of the evangelical religious experiences in the Northeast of the country. I propose the argument that the religious experiences and the criminal experiences tense up, interpenetrate and, consequently, imply in the way in which are enunciated the identifications: I am a criminal and I am evangelical, since this religiosity seems to work as moral mirror to the postures, performances and grammars.
\end{abstract}

Keywords: Religion; Crime; Margins; Interfaces.

\section{Introdução}

Tinha o evangelho debaixo da almofada. Pegou-o maquinalmente. Aquele livro era dela, pois era o mesmo em que lera o trecho da ressureição de Lázaro. Nos primeiros tempos do presídio pensava que ela iria importuná-lo com a religião e que se poria a falar do

\footnotetext{
"Mestre em Sociologia pela Universidade Federal de Alagoas (PPGS/UFAL), em que foi bolsista da Coordenação de Aperfeiçoamento Pessoal de Nivel Superior (CAPES); doutoranda em Sociologia pela Universidade de São Paulo (PPGS/USP); membro do Grupo de Pesquisa Periferias Afetos e Economia das Simbolizações (Gruppaes); Maceió, Alagoas, Brasil. E-mail:riziaada@gmail.com.
} 
Evangelho e a aborrecê-lo com o livreco. Mas, para o seu maior assombro, nem uma só vez ela the falou nisso, nem uma vez sequer lhe propôs o Evangelho. Foi ele quem the pediu, um pouco antes de ter adoecido, e ela o levou em silêncio. Até então, ele nem sequer o abrira. E também não o abriu naquele momento, mas ocorreu-lhe um pensamento: "A crença dela não poderia, naquele momento, ser a dele também? Pelo menos os seus sentimentos, as suas aspirações..." (...). Mas aqui já começa uma nova história, a história gradual da renovação de um homem, a história da sua transição progressiva de um mundo para outro, do seu contato com uma nova realidade, completamente ignorada até então (DOSTOIÉVSKI, 2007, p. 590).

Não são poucas as pesquisas que têm se debruçado sobre o evangelicalismo no Brasil e na América Latina, sobre o crescimento no número de fiéis das igrejas pentecostais e neopentecostais nos centros urbanos, interferindo no cenário simbólico, moral e político desta região (ANDRADE, 2009; BIRMAN, 2012; ALMEIDA, 2017; MARIANO, 2013). Além disso, também não são poucas as pesquisas que têm se debruçado sobre experiências de renovação de vida de indivíduos, mediadas por referências evangélicas. Chamo atenção em específico para as experiências de mobilização de uma gramática religiosa no crime, e para as experiências de conversão e desengajamento das redes criminaisa partir de atuações em igrejas e congregações. Como Birman (2019) sinaliza, tratam-se de pesquisas que partem de uma perspectiva critica, que permite entender os jogos de poder e as relações conflitivas que transitam entre o legal, o ilegal e o criminoso, com suas instabilidades e fluidez, indo além dos binarismos.

Entre as relevantes pesquisas socioantropológicas no campo da religião já realizadas, está a de Clara Mafra (2002). Embora a interface entre crime e religião não tenha sido uma preocupação central de seu trabalho, já no final dos anos 1990, a antropóloga apontava para como a religiosidade pentecostal - sobre a qual se debruçava a partir da experiência de expansão da Igreja Universal -, conformava um campo religioso menos rígido e aberto a experimentações, valorizando o conhecimento local imediatamente disponivel dos lugares onde se estabelecia, fosse para integrá-lo, fosse para se opor a ele, algo que Ricardo Mariano (2003) também tem apontado em relação às religiões pentecostais.

Ao tratar sobre as experiências de conversão, Mafra argumentou pela necessidade de se pensar sobre o espaço de interlocução, abertura e negociação entre sistemas simbólicos, que possibilitariam a convivência com as ambiguidades associadas às mudanças de comportamento no processo de conversão, tema 
que também é central para tantas outras pesquisas que, interessando de maneira particular à discussão aqui proposta, tratam sobre as experiências daqueles entendidos como bandidos.

A partir de distintas vivências de campo, tais pesquisas propõem diferentes maneiras de pensar a conversão religiosa: como um processo que promove a troca de mundos por meio do abandono da vida no crime e da adoção de outras práticas e valores (DIAS, 2015); como uma redefinição de fronteiras simbólicas, concedendo sentido às ações dos convertidos e senso de coerência para as situações vividas (SCHELIGA, 2005); como uma mudança de mundo e de pressupostos básicos por meio dos quais a identidade do indivíduo é compreendida (GUSMÃO, 2011); ou como a adoção da visão de mundo religiosa, substituindo "ethos de traficante" pelo "ethos de crente pentecostal" (TEIXEIRA, 2009).

O fato é que, conforme Birman (2012) continua a chamar atenção, a "cultura evangélica", há mais de uma década, vem tendo um alcance que ultrapassa as próprias igrejas e congregações. A interface evangélica pode ser observada no mundo da politica e da cultura, bem como, segundo demonstram as pesquisas mencionadas, no mundo do crime. Nesse sentido, em concordância com Marques (2013), acredito que seja necessário pensar para além das rupturas entre vivências e universos simbólicos, pensando as conversões como processos marcados por uma série de continuidades.

Mariana Côrtes (2005), por exemplo, relativiza os limites das "transformações radicais de vida" de indivíduos antes envolvidos com as práticas do crime e que aceitaram Jesus, tornando-se evangélicos e assumindo uma nova carreira, a de pregadores. Para ela, as rígidas fronteiras enunciadas por seus interlocutores entre ser evangélico e ser do crime são ressaltadas mais por um impacto estético e exterior do que por uma internalização profunda de novos valores morais, por uma tomada de consciência que implique em uma radical mudança na forma de conduzir a vida. É justamente esse tipo de ambiguidade que, a meu ver, cabe ainda ser problematizada, para além de se pensar na incompletude da experiência de conversão, mas pensando no relativismo apontado pela autora como um elemento da própria experiência religiosa, e, por isso mesmo, objeto de investigação.

Mais de dez anos passados, e pensando no contexto alagoano em particular, onde realizo pesquisa de campo, é preciso levar em consideração, por exem- 
plo, a lógica das facções, que hoje disputam o monopólio dos mercados e carreiras criminais e da nomeação do certo e do justono crime. Segundo apontam meus interlocutores, garotos e garotas que atuam nas redes do crime, entramados nos vínculos faccionais, a conversão religiosa muitas vezes se apresenta como uma alter-nativa legítima para aqueles que desejam abandonar a vida do crime. Assim como muitas regras de fundo religioso são mobilizadas no crime, para se decidir sobre o certo e o errado, e, em última instância, quem é irmão e quem pode receber punições.Isso porque o próprio evangelicalismo e o pentecostalismo conquistaram legitimidade entre os membros das facções, conforme se observa, também, nas cadeias e quebradas cariocas já há algum tempo(JOHNSON; DENSLEY, 2018).

É o que aponta Christina Vital da Cunha $(2014$; 2015) em sua pesquisa sobre a interface entre religião e criminalidade em uma favela carioca. A autora se debruçou sobre as carreiras de traficantes evangélicos desde os anos 1980, demonstrando como o evangelicalismo tem se adaptado e negociado perspectivas e práticas, possibilitando uma convivência relativa de universos simbólicos e, como Côrtes também aponta, relativizando as formas de ser evangélico. Como Cunha, também observo entre meus interlocutores que não há um modo único de experimentar a fé evangélica, assim como há várias formas de ser do crime. Há uma espécie de miscelânea nas formas de agir, ver e fazer o crime, inclusive mobilizando uma gramática religiosa, que pode envolver elementos morais e disciplinares que se interconectam.

Nesse sentido, as colocações de Marques (2013, 2019), a partir de sua etnografia, realizada nas periferias de São Paulo já dos anos de 2010, me parecem significativas. Ele argumenta que as irmandades do Primeiro Comando da Capital (PCC) e da fé se encontram nas performances e questões cotidianas de quem as vivencia, de modo que tais interfaces possibilitam os trânsitos entre os universos religioso e do crime. Ele demonstra como as igrejas pentecostais, presentes no cotidiano das comunidades por ele pesquisadas, dão significado às formas de ser viver e entender o mundo, excedendo as experiências do templo religioso.

Conforme também tenho considerado no contexto alagoano, Marques aponta para como irmãos do PCC e irmãos pentecostais atuam em espaços de empreendimento moral, buscando a regulação e rearranjo de sentidos e moralidades, algo por ele observado em seu campo desde os anos 1990. De maneira signi- 
ficativa, Marques argumenta, assim como Birman, pela necessidade de superação dos binarismos na compreensão do campo religioso pentecostal, para que se entendam as experiências, os modos de ser e de viver, de seus interlocutores, que atuam nas redes de igrejas e do PCC nas quebradas da fé.

É o que faz Ana Beraldo Carvalho (2020), em sua etnografia em um morro belo-horizontino, ao demonstrar a articulação normativa entre estado, crime e religião, que baliza as sociabilidades naquele território - como também acontece em outras periferias brasileiras e latino-americanas -, definindo, em última instância, os distintos níveis de precariedade de vidas nesses territórios. As normatividades, segundo a socióloga, são negociadas e disputadas situacionalmente no dia a dia das favelas. As igrejas de maneira particular desfrutam de uma legitimidade quase inquestionada no morro onde realizou pesquisa. Legitimidade sustentada tanto pela conversão de bandidos, como pela figura, também observada por Cunha, dos traficantes evangélicos. Como Côrtes, Carvalho defende o afrouxamento das fronteiras entre os universos simbólicos, possibilitada pela capacidade dos indivíduos de se moverem por entre as redes de engajamento, conforme também aponta Marques.

Considerando as questões suscitadas por tais pesquisas e tomando de empréstimo as noções de articulações, continuidades e interfaces nas experiências religiosas daqueles que estão na vida do crime, considero que há, ainda, questões a serem colocadas no contexto alagoano de hoje. As questões passiveis de serem refeitas em Alagoas e, eu diria, em outros estados do Nordeste do país, carecem de explicações que avancem nas descobertas já feitas em outros situações espaço-temporais. A conformação da religiosidade, as dinâmicas sociourbanas, as políticas criminais e a expansão dos mercados ilegais, embora evidentemente estejam articuladas e interconectadas país afora, assumem contornos distintos em contextos distintos.

Em outras palavras, apesar da extensa agenda de pesquisa já existente, é menor o conhecimento sobre as experiências nordestinas do Brasil, sobre como as igrejas formam "uma teia de tensões costuradas pelos investimentos afetivos das pessoas" (Rodrigues, 2020a, p. 4), servindo como uma espécie de espelho moral para as posturas, performances e gramáticas inclusive no mundo docrime 2 e nas redes criminais mais ao Nordeste do país. Neste artigo, então, procuro ensaiar algumas reflexões, ainda iniciais, sobre as fronteiras e interfaces entre reli- 
gião evangélica e crime, por meio das experiências religiosas daqueles que se encontram às margens urbanas de Alagoas, estado de urbanização bastante recente, que possui um dos piores índices de desenvolvimento humano do país e elevados índices de homicídios, ${ }^{3}$ características vivenciadas de maneira profunda por aqueles que estão em suas periferias urbanas, onde tenho procurado me concentrar.

Por meio do diálogo com as trajetórias e experiências ${ }^{4}$ de dois interlocutores, Madá e Efraim, por mim entrevistados enquanto cumpriam medida de privação de liberdade em unidades de internação, ensaio algumas reflexões sobre como, embora eles enunciem rígidas fronteiras entre serevangélico e serdo crime, a disposição de ambos para a experimentação religiosa aponta para a miríade de cursos e granulações que suas vidas podem tomar a partir dessas e de outras experiências que se interconectam. Eu diria que as fronteiras por eles enunciadas são muito mais tensas, negociadas e deslocáveis do que rígidas (SIMMEL, 2010). Estou pensando em encontros, assimilações, negociações e permanências, na mediação de uma "trama complexa e longa que conta com possiveis continuidades simbólicas" (TEIXEIRA, 2009, p. 106), nas interfaces entre crime e religião (JOHNSON; DENSLEY, 2018; MARQUES, 2013).

Em outras palavras, argumento que as experiências religiosas e do crime se tensionam, interpenetram, e, consequentemente, implicam na forma como são enunciadas as identificações: sou do crime e sou evangélico/a. Proponho que, em Alagoas, como já vem sendo apontado em outras pesquisas no país, as práticas disciplinares e os repertórios morais do crime e das facções são atravessados por referências religiosas evangélicas. Assim, ainda que um indivíduo não se identifique como evangélico, suas posições, gramática e performances se enunciam a partir de um diálogo com o arcabouço religioso, como demonstrarei a partir de Efraim. Em outros casos, tais continuidades e alinhavares podem desembocar em uma disposição para a conversão religiosa, como o caso de Madá, semelhantemente ao de Raskólnikov de Dostoiévski, parece apontar.

Embora, como afirmei inicialmente, tal hipótese não seja necessariamente uma novidade na bibliografia socioantropológica, minha principal intenção é trazer pistas sobre como tais experiências se dão entre jovens garotos e garotas alagoanos, que vivem nas margens urbanas. Procuro apontar para como os mais recentes fenômenos de expansão das redes faccionais, bem como do rompimento 
de uma aliança entre o Primeiro Comando da Capital (PCC) e Comando Vermelho $(\mathrm{CV})$, passaram a pressionar em diversos niveis as trajetórias desses jovens, e como a expansão de tais redes criminais passou a ser adaptada e mobilizada ao contexto local, considerando, inclusive, as experiências religiosas que, ao que me parece, atravessam as performances e a mobilização de regras no crime (BARROS et. al., 2018; MANSO; DIAS, 2017; RODRIGUES, 2020a, 2020b; SIQUEIRA; PAIVA, 2019).

Em Alagoas, até alguns anos, o mercado do tráfico funcionava de maneira dispersa, e cada região tinha sua própria dinâmica de conflitos e justiça. Foi em meados de 2016 que passei a ouvir com regularidade de muitos de meus interlocutores sobre suas adesões a alianças faccionais oriundas do Sudeste do país, a afeição pelos símbolos PCC ou CV. Nesse momento, se desenrolavam mudanças no cenário do crime alagoano, relacionadas às continuas politicas governamentais de endurecimento policial e penal, que já vinham acontecendo há alguns anos, e relacionadas à irrupção de uma abrupta rivalidade entre as duas facções, pela hegemonia na distribuição de mercadorias ilícitas, pela nomeação do certo e do errado e pelo controle de territórios.

No Norte e Nordeste, esse último evento viria a ficar conhecido como a guerra entre facções. A particularidade dessa figuração é um elemento que precisa ser considerado enquanto parte do jogo de relações que influencia nos movimentos, nas cadeias de tensão e pressão, das periferias alagoanas, e nos cursos da vida de muitos jovens que aqui vivem (CARVALHO, 2021; CARVALHO; SANTOS, 2021; RODRIGUES; SILVA; SANTOS, 2020; RODRIGUES, 2020a, 2020b).

\section{Hoje eu posso dizer que nada valeu a pena: alguns vestigios da trajetória de Madá}

Conheci Madá em janeiro de 2019, quando a entrevistei em uma unidade de internação, onde ela cumpria medida de privação e liberdade. ${ }^{5} \mathrm{O}$ diálogo continuaria nos meses seguintes, desvelando uma série de facetas de sua vida ainda desconhecidas. Madá tinha a cor negra e quase a mesma altura que eu, ou seja, não deveria passar de um metro e cinquenta e cinco. O cabelo comprido passava por transição capilar: havia dias em que o usava solto e exibindo os cachos que começavam a se formar; em outros, usava coberto com uma touca; em outros ainda, usava exibindo dreadlocks coloridos. Às vezes, a expressão séria aparentava distância. Talvez pela intensidade do que viveu, a garota parecia ter mais do 
que seus 19 anos. Quando começava a falar, no entanto, um sorriso largo se espalhava pelo rosto.

A garota considerava como pais a mãe e o avô materno, nutrindo um forte ressentimento em relação ao pai e à avó paterna, que nunca a reconheceram: eu nunca quis me aproximar dele. Quando eu descobri que ele num tinha me registrado, e... A minha vó tinha dito, a mãe dele, né, tinha dito que, se ele me registrasse, esquecesse que ela era a mãe dele. Aí, eu peguei ódio dos dois (sic). Aos nove anos, Madá perdeu o avô, que, além de prover a casa com o que vendia como feirante, era quem por ela tinha muito afeto: Depoi que eu perdi meu vô... Fiquei meia, sem querer saber de nada. (...) Oxe, eu acho que... Eu era... A netinha mais preferida do meu vô. Acho que ele me amava (sic).

Após a morte do avô, a garota narra que começou a se interessar por novas experiências. Começou gazeando 6 aulas para cheirar cola de sapateiro no Centro de Maceió. Em seguida, experimentou maconha e cigarro, entre outras drogas. Aos onze anos, ela continua narrando: eu saí da casa da minha mãe porque eu queria usar droga e ela num aceitava. Aí... Primeiro eu conheci o mundo da droga, ai, depois eu me envolvi no tráfico (sic). Madá foi morar com o primeiro marido, que tinha dezenove anos de idade.

O então marido - de quem ela viria a se separar e que foi posteriormente assassinado - atuava nas redes de tráfico em seu bairro. Assim, a garota se aproximou tanto do tráfico, quanto da facção. Em nossos diálogos, ela costumava falar sobre a posição que foi ocupando em sua quebrada. O segundo marido,com quem ainda mantinha um relacionamento quando a conheci, preso no sistema prisional, seria uma espécie de "liderança" da facção no lugar onde viviam, e ela também tinha uma posição prestigiosa. Contava histórias sobre cobranças, ataques a quebradas de rivais e missões. ${ }^{7}$ Madá corria com o Comando Vermelho.

Em algumas ocasiões, a garota falou com tom de pesar sobre as violências vividas enquanto estava no mundão, sobre os arrependimentos que a vida do crime lhe trazia. Nesses momentos, enunciar sua experiência religiosa parecia dotar de sentido as vivências que causavam dor, semelhantemente ao que outras pesquisas em ambientes de encarceramento e que tratam sobre experiências de conversão têm apontado (DIAS, 2008; GUSMÃO, 2011; SCHELIGA, 2005; TEIXEIRA, 2009). Era co-mo se, a partir de uma nova forma de conduzir a vida, novas escolhas, nova maneira de pensar, ela pudesse perceber com maior clareza seus erros, e como gostaria de conduzir sua trajetória dali em diante. 
Também, porque, quando você se envolve no tráfico, em questão de guerra, assim, de facção, quando a gente se envolve no tráfico, o patrão da gente só traficar e não ser da facção, isso não quer dizer nada. Porque você tá no tráfico, você tá colaborando, botando dinheiro pros cabeça comprar munição, comprar arma, pra ir de ataque a outra pessoa, da outra facção, entendeu? $E$, assim, desde muito cedo eu soube dessas coisa, fiquei com medo de tudo, pelo fato de eu ter em envolvido cedo, entendeu? E na época que eu me envolvi tinha umas confusão, mas não era na rua, era no sistema prisional. Era módulo A e módulo B, era tudo módulo, e tinha divisão, tinha cara junto, mas tinha divisão no módulo. E, aí, arcou em rebelião no [presídio alagoano], mas, até então, eu tava na rua, e na rua tinha os cara que mandava o salve, e, aí, eu fui me envolvendo, e outras pessoas que tava na rua, e, ai, eu fui ganhando, se eu saisse, eu era... entendeu? Por isso. Eu me envolvi muito, e, assim, hoje eu posso dizer que nada valeu a pena, e não aconselho a ninguém a fazer isso, porque, no mundo, a gente deve ganhar amigo, não inimigo, porque, quando você pensa que tá tranquilo, os seus inimigo vem de encontro a você, e só tem uma forma de você num se abalar, em Deus (sic). (Madá, março de 2020)

Como Madá e Efraim, que apresentarei adiante, tantos outros garotos e garotas com quem pude dialogar em unidades de internação têm em comum uma série experiências vivenciadas. Além de morarem em periferias urbanas, compartilham o abandono da escola e as aproximações geracionais com o mundo rural, decorrente do êxodo rural e da urbanização recente do estado, que se intensificou sobretudo nos anos 1990. Outra característica comum entre eles é o fato de terem pais substitutos como seus responsáveis material e afetivamente. São avós, avôs, tias, irmãs... que viraram mãe e pai, devido a experiências de fraturas familiares. ${ }^{8}$

Além disso, desde aproximadamente 2016, quando passou a ser enunciada uma guerra entre facções no Norte e Nordeste do país, entre garotos e garotos como Madá e Efraim, tornou-se urgente afirmar vínculos com facções como uma forma de exercer justiça, de colocar disciplina na quebrada e de se proteger de ameaças (RODRIGUES; SILVA; SANTOS, 2020; SANTOS, 2018; CARVALHO, 2018, 2021). Por fim, muitos deles compartilham, ainda, a disposição para a experimentação religiosa, e uma trajetória prévia de frequência em igrejas e congregações, como continuarei a desdobrar a seguir.

\section{Voltar frequentar a igreja pode, num pode ser evangélico: alguns vestigios da trajetória de Efraim}


Apresento, então, Efraim. Quando o conheci, em 2020, ele tinha 18 anos de idade. Como tantos garotos que já vi no sistema, tinha um corpo magro e baixa estatura, era um pouco maior que meu metro e meio. Sua pele tinha a cor branca e o cabelo liso estava sempre bem penteado. Falava baixo e firme, pouco sorria. Nasceu em uma importante cidade do agreste ${ }^{9}$ alagoano, distante mais de 100 quilômetros da capital.

Por volta dos quatro anos de idade, Efraim se mudou junto aos avós que o criavam para outra cidade, menor e mais ao sul do estado, já próxima da divisa com Sergipe. Segundo ele, seu tio fora assassinado em uma cocó, ${ }^{10}$ provocando profundo sofrimento na avó. Eles foram morar em um sítio, provavelmente numa tentativa por parte dela de reconstruir a vida longe do lugar que lhe trazia a memória do sofrimento. Cabe ressaltar que, embora não tenha sabido precisar, pois era muito novo quando tudo ocorreu, o tio de Efraim era envolvido com o crime.

No sítio, a saúde da avó se agravou, ela recebeu o diagnóstico de depressão e precisou voltar à cidade de origem para ter acompanhamento médico mais adequado. Desde a infância, Efraim frequentava uma Assembleia de Deus, junto a toda a sua família (pais e avós). $\mathrm{Na}$ igreja, onde permaneceu até o começo da adolescência, ele participava do grupo de jovens. Cantava em um coral e até circulava por outras igrejas para cantar com o grupo.

Aos 15 anos de idade, Efraim começou a praticar os primeiros roubos. Quando o conheci, respondia pelas acusações de desmanche de veículos e interceptação, além de um homicídio. Na unidade e em sua quebrada, ele corria com o Primeiro Comando da Capital. Segundo o garoto, antes da territorialização do PCC e sua disciplina em sua quebrada, era muito desorganizado. A morte de seu tio parece se reportar a esse momento, em que o mercado do tráfico funcionava de maneira mais difusa e em que cada quebrada tinha sua própria dinâmica criminal e de conflitos. O momento em que Madá começou a se aproximar do tráfico, no começo dos anos 2010, também parece a se reportar a esse momento. Com a enunciação das facções, reduziram-se os "gradientes de descentralização da resolução de conflitos" entre aqueles envolvidos no mundo do crime (Rodrigues, 2020b, p. 2), mas nem por isso os conflitos se tornaram menos violentos.

Efraim explicou que, no mesmo período em que passou atuar nas redes do crime em sua quebrada,por volta dos 15 anos, também se afastou dos vínculos com a igreja porque tava com negócio fora e dento, fora e dento, aquelas duas coisa, aí, quando a pessoa tá nesse mundo, se envolvendo, acaba se afastando das 
coisa de Deus ( $\mathrm{sic}$ ). Ele disse ainda gostar das atividades que desenvolvia na igreja. No entanto, num vou tá nas duas coisa, ou é uma coisa ou é outra (sic). Ao mesmo tempo, esboçou um desejo: um dia eu posso voltar, a ser o que eu era antes (sic).

\section{Crime e guerra em Alagoas}

Já entre os anos 1990 e 2000, existiam aproximações entre os mercados criminais alagoanos e as redes criminais oriundas do Sudeste do país, denominadas como facções: o Comando Vermelho, que chegou primeiro no estado, e, posteriormente, o Primeiro Comando da Capital. No entanto, foi em meados de 2016, quando realizava pesquisa de campo há cerca de um ano em unidades de internação, que passei a ouvir com regularidade de muitos dos jovens que entrevistávamos sobre suas adesões a essas redes. Eles falavam sobre afeições e aversões aos simbolos PCC ou CV (CARVALHO, 2021).

Isso se dava em um contexto em que politicas governamentais de segurança pública, já há alguns anos, vinham provocando um grande aumento no encarceramento e a maior circulação de presos pelo país. No caso de Alagoas especificamente, entre 2007 e 2012, o estado se destacou por, proporcionalmente, ter o maior aumento no aprisionamento de adolescentes entre as demais unidades da federação (BRASIL. Presidência da República. Secretaria Geral, 2015; FELTRAN, 2010; GODOI, 2016; GRILLO, 2019; HATHAZY, 2015; RODRIGUES, 2017).

Somando-se a isso, e é para esse evento que chamo atenção, aprofundavase a guerra entre o PCC e o CV, disputando, em cadeias e quebradas do Norte e Nordeste do país, os monopólios do fornecimento de mercadorias ilícitas e da nomeação do certo e errado(Barros et al., 2018; Lourenço; Almeida, 2013; Manso; Dias, 2017; Pires, 2018; Rodrigues, 2020a, 2020b). Tais eventos são cruciais para se compreenda o jogo de relações que influencia nos fluxos, tensões e pressões nas periferias alagoanas, e nos cursos da vida de jovens como Madá e Efraim (Carvalho, 2021).

Em concordância com Rodrigues, entendo que a enunciação das facções não necessariamente expressa o enraizamento de uma disciplina faccional em Alagoas, como uma tradição, mas expressa a ansiedade de jovens diante de uma novidade prestigiosa (RODRIGUES, 2020b), trazendo a atrativa possibilidade de "se firmar" no crime, gozando, entre outras coisas, de prestígio, poder aquisitivo e 
até de proteção (LIMA, 2016; RODRIGUES; SILVA; SANTOS, 2020). Na singularidade assumida pelos sensos de adesão às facções em Alagoas, ficam em questão antigas tradições de fidelidade, que continuam a impulsionar a estruturação do crime, embora sob novos atravessamentos afetivos e normativos (RODRIGUES, 2020b, p. 3 e 4).

Diante do cenário de guerra, desenvolveu-se um clima de instabilidade e de muitas desconfianças, em que ser - ou sair - da facção significa estar sob grande risco. No ano de 2019, por exemplo, segundo o Atlas da Violência, Alagoas permaneceu entre os estados brasileiros com maiores índices de homicídio de jovens, o que se repetiu em 2020. Em 2019, essa grande incidência de mortes no estado, e em outros das regiões Norte e Nordeste, foram associados, também, à guerra entre facções (IPEA; FBSP, 2019; IPEA, 2020).

Muitos de meus interlocutores passaram a falar na necessidade de mudarse de bairro ou até cidade, no rompimento de vínculos com amigos e familiares, no abandono da escola e de outros espaços por onde circulavam. Tudo isso para se proteger de ameaças de inimigos da facção rival, ou da própria facção a qual se vinculavam, diante de acusações de erros em suas caminhadas. ${ }^{11}$ Nas periferias urbanas de Alagoas, chegaram a acontecer movimentos de evacuações de famílias que se viram pressionadas pelo risco de ataques e cobranças (RODRIGUES, 2020b). Madá, por exemplo, mencionou ter deixado de frequentar a praia e os bailes de reggae, espaços que para ela eram de divertimento, porque ficou com medo de sofrer represálias: Eu só num tava indo agora por causa desses negócio de facção (sic).

Diante de tais circunstâncias, em casos como o de Madá, que dizia ocupar posição de "liderança" em sua quebrada, certamente fazendo muitos inimigos, a experiência religiosa parece funcionar como uma forma de ressignificar o passado e o futuro, conforme Scheliga (2005) e Dias (2008) apontam, e de se proteger de ameaças, como Cunha (2015) também sugere. Os diálogos com a garota continuam a ser elucidativos, e é sobre suas experiências religiosas e as de Efraim que continuo a refletir adiante:

Ada - É... Pesando no... Ele tinha como um buraquinho, né, um espaço lá vazio, que ele entendeu que tava faltando alguma coisa. $\mathrm{E}$, aí, quando a gente pensa na nossa vida, sempre falta alguma coisa, a gente sempre quer algo mais. E, aí, quais são as partes que hoje faltam na nossa vida?

Madá -Eu acho que eu sou cheia de buraco, mas... O principal, que eu consegui preencher. Tive maturidade suficiente pra preencher foi enxergar que Deus é tudo (sic). 
Ada- Pra quem falou dessas partezinhas que faltam, quando foi que a gente começou a perceber que "eita, poxa, isso tá me faltando..."?

Madá -Eu pensei lá fora. Porque eu acho assim, o pensamento só existiu aqui dento [na unidade de internação], né, lá fora a gente vivia pensando também, independente de tá privado ou não, num importa, a gente tem a liberdade mentalmente, a gente pode ir pra onde a gente quiser, ir pra casa, no pensamento. A gente tá privada de, de... Sair... E quando eu preenchi o vazio que eu necessitava ter, essa aliança com Deus, eu botei assim: que, em primeiro lugar, de tudo, de minha mãe, meus filho, de tudo, minha família, era Deus, porque, se eu num amar a Deus, eu num vou conseguir amar minha família (sic) (Roda de Conversa, junho de 2019).

\section{Madá, Efraim e as experiências religiosas}

O diálogo anterior se deu na metade da manhã de uma quinta-feira de junho de 2019. Nesse dia, por volta das 10 h00, realizei, junto a uma companheira de pesquisa, uma atividade de Roda de Conversa ${ }^{12}$ na unidade onde Madá cumpria medida socioeducativa. Refletindo de maneira analítica sobre essa atividade, entendo que a incorporação e a mobilização de maneiras de pensar, de sentir e de dizer eram adaptadas ao contexto das interações entre as adolescentes participantes, às posições de prestígio que ocupavam umas em relação às outras e às balanças de poder que pendiam de um lado a outro (LAHIRE, 2002). Ao responder e dialogar com as provocações que fazia, as garotas não se dirigiam apenas a mim, mas às expectativas e constrangimentos que exerciam entre si, e também aos funcionários da unidade, que nos observavam mais ou menos atentamente (CARVALHO, 2021).

É preciso salientar, ainda, que naquela unidade em específico havia algo de inusitado em relação às unidades de internação masculinas. Garotas que corriam $^{13}$ com diferentes grupos faccionais conviviam sem grandes conflitos no mesmo ambiente, ainda que diante do cenário de guerra vivenciado do lado de fora dos muros da unidade. Nas unidades de internação masculinas, garotos que corriam com o $\mathrm{CV}$, por exemplo, jamais poderiam dividir o mesmo espaço que os que corriam com o PCC. Seria agressão - ou até morte - certa. Na unidade feminina, no entanto, as garotas não apenas conviviam, mas chegam a construir vínculos de amizade nos alojamentos, ao dividir a condição de encarceradas (CARVALHO, SANTOS, 2021; RODRIGUES, 2020b).

Voltando à Roda de Conversa daquela manhã de quinta... Usávamos a biblioteca como espaço para nossos encontros. Uma sala pequena, de uns oito metros quadrados, parcamente mobiliada com três estantes cinzas e de metal, re- 
pletas de livros de literatura infanto-juvenil, de receitas, de direito, dicionários, almanaques etc., além de uma mesa de plástico branca e um ventilador barulhento preso na parede.

Com a ordem da monitora,vão entrando ai na sala, as cinco garotas com quem conversaria naquela semana chegaram, uma a uma, trazendo cadeiras de plástico da sala vizinha, onde assistiam um filme. Elas tinham uma faixa de idade que ficava entre 15 e 19 anos. Com exceção de uma, todas relatavam que, em algum momento de suas trajetórias, praticaram tráfico de drogas e roubos. Tais atividades interligavam suas trajetórias e suas quebradas a outros bairros, cidades, interiores e capitais do Brasil, por onde algumas delas chegaram a circular em negócios ilegais. Tais interconexões eram possíveis devido a suas vinculações com as redes criminais expressas nos simbolos CV e PCC.

Nesse dia em específico, lemos o livro infanto-juvenil: A parte que falta, de Shell Silverstein, que conta a história de uma bolinha "incompleta" que sai em busca de uma parte para preencher um espaço vazio que encontra em si. Eu conduzi a leitura, enquanto as garotas ouviam em silêncio, sem interagir. Finda a leitura, fiz algumas perguntas previamente elaboradas. Nesse contexto é que se deram as falas de Madá, transcritas anteriormente: Eu acho que eu sou cheia de buraco,mas...Oprincipal,que eu consegui preencher. Tive maturidade suficiente pra preencher foi enxergar que Deus é tudo (sic).

Como já havia ocorrido antes, a garota enfatizava sua disposição para experiência religiosa e para sair da vida do crime. Ambivalentemente, ao mesmo tempo em que falava em arrependimento, era a mais empolgada entre as demais ao narrar suas "proezas" no crime. Desde a infância, ela circulou por missas em igreja católica, junto ao avô; e por cultos em igrejas evangélicas, levadas por conhecidas da mãe, que, segundo ela, nunca expressou disposição por aderir a alguma prática religiosa institucionalmente: ela gosta de escutar muito hino, mas ela nunca se definiu não (sic). Madá tinha, ainda, uma avó rezadeira, e chegou a frequentar um terreiro, embora em sua fala afastasse qualquer aproximação: eu nunca gostei não desses negócio, eu tenho medo (sic).

Batizada na igreja católica e na igreja evangélica, Madá frequentou apenas de maneira esparsa missas e cultos, embora se identificasse com a igreja evangélica, dizendo que era da Assembleia de Deus. Aos treze anos, no entanto, ela deixou definitivamente de frequentar a igreja, pelo seguinte motivo: eu achava que 
eu tava magoando Deus, né, que eu tá na igreja, era como se eu tivesse mangando de Deus, porque a apalavra de Deus diz que num pode matar, né, nem roubar, e eu já fiz isso tudo (sic).

Sua trajetória, nesse momento, se aproxima da trajetória de Efraim. Ambos narraram ter vivências em igrejas evangélicas desde a infância, se identificavam com a religião evangélica e frequentaram, mais ou menos intensamente, Assembleias de Deus em suas quebradas. Efraim, inclusive, parece ter tido uma trajetória de maior institucionalização em sua congregação. ${ }^{14}$

Em um dado momento da adolescência, por volta dos 15 anos, o garoto também deixou de frequentar sua igreja porque tava com negócio fora e dento, fora e dento ( $\mathrm{sic}$. Os dois se afastaram dos vínculos na igreja, enunciando como justificativa as fronteiras entre a vida do crime e a religião. É chamativo, no entanto, como nenhum dos dois tenha necessariamente deixado de expressar a disposição para a experimentação religiosa, o desejo de frequentar uma igreja, o desejo de voltar a ser o que era antes, sugerindo-me uma flexibilização em suas experiências religiosas, como se estas fossem moldadas a partir de suas próprias reflexões e necessidades (MARINHO, 2017).

Em outras palavras, embora Madá e Efraim enunciem rígidas fronteiras entre ser evangélico/ ser da igreja e ser do crime, suas trajetórias sugerem que há muito mais interpenetrações do que as ideias de uma coisa ou outra, mencionada por Efraim,aparentam. Parece haver uma espécie de esgarçamento das fronteiras que são enunciadas como rígidas, mas que demonstram ter flexibilizações (CUNHA, 2015; RIVERA, 2012). No caso específico de Madá, já na unidade de internação, ela explica: eu me envolvi muito, e, assim, hoje eu posso dizer que nada valeu a pena (...) e só tem uma forma de você num se abalar, em Deus (sic), sugerindo uma experiência de "conversão". Já Efraim, quando lhe perguntei se pretendia voltar a frequentar alguma igreja, mesmo que continuasse na vida do crime quando saísse da medida de internação, explicou o seguinte:

Ada - E pode frequentar igreja, alguma coisa assim?

Efraim- Pode. Primeiramente a Deus. Tudo que vier ali que for da parte de Deus, evangelização, a gente respeita, a qualquer momento (sic).

Ada - Cê pensa em procurar uma igreja, ou num quer mais isso pra você?

Efraim -Penso. Num sei, assim, né... mas eu penso de voltar pra $i$ greja (sic). 
Ada - Mas você pensa assim: só posso voltar pra igreja quando sair do crime, ou pode ir pra igreja ao mesmo tempo?

Efraim -Voltar frequentar a igreja pode, num pode ser evangélico (sic)...

Ada - Então, hoje você considera que não é evangélico?

Efraim -Não. Que eu num vou tá nas duas coisa, ou é uma coisa ou é outra (sic)(Efraim, março de 2020).

A partir do diálogo com os dois jovens, é possivel perceber como contexto de guerra entre facções, acrescentou algumas camadas de vulnerabilidade às vidas daqueles que estão nas margens urbanas. Como contextualizei na sessão anterior, a guerra potencializou um ambiente incerto e tenso nas quebradas, um ambiente de desconfianças, em que sair da facção e sair do crime nunca é fácil, mas extremamente tenso, arriscado e negociado. Pressionados a assumir um lado na guerra, muitos garotos e garotas falam em virar evangélicos/as como uma alternativa à vida do crime:

Ada - Então, normalmente, quando uma pessoa sai do crime, ela vira evangélico? Ou não necessariamente?

Adolescente $-D a$ parte dos integrante [irmãos da facção] ali, eu num sei responder não. Se for pá virar evangélico ali, né, virar trabalhador. Da nossa parte ladolescentes, que não são irmãos, mas correm com a facção], eu sei responder: é. Livre-arbitrio. Nóis faz o que quer, só num pode fechar com outa facção, se fechar com outa facção, nóis vira inimigo (sic).

(Garoto em unidade de internação masculina, março de 2020)

Ada - E quem não quer correr com a facção, que diz assim, "não quero mais"?

Adolescente - Quem corre e não quer mais correr? Tem saída, só que, se sair, ou vai sair pra virar evangélico ou não se envolver mais com o crime (sic).

(Garoto em unidade de internação masculina, março de 2020)

Ada - Onde vocês acham que ainda podem melhorar?

Adolescente -Eu posso melhorar ali de virar evangélico, né, e ir pro céu, mudar de vida (sic).

(Garoto em unidade de internação masculina, março de 2020)

Para que tal desengajamento seja considerado válido, no entanto, é necessário enunciar e performar uma conversão que se torne visível por meio da distinção comportamental e estética, que se opõe àquilo que se entende por mundo do crime (CUNHA, 2015; DENSLEY; PYROOZ, 2019; JOHNSON; DENSLEY, 2018; GUSMÃO, 2011). Como afirma Misse (2010, p. 30), "não basta que haja conversão, é necessário dar-lhe o testemunho público".

Assim, por mais que na unidade feminina o conflito entre facções não parecesse interferir tanto nas relações entre as garotas, não se poderia esquecer 
que em algum momento elas sairiam dali, voltariam às suas quebradas, prestariam contas de seus atos. Talvez, amizades ali surgidas não pudessem ter continuidade no mundão. Do lado de fora, elas voltariam a se posicionar nas rígidas fronteiras de aliadas ou rivais. Em tais circunstâncias, as falas de Madá sobre as partes que lhe faltavam poderiam estar sendo dirigidas às demais garotas como uma maneira de já apontar um afastamento da vida do crime, como uma forma de legitimar as escolhas que então fazia, apontando para uma mudança de vida. Naquela figuração, entendida através da teoria eliasiana (Elias, 1980), as garotas exerciam mútuas pressões e constrangimentos umas sobres as outras, mesmo que, devido às suas posições no mundão, algumas estivessem em desvantagem nas balanças de poder.

A partir de tais trajetórias e diálogos, levanto algumas hipóteses prospectivas para pensar interpretativamente sobre os cursos e efeitos nas trajetórias de Madá e Efraim. Quais seriam, então, as alternativas disponiveis aos dois, considerando o contexto alagoano já apresentado e suas enunciações prospectivas? A partir das trajetórias de tantos outros adolescentes com quem já pude dialogar, aponto algumas possibilidades, pensando nas distinções entre as possíveis experiências de ambos.

No caso de Madá, é possivel que, ao receber a liberdade, ela volte a frequentar a igreja Assembleia de Deus em sua quebrada. Possivelmente, ao engajar-se em vínculos com os membros da igreja, seja possivel para a garota migrar para outra cidade ou até estado, uma vez que seria arriscado permanecer em Maceió. No entanto, reduzir sua experiência e engajamento religioso a uma resposta às dificuldades e riscos enfrentados não seria suficiente, afinal, como ela mesma narrou, mesmo quando estava na vida do crime, apresentava a disposição para a experimentação religiosa, lá fora a gente vivia pensando também (sic), sugerindo-me justamente o que tenho entendido como interfaces e interpenetrações entre seu arcabouço religioso e a vida no crime.

Além disso, virar evangélico/a e engajar-se em uma igreja só se torna uma alternativa viável porque é legitimada pelos membros da facção, pelo crime. Ou seja, engajamento nas redes da religião parece ser anterior aos cursos que sua vida pode tomar daí em diante, e, a meu ver, pode ampliar suas possibilidades de rumos (ALENCAR, 2012; JOHNSON; DENSLEY, 2018).

É da articulação entre espaços, tempos, pessoas e experiências que se cria uma comunidade, uma igreja, como espelho da região moral ao qual tais indiví- 
duos são assimilados e da qual são testemunhos. Começar a, de fato, frequentar uma igreja acontece em um contexto de sociabilidade, no encontro de laços afetivos (BIRMAN; MACHADO, 2012; FOERSTER, 2012). Nesse sentido, também é provável que Efraim volte a frequentar a igreja de sua infância, também Assembleia de Deus. Em seu caso, no entanto, é possível que não haja o interesse de estabelecer vínculos, ou ser reconhecido institucionalmente: Voltar frequentar a igreja pode, num pode ser evangélico (sic). Uma série de pesquisas têm apontado para o que também percebo, ainda de maneira inicial, entre meus interlocutores: individuos inseridos nas "malhas do crime" têm passado a articular uma "gramática pentecostal”, alinhavando visões morais de certo e errado em suas relações e práticas, como me parece ser o caso de Efraim (Cunha, 2015).

Nessas circunstâncias, assim como para Madá estar vinculada institucionalmente a uma igreja lhe serviria como uma rede de proteção (CUNHA, 2015), o PCC também poderia ter a mesma função para Efraim (RODRIGUES; SILVA; SANTOS, 2020). Por outro lado, é possível que o garoto esteja mais vulnerável tanto a cobranças do mundo do crime, quanto a uma apreensão, indo parar no sistema prisional.

Contrapõem-se aqui duas possibilidades, que embora tenham interfaces, também têm suas fronteiras. No caso de Madá, caso se engaje em uma igreja e passe a seguir suas diretrizes, será o fim da vida de aventuras, adrenalina e prestígio. Sua trajetória, ao que me parece, mais se aproxima do jovem Raskólnikov, de Dostoiévski, que, diante do remorso pelo crime cometido e do sofrimento da prisão na Sibéria, se sente atraído pela remissão pela via religiosa, pela religião na qual havia sido formado desde a infância. No caso de Efraim, ele parece encarar outra possibilidade: O que eu tenho na minha mente é que todo mundo nasce pra morrer. Cedo ou tarde eu vou morrer, então, o que tiver de fazer eu vou fazer, num vou tentar agradar os outo (sic).

Evidentemente, essas são apenas duas suposições extremas. As posições de Madá e Efraim estão entre duas fronteiras, que podem ser deslocadas e transcendidas, afinal, os cursos e intercursos da vida são imprevisíveis e múltiplos, e não necessariamente dependem única e exclusivamente de suas vontades (Simmel, 2010). É interessante perceber, no entanto, como no caso de ambos, a dimensão religiosa, é um elemento central de suas experiências, como se identificam e como interpretam os cursos de suas vidas. 


\section{Algumas (in)conclusões finais}

Por meio de alguns vestígios das trajetórias e diálogos com os adolescentes Madá e Efraim, procurei apontar para como, apesar de ambos enunciarem rígidas fronteiras entre serevangélico e serdo crime, eles também demonstraram a disposição para a experimentação religiosa. Suas falas dão algumas pistas para se pensar sobre as interfaces entre esses dois universos a partir da multiplicidade de cursos de suas vidas e experiências. Estou propondo que as fronteiras por eles enunciadas são muito mais porosas do que rígidas, sugerindo existir encontros, assimilações, negociações e permanências na mediação de uma "trama complexa e longa que conta com possiveis continuidades simbólicas" (TEIXEIRA, 2009, p. 106). São o que estou entendendo como interpenetrações nas vivências entre o crime e a religião, mais especificamente evangélica (JOHNSON; DENSLEY, 2018; MARQUES, 2013).

Em sua tese de doutorado, Carvalho (2020) também aponta para como nas periferias mineiras coexistem os regimes normativos do crime e religioso, fazendo interagir lógicas moralmente informadas que organizam e regulam as sociabilidades entre os individuos. A autora aponta para como as igrejas têm uma legitimidade quase inquestionada no território onde fez pesquisa, talvez pela capacidade de conectar-se ao divino em um contexto adverso, fornecendo a possibilidade de salvação para aqueles que se encontram em posição de vulnerabilidade. $\mathrm{E}$, ainda que as igrejas se coloquem em oposição ao crime, os regimes normativos se articulam, seja por meio da conversão de bandidos, como parece ser o caso de Madá, seja por meio da figura do traficante evangélico, como parece ser o caso de Efraim, semelhante ao que Cunha (2015) aponta na realidade carioca.

As trajetórias desses dois interlocutores, no entanto, exigem um esforço por contextualizar as especificidades do contexto nordestino, particularmente alagoano, ainda carecendo de maior aprofundamento. Argumento que jovens como Madá e Efraim, expostos às espirais de violência intensificadas pelos conflitos entre facções demandam redes de proteção, que podem ser encontradas na própria facção, na família ou em congregações e igrejas (CARVALHO, 2021; RODRIGUES; SILVA; SANTOS, 2020). Entendo, no entanto, que ainda é preciso um mergulho mais profundo sobre como a religião evangélica tem balizado sociabilidades, comportamentos, hierarquizações sociais e autoidentificações nas margens urbanas alagoanas, fornecendo sensos morais e de justiça inclusive no crime (CARVALHO, 2020). 
Como fica claro, existem mais questões a serem respondidas do que respostas e conclusões. A partir de minhas iniciais incursões em campo, tenho buscado, então, lidar com as seguintes perguntas: Por que ser evangélico é enunciado como uma alternativa para quem quer sair do mundo do crime, como apontou Madá? Por que muitos de meus interlocutores, ainda que afirmem estar na vida do crime, mobilizam uma gramática religiosa e expressam a disposição para a experimentação religiosa, até por frequentar uma igreja, por exemplo, como sugeriu Efraim?Ao que me parece, no entanto, tais perguntas já apontam para as interfaces entre a religião e o crime nas periferias urbanas alagoanas, que, a meu ver, podem ser entendidas por meio das ressonâncias morais e disciplinares.

Apesar do muito que já tenha se dito sobre tal temática, sobretudo no eixo Rio-São Paulo, algumas questões ainda precisam ser recolocadas mais de vinte anos depois. A centralidade dessas questões volta a me remeter aos achados de Mafra, que, ainda nos anos 1990, forneceu pistas sobre o fenômeno de expansão das religiões evangélicas e pentecostais, apontando não apenas para mudanças configuracionais na vida das periferias urbanas (SANTOS, 2017), mas, principalmente, para a percepção de como aqueles que estavam às margens dos países periféricos passaram a assumir centralidade na expansão dessa vertente religiosa, a ponto de disputar espaço, inclusive, nos países ditos centrais. Tais percepções demonstram a relevância de pesquisas que continuem a se debruçar sobre a expansão da religião evangélica por outros territórios brasileiros na contemporaneidade, abarcando distintos marcadores, inclusive os geracionais, como procurei fazer por meio dos diálogos com Madá e Efraim.

\section{Referências bibliográficas}

ALENCAR, Gedeon Freire. Assembleias Brasileiras de Deus: Teorização, história e tipologia -1911-2011. São Paulo: Pontificia Universidade Católica de São Paulo, 2012.

ALMEIDA, Ronaldo. A onda quebrada - Evangélicos e conservadorismo. Cadernos Pagu. São Paulo: Unicamp, v. 50, 2017.

ANDRADE, Maristela Oliveira de. A Religiosidade Brasileira: O pluralismo religioso, a diversidade de crenças e o processo sincrético. Revista Brasileira de Ciências Sociais. São Paulo: ANPOCS, n. 14, 2009. p. 106-118.

BARROS,JoãoPauloPereiraet.al."Pacificação" nas periferias: Discursos sobre as violências e o cotidiano de juventudes em Fortaleza. Revista de Psicologia. Fortaleza: UFC, v. 9, n. 1, 2018. p. 117-128.

BIRMAN, Patrícia. Cruzadas pela paz: Práticas religiosas e projetos seculares re- 
lacionados à questão da violência no Rio de Janeiro. Religião \& Sociedade. Rio de Janeiro: ISER, v. 32, n. 1, 2012. p. 209-226.

BIRMAN, Patrícia. Narrativas seculares e religiosas sobre a violência: As fronteiras do humano no governo dos pobres. Sociologia \& Antropologia. Rio de Janeiro: UFRJ, v. 9, n. 1, 2019. p. 111-134.

BIRMAN, Patrícia; MACHADO, Carly. A violência dos justos: Evangélicos, mídia e periferias da metrópole. Revista Brasileira de Ciências Sociais. São Paulo: ANPOCS, v. 27, n. 80, 2012. p. 55-69.

BRASIL. Presidência da República. Secretaria Geral. Mapa do encarceramento: Os jovens do Brasil. Brasília: Presidência da República, 2015. Disponível em https:// nacoesunidas.org/wp-

content/uploads/2018/01/Mapa_do_Encarceramento_-

_Os_jovens_do_brasil.pdf.

CARVALHO, Ana Beraldo. Negociando a vida e a morte: estado, igreja e crime em uma favela de Belo Horizonte. Tese (Doutorado em Sociologia). São Carlos: UFSCar, 2020.

CARVALHO, Ada Rízia Barbosa de. A “máquina opressora”: A gestão da vida de adolescentes sentenciados a cumprir medida socioeducativa em unidades de internação de Alagoas. Trabalho de Conclusão de Curso (Bacharelado em Ciências Sociais). Maceió: UFAL, 2018.

CARVALHO, Ada Rízia Barbosa de. Cadeias de tensão:Repertórios disciplinares de facções e do sistema em unidades de internação alagoanas. Dissertação (Mestrado em Sociologia). Maceió: UFAL, 2021.

CARVALHO, Ada Rízia Barbosa de; SANTOS, Alana Barros. Algumas expressões da guerra entre facções nas unidades de internação alagoanas. Áskesis. São Carlos: UFSCar, v.9, n.1, 2020.p. 19-35.

CÔRTES, Mariana Magalhães Pinto. O bandido que virou pregador. A conversão de criminosos ao pentecostalismo e suas carreiras de pregadores. Tese (Doutorado em Sociologia). São Paulo: USP, 2005.

CUNHA, Christina Vital da. Oração de Traficante: Uma etnografia. Rio de Janeiro: Garamond, 2015.

DENSLEY, James; PYROOZ, David C. A Signaling Perspective on Disengagement from Gangs. Justice Quarterly, v. 36, n. 1, 2019. p. 31-58.

DIAS. Camila Caldeira Nunes. A igreja como refúgio e a bíblia como esconderijo: Religião e violência na prisão. São Paulo: Humanitas, 2008.

DOSTOIÉVSKI, Fiódor. Crime e castigo. Porto Alegre: L\&PM, 2014.

ELIAS, Norbert. Introdução à sociologia. Lisboa: Edições 70, 1980.

FELTRAN, Gabriel. Crime e castigo na cidade: Os repertórios da justiça e a questão do homicídio nas periferias de São Paulo. Caderno Centro de Recursos Humanos. Salvador: UFBA, v. 23, n. 58, 2010. p. 59-73. 
GODOI, Rafael. Penar em São Paulo: Sofrimento e mobilização na prisão contemporânea. Revista Brasileira de Ciências Sociais. São Paulo: ANPOCS, v. 31, n. 92, 2016.

GRILLO, Carolina Cristoph. Da violência urbana à guerra: Repensando a sociabilidade violenta. Dilemas - Revista de Estudos de Conflito e Controle Social. Rio de Janeiro: UFRJ, v. 12, n. 1, 2019. p. 62-92.

GUSMÃO, Eeduardo Henrique Aaraújo. Dinâmicas prisionais e religião: Uma análise sobre as trajetórias e experiências de detentos em processos de conversão. Tese (Doutorado em Antropologia). Recife: UFPE, 2011.

HATHAZY, Paul. The rebirth of the prison in Latin America: Determinants, regimes and social effects. Crime, Law and Social Change, v. 65, n. 3, 2015. p. 113135

IPEA. FBSP. Atlas de violência 2019. Brasília: Rio de Janeiro: São Paulo: Instituto de Pesquisa Econômica Aplicada; Fórum Brasileiro de Segurança Pública, 2019. Disponivel emhttps://www.ipea.gov.br/atlasviolencia/download/19/atlas-daviolencia-2019. Acesso em 31 de outubro de 2020.

IPEA. Atlas da violência 2020. Brasília: Instituto de Pesquisa Econômica Aplicada. $2020 . \quad$ Disponivel em https://www.ipea.gov.br/atlasviolencia/download/24/atlas-da-violencia-2020. Acesso em 15 de fevereiro de 2021.

IPEA, PNUD. Atlas do Desenvolvimento Humano do Brasil, 2017. Disponivel http://www.leffa.pro.br/textos/abnt/internet.html. Acesso em 21 de marçode 2021.

JOHNSON, Andrew; DENSLEY, James. Rio's new social order: How religion signals disengagement from prison gangs. Qualitative Sociology, v. 41, n. 2, 2018. p. 243-262.

LAHIRE, Bernard. Homem plural: Os determinantes da ação. Petrópolis: Vozes, 2002.

LIMA, Carla Patrícia Siqueira. As mulheres nas redes do tráfico de drogas em Alagoas. Dissertação (Mestrado em Sociologia). Maceió: UFAL, 2016.

LOURENÇO, Luiz Cláudio; ALMEIDA, Odilza Lines. "Quem mantém a ordem, quem cria desordem": Gangues prisionais na Bahia. Tempo Social. São Paulo: USP, v. 25, n. 1, 2013. p. 37-59.

LYRA, D. A república dos meninos: Juventude, tráfico e virtude. Rio de Janeiro: Mauad X: Faperj, 2013.

MALLART, Fábio. Cadeias dominadas: Dinâmicas de uma instituição em trajetórias de jovens internos. Dissertação (Mestrado em Antropologia). São Paulo: USP, 2011.

MANSO, Bruno Paes; DIAS, Camila Caldeira. PCC, sistema prisional e gestão do novo mundo do crime no Brasil. Revista Brasileira de Segurança Pública. São Paulo: Fórum Brasileiro de Segurança Pública, v. 11, n. 2, 2017. p. 10-29. 
MARIANO, Ricardo. Mudanças no campo religioso brasileiro no Censo 2010. Debates do NER. Porto Alegre: UFRGS, v. 2, n. 24, 2013. p. 119-137.

MARINHO, Noélia Nunes. A experiência de ser jovem e mulher em uma igreja tradicional protestate. Dissertação (Mestrado em Sociologia). Maceió: UFAL, 2017.

MARQUES, Vagner Aparecido. O irmão que virou irmão:Rupturas e permanências na conversão de membros do PCC ao pentecostalismo na Vila Leste -SP. Dissertação (Mestrado em Ciências da Religião). São Paulo: PUC-SP, 2013.

MISSE, Michel. Crime, sujeito e sujeição criminal: Aspectos de uma contribuição analitica sobre a categoria "bandido". Lua Nova.São Paulo: CEDEC, n. 79, 2010.p. 15-38.

PADOVANI, Natália Corazza. Sobre casos e casamentos: Afetos e "amores" através de pentienciárias femininas em São Paulo e Barcelona. Tese (Doutorado em Antropologia). Campinas: UNICAMP, 2015.

PIRES, Artur Freita. "A vida do crime é louca": As relações criminais em um complexo de favelas. Dissertação (Mestrado em Sociologia). Fortaleza: UFC, 2018.

RIVERA, Dario Paulo Barrera. Religião e desigualdades sociais no município de São Bernardo do Campo: Estudo comparativo de grupos evangélicos em dois bairros de condições sociais e econômicas opostas. In: RIVERA, Dario Paulo Barrera. (org.). Evangélicos e periferia urbana em São Paulo e Rio de Janeiro: Estudos de sociologia e antropologia urbanas. Curitiba: CRV, 2012. p. 17-64.

RODRIGUES, Fernando de Jesus; SILVA, Ada Rízia Barbosa da; SANTOS, Alana Barros. Notas sobre redes de proteção: facção, família e crime em periferias urbanas de Alagoas. Diversitas Journal, v. 5, n. 3, 2020. p. 2297-2316.

RODRIGUES, Fernando de Jesus. Tradições de agressividade, disciplina e sistema de internação de jovens em Alagoas (1980-2015). Interseções. Rio de Janeiro: UERJ, v. 19, n. 2, 2017. p. 483-513.

RODRIGUES, Fernando de Jesus. “'Necessidade' de 'polícia' e a 'paz' das 'facções': desejos de 'ordem' e efeitos de 'desordem' nas periferias e cadeias de Maceió, AL”. BITTENCOURT, João (org.) Juventudes contemporâneas - desafios e expectativas em transformação. Rio de Janeiro: Editora Telha, 2020a.

RODRIGUES, Fernando de Jesus. "Corro com o PCC", "corro com o CV", "sou do crime": "Facções", sistema socioeducativo e os governos do ilícito em Alagoas. Revista Brasileira de Ciências Sociais. São Paulo: ANPOCS, v. 35, n. 102, 2020b.

SANTOS, Alana Barros. As experiências de rupturas afetivas na família favorecem a aproximação dos adolescentes com práticas ilicitas e criminais?. Trabalho de Conclusão de Curso (Bacharelado em Ciências Sociais). Maceió: UFAL, 2018.

SCHELIGA, Eva Lenita. Trajetórias religiosas, experiências prisionais: A conversão religiosa numa instituição penal. Comunicações do ISER: Religiões e Prisões. Rio de Janeiro: ISER, n. 61, 2005. p. 75-85.

SIMMEL, Georg. The view of life: Four metaphysical essays with journal aphorismos. Chicago: The University of Chicago Press, 2010. 
SIQUEIRA, Ítalo Barbosa Lima; PAIVA, Luiz Fábio. "No Norte, tem Comando": as maneiras de fazer o crime, a guerra e o domínio das prisões do Amazonas. Revista Brasileira de Sociologia.São Paulo: SBS, v. 07, n. 17, 2019. p. 125-154.

TEIXEIRA, César Pinheiro. A construção social do "ex-bandido": Um estudo sobre sujeição criminal e pentecostalismo. Dissertação (Mestrado em Sociologia). Rio de Janeiro: UFRJ, 2009.

1 O caso carioca, não por acaso bastante abordado na bibliografia nacional é bastante significativo. Há pelo menos trinta anos, não apenas o Comando Vermelho se expandiu pelas cadeias do estado, como também a religião pentecostal. Ou seja, ambas tiveram um grande processo de expansão, no mesmo território e no mesmo intervalo de tempo (Johnson; Densley, 2018).

2 Estou demarcando as palavras e expressões nativas com o uso do itálico. Os nomes aqui mencionados são fictícios.

3 Em 2017, segundo o Atlas do Desenvolvimento Humano do Brasil, desenvolvido pelo Instituto de Pesquisa Econômica e Aplicada e o Programa das Nações Unidas para o Desenvolvimento, Alagoas ficou na última posição entre as unidades da federação quando se tratava de desenvolvimento humano. Para ver mais, acessar: https://atlasbrasil.org.br/ranking. Além disso, segundo os últimos Atlas da Violência, Alagoas também tem figurado entre os estados brasileiros com maiores índices de homicídios do país, sobretudo quando se trata de jovens e jovens negros. No mesmo ano de 2017, por exemplo, Alagoas foi o quarto estado do país com maior taxa de homicídios de jovens por cem mil habitantes, atrás apenas do Rio Grande do Norte, do Ceará e de Pernambuco (IPEA, FBSP, 2019; IPEA, 2020).

4 A falar em trajetórias, estou entendendo que os indivíduos são formados por suas vivências e por suas múltiplas aquisições no decorrer da vida, o que interfere na ativação de disposições em situações presentes (LAHIRE, 2002). Além disso, as decisões individuais se inserem em processos sociais não-planejados, cujas dinâmicas determinam suas consequências (ELIAS, 1995).

5 Ainda em uma das atividades da iniciação científica, na pesquisa, Mercados lícitos, Amor e Diversão nas Periferias de Maceió, em que eu fui bolsista CNPq.

6 Expressão usada para quando se falta aulas.

${ }^{7}$ Cobranças são punições perpetradas por membros de facções relativas a erros cometidos no crime. Os ataques são como empreendimentos do crime, visando a expansão de redes de atuação e dos mercados ilícitos em quebradas dominadas por rivais.

8Para saber um pouco mais sobre as relações afetivas e familiares relativas aos garotos e garotas com quem tenho dialogado em unidades de internação, ver: Rodrigues; Silva; Santos, 2020 e Santos, 2018. Os textos referenciados são fruto da pesquisa que temos desenvolvido, Mercados Ilicitos, Amor e Diversão nas Periferias de Maceió. Por meio de entrevistas, temos abordado diferentes dimensões da vida dos adolescentes que são nossos interlocutores, no sentido de compreender, também, um pouco mais sobre as margens alagoanas.

9 Agreste é a região do Nordeste brasileiro que fica entre o que se entende por Zona da Mata, onde normalmente se localizam as capitais, mais ao litoral, e os Sertões, mais ao interior dos estados.

10 Uma espécie de armadilha, em que uma pessoa é levada a um lugar ou conduzida a uma situação enganada, e é então morta. No caso do tio de Efraim, sua esposa é que teria sido a responsável pela cocó.

11 A noção de caminhada diz respeito à trajetória de alguém na vida do crime. Tal trajetória fica sob avaliação moral por parte dos pares, e o indivíduo sujeito a ascensões ou cobranças

12 As Rodas de Conversa consistiam em atividades semanais que realizei em unidades de internação junto a grupos de 5 a 7 adolescentes. Lançando mão de livros infanto-juvenis, músicas, curtas, 
filmes e imagens, minha intenção era ampliar e aprofundar as possibilidades de diálogo com meus interlocutores, tendo uma convivência prolongada em campo, provocando-lhes a partir de perguntas e respostas que nos eram suscitadas por nossas experiências de vida e pelas leituras e escutas que faziamos. Nesses momentos, também lhes colocava questões importantes para a pesquisa que desenvolvia. Para tanto, me inspirei nas propostas de Natália Padovani (2015), Fábio Mallart (2011) e Diogo Lyra (2013) em suas pesquisas de campo.

13 Enunciam vínculos com a facção A ou B.

14 Ao falar em trajetória de institucionalização, no caso de Efraim, me refiro ao fato de ele e sua família terem sido membros regulares e fixos em uma igreja Assembleia de Deus. Ele chegou a cantar no coral de jovens, o que o tornava membro da mocidade da igreja. Seus pais e avós também a frequentavam, bem como suas primas. Ele narrou que o esposo de uma delas era, inclusive, pastor.

Recebido em 10/02/2021

Aceito para publicação em 19/03/2021 


\title{
Lideranças leigas, adequações e conflitos na evangelização do sertão cearense na primeira metade do século $\mathbf{X X}$
}

Lay leaderships, adjustments and conflicts in the evangelization of Ceará backwoods in the first half of the 20th century

\author{
Robério Américo do Carmo Souza1* \\ https://doi.org/10.29327/256659.12.2-5
}

\section{Resumo}

$\mathrm{Na}$ história do cristianismo - em suas diferentes doutrinas e denominações - no Brasil é extensa e rica a contribuição de não sacrdotes, denominados delideranças leigas. Este artigo reflete sobre a atuação desses importantes agentes religiosos na difusão do protestantismo pelo sertão do Ceará nas primeiras décadas do século XX e de como essa atuação contribuiu para configuração de uma experiência religiosa singular por meio de aproximações, adequações e conflitos entre o catolicismo popular e a doutrina presbiteriana.

Palavras-chave: sertão cearense, protestantismo, lideranças leigas.

\section{Abstract}

In the history of Christianity - inits different doctrines and denominations - in Brazil, the contribution of non-priests, called lay leaders, is extensive and rich. This article reflects on the performance of these important religious agents in the spread of Protestantism through Ceará backwoods in the first decades of the twentieth century and how this performance contributed to the configuration of a singular religious experience through approximations, adjustments and conflicts between popular Catholicism and Presbyterian doctrine.

Keywords: Ceará backwoods; Protestantism; lay leaderships.

\section{1) Missionários estrangeiros e brasileiros: limites e possibilidades}

Em notícia publicada na edição de novembro de 1890em seu periódico oficial, a revistaThe Missionary, a organização missionária estadunidense Board of Nashville ofSouthermPresbyteriamChurch, expõe nos seguintes termos o trabalho missionário que realiza no Nortei do Brasil:

\footnotetext{
* possui graduação em História pela Universidade Federal do Ceará (1998), mestrado em História pela Pontificia Universidade Católica de São Paulo (2001) e doutorado em História pela Universidade Federal Fluminense, com estágio sandwich na Université Laval (2008). Tem experiência na área de História e Educação, com ênfase em História Contemporânea e Teoria da História, atuando principalmente nos seguintes temas: História Moderna e Contemporânea, História do Brasil Império e República, Educação Patrimonial e Teoria e Metodologia da Pesquisa e do Ensino História. Dedica-se a pesquisas no campo temático das religiões e religiosidades, memória e política e formação de professores de História.
} 
Nosso trabalho nessa grande República do Sul se faz através de três Missões separadas: Norte do Brasil; Sul do Brasil, e interior do Brasil. A Missão do Norte do Brasil, por sua vez, subdivide-se em três áreas, dadas às grandes distâncias; Maranhão, Ceará e Pernambuco, todas incluídas no Presbitério de Pernambuco.

Maranhão

A Cidade, Ilha de São Luís, tem cerca de 35.000 habitantes. Ocupam-na os senhores Butler e Thompson, ambos casados. O dr. Butler é também médico e ocupa esta estação a 8 anos. O seu campo abrange o Maranhão e o Piauí e são ali os únicos missionários protestantes. Há uma boa Igreja na cidade de São Luís.

Ceará ou Fortaleza, como denominam a cidade de 20.000 habitantes. Ali reside o rev. De LaceyWardlaw, auxiliado por um jovem escocês que a pouco se filiou à Missão, mr. James Dick. Ali também trabalhou o dr. Harrell, até que a enfermidade nele e na esposa o obrigou a voltar. Há uma igreja enérgica e uma escola missionária que, de início teve a sra. Wardlaw como professora, e agora tem miss Sallie Chambers, que para lá embarcou no ano passado com a pranteada miss Cunningham. A morte de miss Cunningham foi uma perda severa. O campo do rev. Wardlaw abrange Ceará e Rio Grande do Norte.

Pernambuco

Cerca de 140.000 habitantes; ali se encontram J. R. Smith e W. C. Porter, com as respectivas famílias. O dr. Smith está, no momento, nos Estados Unidos, mas provavelmente voltará logo.

O dr. Smith chegou a Pernambuco há 18 anos; temos cerca de meia dúzia de igrejas organizadasii, mais de 200 comungantes e 4 pastores nativos. O campo abrange Pernambuco, Paraíba e Alagoas. Há também, um pequeno trabalho da South American Missionary Society, para marinheiros, e a 'Missão Kalley'. E só.

No alvorecer do século XX o cenário descrito pela revista pouco havia mudado. A ação missionária do Board of Nashville havia fundado Igrejas nas principais capitais do então Norte Oriental do país, à exceção de Salvador, cuja evangelização ficou a cargo do Board of New York, que ali se estabeleceu em 1872.

No interior, por sua vez, a presença protestante era quase nula, resumindo-se a duas igrejas no interior de Pernambuco.

Essa configuração era o resultado da estratégia adotada pelos missionários estadunidenses que atuaram no Brasil na segunda metade do século XIX. Buscando espaço em uma sociedade erguida sobre os pilares de uma ética social e uma moral religiosa marcadamente católicas, eles tomaram como público preferencial para sua propaganda os segmentos urbanos descontentes com a Igreja Católica: a pequena burguesia e a classe média em formação (profissionais liberais, funcionários públicos, etc.). Com este fim, veicularam uma mensagem que dava especial ênfase aos aspectos da doutrina protestante que se 
aproximavam dos ideais perseguidos por esses segmentos: progresso, liberalismo, secularização do Estado e racionalismo.iii Conteúdo que era divulgado, essencialmente, por meios escritos, como a imprensa. Nisso, reafirmase a compreensão, como propõe Peter Spink, de que a construção de enunciados discursivos se faz dentro de uma relação intersubjetiva entre produtores e consumidores (SPINK, 1999, p.123)

Esta opção dos missionários estadunidenses fez do discurso missionário difundido nos estados do Norte, com uma população de maioria camponesa e analfabeta, uma mensagem para poucos.

No interior do Ceará a mensagem presbiteriana começou a ganhar espaço apenas no século XX, quando o trabalho missionário passou a ser capitaneado por pastores brasileiros, inicialmente com o rev. Antônio Almeida (1907-1911), seguido pelo rev. Raimundo Bezerra Lima (1911-1915) e, finalmente, rev. Natanael Cortez (1915-1943), considerado o mais importante missionário protestante da história do Nordeste brasileiro, em cujo pastorado foram fundadas as primeiras igrejas protestantes (presbiterianas) no sertão alencarino.

Estes pastores promoveram uma importante e decisiva mudança no conteúdo e na forma da mensagem de evangelização. O Deus pregado pelos pastores nacionais - como eram referidos os primeiros brasileiros ordenados ministros do evangelho na Igreja Presbiteriana - é definido por seus sentimentos de amor e misericórdia, diferente do Deus de justiça pregado pelos missionários estadunidenses. A mensagem passou a assentar-se sobre os princípios do perdão e a misericórdia divina e não mais se põe as leis da igreja como complemento da fé para alcançar a salvação. Não que as leis e a disciplina da igreja tenham sido abolidas ou rejeitadas, mas sim que o zelo por elas deixou de ser o centro da doutrinação, em lugar passou a figurar a preocupação com o sentimento do fiel, em outras palavras, a ênfase da religiosidade deixa de estar no estímulo a uma relação racional homem-Deus, na qual o cumprimento de normas racionalmente elaboradas se torna imprescindivel, e passa a ser o cultivo de uma relação mais ligada ao coração, na qual o mais importante é o cultivo de sentimentos de afeição do crente por Deus e por sua igreja.

Dessa forma, rompe-se com o formalismo da doutrinação missionária, aproximando mais o presbiterianismo do modo de pensar do brasileiro, caracterizado por uma aversão à formalidade ritualística, preferindo, mesmo na sua relação com o sagrado, um convivio de fundo emotivo. 
A despeito desta importante inflexão na mensagem evangelizadora, os pastores nacionais eram, ainda, muito influenciados pelas orientações e pelo exemplo dos missionários estadunidenses na condução da administração da igreja e da disciplina do rebanho. Essa continuidade é compreensivel, afinal, são as missões estadunidenses a raiz do protestantismo que professam. Foi sob a tutela de seus missionários e depois no Seminário Presbiteriano do Norte (1899), fundado e dirigido por teólogos vindos do Sul dos Estados Unidos, que esses primeiros pastores estudaram e foram ordenados.

Outro aspecto importante, observado ao longo do estudo, diz respeito a atuação de lideranças leigas (sem formação teológica) na direção das congregações presbiterianas instaladas no interior do Ceará. No período que vai de 1891 a 1930, a Igreja Presbiteriana de Fortaleza (IPF) e suas congregações foram, em regra, assistidas por um único pastor. Essa situação fazia com que as visitas pastorais às congregações sertanejas fossem intercaladas por longas ausências, durante as quais os fiéis eram dirigidos, em suas obrigações religiosas, por líderes leigos. Compreender a atuação dessas lideranças leigas, com especial foco na relação que ela estabeleceu com os parâmetros institucionais do presbiterianismo, constitui-se, então, em elemento chave para a compreensão da história do cristianismo de matriz protestante no Ceará.

\section{2) Evangelização leiga e controle institucional}

$\mathrm{Na}$ história do cristianismo no Brasil é extensa e rica a contribuição dada por lideranças leigas. Desde a colonização portuguesa que, a grande extensão territorial, somada à escassez de padres católicos - agentes quase exclusivos da catequese cristã na América portuguesa, naquele periodo - contribuiu para o surgimento de irmandades católicas leigas, instituições que atuavam no amparo e orientação espiritual da população, em especial dos pobres e escravos. (HOORNAERT, 1974, pp. 26-40)

Situação semelhante se deu entre os imigrantes de confissão protestante que entraram no Brasil num período anterior à chegada dos missionários estadunidenses. Obreiros leigos atuaram como guias espirituais entre colonos alemães que se estabeleceram no interior de São Paulo e nas províncias da região Sul (MENDONÇA, 1995, p. 26).

Quando chegaram ao Brasil, na segunda metade do século XIX, os missionários vindos dos Estados Unidos, a despeito da intensa discriminação 
que faziam em favor do especialista, do pastor, também fizeram uso de lideranças leigas na condição de auxiliares seus na obra de evangelização do país. Antes de enviar à Fortaleza o rev. De’LaceyWardlaw, a Junta Missionária Presbiteriana do Board of Nashville enviou para lá o pregador leigo e colportor, José Pereira Guerra, para que preparasse a chegada do missionário. Dos 13 primeiros conversos batizados pelo rev. Wardlaw, em 1883, e que formaram a congregação que em 1891 deu origem à IPF, quatro foram conquistados pelo trabalho feito por Pereira Guerra antes da chegada do missionário.

Com o objetivo de uniformizar e disciplinar o trabalho dessas lideranças leigas, os missionários buscaram capacitá-los por meio de manuais de orientação de conduta. Um desses primeiros manuais foi $O$ Culto Dominical, editado na cidade do Rio de Janeiro, em 1878, pelo missionário J. J. Ranson. Em seu prefácio, transcrito por Carl J. Hahn, lê-se:

Em muitos lugares tem-se espalhado numerosos exemplares das Escrituras Sagradas, e há muitos que desejam um culto simples, racional, puro e agradável a Deus. Há lugares onde não visitou pregador algum e onde, contudo, há quem deseje um Culto Dominical em língua inteligivel. A todos esses fazemos a seguinte PROPOSTA:

Onde houver qualquer cidade, vila, aldeia ou vizinhança, dez pessoas que se comprometam a congregarem em um lugar conveniente, de manhã, ou de manhã e de tarde, nos domingos, obtenham este livro, e uma delas faça as vezes de ministro, dizendo no competente lugar as partes que lhe pertencem e as outras dando as respostas, e juntamente com a primeira fazendo as 'confissões gerais', etc.

Creio que estas fórmulas são claras, de modo que ninguém deixe de compreender tudo o que nelas há, mas se suscitar-se qualquer dúvida na inteligência de alguém sobre o que vai escrito, queira escrever-me, e farei o possivel para dar as explicações precisas.

Em todos os lugares onde fizerem uso deste livro, peço que me escrevam sobre o fato e farei esforços para ajudar-lhes a compreender não só a letra, mas também o espírito do culto divino (HAHN, 1989, pp.423-244).

A despeito do exagero na avaliação que faz da eficácia da distribuição de Bíblias na conquista de adeptos à fé protestante, o prefácio do rev. Ranson em muito contribui para compreensão do que queriam os missionários estadunidenses das lideranças leigas.

Já em seu primeiro parágrafo, o texto evidencia com clareza o perfil de quem deve manuseá-lo. Esse leitor deve ser alguém que deseje "um culto simples, racional, puro e agradável a Deus". O que se verifica nessa definição é 
aquilo que Roger Chartier chamou de construção do leitor ideal, sobre o qual aqueles que escrevem "...tem sempre uma clara representação: são as competências que nele supõe, que guiam seu trabalho de escrita e de edição; são os pensamentos e as condutas que desejam nele que fundam seus esforços e efeitos de persuasão" (CHARTIER, 1996, p. 20).

Em outras palavras, se, por um lado, a simplicidade e o racionalismo como elementos basilares na construção dos ritos de devoção ao sagrado são uma característica da religiosidade protestante em sua faceta puritana, por outro, atendem à construção de uma representação da liderança leiga que se quer trabalhando na obra de evangelização do Brasil.

Outro aspecto importante, diz respeito ao apreço dos missionários estadunidenses pela formalidade na condução dos ritos religiosos e seus desdobramentos, ao menos no plano ideal, do que deveria ser a condução de um culto sem a presença de um pastor.

Em seu segundo parágrafo, o texto determina que num culto com a participação apenas de leigos um deles deve fazer as vezes de ministro. Vezes que, mais à frente, é definida como a enunciação de trechos do manual, nada mais, à qual os demais deverão responder lendo outros trechos do mesmo manual. Esse exercício, a moda de um jogral, cerceia, ou pelo menos tenciona fazê-lo, qualquer expressão espontânea, subjetiva dos leigos, num claro esforço por disciplinar a relação que mantinham com o sagrado, pondo-a em acordo com o que preconiza a doutrina protestante.

Esse mesmo objetivo regulador da atuação leiga é pretendido por um outro livro chamado Mannual de Culto para uso da Egreja Presbyteriana do Brazil, editado pela primeira vez, na cidade de São Paulo, em 1892. Nele encontramos as seguintes orientações:

O povo que viver em qualquer localidade e que deseje prestar o culto racional de accordo com as Sagradas Escripturas pode reunir-se para este propósito em algum lugar adecquado e escolher um leitor para presidir o culto.

As formas de culto apresentadas são especialmente preparadas para orientar aquelles que não estão habituados a dirigir um culto público. A ordem é a geralmente observada nas egrejaspresbyterianas do Brazil....

A hora de comecçar o culto divino, as pessoas que irão participar delle deverão estar dentro da egreja, sentados de manneiradeccente, graves e reverentes.

Durante o culto todos deverão prestar séria e reverente atencção, abstendo-se de ler qualquer cousa excepto o que for o pastor ou o leitor estiver lendo ou citando. 
Deverão também abster-se de cochichar uns com os outros, ou de saudar as pessoas presentes ou que estão entrando, de olhar ao redor, de dormir, ou de qualquer outra irreverência. As mães e pajens deverão fazer todo o possível para conservar as crianças quietas, e quando não podem fazel-o deverão conduzil-as para um lugar conveniente onde o choro dellas não perturbe as demais pessoas.

O povo devera ficar de pé durante as oracções. A pessoa que dirige o culto devera dar innício ao mesmo dizendo "invoquemos o Senhor Nosso Deos.

Terminada a oracção a congregação deve cantar um hyno. O dirigente do culto escolhera o hyno e, após lel-o, fará o seguinte convite para câncto: Canctemos em louvor a Deos o hyno 132.iv

Este manual, segundo informa Hahn, foi muito importante na obra missionária presbiteriana no final do século XIX e início do século XX (HAHN, 1989, p. 195). Os trechos acima citados foram retirados de um exemplar que pertenceu ao sr. João Porfirio Varela, funcionário da Rede de Viação Cearense (RVC), e o principal evangelizador leigovdo presbiterianismo no Ceará, no início do século XX, sendo o fundador de três congregações: Aracoiaba, Quixadá e Iguatu. Por ter servido de orientação a um tão importante agente leigo da evangelização protestante no sertão cearense, esta obra tornou-se uma fonte de grande relevância para este estudo.

Infelizmente, ainda que guardado como um tesouro de família por seu neto, o sr. Alberto Varela, diácono da Igreja Presbiteriana de Fortaleza, o livro encontra-se num estado de conservação precário, faltando algumas páginas, entre elas a folha de rosto, o que não permitiu a coleta dos dados catalográficos, como, por exemplo a data em que foi editado. Porém pelas informações que obtive junto a família Varela e a outros pesquisadores, tudo indica que seja um exemplar da primeira edição.

O autor do Mannual do Culto foi o pastor presbiteriano Modesto Parestello Barros de Carvalhosa. Natural da Ilha da Madeira, Carvalhosa teve ali seus primeiros contatos com a religião protestante, por intermédio do médico e missionário britânico Robert ReidKalley, que atuava na ilha prestando assistência espiritual aos seus compatriotas, função que, em 1855, passou a desempenhar na cidade do Rio de Janeiro.

Carvalhosa veio para o Brasil no final da década de 1850. Em 1867 integrou, juntamente com os brasileiros Miguel Gonçalves Torres e Antônio Bandeira Trajano a primeira e única turma do seminário presbiteriano criado por A. G. Simonton no Rio de Janeiro. 
Após sua ordenação, em 1870, o rev. Carvalhosa trabalhou como pastor em várias igrejas presbiterianas nas províncias do Rio de Janeiro, São Paulo e Paraná. Sua atuação principal, no entanto, foi como um intelectual da IPB. É dele a primeira tradução do Novo Testamento do original para o português, bem como a tradução de uma série de importantes obras da teologia protestante anglo-saxônica como o Compendiumof Christian Doctrine, de F. L. Patton e Commentaryon st. Mark, de J. C. Ryle.

A formação pelas mãos do primeiro missionário presbiteriano no Brasil e sua atuação como tradutor de obras de teologia, fez do rev. Carvalhosa um típico pastor da velha escola do sul dos Estados Unidos, conservador e formalista até a medula. Esta condição marca fortemente o seu Mannual de Culto, em especial na preocupação deste com uma rígida política de "disciplinamento do corpo" (VIGARELLO, 1996, pp. 07-20) daqueles que participam da celebração do culto.

Ao estabelecer exigências de como as pessoas devem portar-se durante o culto, quando e como sentar, quando ficar de pé, não falar, não olhar em volta, etc., o manual busca o estabelecimento de uma programação racionalizada de gestos e posturas dos celebrantes. Esta busca evidencia uma compreensão de que o desvio do caminho da boa conduta cristã vincula-se a uma fraqueza física, que o autor denomina genericamente de "irreverência". Nesse sentido, sua orientação se mostra em perfeita sintonia com elementos do puritanismo de matriz calvinista, berço da doutrina presbiteriana, no qual a condenação de gestos e excessos a um só tempo materializa e simboliza o mal que a humanidade carrega desde o pecado original: a desobediência a Deus (WEBER, 1994, pp. 67-90).

Em outros termos, o que as palavras transcritas do Mannual de Culto, especialmente aquelas do terceiro, do quarto e do quinto parágrafos, como de resto todo ele, tencionam ensinar aos leigos é a importância da obediência e da reverência à doutrina da igreja, como forma de fazer-se agradável a Deus. Deus que, na obra do rev. Carvalhosa está bem mais próximo do Deus de Justiça, pregado pelos missionários estadunidenses do que do Deus de Amor, pregado pelos pastores nacionais.

\section{3) Lideres leigos entre a negociação e o conflito}

Até aqui as reflexões foram dedicadas à tentativa de compreender a função e o conteúdo dos manuais elaborados para orientação de líderes protestantes leigos. Avançar na proposta ensejada pelo título deste tópico implica orientá-las 
na direção da busca pela resposta a uma inquietante e necessária pergunta: qual o efeito desses manuais sobre a atuação dos evangelizadores leigos no sertão do Ceará?

Em carta escrita a sua esposa, a sra $^{\mathrm{a}}$. Donana Varela, que visitava uma irmã na cidade de Fortaleza, o sr. João Porfirio Varela assim relata um culto na congregação que dirigia na cidade de Iguatu:

O culto de domingo se deu numa ampla sala da casa dos
irmãos Aloízio Bandeira e D. Maria Bandeira, na rua 15 de
Novembro. Tem aquella casa um espaço superior aquelle de
nossa residênccia, pelo que será doravante a sede de nossa
Congregação.
Como de habito dei abertura ao culto com uma oracção ao Pai
Celestial roganod-lhebencçãos e protecção aos crentes ali
reunidos. Tudo se deu denctro da normalidade e tranqüilidade
de sempre. A excepção foi a insistência que teem os crentes
daqui de dirigir saudacções e cumprimentos aos chegam em
atraso, o que ocorreu com maior freqüência pôr ter sido o culto
em logar novo. Foram muitas as interrupções, o que dexou-me
deveras agastado.
(...) Por uma veiz mais busquei com a graça de Nosso Senhor
Jesus convencer D. Juventina de que nosmommentos de
oracçãoelladveria pôr-se de pé como as demais pessoas. Ella
contudo teima em dizer que é de joelhos que se deve ficar.
Mostrei a ella uma vez mais o que diz o nosso Mannual de
Culto, mas de nada adiantou.

Datada de 8 de dezembro de 1915, o relato do sr. Varela traz algumas apreciações sobre as quais importa ponderar. A primeira diz respeito a imagem que ele constrói de si mesmo, como um evangelizador que zela pelo fiel cumprimento da liturgia definida pelo manual que o orienta. Zelo, que de tal forma lhe é caro, que ver descumprida a liturgia lhe deixa "agastado".

O comportamento do sr. Varela denota uma perfeita sintonia com os objetivos que tinham Ranson e Carvalhosa ao redigirem seus manuais: uniformizar a liturgia do culto dominical e disciplinar a atuação dos evangelizadores leigos. O sr. Varela seria, então, a encarnação do leitor ideal do Mannual de Culto, alguém cujos pensamentos e condutas corresponderiam à perfeição às representações formuladas por seu escritor.

Tudo parecia perfeito, um encadeamento harmonioso entre letra, teoria e prática, na atuação do sr. Varela, que a mim deixava "agastado", ainda mais quando lembrava da ponderação de Chartier, de que o leitor ideal, não é mais que isso, um ideal. 
Foi no exercício corriqueiro, e tão necessário ao fazer historiográfico, de entrecruzar fontes, que encontrei subsídio para o que, até então, era apenas um incômodo intuitivo de pesquisador. Em Ata de Reunião do Conselho da Egreja Presbiteriana de Fortaleza, de 26 de abril de 1916, o rev. Natanael Cortez faz o seguinte registro em seu relato de viagem pastoral:

\begin{abstract}
Na congregação de Iguatu o irmão Porfirio Varela, que lha dirige na retidão dos caminhos do Nosso Senhor Jesus Christo, instaurou uma cousa nova. No logar de iniciar o culto com uma oracção, como orienta a tradicção litúrgica que seguimos, elle o faz com o cântico de um hynno. Disse-mo o irmão que lho fazia por apêlo da congregação, que assim se fazia mais animmada na devocção ao Senhor Nosso Deos. Facto que eu mesmo pude atestar, pêlo que assenti que assim continuasse.
\end{abstract}

Se em próprio relato o sr. Varela figura como um cumpridor rigorosa da liturgia descrita no Mannual de Culto, neste do rev. Cortez ele aparece como alguém mais flexível, capaz de alterar a ordem do rito em beneficio de um maior ânimo da congregação que lidera.

Qual o verdadeiro sr. Varela, o do primeiro ou o do segundo relato? Ainda que tentador, esse é na verdade um falso problema, ao menos no que diz respeito a uma investigação historiográfica.

A contradição entre os dois relatos pode e deve ser compreendida como um aspecto intrínseco à experiência social do sr. Varela como evangelizador leigo. Quando rompe com seu zelo pela ortodoxia litúrgica iniciando o culto de uma maneira nova ele não evidência mais que o fazer-se da experiência social, que, entre outros aspectos, caracteriza-se pelas contradições e pelos conflitos. Contradições e conflitos devem ser, portando, interpretados pelo historiador não como erro ou desvio, mas, outrossim, como a riqueza própria da vivência humana em sociedade.

Nesse sentido, é legítimo inferir que na experiência de evangelização protestante do sertão cearense pelas mãos dos leigos, os manuais de liturgia desempenham uma função de moldar e disciplinar comportamentos, mas que não pode ser compreendida como um absoluto, mas sim como um paradigma passivel ser questionado e transgredido.

Entrementes, antes de ponderar sobre a segunda apreciação presente na carta à $\mathrm{sr}^{\mathrm{a}}$. Donana Varela, importa registrar que, no processo de 
adequação/reinvenção por que passou o culto protestante em terras brasileiras o apego dos crentes aos cânticos parece ter um papel relevante.

Numa outra ata do Conselho da IPF, de 12 de junho de 1908, o então evangelizador leigo da congregação de Baturité, o sr. Bezerra Lima, registra que, por demanda dos crentes de lá, incorporou ao culto dois novos momentos de cântico de hinos, além dos já previsto na liturgia do Mannual de Culto. Em sua pesquisa sobre o protestantismo na cidade Caruaru, interior de Pernambuco, a historiadora Rosimeire da Silva afirma que a música foi um importante fator de conquista de fiéis pelos pregadores protestantes (SILVA, 2002, p.46). Em seu livro A igreja presbiteriana da autonomia aocisma, Boanerges Ribeiro escreveu um capítulo denominado "A igreja canta", em que fala sobre como os hinos eram apreciados pelos primeiros brasileiros a se converterem ao protestantismo no século XIX (RIBEIRO, 1987, pp. 133-140).

A segunda apreciação da carta do sr. Varela é sobre o comportamento dos crentes da congregação de Iguatu durante a celebração do culto. Por duas vezes o evangelizador faz críticas a atitudes que se opõem ao que preconiza a liturgia do Mannual de Culto.

A primeira dessas críticas é dirigida à falta de observação, pelos fiéis, da orientação para não cumprimentar os que chegam atrasados à cerimônia, ato que é classificado como "irreverente" e que, portanto, rompe com a reverência que a ordem litúrgica exige. Esse comportamento deveria ser algo recorrente entre os crentes brasileiros e por isso é condenado explicitamente pelo Mannual de Culto. Nesse sentido, sua ocorrência e sua condenação pelo condutor do culto eram esperadas. O que surpreende é motivo da segunda crítica do sr. Varela, feita a insistência da sr ${ }^{\mathrm{a}}$. Juventina em ajoelhar-se nos momentos de oração.

O gesto da $\mathrm{sr}^{\mathrm{a}}$. Juventina nada tem de irreverente, ao contrário, demonstra uma reverência maior do que a exigida. Por que então ela incomoda o sr. Varela?

A resposta está na ruptura da uniformidade do rito que o gesto provoca. Ainda que reverente e grave, como exige o Mannual de Culto seja a atitude dos fiéis durante o culto, o gesto de ficar de joelhos rompe com a uniformidade litúrgica, que é um dos objetivos maiores desse tipo de manual, por isso deve ser criticado e corrigido.

Para além de apontar tipos de transgressão litúrgicas dos crentes do sertão, a carta do sr. Varela evidencia sua diversidade. Se por um lado o erro se 
faz pela irreverência, por outro se dá pelo excesso de reverência, numa clara demonstração que a atitude dos sertanejos que se converteram ao protestantismo não foi apenas de dificuldade em aceitar as normas, mas também de internalização radical de sua observância, numa demonstração explícita do caráter plural que caracteriza toda e qualquer experiência histórica. Pluralidade que também se dava no perfil dos evangelizadores leigos no Ceará.

Por outro lado, o comportamento da $\mathrm{sr}^{\mathrm{a}}$. Juventina pode e deve ser compreendido, também, como a permanência de atitudes características do catolicismo popular sertanejo, que, como já discutido no capítulo I, tem na penitência uma de suas mais fortes características.

O sr. Varela era um homem da cidade, com boa educação formal e membro antigo da IPF, o que lhe havia proporcionado uma formação religiosa sólida. Mestre de obras da RVC, fez das constantes mudanças de cidade que o oficio lhe impunha uma forma de disseminar entre os sertanejos a fé protestante. Outros evangelizadores, porém, possuiam uma origem e uma formação bem distintas, como é o caso do sr. Francisco Sousa, líder da congregação Ebenézer.

A história do sr. Francisco Sousa e da congregação Ebenézer começa com uma viagem pastoral do rev. Natanael Cortez, em 1917, à cidade de Cedro, onde a IPF tinha uma congregação. Saindo de Iguatu, a viagem a cavalo até o cedro durava menos de um dia. Contudo, aquela viagem específica (por uma série de percalços, que depois o pastor atribuiu à providência divina) tornou-se mais longa e ele se viu obrigado a pernoitar em uma vila de nome Vencedor, a alguns quilômetros de seu destino.

Acolhido pelo sr. Francisco Sousa, Cortez, segundo relato em seu livro de memórias, de pronto identificou-se como pastor evangélico e solicitou permissão para realizar uma reunião com alguns moradores da vila para falar-lhes do "maravilhoso plano de Deus para suas vidas", ao que, mesmo se declarando "um fiel católico", aquiesceu o dono casa, mas com a condição de que tal se desse na varanda ou no terreiro, fora da residência. "Fora da residência", essa condição imposta pelo sr. Francisco muito nos revela sobre ele próprio, como também sobre a cultura a qual se vincula, exigindo, assim, uma breve ponderação sobre a relação entre a casa, a vida e a fé no sertão.

O dicionário Aurélio define a varanda como uma "espécie de alpendre à frente e/ou em volta das casas, especialmente as de campo". No Brasil, em regiões com insolação mais intensa, a varanda é muito comum, como forma de 
atenuar a temperatura interna das casas através de um colchão de sombras que resguarda as paredes.A definição fisica da varanda não contempla o universo simbólico que cercava a criação e a utilização desse espaço do domicílio. Para além de seu papel na atenuação dos rigores do clima, a varanda, propõem Veríssimo e Bittar, pode ser compreendida como o marco da tênue fronteira entre o mundo exterior e a incipiente intimidade da família (VERÍSSIMO, 1999, p.131).

Entre as linhas descritivas da arquitetura colonial paulistana (LEMOS, 1999), atravessando as empreitadas bandeirantes até a arquitetura da pecuária (VIEIRA JUNIOR, 2002), emerge uma complementação à definição do dicionário: a varanda era uma extensão do terreiro, uma fronteira entre o mundo público e o privado, sendo utilizada para dar abrigo e refeição aos viajantes. Assim, ao delimitar a varanda ou o terreiro como os espaços em que permitiria ao rev. Cortez realizar sua reunião, o sr. Francisco agiu em defesa da preservação da privacidade de seu lar.

Por outro lado, como nos assevera Mircea Eliade, o homem religioso vive uma experiência não homogênea do espaço, o qual é bipartido em profano e sagrado, partes entre as quais ele estabelece uma fronteira, um lugar paradoxal onde os dois mundos se comunicam, como por exemplo, o templo. Ainda segundo Eliade:

(...)uma função ritual análoga é transferida para o limiar das habitações humanas, e é por essa razão que este último goza de tanta importância. Numerosos ritos acompanham a passagem do limiar doméstico: reverências ou prosternações, toques devotados com a mão etc. O limiar tem seus 'guardiões': deuses e espíritos que proíbem entrada tanto aos adversários humanos, como às potências demoníacas e pestilenciais (ELIADE, 1999, p.29).

Nesse sentido, permitir que a pregação do pastor evangélico ocorresse no interior da casa poderia ser algo ofensivo à devoção católica do sr. Francisco a qual, entre outros, se definia pela prática da devoção religiosa praticada nos altares comumente instalados nas salas das casas sertanejas àquele tempo.

Além da família Sousa compareceram à reunião mais nove pessoas, entre parentes e vizinhos do anfitrião, totalizando uma platéia de quatorze ouvintes. Ao fim da pregação o sr. Francisco, sua esposa D. Antônia e mais quatro outros 
"manifestaram interesse em abraçar a fé em Cristo" pelo que resolveu o pastor ali fundar uma congregação a qual chamou Ebenézer (CORTEZ, 1965, p. 21).

Como não havia em toda a vila fiel evangélico antigo, experiente, Cortez resolveu adiar o prosseguimento de sua viagem por mais dois dias para prestar assistência aos conversos e preparar algum deles para assumir a liderança da congregação. Para função de líder foi escolhido o sr. Francisco Sousa, pois entre as novas ovelhas do pastor Cortez era o único que sabia ler e escrever, assim, recebeu uma bíblia, única em toda a vila, e um exemplar do Breve Catecismo Presbiteriano, com os quais deveria guiar os conversos no "correto caminho de Deus"(CORTEZ, 1965, p. 21).

Deixando a vila no dia cinco de agosto, o rev. Natanael Cortez passou a corresponder-se mensalmente com o sr. Francisco Sousa, com o duplo objetivo de informar-se sobre o andamento da congregação e de continuar sua instrução na doutrina presbiteriana. Tudo corria bem, até a chegada da carta de maio de 1918. Nela o sr. Francisco relatava a celebração da páscoa ocorrida no mês anterior. Este relato foi assim registrado na Ata de Reunião do Conselho da IPF de 16 de maio de 1918:

Conforme Vossa orientação realizamos um culto na parte da manhã em que foi lido o cap. II do Livro Actos dos Apóstolos e a Mensagem que o senhor enviou na carta. Na parte da noite o povo se reuniu no terreiro da Congregação, onde se fez um leilão das offertas que eles deram e foi erguida a bandeira em homenagem ao Divino Espírito Sancto, bordada por minha espôsa e pela D. Geralda. Tudo ia bem até que chegaram uns bêbados e começaram a brincadeira do pau de sêbo, que aqui eles gostam muito e foi muita anarchia até de manhã. Na segunda-feira muitos só foram trabalhar na parte da tarde, outros nem isso.

Transcrita em ata de reunião do Conselho da Igreja Presbiteriana de Fortaleza, convocada extraordinariamente para debater aquele assunto, a narrativa do sr. Francisco Sousa foi motivo de indignação e receio entre os conselheiros, sentimentos resumidos na falado presbitero José Baltazar Lopes Barreira, também registrada na Ata de Reunião do Conselho da IPF de 16 de maio de 1918:

(...) tal episódio representa um grave desvio dos princípios da boa conductachristã e deixa clara a necessidade de uma acção doutrinária rígida para aquelles irmãos em Christo não mais incorrerem nos erros da idolatria e da prevaricação, garantido 
dessa forma a preservação do exemplo da Egreja de Christo em terras cearenses.

Ao fim da reunião o Conselho deliberou pelo envio do rev. Natanael Cortez e do presbítero José Zaqueu Maia para uma visita disciplinar de três dias à Congregação Ebenézer, com o objetivo de corrigir os "desvios" de comportamentos dos fiéis.

O que a cúpula da IPF tratou como "desvio" e "erro" pode e deve, como no caso gesto de dona Juventina, ser compreendido como permanência de elementos da experiência daqueles sujeitos com a religiosidade católica popular.

Como religião hegemônica, o catolicismo marcou profundamente a cultura cearense. O calendário litúrgico católico desde os tempos coloniais regulava o cotidiano, em especial nas comunidades rurais. Marcar os dias sagrados com momentos de festividades e louvores religiosos era prática corrente e solidamente internalizada na cultura local, constituindo-se como exercício de sociabilidade e lazer (HONAERT apud CAMPINA, 1992, p. 6)

As comemorações religiosas no Ceará, àquele período, guardavam sempre um caráter festivo. Sob o signo do catolicismo, "todas as festas, inclusive as civis tinham caráter religioso e os rituais estabelecidos pela tradição. Entre a Epfânia e a Quaresma, festas celebravam Nosso Senhor do Bom Fim, em janeiro, e a Purificação de Nossa Senhora em Fevereiro. Da Quaresma à Páscoa era tempo de penitência, jejum e oração(...)Pentecostes, Corpus Christi, São José davam lugar a procissões sempre acompanhadas de festejos populares" (DELLA CAVA, 1977, p. 18).

Essas festividades sempre tiveram um caráter coletivo, onde o religioso e o profano se imbricavam numa simbiose garantida pela tradição do "dia santo", isto é, um dia em que se venerava um santo determinado e em que as atividades seculares, como o trabalho, eram suspensas. Os dias santos e as festividades a eles vinculadas figuravam, então, como ponto alto da religiosidade católica.

Assim, é legitimo que, o que a cúpula presbiteriana tratou como desvio por perceber as festas e símbolos religiosos, como a Bandeira do Divino, como paganismo e idolatria - seja compreendido pelo historiador como um fenômeno de permanência de aspectos da experiência religiosa original dos fiéis da Congregação Ebenézer, experiência que também desagradava à cúpula da Igreja Católica. 
Na leitura dos Livros de Tombo da Paróquia do Cedro, a qual pertencia a vila de Vencedor, foram encontradas queixas dos vigários sobre o comportamento dos paroquianos da referida vila.

... os missionários qualificaram de indisciplinado o povo do Vencedor. É que o Vencedor recebeu pouca instrucção religiosa. $\mathrm{Na}$ festa da padroeira dividiam-se em dous partidos: Santa Terezinha e Divino Espírito Santo... os partidos tiram da festa o sentido religioso e espiritual e lhe emprestam uma feição profana.

... realmente o povo da Vila Vencedor bate o Record na superstição religiosa. Adoram uma velha imagem de Nossa Senhora da Conceição no lugar de uma nova. E é inútil o Vigário esclarecer o culto das imagens: querem ser mais católicos que o Papa. É este um caso a ser resolvido o espinho da garganta dos vigários. Aliás a Vila Vencedor tem outros problemas mais exigindo solução.

Estas sucessivas reclamações registradas pelo pe. Aluísio Ferreira Lima, vigário da Paróquia do Cedro, nos livros de tombo da Matriz de Nossa Senhora do Perpétuo Socorro de 1916 e 1919, evidenciam um conflito entre a orientação católica institucional e a prática cotidiana da religiosidade pelos fiéis, num fenômeno bem próximo daquele em torno da celebração da páscoa entre os membros da Congregação Ebenézer.

A celebração da páscoa na Congregação Ebenézer é ainda importante para se relativizar a abertura que havia, entre os pastores nacionais, a incorporação de práticas tradicionalmente católicas à religiosidade presbiteriana. Ao mesmo tempo que tomaram como aceitável o velório e a missa de corpo presente, outras práticas foram rejeitadas, num jogo característico do processo de apropriação de uma nova prática cultural, que, invariavelmente, é marcado por movimentos de assimilação, rejeição e reinvenção.

Os episódios de quebra da liturgia protagonizados por dona Juventina e pelos membros da Congregação Ebenézer insinuam aquilo que ao longo da pesquisa foi se configurando no foco central desta tese: compreender como se deu o diálogo entre a religião protestante com a cultura dos sujeitos sociais do sertão, a qual é denominada pelos especialistas como "cultura popular".

\section{4) Reinventando conceitos e práticas: evangelização leiga como expressão da cultura popular}


Qualquer historiador que tencione conduzir uma pesquisa que envolva uma discussão sobre cultura popular irá se deparar com um campo espinhoso em que se digladiam várias e complexas tendências teórico-metodológicas. Com efeito, os teóricos que se lançam ao desafio de abordar esta questão têm demonstrado que não é fácil constituir definições fechadas sobre o conceito de cultura popular.

O historiador italiano Carlo Ginzburg, para estudar as ideias, sentimentos e crenças de um moleiro friulano condenado pelo Tribunal do Santo Ofício, toma por referência a ideia de "circularidade cultural", cunhada por Mikhail Bakthin, que pode ser definida nos seguintes termos: "entre a cultura das classes dominantes e a das classes subalternas, existiu, na Europa pré-industrial, um relacionamento circular feito de influências recíprocas, que se movia de baixo para cima, bem como de cima para baixo" (GINZBURG, 1987, p. 13).

A aplicação deste conceito não considera as eventuais distinções entre cultura erudita e cultura popular, mas insere no cerne do debate uma questão básica: as diferenciações e virtuais fronteiras não se configuram de maneira cristalizada, compartimentada e estanque, como outrora se acreditava. Tal concepção de cultura em sua trajetória circular propicia, também, desvencilharse de postulados pseudo-científicos que, por vezes, continuam largamente creditados, como a assertiva que propõe a "deformação" das ideias, normas e crenças "superiores" durante transmissão às classes subalternas.

Ginzburg ainda dirige uma invectiva demolidora à chamada história quantitativa das ideias, ou história serial, muito em voga nos anos 1960 e 1970, criticando o pressuposto da inequivocidade dos dados elaborados e documentos coletados, como se estes pudessem, per se, exprimir uma fala do passado.

Ao salientar a crença simplória de que uma história calcada em bases estatísticas pode bastar-se, prescindindo das estratégias da interpretação e explicação do processo histórico, Ginzburg argumenta sobre o significado de estudar indivíduos incomuns - tais como o moleiro Menochio - a fim de perceber as limitações de categorias como "camponês típico" e perceber a "cultura popular" em suas possibilidades latentes de articulação, quase sempre mais complexa do que costumamos supor, com a "cultura erudita".

Igualmente virulenta e procedente é outra verberação tecida por Carlo Ginzburg, desta vez contra a história das mentalidades, uma vez que ela se detém sobre elementos residuais, inconscientes e irracionais, defasagens e 
inércias supostamente comuns a toda uma coletividade e ditadas por um tempo de longa duração. Desta maneira, tende a investigar grupos circunscritos e com especificidades marcadas, ampliando sua análise de modo a abarcar uma sociedade inteira, sem menção relevante às diferenças presentes nos diversos segmentos sociais (o exemplo citado é o Rabelais, de Lucien Febvre). Asseverando, nesses termos, que uma "análise de classes é sempre melhor que uma interclassista” (GINZBURG, 1987, p. 26), Ginzburg prefere então inscrever sua empreitada no âmbito da "cultura popular" - expressão que, embora visivelmente incômoda, revela seu propósito com maior clareza e rigor que as mentalités.

Ainda que pouco ortodoxo em suas colocações e argumentos, Ginzburg empreende uma defesa visceral da compreensão histórica numa perspectiva cultural, que revele e problematize a inserção, o alcance e os limites da ação individual dentro da tessitura social.

Aos atuais defensores do linguisticturnousemiologicchallenge, que pretendem enveredar pelo entendimento da linguagem como sistema autocontido de signos, criador de sua própria dinâmica e fundador da realidade, Ginzburg cetamente exprimiria sua provocação intelectual nos seguintes termos: "da cultura do próprio tempo e da própria classe não se sai a não ser para entrar no delírio e na ausência de comunicação. Assim como a língua, a cultura oferece ao indivíduo um horizonte de possibilidades latentes - uma jaula flexível e invisível dentro da qual se exercita a liberdade condicionada de cada um" (GINZBURG, 1987, p. 27).

Em seu artigo “ 'Cultura popular': revisitando um conceito historiográfico”, Roger Chartier, tencionando ao menos apontar um caminho a ser seguido (o que já é bastante ousado), traz alguns pontos relevantes para o debate, quando desloca a percepção da diferenciação entre erudito e popular - tributária de uma tradição que concebe este último como público cativo de determinadas produções culturais - para uma reflexão acerca dos diferentes significados e/ou sentidos que esta dita cultura popular atribui aos elementos que compõe seu modus vivendi, a partir de sua condição histórica.

As teorias que definem a cultura popular pela sua autonomia ou aquelas que a dimensionam pela sua dependência à cultura dominante são criticadas por Chartier na medida em que ele admite a presença concomitante dessas duas dimensões na cultura popular, contudo numa perspectiva conflituosa em que 
estaria caracterizado o "espaço" entre o instituído e o vivido. A noção de um interstício entre a norma e a prática constitui a baliza que dá suporte ao conceito de apropriação, tão caro à história cultural, pois almeja entender como se dão os usos e interpretações conferidos a determinados bens simbólicos, circunscrita aos grupos sociais que lhes são correspondentes, mas, também, e sobretudo, põe em relevo as apropriações singulares, de objetos e normas que circulam socialmente, produzidas em distintos segmentos sociais. "Em toda sociedade, as formas de apropriação dos textos, dos códigos, dos modelos compartilhados são tão ou mais geradoras de distinção que as práticas próprias de cada grupo social” (CHARTIER, 1995, p. 184).

Roger Chartier defende a idéia de que compreender o sentido dessas apropriações - que constituem o caminho para se traçar as diferenciações entre erudito e popular - significa ainda romper com a noção de continuidade histórica, apresentada pelos teóricos que concebem um marco cronológico para caracterizar a fase áurea da cultura popular e sua posterior (por vezes irredutivel) decadência.

Nessa perspectiva, admitir as diferentes leituras que o "popular" estabelece com esses arcabouços simbólicos e normativos, é também conceber que os sujeitos que o compõem não tomam parte de um fio que supostamente conduzia a (à) História. Pelo contrário, eles possuem lugar no tempo e no espaço, cada grupo social ou momento diferenciado torna-se possivel perceber usos e apropriações próprios.

Foram as ponderações de Roger Chartier e de Carlo Ginzburg que permitiram construir um esforço de compreensão histórica da atuação leiga na difusão da fé protestante no interior do Ceará. Por certo há outras proposições válidas, afinal, a História é um campo de possibilidades infindas, mas foram as reflexões destes historiodores que apresentam uma maior operacionalidade na medida em que apontam para impossibilidade de uma "cultura popular" concebida a priore, já que o centro de suas ideias reside não na emissão de valores e produtos culturais, mas em suas formas de circulação, recepção e recriação.

Se não ensinam um método, Chartier e Ginzburg apontam um caminho; fornecem elementos para se pensar a cultura e a sociedade, e a impossibilidade de as concebermos de forma estática. Como dar sentido à pluralidade? Como pôr em diálogo histórias com destinos diferentes? Não podemos apenas somar 
individuos buscando explicar a sociedade, ou práticas para definir a cultura. Muito menos deduzir um do outro. Estes são desafios que se impõem ao historiador.

Talvez estejamos caminhando para um vir-a-ser constante, de infinitas possibilidades; o exercício da liberdade como nos lembra Revel (REVEL, 1999), onde social é construído ao mesmo tempo em que o objeto e o método num jogo que somente no seu desenrolar revela suas regras, pelo que a história só pode ser pensada como relação e experiência. Eis aí seus sentido e concretude.

Dessa forma, a produção do saber histórico, realizada na e pela narrativa, deve ser compreendida como resultado de um jogo de tensões entre as evidências do passado, fontes, e a ação interpretativa do historiador, prenhe de suas experiências sociais e psicológicas. Mediatizando esse conflito, há a Teoria, a qual é sempre uma opção política, de visão de mundo, o que reforça o entendimento de que o trabalho do historiador é, antes de tudo, um ato criativo.

De um lado o sr. João Porfírio Varela, que, possuindo uma formação longa e sólida na doutrina presbiteriana, tornou-se um evangelizador com um maior conhecimento sobre a liturgia dos ritos celebrados pela igreja presbiteriana, estabelecendo uma liderança alinhada com expectativas dos pastores e presbiteros; do outro lado o sr. Francisco Sousa, crente recém converso, tem sua atuação à frente da Congregação Ebenézer fortemente marcada pela tradição católica de que é tributário. São ambos exemplos da complexidade e da pluralidade da apropriação cultural, como a define Roger Chartier.

A expansão do protestantismo pelo sertão cearense, pelas mãos dos pastores e líderes leigos presbiterianos, deve, então, ser compreendida não como a simples introdução de uma nova religião, mas como uma experiência de reinvenção dessa nova religião

Foi com base nessa diversidade de agentes e práticas, marcada por tensões e conflitos, recuos e avanços, que a expansão do protestantismo pelo interior do Ceará foi se construindo, a um só tempo modificando a religiosidade e o comportamento dos que se convertiam e sendo também modificado por inovações que estes traziam, num exercício dinâmico e conflituoso de adequação de sujeitos a uma prática e dessa prática aos seus sujeitos. 


\section{Referências bibliográficas}

CAMPINA, Maria da Conceição. Voz do Padre Cícero e outras memórias. São Paulo: Edições Paulinas, 1992.

CHARTIER, Roger (org.) Práticas de leitura. São Paulo: Estação Liberdade, 1996.

CHARTIER Roger. "Cultura popular: revisitando um conceito historiográfico" In: Revista de Estudos Históricos.vol. 08, n 16. Rio de Janeiro: FVG, 1995.

CORTEZ, Natanael. Dois tributos: a Deus e a César.Forteleza: mimeo, 1965.

DELLA CAVA, Ralph. Milagre em Joaseiro. $2^{\mathrm{a}}$ ed., Rio de Janeiro: Paz e Terra, 1977.

ELIADE, Mircea. O Sagrado e o Profano. São Paulo: Martins Fontes, 1999.

GINZBURG, Carlo. O queijo e os vermes. São Paulo: Companhia das Lestras, 1987

HAHN, Carl Joseph. A história do culto protestante no Brasil. São Paulo: ASTE, 1989

HOONAERT, Eduardo. Formação do catolicismo no brasileiro (1550-1800). Petrópolis: Vozes, 1974.

LEMOS, Carlos. Casa paulista.São Paulo: Edusp, 1999.

MENDONÇA, Antônio Gouveia. O celeste porvir: a inserção do protestantismo no Brasil. São Paulo: ASTE, 1995.

REVEL, Jacques. A inversão da sociedade.Lisboa: Difel, 1989.

RIBEIRO, Boanerges. A igreja presbiteriana da autonomia ao cisma. São Paulo: Livraria o Semeador, 1987.

SILVA, Rosimeire da. Apelo ao sagrado: o processo de adesão ao protestantismo em Caruaru - PE. Caruaru: Express Graf. / Edições Fafica, 2000.

SPINK, Peter. Análise de documentos de domínio público. In: SPINK, Mary Jane (org.). Práticas discursivas e produções de sentido no cotidiano: aproximações teóricas e metodológicas. São Paulo: Cortez, 1999, pp. 123-152.

VERISSIMO, Francisco Salvador \& BITTAR, William.500 anos da casa no Brasil. Rio de Janeiro: Ediouro, 1999.

VIEIRA JUNIOR, Otaviano. A família na Seara dos sentidos: domicílio e violência no Ceará (1750-1850), Tese de doutorado. São Paulo: USP, 2002.

VIGARELLO, Georges. "O trabalho dos corpos e do espaço” in: Revista Projeto História $n^{o}$ 13. São Paulo: PUC-SP, 1996, pp. 07-20.

WEBER, Max. A ética protestante e o espírito do capitalismo. $9^{\mathrm{a}}$ ed., São Paulo: Pioneira, 1994. 


\footnotetext{
${ }^{i}$ Até 1938 os estados que hoje compõe a chamada região Nordeste do Brasil eram parte da Região Norte.

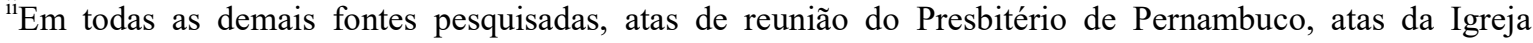
Presbiteriana de Fortaleza e o jornal Imprensa Evangélica, mencionam apenas a existência de cinco igrejas no Campo Missionário de Pernambuco, em 1891: a Igreja Presbiteriana do Recife, a Igreja Presbiteriana de Garanhuns (PE) a Igreja Presbiteriana de Goiana (PE), a Igreja Presbiteriana da Paraíba e a Igreja Presbiteriana de Maceió.

iii Importa lembrar, no entanto que estudos clássicos sobre a evangelização protestante nas cidades do Rio de Janeiro e de São Paulo no século XIX, evidenciam que nelas os pobres, se não foram o público preferencial dos missionários estadunidenses, foram os que primeiro deram uma resposta positiva à sua propaganda. Sobre isso ver: MENDONÇA, Antônio G. O Celeste porvir: a inserção do protestantismo no Brasil(1995) e RIBEIRO, BOANERGES, Protestantismo no Brasil monárquico(1987).

iv Os trechos de fontes primárias em língua portuguesa foram transcritos tal e qual foram escritos originalmente. Compreendo que respeitar a grafia original da fonte é fundamental preservar sua originalidade e seu potencial de evidência histórica.

v Este é o termo com o qual são denominados os líderes leigos das congregações do interior do Ceará e na periferia da capital nos documentos oficiais da Igreja Presbiteriana de Fortaleza.
}

Recebido em 05/03/2021

Aceito para publicação: 09/04/2021 


\title{
Congregacionais e a Renovação Espiritual no Nordeste
}

\author{
Congregationalists and Spiritual Renewal in Brazilian Northeast region
}

Heitor Lamartine*

https://doi.org/10.29327/256659.12.2-6

\section{Resumo:}

Em meados de 1960, um clima de efervescência religiosa se alastrou por igrejas protestantes Brasil afora, conclamando uma renovação espiritual, que ganhou corpo através do Movimento de Renovação Espiritual. Os ventos dessa revitalização religiosa avançaram sobre o Nordeste, alcançando líderes e fiéis de várias denominações. No contexto nordestino, os batistas e congregacionais cumpriram importante papel para consolidação e difusão dessa tendência. Neste artigo, apresentamos um panorama histórico e sociológico acerca da renovação de segmentos do congregacionalismo e suas tensões na Paraíba e Pernambuco. Para tanto, além da literatura especializada consultada, realizamos pesquisa documental e entrevistas. Pretendemos, assim, sublinhar a importância desse movimento religioso para compreensão de facetas do protestantismo brasileiro e suas interfaces.

Palavras-chave: Congregacionalismo. Pentecostalização. Protestantismo. Renovação religiosa.

Abstract:

In the mid-1960s, an atmosphere of religious effervescence spread to Protestant churches throughout Brazil, calling for a spiritual renewal, which took shape through the Spiritual Renewal Movement. The winds of this religious revitalization advanced over the Brazilian Northeast region, reaching leaders and followers of various denominations. In the Northeastern context, Baptists and Congregationalistsplayed an important role in consolidating and spreading this trend. In this article, we present a historical and sociological overview of the renewal of segments of Congregacionalism and its tensions in Paraiba and Pernambuco states. Therefore, in addition to the specialized literature consulted, we have carried out documentary research and interviews. We intend, therefore, to underline the importance of this religious movement for the understanding of facets of Brazilian Protestantism and its interfaces.

Keywords: Congregacionalism; pentecostalization; Protestantism; religious renewal.

\section{Introdução}

Desde a inserção do Movimento Pentecostal no Brasil, ${ }^{1}$ a relação entre protestantes 'históricos' e pentecostais foi, na maior parte do tempo, marcada por

"Mestre em Ciências Sociais pela Universidade Federal de Campina Grande (UFCG). E-mail: heitor_lamartine@outlook.com. 
conflitos e tensões. Mas, em meados do século passado, as disputas entre esses segmentos religiosos começaram a arrefecer no país. Nessa época, o pentecostalismo teve amplo suporte dos seus fiéis para uma nova dinâmica de crescimento. Conforme Francisco C. Rolim (1985, p. 23), "não fosse a expansão pentecostal acelerando-se a partir da década de 1950, o protestantismo [leia-se, campo evangélico] não teria o crescimento que vem mostrando". A expansão pentecostal, certamente, contribuiu para reconfigurações no campo evangélico brasileiro.

Tal êxito do pentecostalismo no Brasil esteve associado com mudanças que a sociedade brasileira atravessou na esfera cultural, econômica, política, social e religiosa: crescimento demográfico nacional, intensificação das migrações internas e êxodo rural, urbanização e formação das periferias em grandes e médias cidades, retomada da industrialização do país, são alguns dos fatores que, direta e indiretamente, tiveram ressonância no cenário religioso brasileiro, contribuindo para enraizamento, crescimento e expansão pentecostal.

Deixando de ser uma minoria religiosa, os pentecostais vêm se tornando maioria numérica no campo evangélico e, também, frente a outras religiões. Como observam Leonildo S. Campos e Benjamín F. Gutiérrez (1996, p. 7), o Movimento Pentecostal "passou do rodapé da história religiosa e cultural para ser um concorrente pela hegemonia com o catolicismo no campo religioso brasileiro". Entretanto, seu avanço não se deu apenas em termos de adesões denominacionais; aliás, esse movimento religioso rompeu barreiras e transpassou limites do denominacionalismo existente.

O pentecostalismo converteu-se em um eminente paradigma de teologias e práticas religiosas para o cristianismo contemporâneo em várias nações e, em especial, no Brasil. Em meados do século XX, vimos ocorrer uma intensa assimilação de bens simbólicos pentecostais pelas principais denominações protestantes e até por setores católicos. Esse processo foi encarado de variadas maneiras, ora como revigoramento religioso, outra como ameaça à ortodoxia e identidade protestantes, causando situações paradoxais de renovação religiosa e crises denominacionais, retomada de crescimento e cismas.

Nessa dinâmica, o protestantismo brasileiro ${ }^{2}$ sofreu metamorfoses. Territórios confessionais foram recompostos e as interações entre indivíduos, instituições e universos simbólicos do campo evangélico sofreram profundas alterações, gestando o que estudiosos têm denominado de pentecostalização. Esse fenômeno 
sociorreligioso adquire maior expressão e visibilidade com o advento do Movimento de Renovação Espiritual ${ }^{3}$, que tomou diversas denominações e igrejas protestantes do país sob o anseio de revitalização religiosa.

Considerando essas questões, empreendemos pesquisa. Sob um prisma histórico-sociológico, nos empenhamos em analisar a gênese, desenvolvimento e desdobramentos atuais do Movimento de Renovação Espiritual Congregacionalista. Em correspondência com a abordagem adotada, realizamos um trabalho de pesquisa bibliográfica e documental, bem como, uma série de entrevistas com pastores e líderes congregacionais.

No decurso de nosso estudo exploratório, observamos que livros e trabalhos acadêmicos versando sobre essa temática possuem raras menções acerca dos impactos da renovação no congregacionalismo brasileiro. Todavia, esse segmento foi igualmente alcançado pelo Movimento de Renovação Espiritual, como o foram batistas, presbiterianos e metodistas. Prova disto é que no final da década de 1960, um grupo de pastores e fiéis congregacionais da Paraíba, Pernambuco e outros estados do Nordeste, seguiram pelas trilhas do Movimento Renovacionista que estava acontecendo no Brasil. À medida que o fenômeno pentecostalizante se difundiu nos círculos congregacionais, sobrelevaram-se as tensões, acarretando uma cisão denominacional e gerando dissidências nas igrejas locais.

Porém, não tardou para que os pastores e as Igrejas Congregacionais adeptas da renovação espiritual na região Nordeste - ou mesmo, pentecostalizadas - se reagrupassem denominacionalmente por meio da Aliança das Igrejas Evangélicas Congregacionais do Brasil (AIECB). Entremeios, surge a Igreja Evangélica Congregacional Vale da Bênção de Caruaru, que se tornaria baluarte e núcleo irradiador do congregacionalismo renovado de Pernambuco ao estrangeiro.

\section{O Movimento de Renovação Espiritual}

Por volta dos anos 1940, líderes e grupos vinculados à Igreja Metodista do Brasil começaram a pregar sobre a necessidade de um reavivamento. Em busca de uma efervescência religiosa semelhante àquela dos grandes avivamentos na Inglaterra e nos Estados Unidos do século XVIII. Esses arautos reavivalistas abriram caminho para um processo de assimilação de crenças e práticas pentecostais por parte das denominações e igrejas protestantes brasileiras (CAMPOS JÚNIOR, 2009). 
Nessa mesma época, a missionária Rosalee M. Appleby defendeu que, para superar a estagnação e frieza espiritual da comunidade batista em Minas Gerais e no Brasil, era necessária uma renovação espiritual. No decorrer dos anos, segundo Reinaldo A. Pereira, as pregações e escritos da senhora Appleby influenciaram pastores e líderes que se envolveram numa verdadeira campanha de revitalização religiosa da denominação batista.

Esta tendência logo se espalhou pelas igrejas batistas, congregacionais, presbiterianas e metodistas - não desconsiderando sua penetração entre os luteranos e católicos. Por meio de congressos, estudos bíblicos, folhetins, livretos, pregações, programas de rádio, reuniões de oração se propugnava a urgência de um reavivamento, uma renovação religiosa para o protestantismo brasileiro. Os pastores batistas José Rego do Nascimento e Enéas Tognini estão entre os principais responsáveis pela difusão da mensagem renovacionista pelo país. Na década de 1960, essa tendência ganha corpo no Movimento de Renovação Espiritual, através de encontros nacionais e regionais. Viajando pelo Brasil, os líderes renovacionistas pregavam sobre a importância da doutrina do Espírito Santo, a crença na atualidade dos dons espirituais e testemunhavam suas experiências pneumáticas entre seus confrades batistas, congregacionais, metodistas e presbiterianos - com um discurso religioso muito próximo e até semelhante ao dos pregadores pentecostais.

Essa onda carismática não representou apenas uma revitalização religiosa, como também provocou alterações no modelo de religiosidade, tradicionalmente, adotado pelas igrejas protestantes de missão no país ${ }^{4}$. Assim como o Movimento Pentecostal, a renovação espiritual tornou-se um movimento com força suficiente para criar novas realidades eclesiásticas, reestruturar teologias e substituir práticas cristalizadas por novas formas de crer, praticar e experimentar a fé protestante.

Após meio século de acirrados conflitos com os pentecostais, alas do protestantismo histórico e do catolicismo começaram a assimilar crenças e práticas que, outrora, foram caracteres quase exclusivos do pentecostalismo. Culminando no que o cientista social e teólogo Bernardo Luis Campos Morante (2016) chamou de "movimentos carismáticos não-pentecostais". Propositadamente ou não, os protestantes que transpuseram o abismo que os separava dos pentecostais, aproximaram-se e interiorizaram elementos do Movimento Pentecostal. Dessa 
maneira, acabaram redefinindo os termos das conexões e trocas simbólicas entre o protestantismo e o pentecostalismo.

Grosso modo, o movimento renovacionista tinha por objetivo revigorar as comunidades do protestantismo de missão, revitalizar a experiência religiosa dos fiéis e angariar novos conversos. No entanto, Thiago Moreira (2016, p. 22) observa que,

\footnotetext{
O advento desta expansão pentecostal, ou melhor, da experiência pentecostal em meio às igrejas protestantes tradicionais trouxe à baila novas formas de experenciar sua religiosidade que para uns seria uma forma mais livre, emocional e viva, para outros, uma forma herética, irracional e infantil. Assim, a questão do batismo no Espírito Santo e as possiveis manifestações que lhe seriam características apresentam-se como um desafio teológico e institucional $[\ldots]$.
}

Esse fenômeno sobreveio às searas protestantes como um tsunami, em certo sentido, 'invadindo-as'. Não obstante, pastores e leigos contrários aos 'excessos pentecostais' quiseram purgar suas denominações e comunidades dessa 'invasão pentecostal'. De modo que a emergência do Movimento de Renovação Espiritual foi acompanhada por acaloradas discussões em concílios denominacionais e assembleias locais, várias dessas resultando em divisões institucionais e comunitárias. Na tentativa de preservar as tradições denominacionais, convenções de ministros e reuniões extraordinárias foram acionadas para intimar pastores e crentes adeptos da renovação espiritual.

Muitos desses indivíduos foram expulsos e outros tantos, espontaneamente, decidiram deixar suas comunidades, por não abrirem mão das crenças e da experiência carismática. Os dissidentes se mobilizaram, dando origem às chamadas igrejas renovadas, que também formaram redes de filiação à semelhança de denominações protestantes e pentecostais já estabelecidas.

\section{E os ventos da renovação sopraram sobre os protestantes nordestinos}

Enfrentando os desafios de uma recomposição denominacional, diversos pastores e igrejas congregacionais do Nordeste também foram afetados pelo Movimento de Renovação Espiritual. Seguindo a narrativa oficial, por volta de 1959, um clima de efervescência religiosa com tonalidades pentecostais tomou a $1^{\text {a }}$ Igreja Congregacional de João Pessoa, no estado da Paraíba. A partir da pregação 
do pastor metodista Dorival Rodrigues Bewlke, por ocasião da festividade da União Auxiliadora Feminina, aquela comunidade viu aumentar o número de "conversões, de mudança de hábito em muitos membros da igreja. A Mocidade era ativa, a Auxiliadora atuante, a Escola Dominical dinâmica, o Evangelho pregado com autoridade, almas sendo salvas e o Reino de Deus se expandindo" (SANTOS, 2006, p. 231).

Repetindo padrões observados em igrejas protestantes impactadas pela renovação espiritual, no ano de 1962, cerca de 80 fiéis deixaram essa Igreja Congregacional de João Pessoa para se integrarem à Assembleia de Deus, causando forte abalo naquela comunidade. Mesmo com a baixa de membros, os congregacionais permaneceram envoltos numa aura de renovação religiosa que, mais tarde, contagiou outras igrejas congregacionais paraibanas e pernambucanas.

Segundo o pastor e memorialista Geraldo Batista dos Santos (2006, p. 231),

[...] o grupo remanescente, na liderança do pastor Jônatas Ferreira Catão, não desanimou, nem tergiversou. Pelo contrário, continuou exercendo o ministério da oração, a prática de uma vida à disposição do Senhor da Obra: evangelizando e servindo. Deus honrou, abençoou e triplicou a membresia da igreja, tornando-a forte numérica e espiritualmente. Muitos desses irmãos tiveram vidas renovadas, com a bênção do batismo com o Espírito - inclusive o pastor Catão -, exercendo dons, ganhando almas, vivendo plenamente o Evangelho. Desde, então, o reverendo Jônatas Ferreira Catão e sua igreja promoveram uma busca pelo "avivamento espiritual".

Enquanto isso, na capital pernambucana, os batistas também se engajaram no Movimento de Renovação Espiritual. Em 1961, o reverendo José Rego do Nascimento realizou uma série de conferências em igrejas e seminários teológicos do Recife, por ocasião do Congresso da Juventude Batista Pernambucana. O evento reuniu pastores, lideranças leigas e jovens de várias denominações para ouvir a pregação desse 'profeta' do renovacionismo.

Segundo Rosivaldo de Araújo (2013, p. 32),

O pastor José Rego voltou para Belo Horizonte, porém muitos segmentos evangélicos do Recife foram incendiados pelo poder de Deus. Ninguém mais conseguia viver aquela vida antiga, morna, acomodada e sem unção. Os batismos no Espírito Santo começaram a se suceder naquelas igrejas tradicionais e conservadoras, entre pastores, líderes e os crentes em geral. 
A Igreja Batista de Casa Amarela tornou-se outro centro irradiador da renovação protestante no Nordeste. A partir dela e da influência de seu pastor, Rosivaldo de Araújo, várias igrejas protestantes de Pernambuco começaram a promover reuniões de oração e vigílias, os sermões pregados adquiriram tons avivalistas e cultos eram marcados por pessoas se convertendo, brados de aleluia e glória a Deus, fiéis sendo batizados com o Espírito Santo, falando n'outras línguas, tendo visões, declarando profecias ou sendo curados miraculosamente à semelhança dos pentecostais.

Nesse período, as articulações e contatos entre os líderes renovacionistas do país se tornaram mais frequentes. Pastores e igrejas renovadas buscavam estar sincronizados com o Movimento Renovacionista em âmbito nacional e regional. Os batistas protagonizaram Encontros Nacionais e Regionais de Renovação Espiritual, realizados anualmente em diferentes estados, contando até com a participação de pregadores pentecostais, como o bispo Robert McAlister. Era um momento em que se buscava esclarecimento das doutrinaseexperiências pentecostais, bem como, sobre o processo de interiorização e incorporação à teologia e práxis do protestantismo tradicional (ARAÚJO, 2013).

Essa disposição do campo evangélico permitiu maior fluxo e contatos entre fiéis de diferentes denominações e, consequentemente, de trocas simbólicas. Os eventos interdenominacionais realizados serviram como espaços desterritorializados, por não estarem sujeitos ao domínio de denominações ou igrejas específicas. Conforme Araújo (2013), o caráter interdenominacional do Movimento de Renovação Espiritual entre os nordestinos, culminou na criação do Comitê de Avivamento do Nordeste, reunindo batistas, congregacionais, metodistas e presbiterianos independentes.

Entremeios, o pastor Jônatas Ferreira Catão, acompanhado por outros pastores, líderes leigos e fiéis congregacionais aderiram de vez ao Movimento Renovacionista, participando dos encontros interdenominacionais e disseminando a mensagem da renovação nas suas comunidades.

Conforme Santos (2006, p. 232),

Nos idos de 1964 surgiu no seio dos batistas o Movimento de Renovação Espiritual e muitas igrejas foram sacudidas pelo poder do Espírito Santo para a realização de uma grande obra. Anossa igreja se identificou muito bem com a linha de Renovação Espiritual, porque liderada por homens de Deus de muito conceito e de bom testemunho, a exemplo dos pastores José Rego do Nascimento, Enéas Tognini, Rosivaldo de Araújo, Josué Santana [...] Havia ale- 
gria no meio do povo de Deus e as igrejas promoviam encontros de renovação, com o envolvimento de muitos pastores, líderes, cantores e igrejas. Era uma festa constante, com o povo arregimentado, orando, cantando e vivendo o evangelho com muita intensidade. Como dissemos, o volume maior de igrejas era do segmento batista, entretanto, na Paraíba, tínhamos na Igreja Congregacional de João Pessoa o seu maior expoente, o epicentro do movimento, com uma atuação marcante na capital, com reflexos em toda a região.

As conexões interdenominacionais foram imprescindiveis para fortalecimento do emergente movimento e, também, para o processo de interiorização teológica, assimilação e tradução cultural dos bens simbólicos e práticas pentecostais pelos protestantes. A natureza interdenominacional do Movimento Renovacionista permitiu que teólogos renomados, como Enéas Tognini, contribuíssem para formulação doutrinária das crenças e práticas assimiladas, constituindo assim uma importante etapa da legitimação para as igrejas renovadas.

A recomposição do universo simbólico congregacional, assim como dos demais grupos carismáticos, precisava de aportes na própria tradição congregacionalista, sem a qual seria inviável manter a identificação dos renovacionistas com o congregacionalismo.

Segundo Moreira (2016, p. 35),

Para os adeptos da renovação espiritual o objetivo era "renovar", ou seja, partir de algo que já estava posto, um protestantismo que era considerado "frio" e com uma espiritualidade escassa (ou até ausente): "igrejas que existem, mas que dormem embaladas pelo comodismo e pela inatividade". Tratava-se de conduzir tal protestantismo a uma dimensão experiencial que promovesse o despertar da espiritualidade tal como na igreja primitiva (era apostólica), um "retorno ao Pentecostes", e não de inovar.

A adesão desse segmento congregacionalista ao Movimento de Renovação Espiritual pode ser considerada, primeiramente, como uma consequência do reconhecimento da vivência e da experiência pentecostal-carismática de pastores, fiéis e igrejas congregacionais. Mas, ainda há dois aspectos interessantes para pensar acerca dessa abertura para pentecostalização.

Partindo de alguns insights pontuados por Enéas Tognini (1986), sublinhamos que a aceitação da renovação espiritual, se não assimilada pelo protestantismo brasileiro, poderia ter como resultado imediato a transferência de fiéis e até pastores para denominações e igrejas pentecostais. Outro desdobramento 
dessa decisão diz respeito ao modo como protestantes históricos continuariam lidando com um novo modelo de religiosidade oferecido no mercado religioso - a saber, aquele que prometia experiências mais emocionais com o sagrado, com destaque para o usufruto dos dons do Espírito Santo.

Olhando por esse prisma, ao aceitar os princípios da renovação espiritual, os líderes congregacionais estariam mudando os rumos do congregacionalismo brasileiro. Aqueles que o fizeram assimilaram diversos elementos simbólicos do Movimento Pentecostal que se tornaram temas e objetos transversais do universo religioso das igrejas congregacionais renovadas, condicionando suas doutrinas, representações, simbolos, práticas, enfim sua teologia, religiosidade e experiência religiosa.

\section{Forjando uma Aliança Congregacional}

Conforme Manoel B. Santana Filho (2011, p. 5), havia "um desejo ardente e também sincero de um avivamento espiritual no meio das igrejas da União"5. Por outro lado, existia uma preocupação em conservar a tradição congregacionalista iniciada pelo missionário Robert Reid Kalley, afim de preservar seus princípios teológicos e, principalmente, eclesiásticos.

No entanto, assim como aconteceu com outras denominações protestantes, a renovação espiritual entre os congregacionais desencadeou reações adversas. A proliferação das crenças e práticas renovacionistas no interior da União Congregacional, despertou a oposição de um grupo de pastores, dada sua semelhança com o universo simbólico pentecostal. Para o qual, a renovação espiritual representava uma ameaça à ortodoxia e ao modelo de culto congregacional. As práticas relacionadas com a renovação espiritual foram consideradas por alguns como antagônicas ao ethos congregacional e à teologia reformada-kalleyana. Logo, os líderes e fiéis renovacionistas seriam estigmatizados como facciosos que ensinavam 'heresias pentecostais', degenerando a tradição protestante e, mais especificamente, congregacional.

No mês de junho de 1967, a Igreja Evangélica Congregacional de Patos, Paraíba, pastoreada pelo reverendo José Quaresma de Mendonça, sediou dois congressos, um organizado pelo departamento feminino e outro pela juventude. As preleções do missionário Gerson Barbosa de Menezes foram acompanhadas de conversões, confissões de pecados e ‘batismos com o Espírito Santo'. A reper- 
cussão desses eventos parece ter sido o estopim para que o setor congregacionalista conservador combatesse abertamente o renovacionismo entre os congregacionais, numa ação de feitios inquisitoriais (SANTOS, 2006).

Foi então convocado o $18^{\circ}$ Concílio Geral (Extraordinário) da União Congregacional, sediado em Feira de Santana, estado da Bahia, que se realizaria no final do mês de julho. Segundo a versão dos renovacionistas, a pauta principal da reunião foi a questão da renovação espiritual entre os congregacionais. Uma comissão especial havia sido encarregada de apresentar um relatório sobre o assunto aos participantes da assembleia. Para Santos (2006, p. 235),

O documento era um verdadeiro libelo acusatório às igrejas que estavam trabalhando de forma avivada e dependente de Deus: taxaram-nos de pentecostais de última hora, de xangozeiros, de embusteiros, de promotores de baixo espiritismo, de hereges, de anátemas, provocadores da desordem no culto, de profetas falsos, entre outros adjetivos.

O parecer da comissão recomendava, então, a exclusão de igrejas e pastores da fraternidade denominacional. Durante o concilio foi vetado o direito de resposta aos renovacionistas, que sequer tiveram tempo para se articular com os membros da assembleia antes da votação. Ao final da reunião, foi deferida a exclusão de sete igrejas filiadas da Paraíba, Pernambuco e Rio Grande do Norte, além dos seus respectivos pastores. Foram excluídos, assim, os pastores Jônatas Ferreira Catão, José Quaresma de Mendonça, Isaías Correia dos Santos, Moisés Francisco de Melo, Raul de Souza Costa, João Barbosa de Lucena e Roberto Augusto de Souza.

Partindo das considerações de Pereira (2011), entendemos que esse 'processo inquisitorial' não foi um ato isolado, tampouco uma reação somente aos renovacionistas desligados naquela ocasião. Consistiu numa tentativa de legitimação da religiosidade tradicional - e, cessacionista -, ao mesmo tempo, era uma via para interromper o processo de pentecostalização que estava em curso naquela e em outras denominações protestantes brasileiras. Esse cerceamento religioso, construído nos meandros do poder, "fez com que a prática da vigilância tivesse equivalência com a prática persecutória e inquisitória” (PEREIRA, 2011, p. 92), comum na história protestante e, particularmente, no contexto do Movimento de Renovação Espiritual do protestantismo brasileiro. 
O congregacionalismo renovado também foi encarado como uma degeneração doutrinária e, consequentemente, da identidade congregacionalista. Para aqueles que se arrogaram como representantes da tradição confessional, a renovação espiritual seria uma profanação dessa ortodoxia.

Como explica Carlos H. P. Souza (2013, p. 13),

Para estes grupos a pentecostalização representa a influência da crença pentecostal no reforço de concepções mágicas do mundo nas igrejas históricas. Isto ocorreria em consequência da predominância de concepções encantadas fortemente presentes no "ambiente pentecostal" o que explica o fenômeno ocorrido nas igrejas históricas.

Nesse sentido, a pentecostalização não apenas engendrou mudanças na cultura religiosa congregacional, como também desvelou disputas que estavam germinando alguns anos antes, desde a inserção pentecostal no país e assimilação de tendências carismáticas por outras igrejas protestantes. Essas mudanças davam margem para conflitos internos que irromperam com inúmeras cisões denominacionais decorrentes da questão pentecostalizante. Pôr em suspeição, estigmatizar, perseguir e excluir foram instrumentos para atacar e, se possivel, extirpar o mal que incomodava e ameaçava o establishment protestante e, por extensão, congregacionalista.

Assim foi com os batistas renovados que, mediante a exclusão da Convenção Batista Brasileira fundaram a Convenção Batista Nacional. Não seria diferente com os congregacionais, que já contavam com um corpo de pastores instituídos e templos disponíveis para reunir os fiéis adeptos da renovação espiritual.

O concílio de Feira de Santana refletia a tentativa de impedir o avanço da pentecostalização e conter os agentes pentecostalizantes que trabalhavam para renovar o congregacionalismo brasileiro. Diante da resolução daquela assembleia, restou aos congregacionais renovacionistas o mesmo caminho que outros protestantes renovados excluídos, fundar uma nova denominação.

Conforme Santos (2006, p. 237), a sugestão de "reunir os excluídos num grupo organizado, com características denominacionais, com estatuto, regimento interno, diretorias" partiu do pastor Jônatas Ferreira Catão. Ele se tornou principal agente na tarefa de arregimentar pastores e igrejas para formar uma nova denominação congregacionalista. Com seu carisma pessoal e capacidade de arti- 
culação não lhe foi dificil cumprir tal missão. Visitas foram realizadas aos líderes e igrejas congregacionais que comungavam dos ideais e práticas renovacionistas que, após desligarem-se da União, juntaram-se ao grupo excluído.

Em 13 de agosto de 1967, as delegações das igrejas congregacionais renovadas se reuniram na Igreja Evangélica Congregacional de Campina Grande para discutir sobre a criação de uma nova entidade denominacional que lhes representasse. Dando continuidade ao concílio, no dia seguinte, foi fundada a Aliança de Igrejas Evangélicas Congregacionais do Brasil.

Assim, a Aliança Congregacional foi constituída como organismo denominacional representante das igrejas congregacionais de linha renovada no Nordeste brasileiro, assumindo o papel de difundir, expandir e solidificar o congregacionalismo carismático na região e além. Entusiasticamente, a esposa de um dos líderes renovacionistas congregacionais, d. Iraci Silva de Mendonça (2007, p. 42) relata que

Desde então, as igrejas tomaram grande impulso espiritual. Agora com uma nova visão, na doutrina (com ensinamentos intensivos), na comunhão, no amor, na firmeza, na dedicação, enfim: mais sede de salvação pelas almas perdidas. Foi uma verdadeira revolução espiritual, parecendo até que havia surgido uma nova igreja, que dia-a-dia crescia e se fortalecia.

E, assim como outras denominações do Movimento de Renovação Espiritual que surgiam, os congregacionais renovacionistas cantavam a canção do reverendo Rosivaldo de Araújo: “Ninguém detém é obra santa! Nem Satã, nem o mundo todo podem apagar esse ardor...”.

Mesmo com a recomposição nacional da União das Igrejas Evangélicas Congregacionais do Brasil, em 1969, que tinha o propósito de reunir 'todas' igrejas congregacionais do país em um só órgão denominacional, os renovados permaneceram de fora dos quadros da nova denominação. Escrevendo sobre a história do congregacionalismo brasileiro, os reverendos Salustiano P. César (1983) e Manoel Porto Filho (1997) omitiram o racha com os renovados. No entanto, deixaram nas entrelinhas que os 'autênticos congregacionais' estariam integrados na União Congregacional, como únicos e verdadeiros herdeiros dos pioneiros congregacionais no Brasil. 


\section{No Vale da Bênção: a renovação congregacional na "Capital do Agreste" per- nambucano}

Em fins do século XIX, a cidade de Caruaru, no interior de Pernambuco, recebia além da estação ferroviária da Great Western, os primeiros missionários congregacionais. A despeito dos entraves, a Primeira Igreja Congregacional de Caruaru foi implantada. Entre avanços e percalços, essa comunidade se solidificou e cresceu significativamente, especialmente, sob a liderança do reverendo Júlio Leitão de Melo. Estima-se que, na década de 1960, havia cerca de quinhentos fiéis membros dessa igreja ${ }^{6}$.

Cumpre frisar que desde que se estabeleceram em Caruaru, os congregacionais tiveram de enfrentar o enorme desafio de romper com o monopólio católico, como demonstraram Joyce E. W. Every-Clayton e Araújo (1998). Apesar da predominância do catolicismo, desde 1920, a presença protestante já se fazia notória na sociedade caruaruense. Além dos congregacionais, outras missões protestantes começaram suas atividades na cidade, culminando na fundação da Primeira Igreja Batista (1923), da Primeira Igreja Presbiteriana do Brasil (1927), da Assembleia de Deus (1935), da Igreja de Cristo Pentecostal do Brasil (1947), entre outras.

Convém pontuar que, em meados do século XX, Caruaru despontava no agreste pernambucano como centro gravitacional de comércio, cultura e educação ${ }^{7}$. Jovens, adultos e famílias inteiras, por diferentes motivações, afluíram das zonas rurais e cidades circunvizinhas para a juvenil "Princesa do Agreste". O crescimento demográfico foi acompanhado por profundas mudanças socioculturais, como o desenvolvimento comércio e a indústria local. Sob a onda do desenvolvimentismo nacional, Caruaru recebeu as inovações do cinema, do rádio, da arquitetura e da urbanização, bem como, os colégios ginasiais e as primeiras faculdades da região. Por meio de discursos, imagens e práticas sociais, foi então inventada a "Capital do Agreste".

Essas metamorfoses parecem ter sido acompanhadas por uma intensificação do processo de pluralização do campo religioso local, aliando-se o crescimento urbano, que atraía individuos com a emergência de novas propostas de religiosidade. Como salientou Rolim (1985), os fenômenos de êxodo rural, urbanização, industrialização e migração, frequentemente, têm sido indicados como 
fatores importantes para entendermos o crescimento e a expansão do protestantismo e, sobretudo, do pentecostalismo.

Essa inferência encontra respaldo no fato de que, com menos tempo de atuação na cidade, os assembleianos logo ultrapassaram numericamente a comunidade congregacional e, também, em termos de expansão territorial, contando com três templos da Assembleia de Deus (RODRIGUES,1968).

Essas mudanças, certamente, afetaram na lógica e no funcionamento das igrejas evangélicas da cidade. Assim, é possivel inferir que os pentecostais experimentaram um acelerado crescimento e expansão, no lastro de transformações socioculturais mais amplas. Algo que acreditamos ter contribuído para tornar o ambiente sociorreligioso propício à recepção do Movimento de Renovação Espiritual entre os protestantes caruaruenses e, especialmente, os congregacionais.

Não podemos esquecer que um clima avivalista tomava conta das igrejas congregacionais paraibanas e pernambucanas, das capitais ao agreste. Na medida em que o Movimento Renovacionista crescia com a adesão de pastores e fiéis de várias denominações protestantes, aumentava sua influência, despertando outros tantos para a mensagem renovacionista, que também chegou à capital do agreste pernambucano.

Conforme relata o pastor Anacleto Inácio da Silva ${ }^{8}$, nos idos de 1965, a Primeira Igreja Congregacional de Caruaru recebeu o pastor Josué Santana, importante líder batista do movimento renovacionista na cidade do Recife. Durante sua visita, o reverendo ministrou uma série de estudos sobre despertamento espiritual para os fiéis congregacionais e mensagens evangelísticas nos cultos públicos. Nosso entrevistado acrescentou que

Em 1966 acontece mais um Encontro de Renovação Espiritual, desta feita, na cidade de Recife, tendo como palestrante o reverendo Enéas Tognini. Estiveram presentes a este Encontro vários pastores congregacionais. Posso citar dois, que acredito que tiveram importância, o Roberto Augusto de Souza, que era o pastor da Igreja Congregacional em Casa Amarela em Recife, e o pastor Edgar Leitão de Albuquerque, que era o pastor da Primeira Igreja [Evangélica Congregacional] de Caruaru. Então, esses homens beberam na fonte da renovação. Esses e outros tantos, já vinham há anos atrás buscando um avivamento genuíno, estudando sobre o assunto, orando por isso, não é? Então, por isso que quando o movimento acontece, as portas se abrem no seio congregacional 
para receber o movimento. Era algo que eles já vinham buscando algum tempo atrás. [Acréscimo nosso].

Em janeiro de 1967, a cidade do Recife sediou o IV Encontro Nacional de Renovação Espiritual. ${ }^{9}$ Uma caravana formada por fiéis da Primeira Igreja Congregacional de Caruaru foi organizada pelo presbítero Caetano Antônio da Silva para participar do evento. Ao regressar do encontro, o grupo se reuniu para orar no pátio da residência do presbítero citado. Depois daquela primeira reunião, outras se sucederam. Geralmente, ocorriam após os cultos noturnos da referida igreja, estendendo-se pela madrugada.

Daniel Tenório Siqueira (2007, p. 15) registra ainda que,

[...] aqueles irmãos passam a reunir-se regularmente naquele local, onde, certo dia, diante da visitação poderosa do Espírito Santo, o irmão José Braz declarou: "Isto é um vale de bênção!". De fato, aquela declaração expressava na íntegra, a nova e indizivel experiência que aqueles irmãos estavam vivendo. Desde então, o pátio da casa do presbitero Caetano passou a ser chamado de "VALE DA BÊNÇÃO”.

A exclamação daquele fiel, consciente ou inconscientemente, reportou-se ao tema do IV Encontro Nacional de Renovação Espiritual, Juntos no Vale da Bênção, do qual tinha participado o grupo simpático à renovação espiritual ${ }^{10}$. Essa experiência hierofânica do "vale de bênção" foi, ao mesmo tempo, transformadora da religiosidade daqueles congregacionais e fundante para o movimento renovacionista local que mais tarde daria origem à Primeira Igreja Evangélica Congregacional Vale da Bênção. O grupo carismático detinha, a partir de então, um fundamento de legitimidade pela vinculação a um poder extemporâneo outorgado pela própria divindade, o Espírito Santo e, também, baseada no princípio da sola Scriptura (SANTOS, 2014). De modo geral, a expressão "vale da bênção" seria tomada como símbolo da ala carismática congregacional.

Araújo (2013) relata que chegou a participar de algumas daquelas reuniões no pátio do presbítero Caetano. Ele enfatiza a presença de pessoas de outras denominações, desde assembleianos até batistas afeiçoados aos ideais renovacionistas. Também era comum encontrar pessoas não evangélicas, algumas das quais acabavam se convertendo à fé protestante. Dentro de pouco tempo, esses cultos já contavam com aproximadamente quarenta pessoas. 
Devido à continuidade das reuniões carismáticas, a liderança congregacional caruaruense propôs, em reunião ordinária, a convocação para os fiéis retornarem, caso contrário, seriam excluídos do rol de membros da Igreja Congregacional.

Siqueira $(2007$, p. 13) nos informa que,

O pastor Edgard Leitão de Albuquerque (na época pastor da Primeira Igreja Evangélica Congregacional) tentou contornar a situação, e, em uma reunião ordinária presidida por ele, no dia 06 de agosto de 1967, na qual foi determinada uma data de retorno dos 38 irmãos à igreja. Os que não retornassem estariam automaticamente desligados do rol de membros da igreja. O tempo determinado se passou, e na reunião do mês seguinte, 03 de setembro de 1967, houve o retorno dos irmãos José Brás de Araújo, José Antônio de Oliveira e a irmã Maria José de Oliveira. Os outros foram desligados do rol de membros da igreja, em um total de 35 irmãos $[\ldots]$.

O grupo renovacionista se afastou voluntariamente da Igreja Congregacional de Caruaru, deixando a tutela religiosa do reverendo Edgard Leitão. Como observou Antônio G. Mendonça (2004, p. 33), "quanto mais rígida e sujeita a doutrinas estabelecidas e consolidadas for uma instituição religiosa, mais sujeita estará a divisões ocasionadas pela necessidade de liberação do sagrado". Diante da impossibilidade de perpetuar seus vínculos, a criação de uma nova comunidade com elementos da teologia reformada-kalleyana e eclesiologia congregacional acrescida das ênfases pentecostais-carismáticas seria a via para que o grupo renovacionista se reconhecesse como mantenedor da tradição congregacionalista brasileira. Além do mais, a concepção congregacionalista de igreja, como corpo de fiéis reunidos localmente, dava margem para formação do novo agrupamento sem maiores dificuldades. Dos excluídos, 28 pessoas dariam início à "Congregação Congregacional Vale da Bênção". Não tardou para que a pequena comunidade fosse inserida num processo de institucionalização. No fluxo da Renovação Espiritual, a "Congregação Vale da Bênção" recebeu os pastores congregacionais renovacionistas Jônatas Ferreira Catão e Raul de Souza Costa, que estavam arregimentando outros pastores e igrejas para criação da nova denominação congregacional renovada.

Assim, dias após a fundação da Aliança Congregacional, era inaugurada e emancipada a Igreja Evangélica Congregacional Caruaruense, em 19 de agosto de 1967. Os congregacionais renovacionistas de Caruaru, agora, contavam com 
os subsídios eclesiásticos, institucionais e teológicos que dariam legitimidade à novel igreja. No ano seguinte, seu primeiro pastor titular foi eleito, o reverendo José Quaresma de Mendonça. Logo após, a expressão 'vale da bênção' foi retomada, desde então, se reconheceu oficialmente a Igreja Evangélica Congregacional Vale da Bênção. A comunidade composta por aproximadamente setenta membros, entrou numa fase de crescimento e expansão a partir da década de 1980.

No ano de 1986, o reverendo Nicácio Correia de Moura Filho foi empossado pastor titular da $1^{\text {a }}$ Igreja Evangélica Congregacional Vale da Bênção de Caruaru - ou, simplesmente, Vale Central. Notadamente, as atividades evangelísticas desta comunidade foram reforçadas, evidenciada pela abertura de novas congregações, pontos de pregação e, ainda, emancipação de congregações. Com a criação do Departamento de Atividades Missionárias (DEPAM), a Igreja Vale da Bênção Central contribuiu para implantação de igrejas congregacionais filiadas à Aliança Congregacional no agreste e sertão pernambucano, na região metropolitana do Recife, nos estados da Bahia, Paraíba e São Paulo (Siqueira, 2007). Sem desconsiderar a singularidade e relevância do congregacionalismo por si, a roupagem pentecostalizada e adoção de estratégias evangelísticas semelhantes aos pentecostais, indubitavelmente, contribuiu para que os congregacionais renovados crescessem numericamente e expandissem seus territórios de atuação. Atualmente, contando com cerca de quatro mil membros, distribuídos por sete igrejas e quinze congregações somente no municipio de Caruaru.

\section{Considerações finais}

Ao longo deste trabalho, buscamos refletir sobre o Movimento de Renovação Espiritual como importante componente da trajetória histórica do protestantismo e congregacionalismo no país. No entanto, permanece desconhecido por muitos pesquisadores, pouco explorado por uns e desconsiderado por outros tantos. Essa renovação religiosa, com tons e formas pentecostalizadas, parece-nos fundamental para que possamos entender determinados aspectos do campo evangélico e facetas do protestantismo brasileiro contemporâneo. Não obstante, faz-nos ponderar sobre as relações e tensões envolvendo protestantes e pentecostais. 
Tivemos por objetivo, ainda, resgatar a historicidade do congregacionalismo como segmento importante na composição do campo protestante brasileiro, porém, ainda marginalizado no âmbito acadêmico e desconhecido para muitos evangélicos. Ao tratar da Aliança Congregacional e da Igreja Vale da Bênção, procuramos oferecer ao leitor um retrato do Movimento de Renovação Espiritual, seu fenômeno adjacente e suas dobras nos níveis denominacional e comunitário. Destacando que o fenômeno pentecostalizante provocou conflitos e tensões que culminaram na criação de uma nova organização denominacional e comunidades congregacionais renovadas, nas quais o paradigma pentecostal se alinhou com a tradição congregacionalista, dando contornos à cultura e identidade congregacional carismática. Nestes termos, ancoramos a relevância de nosso estudo, esperando contribuir para compreensão socioantropológica, histórica e, quem sabe, teológica do campo evangélico, protestante e congregacional e suas interfaces com o pentecostalismo.

\section{Referências bibliográficas}

ARAÚJO, Rosivaldo de. Ninguém detém! É obra santa. João Pessoa: Ed. Betel Brasileiro, 2013.

BOURDIEU, Pierre. A economia das trocas simbólicas.São Paulo: Ed. Perspectiva, 2007.

CAMPOS, Leonildo Silveira; GUTIÉRREZ, Benjamín F. (Ed.). Na força do Espírito: Os pentecostais na América Latina. São Paulo: ALPR, 1996.

CAMPOS JÚNIOR, Luís de Castro. Pentecostalismo e transformações na sociedade brasileira: A Igreja Avivamento Bíblico. São Paulo: Annablume, 2009.

CÉSAR, Salustiano Pereira. O congregacionalismo no Brasil. Rio de Janeiro: OMEB, 1983.

EVERY-CLAYTON, Joyce Elizabeth Winifred; ARAÚJO, Marcos Robson Quaresma de. Caruaru, cem anos de luz: Primeira Igreja Evangélica Congregacional de Caruaru (1989-1998). Caruaru: Art’Berg Gráfica e Editora, 1998.

MENDONÇA, Antônio Gouvêa. A experiência religiosa e a institucionalização da religião. In: Revista Estudos Avançados, ano XVIII, n 52, ago. 2004, pp. 29-46.

MENDONÇA, Iraci Silva de. Memorial José Quaresma: 50 anos de ministério. Campina Grande: Artexpress Editora, 2007.

MORANTE, Bernardo Luis Campos. El principio pentecostalidad: la unidad en el Espiritu, fundamento de la paz. Salem (EUA): Kerigma Publicaciones, 2016. 
MOREIRA, Thiago. Da tradição à renovação na Igreja Batista da Lagoinha: um olhar sobre o protestantismo renovado. Dissertação (Mestrado em Ciência da Religião), UFJF, Juiz de Fora, 2016.

PEREIRA, Reinaldo Arruda. Igreja Batista da Lagoinha: trajetória e identidade de uma corporação religiosa em processo de pentecostalização. Tese (Doutorado em Ciências da Religião) UMESP, São Bernardo do Campo, 2011.

PORTO FILHO, Manoel da Silveira. Congregacionalismo brasileiro. Rio de Janeiro: DERP-UIECB, 1997.

RODRIGUES, Isaac Martins. História da Assembleia de Deus em Pernambuco.Recife: [s.n.], 1968.

ROLIM, Francisco Cartaxo. Pentecostais no Brasil: uma interpretação sócioreligiosa. Petrópolis: Vozes, 1985.

SANTANA FILHO, Manoel Bernardino. Um pequeno relato das relações entre a Aliança e a União das Igrejas Evangélicas e Congregacionais do Brasil. [S.1.], 2011.

SANTOS, Geraldo Batista dos. Sesquicentenário do congregacionalismo brasileiro (1855-2005). João Pessoa: JRC Editora, 2006.

SANTOS, Valter Borges dos. Origem e institucionalização da Igreja Metodista Wesleyana. Dissertação (Mestrado em Ciências da Religião) UMESP, São Bernardo do Campo, 2014.

SILVA, Gustavo Henrique. Uma Princesa Centenária: Desejos, expectativas e exclusões nas comemorações dos 100 anos de Caruaru-PE (1957). Dissertação (Mestrado em História) UFCG, Campina Grande, 2014.

SIQUEIRA, Daniel Tenório. Igreja Evangélica Congregacional Vale da Bênção: 40 anos de história. Monografia (Bacharelado Livre em Teologia) STCN, Caruaru, 2007.

SOUZA, Carlos Henrique Pereira de. Entre a capela e a catedral: tensões e reinvenções da identidade religiosa na experiência do protestantismo histórico atual. Dissertação (Mestrado em Ciências Sociais) UERJ, Rio de Janeiro, 2013.

TOGNINI, Enéas. Batismo no Espirito Santo. São Paulo: Edições Enéas Tognini, 1986.

\footnotetext{
1 O Movimento Pentecostal ou, simplesmente, pentecostalismo despontou no cenário estadunidense no início do século XX. Esse segmento protestante conjugou uma postura conservadora e, em certo sentido, literalista de interpretação bíblica; um ideário conversionista; uma compreensão escatológica pré-milenista; com crenças e práticas referentes ao ensinamento do batismo com Espírito Santo e da atualidade dos dons carismáticos registrados no Novo Testamento.

${ }^{2}$ Fazemos uso da expressão protestantismo e correlatos - e.g. protestantes históricos como tem sido usualmente aplicada na literatura acadêmica, designandoo conjunto de igrejas vinculadas teológica e historicamente com confissões protestantes originárias das reformas religiosas e/ou do período pós-reforma, dos séculos XVI e XVII.
} 
3 O Movimento de Renovação Espiritual, assim como o pentecostalismo, deu ênfase aos temas da missão evangélica, batismo do Espírito Santo e dons carismáticos e, ainda, ao retorno de Cristo. Cumpre frisar que o fenômeno da pentecostalização não incide na simples assimilação de crenças pentecostais, inclui também um resgate de ênfases doutrinárias que estiveram presentes em segmentos do protestantismo em outros momentos, especialmente, no Grandes Despertamentos ou Reavivamentos, ocorridos na Inglaterra e nos Estados Unidos, entre os séculos XVII e XIX.

${ }^{4}$ Entende-se por protestantismo de missão o conjunto de denominações implantadas no Brasil, em fins do século XIX, por meio de missionários europeus e estadunidenses. Com destaque para os batistas, congregacionais, metodistas e presbiterianos.

5União das Igrejas Evangélicas Congregacionais do Brasil, denominação que surgiu do movimento de restauração denominacional, composta majoritariamente por igrejas do Nordeste.

${ }^{6}$ Entrevista de Anacleto Inácio, pastor congregacional e professor de História do Congregacionalismo, concedida em 02 de junho de 2020.

${ }^{7}$ Entrevista de Josué Eusébio Ferreira concedida em 25 de maio de 2020.

8 Entrevista concedida ao autor em 02 de junho de 2020.

9 Essa informação extraída de Rosivaldo de Araújo (2013, p. 73-77) entra em contradição com a narrativa histórica oficial da Igreja Evangélica Congregacional Vale da Bênção e registrada por Daniel T. Siqueira (2007, p. 14) que afirmam: "Foi durante este periodo que aconteceu o $3^{\circ}$ Encontro de Renovação Espiritual, realizado na cidade de Feira de Santana-BA, no dia 21 de julho de 1967, promovido pelo pastor Rosivaldo de Araújo. O presbítero Caetano Antônio da Silva organizou um grupo e foi ao encontro". Prevendo os esforços e tempo que seriam despendidos para solucionar essa incompatibilidade, preferimos nos limitar a sublinhar essa questão com esta nota.

10 Segundo Araújo (2013), a escolha dessa temática foi baseada no texto bíblico de $2^{\circ}$ Livro das Crônicas, capítulo 20, que relata a intervenção divina para vitória dos judeus numa batalha épica. Celebrando vitoriosos, chamaram o vale onde estavam de Beraca, que traduzido do hebraico significa "bênção".

Recebido em 21/07/2021

Aceito para publicação em 19/08/2021 


\title{
Circuitos evangélicos do Nordeste: contexto geral e caso potiguar
}

\author{
Evangelical circuits in Brazilian Northeast region: \\ general context and the Potiguar case
}

\author{
Waldney de Souza Rodrigues Costa* \\ https://doi.org/10.29327/256659.12.2-7
}

\section{Resumo:}

Embora a Região Nordeste seja conhecida como a mais católica do Brasil, possui um gran-de contingente de evangélicos, especialmente nos centros urbanos do litoral. Esse artigo é escrito com o intuito de contextualizar essa presença evangélica no Nordeste, demonstrando a plausibilidade de que aquilo que ocorre em Natal-RN também esteja ocorrendo em outras cidades da região. Para isso, inicialmente serão analisados os dados do Censo do IBGE realizado em 2010, com foco na dinâmica da urbanização do Nordeste. Depois, será apresentado o circuito evangélico como um recurso teórico que possa ajudar na interpretação dos dados. Por fim, o recurso será aplicado à capital do Rio Grande do Norte, mapeando o seu circuito a partir dos resultados de pesquisas qualitativas. Como será possivel perceber, o circuito da capital potiguar é um caso que pode ilustrar um pouco da dinâmica que ocorre Nordeste afora, assim como em outros centros urbanos do Brasil. Uma dinâmica em que, embora as igrejas permaneçam importantes, as referências da fé evangélica estão espalhadas por vários eixos que estão para além delas e acabam conformando um espaço de circulação de adeptos, curiosos e simpatizantes em meio às próprias referências.

Palavras-chave: Protestantismo e pentecostalismo. Nordeste brasileiro. Religião e urbanização. Rio Grande do Norte.

\section{Abstract:}

Although the Brazilian Northeast Region is known as the most Catholic in Brazil, it has a large contingent of evangelicals, especially in urban centers along the coast. This article is written with the aim of contextualizing this evangelical presence in the Northeast Region, demonstrating that the plausibility of what happens in Natal city (RN) also happens in other cities in the region. For this, some data from the IBGE Census carried out in 2010 are initially analyzed, with a focus on the dynamics of urbanization in the Northeast Region. Afterwards, the evangelical circuit as a theoretical resource that can help in interpreting the data shall be presented. Finally, the resource to Rio Grande do Norte capital city is applied, mapping its circuit based on the results of qualitative researches. As you can see, the circuit of the Potiguar capital city is a case that can illustrate the dynamics that occur throughout the Northeast Region, and in the urban centres of Brazil as a whole. The dynamics in which the references of the evangelical faith are spread over several axes beyond them, although the churches remain important, which end up forming a space for the circulation of adherents, curious people and sympathisers among them.

'Doutor em Ciência da Religião pela Universidade Federal de Juiz de Fora (UFJF). Professor e Chefe do Departamento de Ciências da Religião da Universidade do Estado do Rio Grande do Norte (UERN). E-mail: professordney@gmail.com. 
Keywords: Protestantism and Pentecostalism; Brazilian Northeast region; Religion and urbanization; Rio Grande do Norte (Brazil).

\section{Pontos de partida}

Quando se fala em religião no Nordeste, a primeira imagem que vem à mente é a do catolicismo, especialmente o não oficial, geralmente chamado de popular. Festas, santos não canônicos, benzedeiras, padroeiras... Tudo isso faz parte dessa imagem que não está tão distante da realidade, uma vez que os próprios recenseamentos recentes têm demonstrado que essa região do Brasil possui uma proporção maior de católicos que as demais. No entanto, os mesmos recenseamentos indicam um grande contingente de evangélicos no Nordeste. São quase 9 milhões segundo os dados do Censo de 2010 do IBGE, o que é mais de $20 \%$ do total de evangélicos do país. Como isso ocorre e o que representa para a discussão sobre as religiões no Nordeste?

Esse artigo é escrito com o intuito de contribuir com essa discussão, contextualizando essa presença evangélica no Nordeste em duas frentes: primeiro analisando alguns dados das declarações religiosas deste último recenseamento do IBGE, colocando-as em função de grandes centros urbanos nordestinos; depois fazendo uma descrição mais qualitativa do caso da Região Metropolitana de Natal (RN) para que sirva de indicador do que pode estar ocorrendo nos demais centros e não pode ser visualizado imediatamente na quantificação de autodeclarações.

A aposta é que, ao trabalhar com dados do Nordeste e da região no entorno da capital potiguar, seja possivel visualizar dinâmicas religiosas que estão para além desses lugares, como um exercício exploratório que não pretende encerrar, mas abrir uma discussão sobre o que é ser evangélico, nesse sentido mais abrangente e menos referenciado em igrejas ou denominações específicas. Para isso, na passagem da contextualização do Nordeste à descrição de Natal-RN será introduzida a noção de circuito evangélico como um recurso analítico que permite a visualização da articulação entre o que ocorre nas igrejas e o que ocorre fora delas, especialmente no lazer e no consumo. É ela que tornará mais explícitas as dinâmicas em questão.

\section{Evangélicos no campo religioso brasileiro e a questão do Nordeste}


Um dos fatos mais comentados a respeito do campo religioso brasileiro é o declínio do catolicismo, mas ele não vem sozinho. Dizia Pierre Sanchis (2018) que ele sempre vem acompanhado de uma ampliação da diversidade religiosa. Pondera o autor que muito dessa ampliação pode estar relacionada à mudança recente dos instrumentos de análise das religiões. Porém, não há como negar que existam transformações reais em jogo. O Brasil está passando por uma transição religiosa marcada pela queda da hegemonia católica (ALVES, BARROS, CAVENAGHI, 2012).

É claro que qualquer especialista em catolicismo no Brasil se incomoda com essa redução. Há muito mais coisas acontecendo no mundo católico, uma vez que a perda do número de adeptos é acompanhada por uma diversificação interna. Porém, é essa perda que salta aos olhos quando se trabalha dentro do paradigma de campo religioso. Como explica Bourdieu (2011), quem diz campo, diz campo de forças, forças em oposição. Enquanto uma demonstra menos vigor, outra emerge. Isso cria um procedimento específico de análise das religiões que não explicita tudo a respeito delas, mas aprimora o olhar para aspectos específicos. No caso, os aspectos da concorrência entre elas. Embora muitos utilizem livremente o termo campo, acionando apenas a ideia de microcosmo relativamente autônomo (BOURDIEU, 2004), na origem, ele também carrega essa predileção pela análise da concorrência entre as forças internas e isso também se aplica ao campo religioso.

No caso do Brasil, tornou-se muito comum uma adaptação da proposta inicial de Bourdieu (2007). Se na origem, ao falar de religião, o autor se vale de tipos ideais weberianos, aqui, esses tipos foram substituídos por religiões presentes no território nacional. Ao mapear as forças que se enfrentam no campo religioso, ao invés de tratar da luta entre o mago, o profeta e o sacerdote, como é recorrente nas analises bourdianas (BOURDIEU, 2004, 2011), os brasileiros preferem falar do catolicismo e sua relação com outras religiões que emergem como forças concorrentes. Assim aparecem os evangélicos: uma força que emerge como principal ameaça à hegemonia católica.

Há um porém. Essa constatação adveio de muitos meios, mas principalmente dos últimos recenseamentos. Para mapear o campo religioso brasileiro e as principais forças emergentes, tornou-se comum o uso dos dados dos sucessivos Censos realizados pelo IBGE. Eles deixam muitas lacunas, é verdade, consti- 
tuindo mais como pontos de partida para outras análises do que respostas definitivas para as inquietações a respeito das religiões no Brasil. Contudo, o seu conjunto constitui uma espécie de retrato da nação (MENEZES, 2013). Para reconstituir o filme são necessárias outras pesquisas. Mas isso não muda o fato de que, com esses dados, tem-se uma imagem do que está ocorrendo no país. E em que posição os evangélicos aparecem nessa foto? Em ascensão? Sim, mas com uma maior dificuldade de crescimento na Região Nordeste.

O IBGE vem registrando o crescimento evangélico em sucessivas pesquisas censitárias. O percentual de brasileiros que assim se identificam passou de cerca de 6,6\% no Censo de 1980 para 9,0\% no de 1991 e para 15,5 \% no de 2000 , chegando a $22,2 \%$ no de $2010 .{ }^{1}$ Só que a região Nordeste, aparentemente, não está acompanhando essa direção nacional. Perceba a diferença na tabela abaixo:

Tabela 1: Percentual das declarações religiosas nas Grandes Regiōes do Brasil

\begin{tabular}{|l|c|c|c|c|c|c|}
\hline $\begin{array}{c}\text { Declaração } \\
\text { religiosa }\end{array}$ & Norte & Nordeste & Sudeste & Sul & Centro-Oeste & Brasil \\
\hline Católica & 60,6 & 72,2 & 59,5 & 70,1 & 59,6 & 64,7 \\
\hline Evangélica & 28,5 & 16,4 & 24,6 & 20,2 & 26,8 & 22,2 \\
\hline Espírita & 0,5 & 0,8 & 3 & 2 & 2,3 & 2,0 \\
\hline Afro-Brasileira & 0,1 & 0,2 & 0,4 & 0,6 & 0,1 & 0,3 \\
\hline Sem Religião & 7,8 & 8,3 & 9 & 4,8 & 8,4 & 8 \\
\hline Outra & 2,5 & 2,1 & 3,5 & 2,3 & 2,8 & 2,7 \\
\hline
\end{tabular}

Fonte: Produzido pelo autor a partir dos dados do Censo 2010 do IBGE.

Com essa imagem, a primeira impressão é que o que acontece no Nordeste em matéria de religião estaria destoando daquilo que ocorre no país. E se variarmos as autodeclarações por Estado da Federação, essa diferença pode se tornar ainda maior. Só o Pernambuco parece se aproximar da proporção de população evangélica do país, e, com a Bahia, se aproximar da proporção de católicos. O que será possivel conferir na próxima tabela: 
Tabela 2: Percentual das declarações religiosas na Região Nordeste do Brasil

\begin{tabular}{|l|c|c|c|c|c|c|c|c|c|c|}
\hline $\begin{array}{c}\text { Declaração } \\
\text { religiosa }\end{array}$ & MA & PI & CE & RN & PB & PE & AL & SE & BA & Br \\
\hline Católica & 74,5 & 85,1 & 78,9 & 76 & 77 & 66 & 72,3 & 76,4 & 65,3 & 64,7 \\
\hline Evangélica & 17,2 & 9,7 & 14,6 & 15,4 & 15,2 & 20,3 & 15,9 & 11,8 & 17,4 & 22,2 \\
\hline Espírita & 0,2 & 0,3 & 0,6 & 0,8 & 0,6 & 1,4 & 0,6 & 1,1 & 1,1 & 2,0 \\
\hline Afro-Brasileira & 0,1 & 0,1 & 0,1 & 0,04 & 0,1 & 0,1 & 0,1 & 0,2 & 0,3 & 0,3 \\
\hline Sem Religião & 6,6 & 3,4 & 4,3 & 6,4 & 5,7 & 10,4 & 9,7 & 8,6 & 12 & 8 \\
\hline Outra & 1,4 & 1,4 & 1,5 & 1,9 & 1,4 & 1,8 & 1,4 & 2,3 & 3,9 & 2,8 \\
\hline
\end{tabular}

Fonte: Produzido pelo autor a partir dos dados do Censo 2010 do IBGE.

Será que o Nordeste, de fato, não está acompanhando a transição religiosa do Brasil? A resposta a essa questão não pode ser dada sem levar em conta um dos eixos mais importantes dessa transição: a urbanização. Alves, Barros e Cavenaghi (2012), analisando os dados do Censo de 2010, indicam que os evangélicos levam vantagem sobre os católicos nas regiões mais sujeitas à metropolização. Inclusive relacionam o fato de a Região Metropolitana do Rio de Janeiro estar com a transição religiosa cerca de 30 anos à frente da transição do país com o fato de o Rio de Janeiro ser o Estado mais urbanizado (ALVES, BARROS e CAVENAGHI, 2012). Sendo assim, embora a Região Nordeste como um todo apresente um certo contraste em relação ao Brasil, talvez tenha algo diferente a mostrar em seus centros urbanos. Isso nós podemos conferir. Iniciemos com a análise das declarações nas capitais:

Tabela 3: Percentual das declarações religiosas nas capitais do Nordeste do Brasil

\begin{tabular}{|l|c|c|c|c|c|c|c|c|c|}
\hline $\begin{array}{c}\text { Declaração } \\
\text { religiosa }\end{array}$ & $\begin{array}{c}\text { São } \\
\text { Luis } \\
\text { (MA) }\end{array}$ & $\begin{array}{c}\text { Teresina } \\
\text { (PI) }\end{array}$ & $\begin{array}{c}\text { Fortaleza } \\
\text { (CE) }\end{array}$ & $\begin{array}{c}\text { Natal } \\
\text { (RN) }\end{array}$ & $\begin{array}{c}\text { João } \\
\text { Pessoa } \\
\text { (PB) }\end{array}$ & $\begin{array}{c}\text { Recife } \\
\text { (PE) }\end{array}$ & $\begin{array}{c}\text { Maceió } \\
\text { (AL) }\end{array}$ & $\begin{array}{c}\text { Aracaju } \\
\text { (SE) }\end{array}$ & $\begin{array}{c}\text { Salvador } \\
\text { (BA) }\end{array}$ \\
\hline Católica & 65,9 & 79,0 & 67,9 & 67,4 & 63,3 & 54,3 & 62,0 & 70,9 & 51,6 \\
\hline Evangélica & 23,6 & 13,3 & 21,4 & 20,9 & 24,0 & 25,0 & 23,7 & 15,2 & 19,6 \\
\hline Espírita & 0,6 & 0,9 & 1,3 & 1,8 & 1,8 & 3,6 & 1,4 & 2,7 & 3,2 \\
\hline Afro-Brasileira & 0,1 & 0,2 & 0,2 & 0,1 & 0,2 & 0,2 & 0,1 & 0,4 & 1,0 \\
\hline Sem Religião & 7,7 & 4,5 & 6,7 & 7,9 & 8,2 & 14,6 & 10,5 & 8,3 & 17,6 \\
\hline Outra & 2,1 & 2,1 & 2,5 & 1,9 & 2,5 & 2,3 & 2,3 & 2,5 & 7,0 \\
\hline
\end{tabular}

Fonte: Produzido pelo autor a partir dos dados do Censo 2010 do IBGE.

Como se pode perceber, ao segregarmos os dados das capitais do Nordeste, as proporções se aproximam muito mais das identificadas no quadro geral do país. Quase todas as nove cidades possuem um percentual de evangélicos pró- 
ximo ao percentual nacional (22,2\%). Apenas Teresina, no Piauí (13,3\%) e Aracaju, no Sergipe $(15,2 \%)$ estão a mais de três pontos percentuais de distância para baixo.

Quanto a isso, é preciso levar em conta que:

\begin{abstract}
Apesar do processo de urbanização na região Nordeste ter sido um pouco mais lento em comparação a outras regiões do país, sobretudo frente ao Sudeste, no final do século XX, grandes cidades nordestinas, algumas constituídas como regiões metropolitanas consolidadas, apareceram como espaços de grande concentração populacional e de atividades econômicas mais avançadas (BEZERRA, 2020, p. 396).
\end{abstract}

A concentração populacional sempre foi um fator associado ao crescimento da proporção de evangélicos e as capitais do Nordeste não parecem fugir à regra. Algo que não se aplica apenas a essas cidades. Se expandirmos o escopo de análise para as Regiões Metropolitanas que surgem a partir das capitais ${ }^{2}$, tem-se um quadro que também está muito próximo do brasileiro:

\title{
Gráfico 1: Percentual das declarações religiosas em Regiões Metropolitanas do Nor- deste do Brasil em 2010 3
}

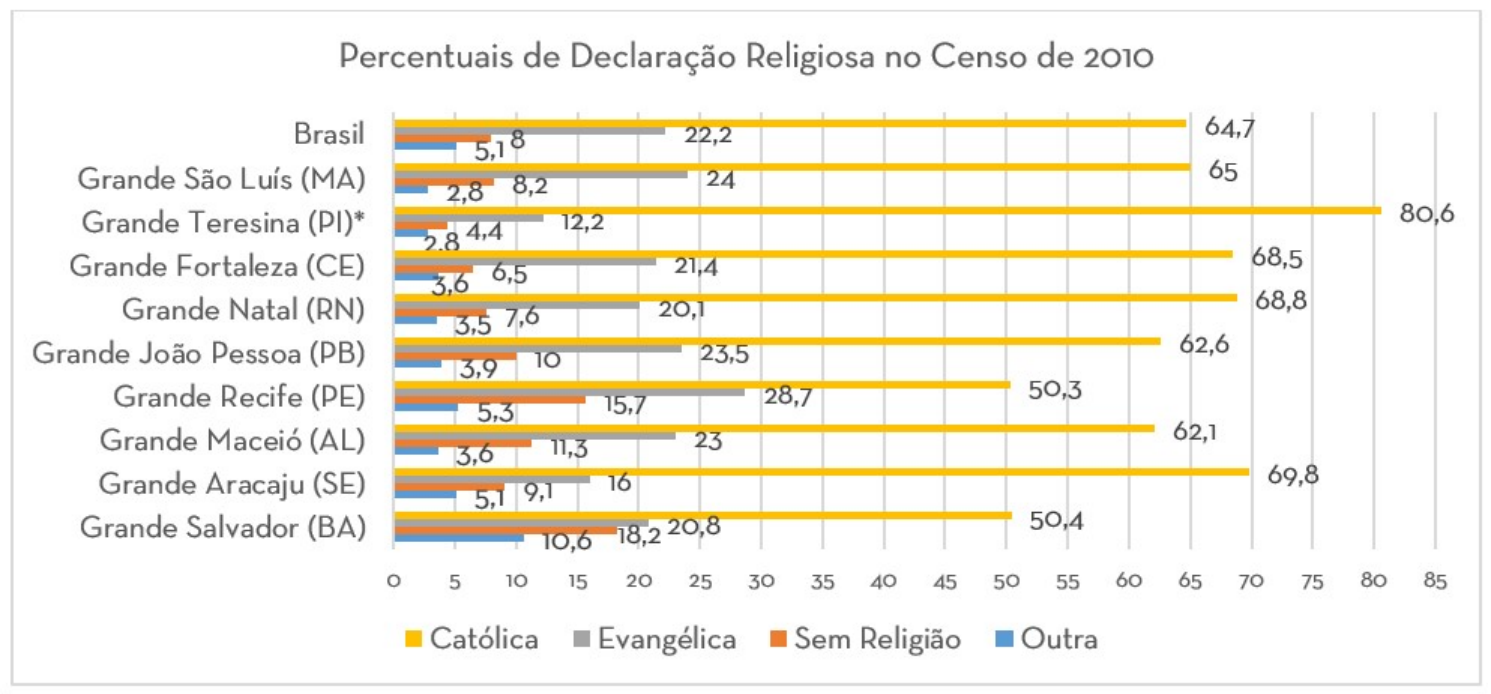

Fonte: Produzido pelo autor a partir dos dados do Censo 2010 do IBGE.

Novamente, com as exceções da Grande Teresina $(12,2 \%)$ e da Grande Aracaju (16\%), a proporção de evangélicos na população apresenta-se próxima ou acima da proporção do país. Para se ter uma ideia do grau de proximidade, vide 
abaixo um gráfico gerado com a junção dos dados do gráfico anterior, seguido de um gráfico do Brasil:

\section{Gráfico 2:Percentual das declarações religiosas em Regiões Metropolitanas das capitais do Nordeste do Brasil em 2010}

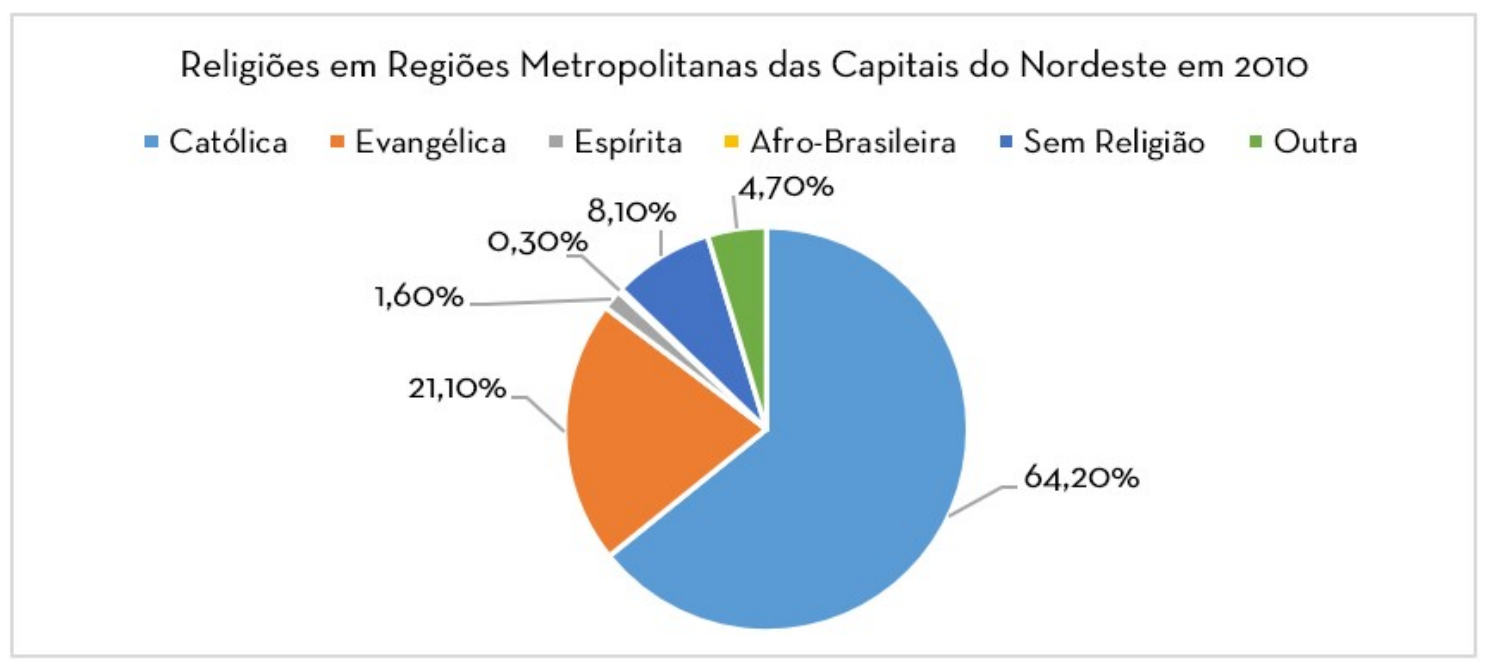

Fonte: Produzida pelo autor a partir de dados do Censo 2010 do IBGE.

Gráfico 3:Percentual das declarações religiosas no Brasil em 2010

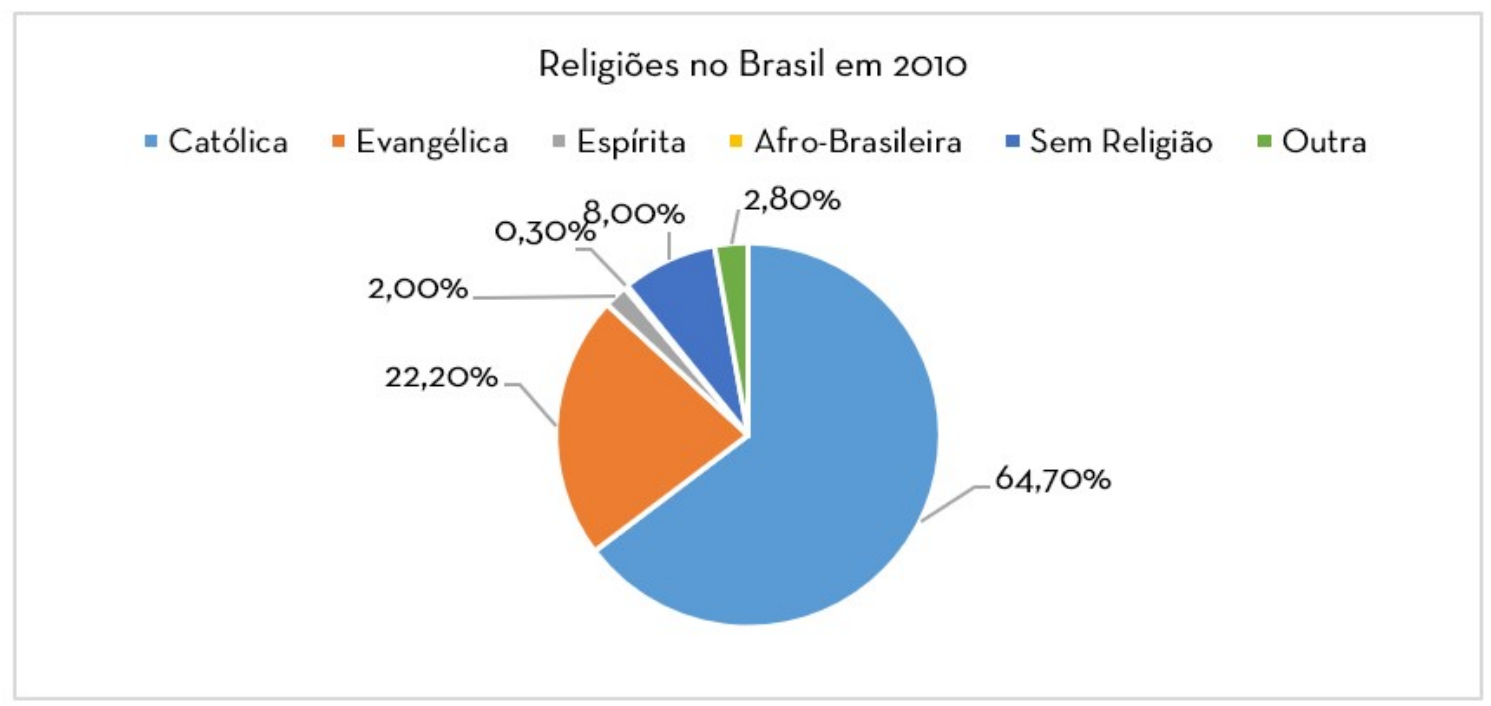

Fonte: Produzida pelo autor a partir de dados do Censo 2010 do IBGE.

Com esse procedimento, tem-se, no conjunto das Regiões Metropolitanas que surgem a partir das capitais do Nordeste, uma imagem das declarações religiosas que se aproxima da imagem do Brasil. É um indicativo de que, embora essa região possua especificidades, não é correto afirmar que ela não esteja a- 
companhando a transição religiosa do país. No caso nordestino, essa transição é mais experimentada ao litoral, onde se encontram os centros administrativos, caracterizados pela maior metropolização. Nesse contexto, importa saber como essa urbanização favorece o crescimento evangélico. A descrição do caso da Região Metropolitana de Natal-RN pode contribuir nessa direção. Porém, nesse artigo, ela dependerá da compreensão de um recurso analítico específico que foi desenvolvido em meio a uma pesquisa etnográfica anterior e será apresentado a seguir.

\section{O circuito evangélico como recurso analítico}

"O crente não vai só da casa pra igreja e da igreja pra casa. Tem muito mais coisas que crente faz!". Se não entender essa dinâmica fica dificil compreender o que é ser evangélico em Natal (RN) ou em qualquer lugar. Isso vale para quase todo o Brasil. É claro que em áreas mais afastadas dos centros urbanos há grupos mais isolados, um pouco mais restritos a uma igreja. Mas até nesses lugares, quando chega a internet, evangélicos de lá entram em contato com outros de fora e nessa interação passam a fazer parte de uma realidade mais ampla. Nela, a igreja é uma das referências de fé. Não a única. Para alguns, nem a mais importante.

Foi para facilitar o entendimento dessa dinâmica que criei o conceito de circuito evangélico, inspirado nos trabalhos em antropologia urbana desenvolvidos por Magnani (2012). A fim de tornar o texto mais fluido e não muito extenso, não farei a exposição do passo a passo da etnografia que levou a isso. Ele pode ser consultado em Costa (2019). Em termos bem gerais, consistiu em duas etapas, realizadas entre 2013 e 2018; uma seguindo um grupo de evangélicos por diferentes espaços em que se encontram, outra seguindo canções por diferentes espaços em que são utilizadas por evangélicos. A frase com a qual abri essa seção me foi dita por uma jovem com quem interagi na primeira etapa. Parte da observação participante foi realizada em Natal (RN) e servirá de base para a descrição a seguir. Quando não for o caso, serão indicadas as pesquisas complementares. Mas o ponto central é que, adotando esse procedimento, deparei-me com uma dinâmica que integrava evangélicos de diferentes denominações, ou seja, de diferentes "famílias de igrejas", como dizia Antônio Gouvêa Mendonça (1995) ao se referir aos conglomerados batistas, metodistas, presbiterianos, entre outros. O conceito de circuito evangélico diz respeito à ampla circulação que ocorre entre as pessoas que participam deles. E não apenas entre elas. Essa circu- 
lação acaba envolvendo também quem tem alguma curiosidade ou simpatia por algo desse universo religioso, ainda que não tenha se convertido e não seja membro de nenhuma igreja.

Mas o que é que circula? Primeiramente, as próprias pessoas. Houve um tempo em que cada crente ficava mais restrito ao ambiente da sua igreja ou de uma denominação. Isso é cada vez mais raro. Tanto que criou um problema para a análise do campo religioso brasileiro. Durante muito tempo, buscou-se separar protestantes e pentecostais nas interpretações, mas a grande quantidade de respostas genéricas complicou bastante essa distinção. Mariz e Gracino Júnior (2013) explicam que, quando o agente censitário pergunta Qual a sua religião ou culto? pode ser que a pessoa não entenda imediatamente que se espera que ela responda a igreja de que faz parte ou, mesmo entendendo, não julgue necessário. Daí o contingente de 9,2 milhões de declarações religiosas que acabaram categorizadas como evangélica não determinada. Podem ser pentecostais, não pentecostais ou até pessoas sem vínculo institucional. Não dá para saber ao certo. Até porque, pelo que observei em minha pesquisa de campo (realizada em Natal-RN, mas não só), na prática, o que nenhum crente tem deixado de fazer é visitar. Até consideram importante ter uma congregação de referência principal, onde se ocupa algum cargo ou se exerce algum trabalho mais frequente, mas ir a um culto ou dois da igreja de um amigo crente de outra denominação tornou-se muito comum. Isso sem contar os eventos que, organizados por igrejas maiores, empresas ou alguma ONG, acabam atraindo pessoas que frequentam igrejas evangélicas dos mais variados tipos. Foi neles que realizei boa parte da minha observação participante.

Pessoas circulam e, com elas, uma série de coisas. E nesse ponto é preciso usar a ideia de coisa mesmo, pois a variedade é grande. Vai de Bíblia a bijuteria, de gravações de pregações a cadernos com mensagens do Smilinguido, de livros a vídeos no YouTube. Uma extensa cultura material em movimento. Crentes, no exercício de sua fé, criam coisas, e elas circulam bastante. Mais que as próprias pessoas. A parte mais visível dessa circulação pode até ser pensada como uma espécie de cultura pública, como descreve Giumbelli (2014).

Circulam pessoas, circulam coisas e circulam em diferentes espaços. Físicos ou virtuais, locais ou globais. Há circulação em uma pequena comunidade na periferia, mas também nas amplas redes internacionais. Neste exato momento, a música gospel que uma mãe canta baixinho em um bairro da periferia tentando 
fazer sua filha dormir pode ser a mesma tocada pela banda de alguma igreja no Japão, ou no carro de algum jogador de futebol que, na Europa, escuta com saudades de sua família no Brasil. É claro que nem tudo e nem todas as pessoas circulam com toda essa extensão, mas o movimento é tal que seu mapeamento escapa a qualquer crente ou pastor.

Sendo assim, um circuito evangélico é algo que surge em paralelo às igrejas, embora se mantenha em relação com elas. Como o dilema do ovo e da galinha, é dificil dizer qual nasce primeiro. Faz sentido pensar que as igrejas surgem antes, mas o trânsito pelo circuito pode inspirar pessoas a criarem novas igrejas, daí a dificuldade. Em todo caso, para a sua melhor compreensão, é melhor tratar os termos protestantismo de imigração, protestantismo de missão, pentecostalismo e neopentecostalismo, tão presentes na literatura, como formas de qualificar igrejas e/ou denominações, não o circuito. Sempre quando esses termos são discutidos, é comum a indicação de denominações de referência para a categoria, como a Luterana para o protestantismo de imigração, a Metodista para o protestantismo de missão, a Assembleia de Deus para o pentecostalismo e a Igreja Universal do Reino de Deus para o neopentecostalismo ${ }^{4}$. Isso pode ser conferido nos textos clássicos de Mendonça (1995) e Mariano (1999), mas é uma constante na literatura. Essa é uma espécie de estrutura de base a partir da qual os evangélicos se movimentam. Só que existe uma realidade que emergiu a partir dessa base e se mantém paralela a ela. Mafra (2001) deu um passo importante ao abrigar toda a discussão na categoria comum de evangélico e essa parece ser a melhor forma de qualificar uma realidade que afeta todas as denominações, pentecostais ou não, sem pertencer a nenhuma.

Parafraseando Malinowski (2016), poderiamos dizer que a estrutura de base, formada pelas diferentes denominações, é o esqueleto dessa fé. É preciso desvendar a carne e o sangue para que se compreenda a sua vitalidade. Quanto à primeira, podemos falar da disposição dos corpos nos espaços. O processo de urbanização faz com que os diferentes entrem em contato. A maior quantidade de pessoas presentes em um mesmo espaço compartilhado abre caminhos para mudanças, inclusive de religião. Mas também permite que semelhantes se encontrem e se vejam como tal. Uma igreja minoritária, quando percebida como próxima a outras, passa a constituir um grupo que talvez já não seja tão minoritário. Assim é com os evangélicos. 
Mas essa nova percepção só é possivel se traduzida em termos que aglutinem as pessoas de diferentes igrejas. Foi assim que crente se tornou uma forma de se referir às pessoas que têm ligação com alguma igreja categorizada nos termos citados anteriormente. Só que ela é mais usada entre os próprios envolvidos,

sobretudo quando querem fazer algum gracejo entre si. Quando interagem com quem não é crente, preferem o termo evangélico ou cristão. O problema é que cristão aqui no Brasil sempre carece de clareza por conta da forte presença católica. Assim, o termo evangélico acabou se tornando o mais comum. E ele ainda divide espaço com o gospel, que é muito utilizado para qualificar coisas que possam ser comercializadas, como músicas, shows, programas de TV, revistas, entre outras. Mas o mais importante é que, no fim das contas, o avanço da urbanização no Brasil traz consigo a popularidade dos termos crente, evangélico e gospel nas regiões metropolitanas. E esses termos só fazem algum sentido porque existe um sangue circulando entre essa carne. A ideia de circuito é útil para a sua descrição.

É a partir dessa chave interpretativa que se pode entender a presença evangélica em centros urbanos do Nordeste. Ela é volátil o suficiente para ser adaptada a diferentes cenários, podendo ser reduzida a um bairro, um conjunto de ruas, ou expandida para um Estado, uma Região, o Brasil... A seguir, Natal (RN) se tornará uma espécie de laboratório, onde o conceito de circuito evangélico é testado como instrumento de identificação de dinâmicas locais.

\section{Caso potiguar: o circuito evangélico de Natal - RN}

Vimos na contextualização inicial que a urbanização tem alterado o perfil social da população brasileira e nordestina, e a transição religiosa faz parte dessa alteração. Isso é algo que pode ser visualizado Rio Grande do Norte, especialmente nas diferenças entre as suas mesorregiões: 


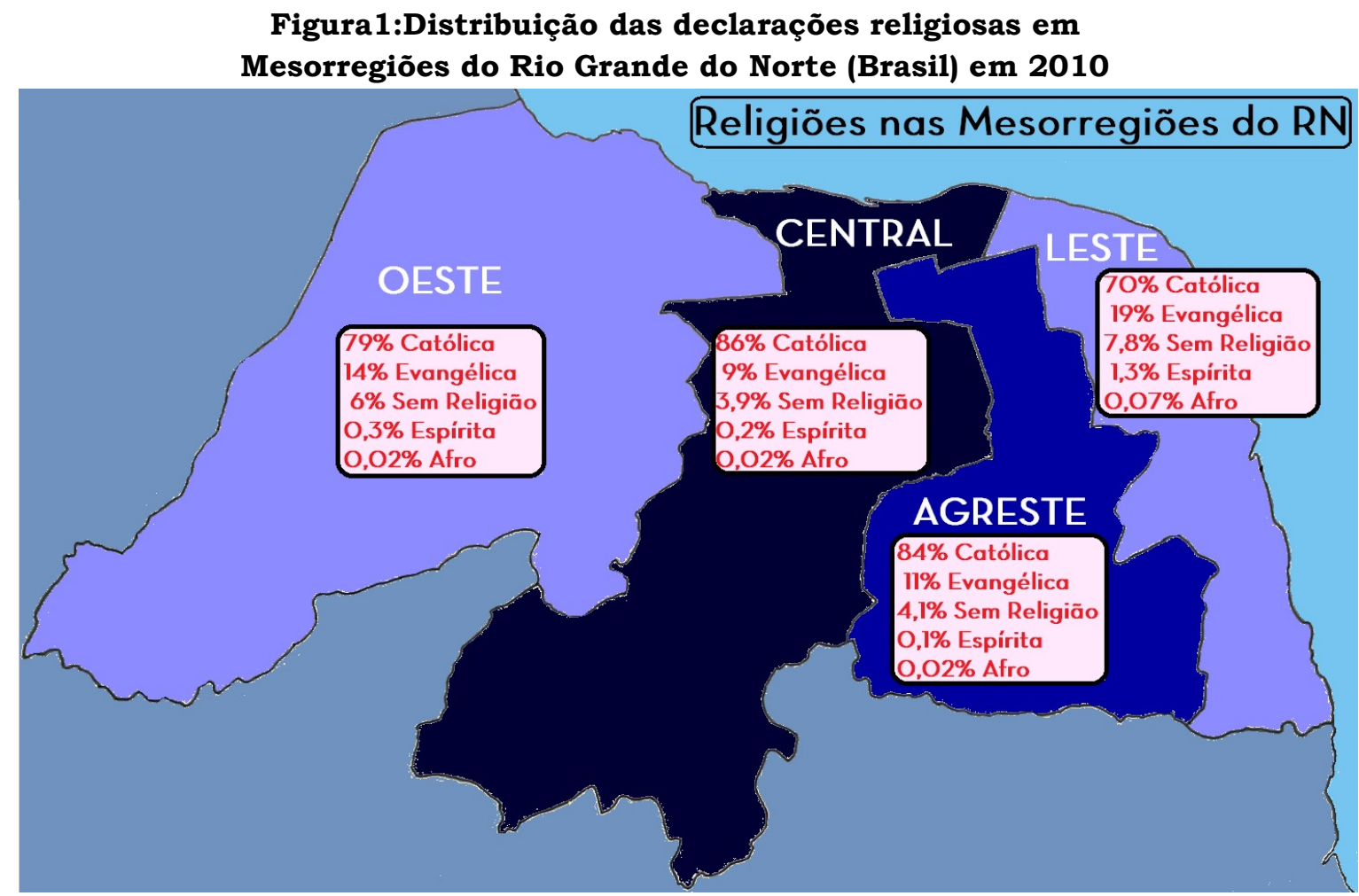

Fonte: Produzida pelo autor a partir de dados do Censo 2010 do IBGE.

É visivel na imagem acima que, no Rio Grande do Norte, o catolicismo parece ter medo de água. Quanto mais perto do litoral, menor a proporção de católicos de uma mesorregião. Mas isso nada tem a ver com a água. O que está em jogo é a urbanização que, via de regra, é mais intensa no litoral, já que boa parte do desenvolvimento começou por lá. A Mesorregião Oeste destoa da regra exatamente por conta de Mossoró que, embora tenha uma localização diferente, participa do processo como integrante de uma rede urbana interiorizada (BEZERRA, 2020).

Conhecida como a "noiva do sol", a capital do Rio Grande do Norte ainda possui alguns acentos em relação ao restante do Estado. Sua Região Metropolitana, na atual configuração, é a quarta maior aglomeração urbana do nordeste brasileiro, constituída por Natal e outros treze municípios (Arês, Ceará Mirim, Extremoz, Goianinha, Ielmo Marinho, Macaíba, Maxaranguape, Monte Alegre, 
Nísia Floresta Parnamirim, São Gonçalo do Amarante, São José do Mipibu e Vera Cruz). Essa diferença quanto à urbanização é acompanhada de uma variação na distribuição das declarações religiosas:

Tabela 6: Percentual das declarações religiosas em 2010 - Comparação RN/Brasil

\begin{tabular}{|l|c|c|c|c|c|}
\hline $\begin{array}{c}\text { Declaração } \\
\text { religiosa }\end{array}$ & Natal & $\begin{array}{c}\text { Região Metropolita- } \\
\text { na de Natal }\end{array}$ & $\begin{array}{c}\text { Rio Grande } \\
\text { do Norte }\end{array}$ & Nordeste & Brasil \\
\hline Católica & 67 & 69 & 76 & 72 & 65 \\
\hline Evangélica & 21 & 20,5 & 15 & 16 & 22 \\
\hline Espírita & 1,8 & 1,5 & 0,7 & 0,8 & 2,0 \\
\hline Afro-brasileira & 0,08 & 0,09 & 0,04 & 0,16 & 0,3 \\
\hline Sem Religião & 7,9 & 7,6 & 6,4 & 8,3 & 8 \\
\hline Outra & 2,2 & 1,3 & 1,9 & 2,7 & 2,7 \\
\hline
\end{tabular}

Fonte: Produzido pelo autor a partir dos dados do Censo 2010 do IBGE.

Como é possivel perceber na tabela acima, o perfil de Natal e de sua Região Metropolitana é mais semelhante ao do Brasil do que ao do Nordeste ou do próprio RN. Chama a atenção a maior presença evangélica ${ }^{5}$. Natal (RN) experimentou, em meio à sua urbanização, tanto o surgimento de diferentes igrejas evangélicas, quanto a popularidade dos termos crente, gospel e evangélico. Já vimos que são coisas que ocorrem em paralelo e podem se retroalimentar. A questão agora é descrever como isso ocorre nessa região.

Já foi dito no tópico anterior que a circulação aqui em jogo se dá entre pessoas e coisas. Ela se torna mais evidente em lugares que se tornam eixos de encontro e passagem e a descrição será focada neles. Podem existir outros, mas destacarei alguns mais evidentes. A perspectiva é a mesma de Meredith McGuire (2008) que considera que, para entender uma religião, não basta estudar os pacotes estruturados pelas instituições religiosas, é preciso levar em conta como as pessoas vivem a sua fé no dia a dia de suas vidas. Isso é muito importante no caso evangélico, pois, muitas vezes, a própria residência de cada crente torna-se um espaço de circulação de expressões de fé. Primeiro, por que as próprias igrejas costumam estimular reuniões caseiras, embora deem nomes diferentes para isso. "Células", "grupo caseiro", "reunião no lar", "culto em casa", o nome pouco importa. O fato é que muitos crentes abrem as salas e cozinhas de suas casas para reuniões com intuito religioso. Há até a intenção de chamar aquele vizinho não crente para participar: quem sabe ele não se converte? Porém, tornou-se ha- 
bitual convidar também, amigos crentes, membros de outras igrejas. Participar do culto na casa de um amigo é uma corriqueira expressão de camaradagem. Uma forma de aproximar colegas de trabalho, de escola, de faculdade, do curso de inglês, etc.

Encontros desse tipo permitem trocas religiosas, com certeza, mas o mais importante nem é a reunião em si, mas o que ocorre depois dela. Quando o culto acaba e tem-se algum lanche ou coisa do tipo, sempre há conversa e, com ela, troca de ideias. E também pode ocorrer algum empréstimo de livro, CD, DVD, Bíblia, etc. Ou o compartilhamento de algum arquivo digital, com conteúdos do tipo. Tem gente que já vai para a reunião com um pendrive no bolso. Se você mora em Natal (RN) e uma vez por semana escuta algum barulho de conversas e cantos aí na casa de algum vizinho ou na sala de reuniões do condomínio, saiba que há uma dinâmica religiosa operando ali. Assim, um espaço aparentemente privado torna-se um eixo de circulação.

É o que também acontece com os automóveis. Como descreve Roberto DaMatta (2012), no Brasil, de modo geral, quando entram no espaço familiar, os carros deixam de ser objetos pessoais e são dotados de afeto. Se mais antigo costuma até ganhar algum apelido. Como uma espécie de extensão da casa na via pública, muitos gostam de dar ao automóvel algum marcador familiar. No caso evangélico, eu acrescentaria que pode ser uma Bíblia no painel, alguns cartões do Smilinguido no porta luvas, um adesivo na traseira com algum símbolo ou versículo bíblico. Há até os mais ousados colocam frases inteiras, tais como "foi Deus que me deu”, em tamanhos bem chamativos. É só reparar nos carros parados no sinal de qualquer Avenida em Natal (RN) que sempre dá para identificar algum desse tipo. E, em automóveis, quando um crente dá carona para seu amigo de outra igreja, surge outro espaço de troca. É claro que ela não precisa necessariamente ter a ver com religião, mas é comum que os crentes troquem, nem que sejam só ideias, sobre suas experiências de fé. É outro eixo de circulação, embora também um pouco mais privado.

O circuito evangélico começa a ficar mais visível ao público através dos espaços urbanos que são apropriados para oração comum. Conhecidos entre crentes como os "montes", eles acabam se tornando lugares de peregrinação. Trata-se de algum espaço mais deserto e de acesso mais dificil, geralmente em algum ponto alto da cidade, onde evangélicos costumam se reunir para orar de 
forma mais reservada, porém pública e aberta à presença de membros de diferentes igrejas. Ir a lugares desse tipo é mais comum entre pentecostais, mas o clima de reserva e segredo aguça a curiosidade de muitos não pentecostais. Toda cidade com certa proporção de evangélicos tem algum espaço assim. Em Natal (RN) tem-se notícia de um em Pitimbu, no prolongamento da Av. Prudente de Morais. Havia outros, mas situações de violência fizeram com que a peregrinação parasse. É o caso do espaço que havia em Felipe Camarão e de um outro nas dunas de Genipabu. Casos de assalto, assassinato e até estupro de pessoas que subiam para orar desencorajam novos grupos ${ }^{6}$. A Polícia Militar considera que esse hábito acaba colocando os fiéis em risco. Mas pode ser que tenham surgido outros espaços do tipo, divulgados só entre evangélicos mesmo.

Essa troca entre crentes diferentes faz com que muito do que acontece pela cidade seja de conhecimento corrente entre eles. Quem é mais frequente em uma igreja, depois de certo tempo de interação, passa a saber de muito do que ocorre em outras igrejas, as vezes bem diferentes da sua. Aliás, quanto mais diferente uma igreja, mais ela chama a atenção. Algumas se tornam, elas mesmas, centros de visitação de evangélicos, que vão ao seu culto nem que seja só uma vez para matar a curiosidade. A igreja Videira, em Igapó, na Zona Norte de Natal (RN), é um pouco assim. Muitos crentes, sobretudo jovens, ficam curiosos em saber como é o culto com as luzes apagadas e refletores coloridos. Na verdade, nem todo culto dessa igreja é assim, mas esse é o imaginário que se tem sobre ela. Coisas extraordinárias que surgem em uma igreja podem torná-la um eixo de circulação de evangélicos em geral.

Eventos são muito propícios para criar situações extraordinárias de peregrinação. Um show gospel do Fernandinho na Igreja Assembleia de Deus Bom Refúgio que fica próxima ao Midway, por exemplo, desencadeia uma série de fluxos evangélicos pela cidade. Membros de igrejas menores, que não teriam condição de promover algo do tipo, se deslocam em peso, o que gera até caravanas vindas de outros municípios. Ainda que essa igreja seja mais comum, no dia do evento ela não é. E cabe acrescentar que não só as igrejas promovem eventos evangélicos. Ao criar situações extraordinárias, diferentes organizações não eclesiásticas tornam-se eixos do circuito. Seja empresa privada, como a que promoveu um show da Gabriela Rocha no Teatro Riachuelo; ou ONGs, como a Associação Para a Promoção do Bem, que promoveu a Expo Cristã Parnamirim (RN) em um parque na Região Metropolitana de Natal; ou até mesmo instituições públi- 
cas, como a própria Prefeitura do Natal quando apoia, por exemplo, a Marcha para Jesus - evento evangélico que faz parte do calendário oficial de Natal (RN).

Em meio às organizações não eclesiásticas, há um tipo de empresa que merece destaque: as lojas de artigos evangélicos. Volta e meia elas estão envolvidas nos eventos, seja na promoção, na venda de ingressos, no apoio à divulgação, na montagem de barracas nas entradas dos shows. Só que essas lojas ultrapassam o escopo dos eventos. Elas mesmas são frequentadas por crentes de diferentes igrejas em busca de Bíblias, revistas de escola dominical, livros, camisetas, bijuterias, DVDs, CDs, entre outros. É nelas em que são adquiridas muitas coisas compartilhadas nos cultos caseiros e nas caronas. Qualquer pessoa pode reconhecê-las se estiver atenta ao andar pelos centros comerciais de Natal $(\mathrm{RN})$. Segue um mapa com a localização de algumas:

\section{Figura3:Localização de estabelecimentos de comércio de artigos religiosos em Natal - RN}

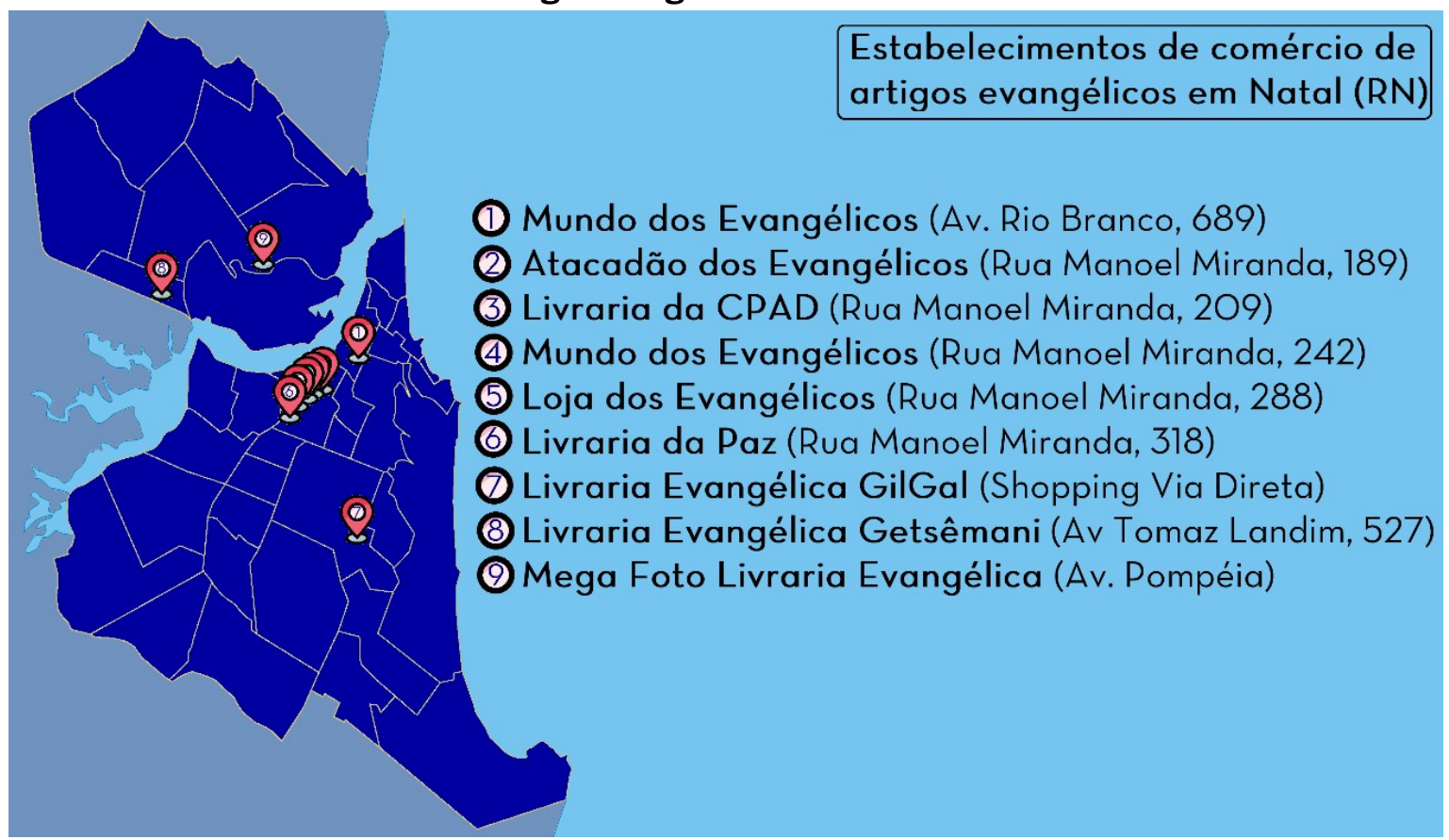

Fonte: Produzida pelo autor (2021), a partir de pesquisas anteriores (Costa, 2019; Costa, Santos, Rocha Neto, 2018).

O eixo que ficou por último talvez seja o principal: as mídias ${ }^{7}$. Assim como as lojas, elas potencializam toda a circulação descrita anteriormente, mas em uma escala muito maior. E por mídia aqui, é preciso uma compreensão bem larga. Dispositivos e suportes de informação como Livros, Panfletos, CDs, DVDs, pendrives, cartões de memória, drives externos são também, ao seu modo, meios 
de acessar informações. Esses suportes de mídia fazem parte da influência mútua entre evangélicos. Essa influência é maior com as mídias de larga escala, como a TV e o rádio. Há programas vinculados a igrejas locais em canais de TV e estações de rádios potiguares, só que no caso do rádio há também estações propriamente evangélicas em Natal. A mais conhecida é a Nordeste Evangélica FM 92.5, mas é provável que existam muitas outras, inclusive algumas "piratas", ou seja, sem registro oficial. Tais mídias fazem com que os crentes nem precisem mais do contato físico para se influenciar, algo que se amplia quando entra a internet e as mídias sociais, como WhatsApp, Facebook, Instagram e YouTube. Sua combinação com tudo o que foi descrito antes, gera uma rede gigantesca de influência mútua, que é autônoma em relação às igrejas. O resultado é a figura a seguir:

Figura4:Diagrama de ilustração de um circuito evangélico O CIRCUITO EVANGÉLICO

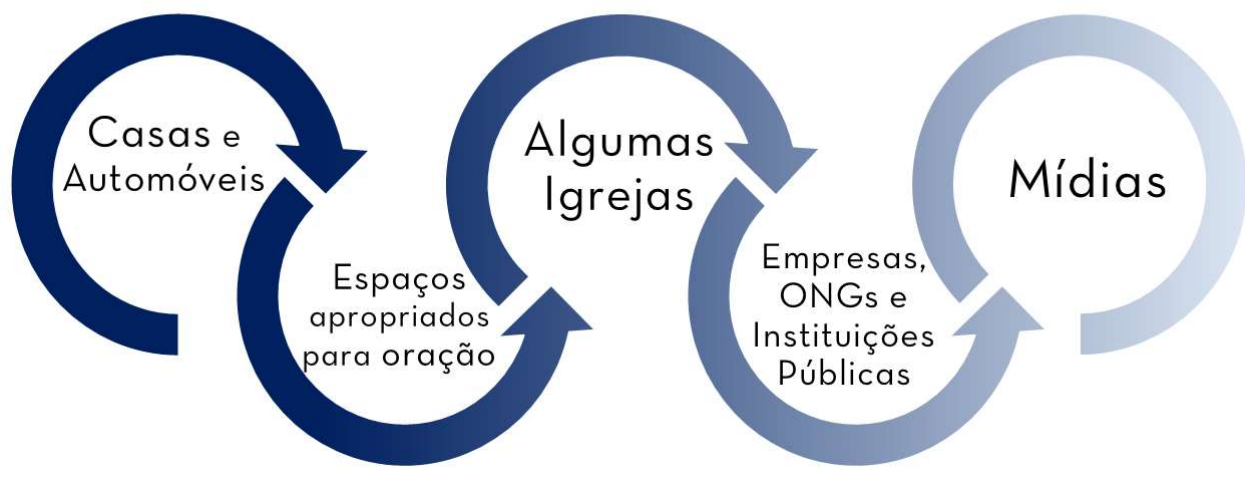

Fonte: Produzida pelo autor com um recurso do PowerPoint, em ago. 2020.

Sendo assim, ser crente em Natal - RN, assim como em muitas regiões metropolitanas do Nordeste ou do Brasil, não é apenas ser membro de alguma igreja protestante ou pentecostal, mas também estar em relação com um circuito evangélico. O que ocorre a contragosto de alguns, pois a circulação não é livre, mas fortemente influenciada por grupos evangélicos específicos que fazem valer sua hegemonia, principalmente através das mídias. De toda forma, sobretudo em ambiente urbano, mas não só, o circuito evangélico tornou-se tão parte da experiência de ser crente quanto as próprias igrejas. Aliás, talvez esteja aí uma chave para entender os evangélicos que estão optando por ficar um pouco mais afastados das denominações. Elas não têm o monopólio das referências de fé e, em meio a isso, não está nada fácil ser pastor. Cada líder tem que dividir a atenção 
dos membros da igreja com muitas outras referências que não estão sob seu controle.

Mas a opção dos "desigrejados" está mais para exceção do que regra. O que os crentes geralmente fazem não é escolher entre o circuito e a sua igreja, mas combinar as duas dimensões. Exercitam sua fé em uma espécie de multiverso. Às reuniões comuns de sua igreja se vai quando se quer algo constante, mais perene, uma rotina; e ao circuito se vai quando busca uma novidade, o fortuito, algo incomum, extraordinário. Vivem em experiência circular, como ilustra a figura abaixo:

\section{Figura5:Ilustração da conexão entre o circuito evangélico e as igrejas O MULTIVERSO EVAGÉLICO}

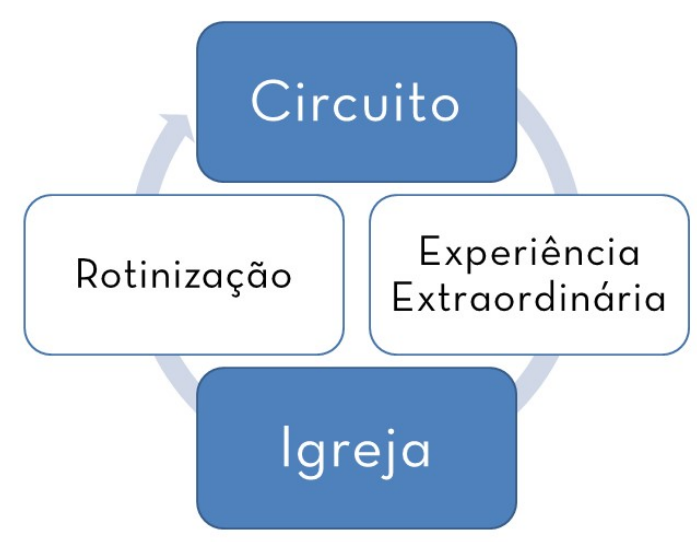

Fonte: Produzida pelo autor com um recurso do PowerPoint, em ago. 2020.

\section{Fechando um circuito, abrindo uma discussão}

Essa descrição pode ser especialmente didática para entender fatos semelhantes que acontecem Brasil afora. Como dito anteriormente, o Nordeste tem suas questões, mas ainda assim está acompanhando a transição religiosa do país. O que é diferente nesse caso é que crente nordestino parece gostar muito de praia. Esse é só um gracejo para ilustrar. O que está em jogo é a urbanização que, via de regra, se dá a partir do litoral. Em toda a costa nordestina, onde se encontram os centros administrativos, a hegemonia católica está mais ameaçada com uma maior presença evangélica.

A presença evangélica em Natal (RN) está articulada com muitos elementos urbanos facilmente identificados em outras cidades da região. Sendo assim, po- 
demos assumir que existe um circuito evangélico em cada região metropolitana nordestina à espera de descrição. A capital potiguar é um caso que ilumina como esse mapeamento pode começar. Quanto mais urbanizado é um local, mais a descrição feita nesse artigo pode iluminar a forma como os evangélicos se fazem presentes.

A ideia de circuito evangélico, como algo que surge em paralelo às igrejas, pode até deixar alguma lacuna, mas é um recurso útil para amarrar as informações, permitindo conhecer um pouco mais das cidades e dos próprios evangélicos que cada vez mais se declaram como tal, sem a preocupação de se referir a alguma igreja ou denominação específica.

Independente da autodeclaração religiosa, é bem provável que o Nordeste, assim como a capital potiguar, esteja repleto de pessoas assim. Cuja igreja é apenas um dos lugares em que a religião acontece. Não o único, talvez nem o principal. A fé desse tipo é mediada por diferentes equipamentos da cidade e nós passamos por eles todos os dias, mas nem sempre nos damos conta dessa dinâmica religiosa à nossa volta. Estamos prenhes de instrumentos analiticos que nos permitam aperceber disso e, percebendo, teorizar sobre. Quiçá a ideia de circuito possa sensibilizar a nossa percepção e aguçar nossas proposições teóricas.

\section{Referências bibliográficas}

ALVES, José Eustáquio Diniz; BARROS, Luiz Felipe Walter; CAVENAGHI, Suzana. A dinâmica das filiações religiosas no Brasil entre 2000 e 2010: diversificação e processo de mudança de hegemonia. Rever. São Paulo: PUC-SP, ano 12, n. 5, jul.-dez. de 2012. p. 145-174.

BEZERRA, Josué Alencar. Rede urbana interiorizada: novas conformações do território no Nordeste Brasileiro. Sociedade \& Natureza. Uberlândia: UFU, v. 32, junho de 2020. p. 392-403.

BOURDIEU, Pierre. O campo político. Revista Brasileira de Ciência Politica. Brasília: UnB, v. 5, n. 1, jan.-julho de 2011. p. 193-216.

BOURDIEU, Pierre. Gênese e estrutura do campo religioso. A economia das trocas simbólicas. $6^{\circ}$ ed. São Paulo: Perspectiva, 2007. p. 27-78.

BOURDIEU, Pierre. Os usos sociais da ciência: por uma sociologia clínica do campo científico. São Paulo: Editora UNESP, 2004. p. 17-29.

COSTA, Waldney. Curtindo a presença de Deus: religião, lazer e consumo entre crentes e canções. Tese (Doutorado em Ciência da Religião). Juiz de Fora: UFJF, 2019. 
COSTA, Waldney; SANTOS, Cláudio; ROCHA NETO, José. A presença pública das religiões na capital potiguar através de lojas de artigos religiosos. Congresso Nordestino de Ciências da Religião e Teologia, 6. Maceió - AL, 2018. Anais... Maceió: $\quad$ UFAL, $2018 . \quad$ Disponivel em https://www.doity.com.br/anais/ivcncrt/trabalho/65 707. Acesso em 3 de outubro de 2021.

CUNHA, Magali Nascimento. Do púlpito às mídias sociais: evangélicos na política e ativismo social. Curitiba: Appris, 2019.

CUNHA, Magali Nascimento.A explosão gospel: um olhar das ciências humanas sobre o cenário evangélico no Brasil. Rio de Janeiro: Mauad X: Instituto Mysterium, 2007.

DAMATTA, Roberto. Fé em Deus e pé na taboa: ou como e por que o trânsito enlouquece no Brasil. Rio de Janeiro: Rocco, 2012.

DIAS, Zwinglio; PORTELLA, Rodrigo; RODRIGUES, Elisa. Protestantes, evangéli$\cos e$ (neo) pentecostais: história, teologias, igrejas e perspectivas. São Paulo: Fonte Editorial, 2013.

GIUMBELLI, Emerson. Símbolos religiosos em controvérsias. São Paulo: Terceiro Nome, 2014.

MAFRA, Clara. Os evangélicos. Rio de Janeiro: Jorge Zahar Ed., 2001.

MAGNANI, José Cantor. Da periferia ao centro: trajetórias de pesquisa em antropologia urbana. São Paulo: Editora Terceiro Nome, 2012.

MALINOWSKI, Bonislaw. Introdução. CASTRO, Celso. Textos básicos de Antropologia: cem anos de tradição: Boas, Malinowski, Lévi-Strauss e outros. Rio de Janeiro: Zahar, 2016. p. 93- 114.

MARIANO, Ricardo. Neopentecostais: sociologia do novo pentecostalismo no Brasil. São Paulo: Edições Loyola, 1999.

MARIZ, Cecília; GRACINO JÚNIOR, Paulo. As igrejas pentecostais no Censo 2010. TEIXEIRA, Faustino; MENESES, Renata (org.). Religiões em movimento: o Censo de 2010. Petrópolis: Vozes, 2013. p. 161-174.

McGUIRE, Meredith. Lived religion: faith and practice in everyday life. New York: Oxford University Press, 2008.

MENDONÇA, Antônio Gouvêa. O celeste porvir. a inserção do protestantismo no Brasil. $2^{\circ}$ ed. São Paulo: Edições Paulinas, 1995.

MENESES, Renata. Às margens do Censo de 2010: expectativas, repercussões, limites e usos dos dados. TEIXEIRA, Faustino; MENESES, Renata (org.). Religiões em movimento: o Censo de 2010. Petrópolis: Vozes: 2013. p. 331-346.

SANCHIS, Pierre. O campo religioso contemporâneo no Brasil. PASSOS, Mauro; PEREZ, Léa Freitas (org.). Religião, cultura e identidades: matrizes e matizes. Petrópolis: Vozes, 2018. 
VAN DEN BERG, Irene (org.). Memória religiosa da cidade de Natal: coletânea de ensaios. Natal: RN Editora, 2021.

\begin{abstract}
${ }^{1}$ A fim de padronizar e evitar qualquer confusão nas comparações, os dados mobilizados no texto ficaram restritos aos Censos realizados pelo IBGE, entretanto cabe registrar que outros organismos têm realizado estatísticas mais recentes que estimam que a proporção de evangélicos na população brasileira segue em crescimento. É o caso do Latinobarômetro que em 2018 estimou essa proporção em 25,7\% e do Datafolha que em 2019 estimou em $31 \%$. Latinobarômetro está disponível para consulta em https://www.latinobarometro. org/latOnline.jsp; Datafolha foi noticiado em https://g1.globo.com/politica/noticia/2020 /01/13/50percent-dos-brasileiros-saocatolicos-31 percent-evangelicos-e-10percent-nao-tem-religiao-diz-datafolha.ghtml. Acessos em 3 de outubro de 2020.

2 O processo tardio de urbanização do Nordeste faz com que os grandes centros de comando, geralmente localizados mais ao litoral, ainda ditem muito do processo, mantendo uma certa hierarquia face aos centros intermediários que compõem a rede urbana interiorana de constituição recente (Bezerra, 2020). Isso significa que nem todas as regiões metropolitanas do Nordeste estão na mesma etapa de urbanização. Aquelas constituídas no entorno de centros regionais do interior, embora muito importantes para a região, ainda não experimentam as dinâmicas da metropolização por completo. Por isso a análise se ateve às Regiões Metropolitanas do entorno das capitais.

${ }^{3}$ No caso de Grande Teresina, não se trata de Região Metropolitana, mas Região Integrada de Desenvolvimento, já que compreende não só municípios do Piauí, como também do Maranhão.
\end{abstract}

${ }^{4}$ Para uma discussão sobre as características das denominações mais presentes no Brasil, sugiro a consulta Dias, Portella e Rodrigues (2013).

5 Para uma discussão sobre as demais declarações religiosas que se destacam em Natal (RN), sugiro a consulta a Van den Berg (2021).

6 A título de exemplo, tem-se o noticiado em: Bandidos estupram jovem em dunas de Jenipabu - 14/05/2011 - Notícia -Tribuna do Norte. Acesso em 3 de outubro de 2020.

${ }^{7}$ Para aprofundar a discussão sobre o papel das mídias no crescimento evangélico, sugiro a consulta a Cunha $(2007 ; 2019)$.

Recebido em 31/08/2021

Aceito para publicação em 17/09/2021 


\section{Narrativas e histórias sobre o início da Umbanda em Teresina}

Narratives and historiesabout the beginning of Umbanda in Teresina

Ariany Maria Farias de Souza*

Regina Weber ${ }^{* *}$

https://doi.org/10.29327/256659.12.2-8

\section{Resumo:}

Este artigo objetiva discutir como ocorreu o processo de constituição da religiosidade umbandista em Teresina a partir do movimento de integração com outras práticas religiosas, considerando o conceito de mudança cultural. Para tanto, foram descritas e analisadas diferentes narrativas sobre os primeiros anos da Umbanda em Teresina que se referem à Joaninha do Pontal e Maria Piauí. Por fim, concluiu-se que as diversas versões sobre o surgimento da Umbanda em Teresina nos revelam a influência de vários grupos e matrizes religiosas e culturais junto aos grupos de umbandistas que convivem na capital.

Palavras-chave: Umbanda. Teresina. Narrativas.

Abstract:

This article aims to discuss how the process of constitution of Umbanda religiosity in Teresina city has occurred from the integration movement with other religious practices, taking into consideration the concept of cultural change. For that, different narratives about the first years of Umbanda in Teresina related to Joaninha do Pontal and Maria Piauihave been described and analyzed. Finally, it is possible to conclude that the different versions of the appearance of Umbanda in Teresina reveal the influence of various religious and cultural groups and matrices on Umbanda groups that live together in the city.

Keywords: Umbanda; Teresina; Narratives.

\section{Introdução}

Nesse texto priorizamos seguir a linha que entende "os fenômenos religiosos como via de acesso à compreensão da sociedade brasileira” (MONTERO, 1999, p. 331). Dessa forma, partimos do pressuposto de que todos os elementos sociais se encon-tram imbricados no cotidiano dos sujeitos e dizem respeito à sua experiência, mas não somente a isso. Concordamos, ainda, que o "movimento das identidades reli-giosas e das questões religiosas em direção ao centro da vida

"Mestre em Antropologia pela Universidade Federal do Piauí (UFPI). Docente do Instituto Federal de Educação e Tecnologia do Piauí - Campus Picos. E-mail: arianymaria@hotmail.com.

** Doutora em Antropologia Social pela Universidade Federal do Rio de Janeiro (UFRJ). Docente Titular na Universidade Federal do Rio Grande do Sul (UFRGS). E-mail: regina.weber@ufrgs.br. 
social, política e até econômica talvez esteja disseminado e crescendo, em escala e importância” (GEERTZ, 2001, p. 164). Assim, essas questões e identidades estão cercadas pela variedade da experiência religiosa e não podem ser uniformemente descritas.

Seguindo nessa trilha, buscamos nos afastar da ideia que entende as religiões como totalidades culturais e que as enxerga como identidades únicas e herméticas, sendo nosso interesse mostrar o que salta ao discurso oficial sobre a origem da Umbanda no Piauí a partir da análise de sua composição múltipla. A religiosidade umbandista é composta a partir de uma sintese: ela causa estranhamento, promove a elaboração e a reelaboração de novos sentidos. O seu processo de constituição age nas fronteiras, incorporando traços de outros cultos e religiões, como: kardecismo, cristianismo, crenças indígenas e africanas. A mistura entre esses diversos traços compõem a Umbanda e essa forma de vê-la coloca a análise na contramão da ênfase na pureza e no essencialismo.

Entendendo a religião relacionada com a cultura ressaltamos a consideração de Peter Burke em sua obra Cultura popular na Idade Moderna (1989) que nos fala que a cultura é um sistema com limites muito indefinidos. O historiador comenta, ainda, uma das maiores contribuições de Roger Chartier ao discutir hábitos culturais populares:

É ter essa indefinição em mente e assim considerar que não faz
sentindo a busca pela identificação do que venha a ser cultura
popular levando em consideração apenas a distribuição de objetos
culturais, porque esses objetos são usados ou apropriados para as
suas próprias finalidades, que podem ser múltiplas e que podem
ocorrer por diferentes grupos sociais (BURKE, 1984, p. 15).

A Umbanda expressa a sua pluralidade ritual e litúrgica a partir das influências que recebe de outras matrizes religiosas e os terreiros são entendidos como "o único e principal fundamento de sua liturgia, de suas crenças, não tendo nada acima que a normatize em uma instância superior" (LEITE, 2018, p. 32). Portanto, mesmos os terreiros que mantêm vínculos formais com as federações de umbanda "não frequentam as sedes da federação à procura de orientação ético-doutrinária e ritual. Pelo contrário, são zelosos de suas prerrogativas, afirmando que a linha do trabalho é do pai de santo" (NEGRÃO; CONCONE, 1985, p. 75).

No entanto, apesar da diversidade em sua composição religiosa e na possi- 
bilidade de adaptações nas práticas e rituais nos terreiros, é possivel considerar alguns elementos que são capazes de identificar a religiosidade umbandista. Con-cordamos com Patrícia Birman (1985, p. 26) quando a autora afirma que mesmo havendo diferenças sensiveis entre os terreiros no modo de se praticar a religião, "elas se dão em um nível que não impede a existência de uma crença comum e de alguns princípios que são respeitados por todos".

Para Leite (2018, p. 48), existe o "reconhecimento de fronteiras capazes de demarcar se uma prática religiosa está ligada ou não à Umbanda". O autor comen-ta que para um terreiro ser considerado de Umbanda ele deve praticar o processo de incorporação espiritual, realizar atendimentos e reconhecer a existência e, em alguns casos, cultuar guias e entidades consideradas tradicionais como Pretos Velhos, Exus, Caboclos e Crianças, cada um com suas características (LEITE, 2018, p. 48-49).

Consideramos que "a religião transcende a barreira do individual e da experiência para fazer parte do social" (GEERTZ, 2001, p. 156) e entendemos que é nesse transitar que se formam as novas condutas religiosas. Assim, os fiéis umbandistas formam um grupo social que é reforçado pelos laços da religião e, em alguns casos, da etnicidade. Porém, a etnicidade não constitui uma condição pri-meira para que os sujeitos possam aderir à religião umbandista. A etnicidade aqui relaciona-se à ancestralidade que é acionada por alguns desses espaços na cons-trução de sua identidade. A religião pode ser entendida como um reforço da identidade e como um sistema permeável.

Os espaços onde é praticada a religiosidade umbandista possuem diversas nomenclaturas. Ao nos referirmos aos registros oficiais desses espaços religiosos adotamos a denominação tendas. Segundo Negrão (1993, p. 114), "são essas as instâncias criativas do culto onde a umbanda é vivida em seu cotidiano encantado de crenças e práticas mágicas, voltado para as necessidades de seu público interno".

Burke (1989, p. 17) utiliza como exemplo as diferentes nuances em torno do termo cultura ao longo dos anos para considerar que determinados aspectos da vida social e material dos grupos vão mudando ao longo dos tempos e que isso sugere também uma mudança de valores. Entendemos, assim, que à medida que mudam as relações entre os grupos, mudam os interesses e a forma como se apropriam das práticas e do conjunto de valores e símbolos. O historiador afirma, ainda, que "as mudanças culturais passam por mudanças nas atitudes, nas concepções e nos interesses dos grupos e dos sujeitos que ocorrem ao longo 
dos anos e que esse não é um processo estático" (BURKE, 1989, p. 16).

Essas mudanças são responsáveis, ainda, por influenciar o cotidiano, as representações e o saber fazer desses sujeitos. Dito isso, adiante discutiremos como se deu o processo de constituição da religiosidade umbandista em Teresina a partir de um movimento de integração com outras práticas religiosas, consideran-do o conceito de mudança cultural.

\section{Anotações sobre práticas religiosas de matrizes africanas em Teresina}

Para entender as configurações culturais, identitárias e territoriais das reli-giosidades de matrizes africanas e de seus praticantes nos dias atuais é fundamen-tal que encaremos o desafio de conhecer os seus caminhos e trilhas no território teresinense para, então, nos aproximarmos de suas origens e linhagens. Neste âmbito, conhecer os fundadores e/ou fundadoras das religiões afro-brasileiras na cidade, assim como suas tradições e ancestralidades religiosas, ajuda a refletir sobre a trajetória histórico-cultural dos fiéis de Umbanda em Teresina.

As vivências religiosas tendo por base as matrizes africanas acompanham a edificação e o desenvolvimento da cidade de Teresina e as transformações que seu espaço vai sofrendo ao longo dos anos. Mergulhando mais fundo na história das culturas religiosas afro-brasileiras na cidade, a historiografia nos leva às primeiras décadas do século XX, quando "o pontal formado pelo encontro dos rios Parnaíba e Poti era referência segura para descanso" (LIMA, 2014, p. 14) de viajantes e tropas que seguiam cortando os sertões, indo ou voltando da capitania do Maranhão para o Piauí, em direção a alguma vila ou a muitas fazendas, localizadas ao longo do Parnaíba ${ }^{1}$ (LIMA, 2014, p. 15). Os registros históricos sobre a Barra do Poti descre-vem essa região como um local de natureza exuberante, aprazivel, com terrenos saudáveis e férteis, em posição vantajosa sobre as margens do Parnaíba e Poti, ${ }^{2}$ como podemos constatar na Figura 1: 
Figura 1 - Localização da região do encontro dos rios Parnaíba e Poti que atualmente abriga o Parque Encontro dos Rios, em Teresina

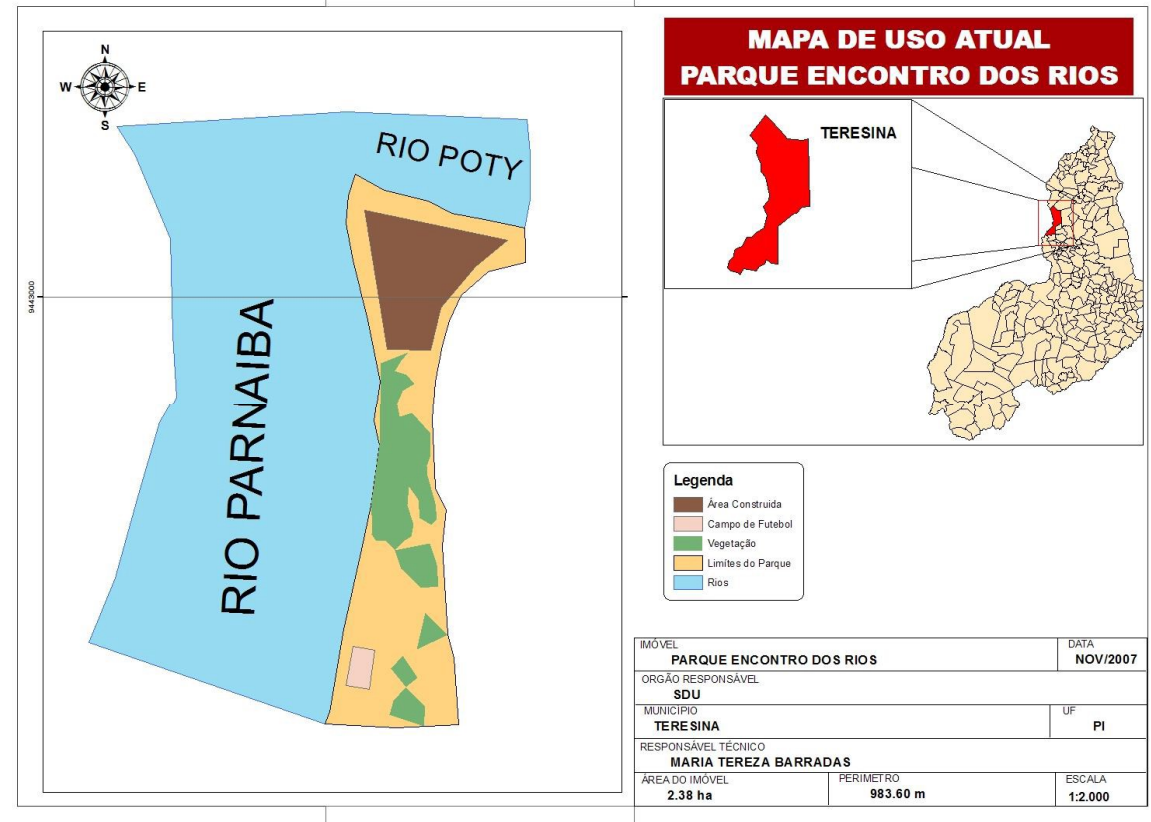

Fonte: VIEIRA \& SILVA, 2009, p. 09

Chaves (1998, p. 153) lembra que no final do século XVII, habitavam nesta região, nas proximidades do rio Parnaíba, "diversos povos indígenas, dentre eles, os Potis",3 reconhecidos por alguns povos de terreiros teresinenses como os verdadeiros donos daquela terra. Os caboclos de pena, ${ }^{4}$ como são chamados os espíritos desses povos em religiões de matrizes africanas, "cuidavam de viajantes e de animais que chegavam exaustos e feridos naquelas paragens" (LIMA, 2014, p. 18). Muitos desses povos resistiram e muitos foram rendidos, passando a conviver com o colonizador. A partir daí nota-se as fusões étnico-cultural do povo piauiense e brasileiro.

$\mathrm{Na}$ região da Barra do Pontal também "existia a presença de populações negras, escravizadas e fugitivas" (LIMA, 2011, p. 15). Chaves afirma, ainda, que, no século XVIII, na área do encontro dos rios Parnaíba e Poti, escondido entre as matas, às margens do rio Poti, havia um "mocambo de escravizados e escravizadas que resistiram por muitos anos à perseguição de senhores e 
fazendeiros da região" (LIMA, 2011, p. 15). Negros e negras de diferentes nações e partes do Piauí, ao longo do tempo, teriam fugido/migrado para o Pontal, abrigando-se no mocambo e construído uma comunidade. Entretanto, em julho de 1779, "a resistência negra sangrará no Pontal da Barra do Poti" (LIMA, 2014, p. 15). O mocambo, embora fortalecido, não resistiu ao confronto com os militares, o que resultou na morte de negros e negras que tinham o lugar como referência de proteção e abrigo.

De acordo com o Recenseamento Geral do Império, Teresina, em 1872, "possuía uma população negra correspondente a $71 \%$ dos seus habitantes" (SILVA, 2008, p. 13), sendo a sociedade piauiense desse período formada em sua maioria por povos negros, libertos e/ou escravizados. Teresina era, então, em seus anos iniciais, uma capital com uma "população de características muito distantes dos padrões considerados típicos da cultura dominante, branca e europeia” (SILVA, 2008, p. 14).

A composição demográfica-étnica-cultural da sociedade teresinense duran-te o século XIX relaciona-se ao processo de formação/edificação da cidade de Tere-sina e de significação da cidade e seus espaços/lugares, principalmente para a ca-mada pobre e negra da população piauiense que fugia do sofrimento da escravidão de fazendas no interior do Piauí para este novo núcleo urbano. A principal esperança era de conquistar a sua liberdade e de construir na nova cidade uma vida melhor. Assim, uma vultosa população de negros e negras dirigia-se a Tere-sina, criando "espaços de sociabilidade, notadamente marcados pela cultura e identidade negras" (SILVA, 2008, p. 38).

Durante o século XIX, um contingente significativo de homens e mulheres negras foram trazidos de fazendas piauienses para trabalhar nas obras públicas da cidade:

O povo negro foi responsável por boa parte da construção/edificação de Teresina, desempenhando papel ativo na construção de igre-jas, casas e prédios públicos no espaço urbano. Por meio do traba-lho, negros e negras foram, assim, os principais responsáveis pela construção social, espacial e cultural de Teresina e da sociedade teresinense (SOUSA, 2012 apud CARMO, 2017, p. 88).

Na região da Freguesia das Dores concentrava-se o maior percentual de pessoas negras escravizadas e libertas em Teresina. Esse espaço em que se 
encontravam muitas pessoas recém-chegadas a Teresina era conhecido como Rua dos Negros, denominado oficialmente como Rua Augusta (SILVA, 2008, p. 117). Nessa rua, "a população parda e preta, com suas celebrações festivoreligiosas, estabeleceram referências de vida que mudaram o cotidiano e a paisagem cultural da cidade" (SILVA, 2008, p. 117). Na concepção de Silva (2008, p. 118), essas festivi-dades, também chamadas de batuques, ${ }^{5}$ demarcavam o pertencimento étnico-cultural-religioso de um povo e constituíam-se em espaços coletivos de lazer e diversão, de resistência negra e de intercâmbios culturais. As atividades festivo-religiosas de tradição africana na cidade compunham as identidades social/cultu-ral/religiosa da sociedade teresinense da época: nessas festas e ritos, negros e negras faziam uso de patuás e de ervas, benzimentos e curas, jogos de búzios e contas para a proteção, orações e feitiçarias.

Para autoridades policiais e eclesiásticas da cidade, os batuques eram "um ato de feitiçaria, ligado ao fanatismo e à superstição popular de um povo pobre e analfabeto" (SILVA, 2008, p. 100), que os aceitava e praticava com facilidade. Durante o século XIX já se tinha, na cidade, indícios da realização de atividades tidas como mágico-religiosas por pessoas negras em Teresina, dentre elas, aquelas nomeadas pelas pessoas brancas como curandeirismo e manifestações de feitiçaria. Essas, por sua vez, eram reiteradamente combatidas e controladas pelo poder público munici-pal. No tocante ao cumprimento de atividades mágicoreligiosas, havia batidas policiais a residências de negros e negras, escravizados ou libertos, praticantes de manifestações religiosas negras, e inquéritos policiais que tratavam do crime de charlatanice. Havia, ainda, casos de homens e mulheres negros, com atribuições de líderes religiosos, que supostamente praticavam curandeirismo, reunindo em sua casa grupos escravizados, libertos e "pessoas de grandes circunstâncias" (SILVA, 2008, p. 100).

\section{A umbanda no Brasil}

Atualmente, os pesquisadores de religiões afro-brasileiras não possuem um consenso sobre o ano e o local de fundação da Umbanda no Brasil, embora a literatura geralmente aponte "a década de 1920 como o marco inicial da Umbanda no Brasil" (Silva, 2005, p. 106). Em uma sociedade moderna e racional para os padrões da época, a religiosidade umbandista, como culto organizado, nasce a partir de derivações e readaptações originadas no interior do kardecismo. A criação da Tenda Espírita Nossa Senhora da Piedade, no Rio de Janeiro, por Zélio Fernan-dino de Moraes e seu grupo, pode ser "considerada um dos 
primeiros centros de Umbanda que conscientemente usou esse nome" (BROWN, 1985, p. 11). A autora informa que esse grupo era composto por "kardecistas insatisfeitos que passaram a buscar os espíritos e divindades africanas e indigenas presentes na macumba" (BROWN, 1985, p. 11).

O grupo de Zélio era composto por pessoas predominantemente vindas dos setores médios da sociedade. ${ }^{6}$ Segundo Brown (1985, p. 11), "eles achavam os ritu-ais da macumba mais estimulantes e dramáticos que os do kardecismo" mas, em contrapartida, consideravam "repugnantes os rituais africanos que envolviam sacrificios de animais e a presença de espíritos considerados diabólicos". Entre seus anos iniciais e o Primeiro Congresso Umbandista (1941), no Rio de Janeiro a umbanda esteve ligada a alguns aspectos caros ao kardecismo. Dois temas são considerados centrais nas atas elaboradas após esse evento que são: a criação de uma umbanda desafricanizada; e "Um esforço para branquear ou purificar a um-banda, desassociando-a da África primitiva e bárbara" (BROWN, 1985, p. 11). Obser-vamos, dessa forma, uma tentativa de selecionar elementos que seriam mais próxi-mos aos fundamentos do que viria a ser a umbanda que se formava enquanto religião.

Aproximando-se de uma perspectiva que considera a Umbanda enquanto transformação dos Candomblés da Bahia, Roger Bastide (1971) nos fala que a crescente urbanização do Brasil no início do século XX dá origem a comunidades religiosas marcadas pelo individualismo moderno e com influências do espírito científico da época. Kaitel (2019, p. 34-35), comentando a perspectiva de Bastide, afirma que esse movimento foi:

Capaz de promover no sudeste a formação da Umbanda, a partir de uma aproximação da macumba carioca - religião de matriz africana surgida nas comunidades marcadamente pobres e negras do Rio de Janeiro no século XIX onde atendimentos eram realizados por sacerdotes incorporados com espíritos - com religiões 'brancas' como o kardecismo.

Alguns estudiosos, como o sociólogo Lísias Nogueira Negrão (1993, p. 116), apontam a Umbanda como religião mediúnica que incorpora em suas doutrinas "elementos do catolicismo (fé, esperança e caridade), da filosofia kardecista, os orixás e entidades dos Candomblés e os encantados de influências indígenas", em diferentes linhas e que mostra-se como uma religião universal 
que "incentiva a mobilidade social de seus adeptos e adeptas, à medida que se forma, buscando reunir raças, grupos étnicos e classes sociais que constituem o povo brasileiro" (PRANDI, 1995, p. 71).

Definir o termo "umbanda" ou as práticas de seus fiéis não é nosso objetivo. Nosso desafio passa por entender como ao longo dos anos seu significado vem sendo relacionado a um culto religioso capaz de "reconhecer e sintetizar elementos históricos e sociais brasileiros de matrizes negras, indígenas e ocidentais" (NEGRÃO, 1993, p. 113). Dessa forma:

Compreender a formação da umbanda enquanto manifestação religiosa implica diretamente na compreensão da formação sóciocultural do povo brasileiro e de suas estratégias de ressignificação de elementos originários de outras práticas culturais (BRANDIM, 2014, p. 263).

Durante as primeiras décadas do século XX adeptos da umbanda sofreram forte perseguições, pois essa religião ainda era pouco conhecida e em geral identificada como de origem afro-brasileira. Devido à sua ligação histórica com o sistema escravista, poderia lhes garantir uma ampla perseguição e, em alguns casos, extorsões pelos agentes do Estado contra alguns chefes de terreiros. Segundo Diana Brown (1985, p. 13), "em 1934 no Rio de Janeiro alguns grupos de umbandistas ficaram sob jurisdição policial e seus espaços religiosos só poderiam funcionar com o registro na polícia". O registro do terreiro teoricamente lhe dava garantia de prática legal, mas em contrapartida acabava atraindo a atenção da polícia para esses espaços, aumentando a possibilidade de intimidação e extorsão.

Até meados da década de 1940, a Umbanda foi presença constante nos noticiários policiais. O período do Estado Novo foi especialmente severo no que se refere à repressão dos terreiros. Obrigados a se "registrar nas delegacias de polícia, ficavam a mercê do pagamento de taxas de proteção e extorsões" (NEGRÃO; CONCONE, 1985, p. 44). A repressão policial enfrentada por alguns grupos foi um dos fatores que motivaram a organização de instituições formadas por representantes dessa religião que lutassem pela proteção dos terreiros.

A Umbanda em sua formação ao longo dos anos guarda relação com a racionalização presente na vida dos sujeitos urbanos e com o processo de mudança e modernização das cidades. Essa religião desponta como uma 
exigência e produto simbólico de uma sociedade "urbana, industrial e de classes, que se apoia em valores de modernidade ligados à racionalização e, principalmente, à moralização de práticas sociais, culturais e religiosas" (ORTIZ, 1999, p. 162).

Ao estudar como se deu o processo de integração e legitimação da religião umbandista no seio da sociedade brasileira, Renato Ortiz (1999) apresenta a pers-pectiva de entendimento desse fenômeno a partir do estudo da mudança cultural. Para Ortiz (1999), os valores religiosos afro-brasileiros vão se transformando para compor uma nova religião:

A sociedade global aparece então como modelo de valores, e modelo da própria estrutura religiosa umbandista. Isto faz com que as transformações do mundo simbólico afro-brasileiro se realizem sempre em conformidade com os valores legítimos da sociedade global. Valores como a moral católica, a racionalização, a escrita, se integram a outro tipo de moral e racionalidade, características estas dos cultos afro-brasileiros (ORTIZ, 1999, p. 15).

À medida que há um movimento de mudança cultural, as crenças e práticas afro-brasileiras se modificaram, tomando um novo significado na sociedade global. As mudanças nas relações sociais nos mostram, ainda, um desejo por parte dos setores médios brancos de modelar e controlar suas atividades. Os intensos esforços para dissociar a Umbanda da imagem afrobrasileira também estavam relacionados com o desejo de fuga das perseguições sofridas por esse grupo.

A Umbanda vai se modificando em suas práticas e doutrina, o que inicialmente previa a aproximação com elementos de outras religiosidades e que fosse capaz de representar a diversidade do povo brasileiro, passando por ajustes e modificações na direção de uma maior integração na sociedade moderna. Segundo Renato Ortiz (1999, p. 37-38), o movimento de embranquecimento da Umbanda foi uma das ações realizadas nesse sentido, e dizia respeito à "incorporação de elementos espíritas católicos e estrangeiros em cultos de origem africana que tinham como uma de suas principais características a magia", que aos poucos vai sendo deixada de lado. Porém, essa tese é entendida por Paula Montero (1999, p. 347) "como um determinismo social esquemático que não dá conta do fato da permanência viva do feiticeiro negro na umbanda", ou seja, a 
tentativa de siste-matização teológica empreendida pelos intelectuais umbandistas não corresponde ao que se observa nas práticas concretas dos terreiros.

A busca por uma aproximação com os padrões de racionalização vigentes na sociedade brasileira do início do século XX permitirá que a Umbanda incorpore às suas práticas alguns dos valores dominantes da época. O discurso normatiza-dor tentará se sobrepor às múltiplas práticas religiosas existentes na sociedade, sugerindo formas de unificar os cultos e visando a aceitação e o reconhecimento dessa religião no espaço público. Ressignificando símbolos e práticas culturais e religiosas nacionais, sob influências de um catolicismo cristão e de um espiritismo branco que, a princípio, moralizam a religião e seus guias, extirpando dos cultos e/ou rituais práticas religiosas consideradas primitivas (sacrificios de animais, ingestão de bebidas alcoólicas) que podem ofender os valores cristãos da sociedade (NEGRÃO, 1993, p. 120), a Umbanda se legitimou como "uma religião à moda brasi-leira" (SILVA, 2005, p. 125).

Bahia e Nogueira (2018, p. 54) analisam a disputa de narrativas em torno da construção do campo religioso umbandista entre as décadas de 1940 e 1950 no Rio de Janeiro e apontam para o resgate da ancestralidade negra feito por Tancredo da Silva Pinto (Tatá Tancredo), o principal representante da Umbanda Omolocô,7 uma concepção mais próxima à do candomblé. Em 1949, Tatá Tancredo cria a CEUB (Congregação Espírita Umbandista do Brasil), no Rio de Janeiro, e inicia um amplo processo de críticas aos intelectuais umbandistas que prezavam por uma umbanda mais afeita ao kardecismo e ao catolicismo. Portanto, ao recriar um local de origem africana para a umbanda, Tancredo foi responsável por desenvolver uma federação de umbanda, que tinha um olhar africanista para a religião, revalorizando a África em sua narrativa (BAHIA e NOGUEIRA, 2018, p. 69).

\section{Narrativas sobre os primeiros anos da umbanda em Teresina}

Até o final do século XIX não se reconheciam as práticas religiosas e culturais de povos negros escravizados ou libertos como expressões características daquilo que seriam denominadas religiosidades afro-brasileiras. Até então, as culturas negras na cidade de Teresina eram identificadas como ajuntamentos de pessoas negras e batuques. A literatura afro-teresinense sugere que somente nas 
primeiras décadas do século XX podemos falar em "marco inicial da Umbanda na cidade" (SOUZA, 2012, p. 6).

Sobre esse assunto, a memória sobre as celebrações negras na cidade identificam na área de encontro dos rios Parnaíba e Poti, território que faz parte da zona Norte da cidade, um terreiro de Umbanda que mais tarde passaria a ser a principal referência histórica contemporânea dos lugares de culto de matrizes afro-brasileiras. Trata-se da Tenda Espírita Santa Bárbara, fundada em 1932, pela senhora Joana Maciel Bezerra, mais conhecida como mãe Joaninha do Pontal. A mãe de santo passou a ser reconhecida no cenário religioso teresinense e piauiense como Mãe Joaninha do Pontal, em razão da localidade onde se encontrava instalada sua tenda. Como dito, "a Tenda de Santa Bárbara foi fundada no pontal formado pelo encontro dos dois principais rios do território piauiense, no Poti Velho" (LIMA, 2017, p. 50).

A primeira linha de explicação sobre os eventos que remetem ao início da Umbanda no Piauí fala sobre a chegada de Joaninha do Pontal à Teresina no início do século XX vinda do Ceará para iniciar um terreiro no Piauí. Essa interpretação foi formulada por José Soares de Albuquerque, ${ }^{8}$ que lançou mão de entrevistas com praticantes da Umbanda de Teresina com mais tempo de vivência entre 1960 e 1970, dando forma a uma narrativa que foi composta pelas memórias sobre algumas das práticas umbandistas mais antigas no Piauí. O fato da formulação de uma teoria que explicasse a origem da Umbanda no Piauí ter sido realizada durante esse período sinaliza a tentativa de elaborar uma história que abarcaria a totalidade da formação do movimento umbandista seguindo uma tendência de busca pela legitimação dessa religião junto à sociedade global, como explica Ortiz (1999, p. 164): “A antiguidade da religião umbandista é forjada pelos teóricos para se elaborar uma origem para a religião que é importante para a legitimação da religião".

Segundo José Soares de Albuquerque, "nos idos de 1919 aportou em Teresina, capital do Estado do Piauí, a senhora conhecida por Joaninha, advinda do vizinho estado do Ceará". Fugindo das perseguições religiosas neste estado, a senhora, que praticava ritos umbandistas, "trazia em sua bagagem vários santos, em vultos, e outros tantos de orixás" (ALBUQUERQUE, 1987, p. 161). Joana Maciel Bezerra seria, então, a responsável pela introdução do culto e de práticas umban-distas em Teresina. Mãe Joaninha do Pontal, como ficou popularmente 
conhecida, teria sido a precursora da Umbanda na cidade, organizando um culto com base nas características afro-religiosas mais atuais. Na Figura 2 podemos observar o mapa da região que hoje abriga o bairro Poti Velho, provável local de instalação da Tenda Espírita Santa Bárbara no início do século XIX em Teresina.

\section{Figura 2 - Mapa de localização do bairro Poti Velho de Teresina, Piauí}

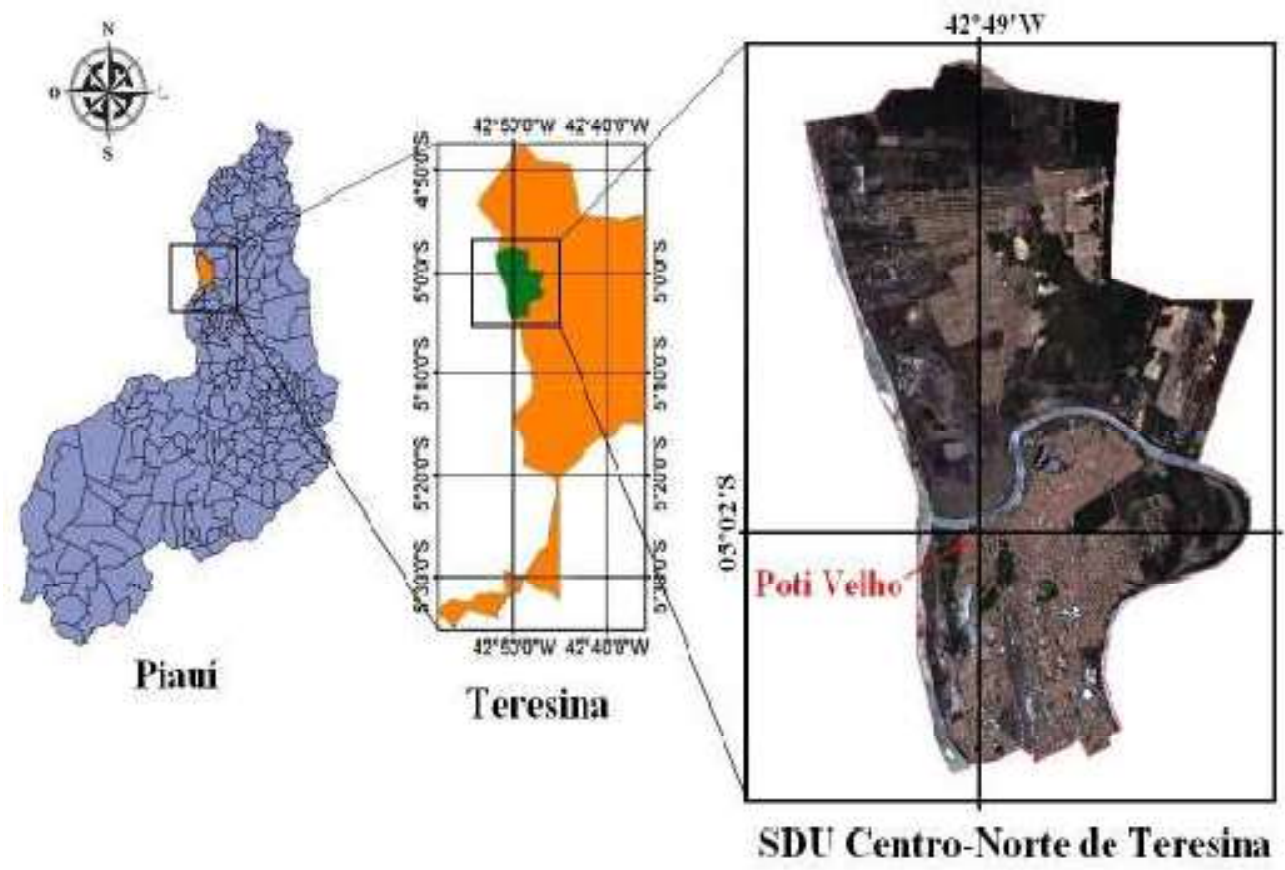

Fonte: Nogueira; Espindola; Carneiro, 2016, p. 28

Mãe Joaninha do Pontal trouxe para Teresina a significação simbólica das práticas e rituais da Umbanda, expressas nas vestimentas, nos ritos e no culto às entidades. Essa mãe de santo teria atribuído às práticas ligadas às afroreligio-sidades uma estrutura mágico-religiosa, "definindo liturgias nos ritos e ordenando, em um espaço físico considerado sagrado, práticas religiosas e culturais de tra-dição afro-brasileiras e ameríndia, até então dispersas na cidade" (LIMA, 2014, p. 17).

A literatura sobre religiosidade afro-teresinense revela que a Tenda Espírita Santa Bárbara, logo após a sua fundação, ganhou vários adeptos e adeptas, tornando-se também ponto de migração e de visitação de muitas pessoas, curiosos, religiosos e fiéis. Durante o período que se estabeleceu e viveu em Teresina, Mãe Joaninha do Pontal teria iniciado e formado muitos filhos e filhas de santo que, posteriormente, abriram suas próprias tendas na cidade. Mais do que introduzir as religiões afro-brasileiras na cidade, essa mãe de santo contribuiu 
para a formação de "pequenos núcleos da religiosidade umbandista em Teresina" (LIMA, 2017, p. 52). ${ }^{9}$ A partir dos relatos de pais e mães de santo com mais tempo de experiência na religião umbandista, foi possivel entender suas histórias sobre a formação de diversos filhos e filhas de santo que se iniciaram e se desenvolveram em suas casas e que mais tarde vieram a traçar seus próprios caminhos, ao montarem suas próprias tendas de umbanda, seguindo a sua missão de médiuns. ${ }^{10}$

Em pesquisa sobre a institucionalização da Umbanda no Piauí, Lima (2017) relata, a partir da tradição oral de umbandistas, outra versão da chegada da Umbanda na cidade. Sobre esse assunto, com base em narrativas orais, a mãe Joaninha do Pontal teria vindo de São Luís do Maranhão para o Piauí, vítima de intolerância religiosa. Ao chegar a Teresina, essa mãe de santo juntouse a um grupo de pessoas que "costumava exercer, na cidade, práticas de caráter religioso, entre elas, benzimentos e curas" (LIMA, 2017, p. 51).

Ainda em relação a notícias sobre a perseguição policial de Mãe Joaninha do Pontal, Albuquerque (1987) afirma que essa mãe de santo "era portadora de uma grandiosa força espiritual", visto que diversas patrulhas policiais que se deslocavam para a região do Pontal "com o objetivo de acabar com a festa umbandista" fracassaram em seu propósito. Muitas dessas patrulhas não encontravam o local onde estava edificada a Tenda de Mãe Joaninha, por se tratar de uma região próxima dos rios e de mata fechada e terminavam "rodando como verdadeiras baratas tontas" (ALBUQUERQUE, 1987, p. 161).

As perseguições a fiéis das religiões de matrizes africanas, que culminavam muitas vezes na invasão e destruição/desapropriação do espaço sagrado do terreiro e na prisão de adeptos e adeptas, popularmente chamados de filhos e filhas de santo, eram movidos, dentre outras razões, por discursos moralistas e civilizatórios, que priorizavam a lógica de dominação branca. Essas perseguições podiam ser vistas também nos terreiros em funcionamento nas primeiras décadas do século XX no Rio de Janeiro, como citamos anteriormente. Podemos acrescentar, ainda, que estes relatos sobre as primeiras manifestações religiosas umbandistas em Teresina, em sua maioria, associam suas práticas a traços de magia e feitiçaria. Nesse período, grande parte da sociedade brasileira e teresinense fazia parte da religião Católica Apostólica Romana, de forma que as práticas dos espaços de culto afro-religiosos não eram aceitos pelos católicos.

Apesar de entendermos que a Tenda Espírita Santa Bárbara faz parte dos 
recortes de memória dos umbandistas de Teresina e que possui relevância na com-posição de suas identidades, não acreditamos que essa seja a única versão sobre os primeiros anos da umbanda em Teresina.

Existem estudos diferentes da proposta apresentada por Albuquerque sobre a origem da Umbanda no Piauí. A historiadora Sabrina Lima, em entrevista realizada com o senhor Luiz Santos ${ }^{11}$, conhecido pai de santo teresinense, revela uma outra versão sobre os primeiros anos da Umbanda no Piauí. O entrevistado reconhece Joaninha como a primeira mãe de santo umbandista, mas identifica outra origem e práticas ritualísticas:

Seu Luiz nos relatou que seu avô abrigava em sua casa uma senhora como agregada, conhecida como Chica Galvão. Dona Chica Galvão era negra, rezadeira, descendente de escravizados, que prestava alguns serviços, tanto para a família do senhor Luís, quanto para a comunidade. Seus serviços consistiam em rezas para proteção e também serviços de parteira, 'aparando as crianças' da região. Seu Luís conta que conviveu com dona Chica Galvão desde muito pequeno, tendo ela falecido com cerca de 89 anos de idade, quando Luís teria entre 14 ou 15 anos (SANTOS, 2015, p. 53).

De acordo com o entrevistado, Chica Galvão contava em suas histórias que Joaninha do Pontal teria vindo de São Luís do Maranhão nas primeiras décadas do século XX, em 1920, aproximadamente, e se estabelecido em uma fazenda que ficava às margens do Rio Poti. Seu Luís acredita que Joaninha teria vindo ao Piauí "encomendada" 12 por alguém de poder para realizar serviços espirituais, especialmente de proteção e, provavelmente, pelo dono da fazenda em que ela teria montado seu terreiro.

Em contrapartida, o entrevistado conta que algumas pessoas, como a própria Dona Chica Galvão, mesmo antes da chegada de Joaninha em Teresina, já realizavam trabalhos que se aproximariam daqueles praticados em terreiros de Umbanda, como orações para se proteger do mal, curas diversas e outros. Estes eram detentores de conhecimentos mágicos, conhecidos como "ciências ocultas" (Santos, 2015). É possível, ainda, constatar em seus relatos que a maioria dessas pessoas, por causa das perseguições e do preconceito, atendiam de forma discreta em suas casas, nas chamadas mesas em quartos nas suas próprias residências, "atendendo apenas aos mais íntimos e pessoas conhecidas e não abertamente" (LIMA, 2017, p. 56).

Teresina localiza-se distante cerca de $170 \mathrm{~km}$ da cidade de Codó, no 
Estado do Maranhão, onde tradicionalmente pratica-se o Terecô, ${ }^{13}$ expressão de religiosidade presente em outros entes federativos de maneira "integrada ao Tambor de Mina e à Umbanda e que exerce influência em suas práticas religiosas" (FERRETTI, 2011, p. 92). O Terecô também é visto como "Encantaria de Barba Soêra ou Bárbara Soeira, entidade sincretizada no catolicismo com Santa Bárbara" (FERRETTI, 2011, p. 92). Essa expressão religiosa também pode ser chamada por Tambor da Mata, ou simplesmente Mata, termo utilizado em alusão à sua origem rural ou para diferenciar essa religiosidade da tradicional Mina surgida e praticada na capital, São Luís. ${ }^{14}$

Com relação ao surgimento da Umbanda no Piauí e na cidade de Teresina destacamos o nome da famosa terecozeira Maria Silva Lima, conhecida como Maria Piauí. Essa mãe de santo teria se tornado muito conhecida no Piauí e no Maranhão, fundando, em 1948, um terreiro na cidade de Codó (MA), onde é vista como "introdutora da umbanda" (FERRETTI, 2011, p. 179). A líder religiosa piauiense tornou ainda mais conhecido o cruzamento das linhas Terecô de Codó e Tambor de Mina, já praticado em São Luís, quando uma missão folclórica de São Paulo registrou uma música de terreiro de Maximiano, em 1938.15

À medida que descrevemos as diferentes narrativas elaboradas sobre os primeiros anos da religiosidade umbandista em Teresina podemos afirmar que em sua origem esses espaços religiosos são sempre liderados por mulheres migrantes que chegam à Teresina em busca de um local para vivenciar essa religiosidade de acordo com seus valores e partindo de suas experiências de vida. Levando em conta a forte influência das matrizes africanas e indígenas nas práticas religiosas dos anos iniciais em Teresina, podemos inferir que as duas mães de santo - Joaninha do Pontal e Maria Piauí - levam em consideração essas influências ao vivenciar a religiosidade umbandista na capital. Outro ponto bastante relevante que devemos destacar é o fato dos primeiros terreiros descritos nas narrativas aqui apresentadas terem sido instalados na região próxima aos rios Parnaíba e Poti, estando, assim, em acordo com a cosmologia umbandista que cultua a natureza e a proximidade com as matas e as águas.

\section{Conclusão}

Os detalhes analisados nos ensinam que não importa marcar uma origem comum para a religião umbandista, mas,, sim atentar-nos para os vários 
começos dessa prática religiosa. As reflexões apontam para a religiosidade umbandista como um objeto que vai para além da lógica moderna que aceita os mitos de origem e a ossificação do passado.

Portanto, mesmo com a variação nas versões contadas, não há dúvidas de que Joaninha do Pontal e Maria Piauí teriam se fixado na memória da comunidade umbandista como aquelas que teriam iniciado as práticas umbandistas na cidade. De toda forma, o objetivo desta reflexão foi entender os modos concretos em que os discursos sobre a origem da Umbanda no Piauí vão se constituindo enquanto parte de um movimento de integração de valores e práticas religiosas de diferentes grupos e como as mudanças culturais vão sendo responsáveis por influenciar na constituição da religiosidade umbandista que se forma no Piauí.

Partindo da experiência religiosa, não podemos entender que a constituição da história da religiosidade umbandista seja única, mas sim formada por diversos personagens, em suas vivências, memórias e desafios. À medida que mudam as relações sociais ao longo dos tempos, os diferentes grupos mudam seus interesses e a forma de se relacionar com seu conjunto de valores e simbolos, o que influencia diretamente em como reconhecem e se identificam com suas origens. As diversas versões sobre o surgimento da umbanda em Teresina nos revelam a influência de diversos grupos e matrizes religiosas e culturais junto aos grupos de umbandistas que convivem na capital. Assim, os mais diferentes grupos partindo de diferentes memórias e referenciais irão elaborar, à sua forma, uma narrativa que identifica as origens de sua religião.

\section{Referências bibliográficas}

ALBUQUERQUE, José Soares de. Dados históricos da Umbanda Piauiense. CARI-BÉ, Antônio Júlio Lopes. Obrigações para Oxóssi: Memórias Insólitas. Salvador: Imprensa Gráfica da Bahia, 1987.

BAHIA, Joana; NOGUEIRA, Farlen. Tem Angola na umbanda? Os usos da África pela Umbanda Omolocô. Revista Transversos. Rio de Janeiro: UERJ, n. 13, maioagosto, 2018. p. 53-78.

BARTH, Fredrik. O Guru, o Iniciador e Outras Variações Antropológicas. Rio de Jáneiro: Contra Capa, 2000.

BASTIDE, Roger. As religiões africanas no Brasil. São Paulo: Pioneira, 1971.

BIRMAN, Patrícia. O que é Umbanda?. São Paulo: Abril Cultural; Brasiliense, 1985. 
BRANDIM, Vivian de Aquino S. A umbanda no Maranhão: o Reino dos Encantados. PINHEIRO, Áurea P.; Falci, Miridan; LIMA, Solimar Oliveira (org.). Patrimônio e Cultura Negra. Vox Musei. Teresina: UFPI, 2014. p. 263-289.

BROWN, Diana. Uma história da Umbanda no Rio: Umbanda e Política. Cadernos ISER. Rio de Janeiro: ISER, n. 18, 1985.

BURKE, Peter. Cultura popular na Idade Moderna: Europa, 1500-1800. São Paulo: Companhia das Letras, 1989.

CARMO, Francisca Daniele Soares do. Povos de terreiro no contexto de intervenções urbanísticas: territórios sociais de religiosidades de matrizes africanas na zona Norte de Teresina - PI e o Programa Lagoas do Norte - PLN. Dissertação (Mestrado em Sociologia). Teresina: Universidade Federal do Piauí, 2017.

CHAVES, Joaquim. Obras Completas. Teresina: Fundação Cultural Monsenhor Chaves, 1998.

FERRETTI, Mundicarmo. Pajelança e cultos afro brasileiros em terreiros maranhenses. Revista Pós Ciências Sociais. São Luis: UFMA, v. 8, n. 16, jul.-dez. de 2011. p. 91-106.

FERRETTI, Mundicarmo. Terecô, a linha do Codó. PRANDI, Reginaldo (org.). Encantaria brasileira: o livro dos mestres, caboclos e encantados. Rio de Janeiro: Pallas, 2011. p. 59-73.

GEERTZ, Clifford. O beliscão do destino. A religião como experiência, sentido, identidade e poder.Nova luz sobre a Antropologia. Rio de Janeiro: Jorge Zahar, 2001. p. 149-165.

KAITEL, Alexandre F. S. Não chuta que é macumba: processos de subjetivação em médiuns desenvolventes na Umbanda. Tese (Doutorado em Ciências da Religião). Belo Horizonte: PUC-Minas, 2019.

LEITE, Fabiano A. Costa. Quem está na terra: o autor do discurso religioso da umbanda. 2018. Tese (Doutorado em Ciências da Religião). Recife: Universidade Católica de Pernambuco, 2018.

LIMA, Sabrina Verônica G. As faces da Umbanda no Piauí: política, festa e crimenalidade (1960-1978). Dissertação (Mestrado em História). Teresina: Universidade Federal do Piauí, 2017

LIMA, Solimar Oliveira (org.) Fiéis da ancestralidade: comunidades de terreiros de Teresina. Teresina: EDUFPI, 2014.

MONTERO, Paula. Religiões e dilemas da sociedade brasileira. MICELI, Sergio (org.). O que ler na ciência social brasileira. São Paulo: Sumaré; Brasília: ANPOCS/Capes, 1999. v. 1. p. 327-367.

NEGRÃO, Lísias Nogueira. Umbanda: entre a cruz e a encruzilhada.Tempo Social. São Paulo: USP, v. 5, n. 1-2, 1993. p. 113-122.

NEGRÃO, Lísias Nogueira; CONCONE, Maria Helena Villas Boas. Umbanda: da 
repressão a cooptação. O envolvimento político-partidário da umbanda paulista nas eleições de 1982. Cadernos ISER. Rio de Janeiro: ISER, n. 18, 1985. p. 43-79.

NOGUEIRA, Luara Laíde Furtado; ESPINDOLA, Giovana; CARNEIRO, Eduilson Lí-vio Neves da Costa. Análise da ocupação urbana na Zona Centro-Norte de Teresi-na: considerações sobre a região do encontro dos rios. Revista Equador. Teresina: UFPI, v. 5, n. 3, 2016.p. 25-42.

ORTIZ, Renato. A Morte branca do feiticeiro negro. $2^{\circ}$ ed. São Paulo: Brasiliense, 1999.

PRANDI, Reginaldo. As religiões negras do Brasil. Para uma sociologia dos cultos afro-brasileiros. Revista USP. São Paulo: USP, n. 28, 1996. p. 64-83.

SILVA, Mairton Celestino. Batuque na Rua dos Negros: cultura e polícia na Teresi-na da segunda metade do século XIX. 2008. Dissertação (Mestrado em História Social). Salvador: Universidade Federal da Bahia, 2008.

SILVA, Vagner Gonçalves da. Candomblé e Umbanda:caminhos da devoção brasileira. $5^{\circ}$ ed. São Paulo: Selo Negro, 2005.

SOUSA, Talyta Marjorie Lira. Filhos do Sol do Equador: as vivências e experiências cotidianas de trabalhadores negros na sociedade teresinense no final do século XIX. Dissertação (Mestrado em História). Teresina: Universidade Federal do Piauí, 2012.

SOUZA, Robério Américo do Carmo. De Oxum para Iemanjá: experiências de filhos e filhas de santo em Teresina no século XX - percepções iniciais de uma pesquisa em andamento. Simpósio da Associação Brasileira de História das Religiões, 13. São Luís, 2012.Anais... São Luís: UFMA, 2012.

TERESINA. Prefeitura Municipal de Teresina. Teresina: PMT, 2019. Disponivel em: https://pmt.pi.gov.br/teresina/. Acesso em: 4 ago. 2021.

VIEIRA, Carla Iamara de Passos; SILVA, Tereza Cristina Ferreira. Análises dos impactos ambientais no Parque Ambiental Encontro dos Rios em Teresina - PI.IV Congresso de Pesquisa e Inovação da Rede Norte Nordeste de Educação Tecnológica. 2009. Teresina, Disponível em: http://www.geomorfologia.ufv.br/simposio/simposio/trabalhos/trabalhos_compl etos/eixo11/013.pdf . Acesso em: 13/03/2020.

\footnotetext{
${ }^{1}$ Teresina começou a ser povoada no século XVII com Domingos Jorge Velho e um grupo de bandeirantes que estabeleceram uma feitoria e um criatório de gado. Em 1797 foi erguida a Igreja de Nossa Senhora do Amparo, eem 16 de agosto de 1852 a fundação da cidade foi oficializada. Com um projeto de criação inovador, elaborado por José Antônio Saraiva, Teresina tornou-se a capital da província por sua localização mais central, bem como pela navegabilidade dos dois rios que a cortam, Poti e Parnaíba, que ajudariam no comércio de produtos com as regiões mais próximas. O nome foi uma homenagem à imperatriz Teresa Cristina Maria de BourbonTeresina (2019).
} 
${ }^{2} \mathrm{~A}$ Barra do Poti, por estar localizada em porções de terras próximas à confluência de dois rios, na área de vasão de águas, era constantemente assolada por inundações durante os invernos rigorosos. Assim, em alguns momentos na literatura piauiense/teresinense esta região, onde se concentram os primeiros núcleos de povoação do estado, aparece como um lugar insalubre, sujeito a enchentes e a febres intermitentes e caudalosas, como podemos verificar em Chaves (1998).

${ }^{3}$ Conhecidos por sua bravura e notória habilidade na pesca, esse povo, conforme Chaves (1998), dominou quase totalmente a região da Barra do Poti, resistindo a ataques dos exploradores que invadiam seu território.

${ }^{4}$ De acordo com Silva (2005), os caboclos, além de representarem os espíritos de indígenas que já morreram e voltaram à terra como encantados, neste caso, chamados de "caboclo de pena", dentre outros motivos, porque usam na cabeça um cocar de penas, artefato tipicamente indígena, também são considerados representantes da população multiétnica, proveniente de cruzamentos entre o homem branco e a índia.

$5 \mathrm{O}$ Batuque designou uma dança em que negros e negras, reunidos em círculo, rezavam, cantavam e dançavam em ritmos marcados por palmas e instrumentos de percussão (Sousa, 2012).

${ }^{6}$ Trabalhavam no comércio, na burocracia governamental, eram oficiais de unidades militares; o grupo incluía também advogados e alguns operários especializados. Todos esses indivíduos eram homens e quase todos eram brancos (BROWN, 1985, p. 11).

7 Lopes (2011b, p. 497 apud Bahia, Farlen, 2018, p. 54) salienta que "[...] o omolocô fora um antigo culto provavelmente banto, de origem e práticas obscuras, cuja expansão se verificou no Rio de Janeiro, em especial, na primeira metade do século XX. Desenvolvido principalmente por intermédio da liderança de Tancredo da Silva Pinto, sua difusão foi fruto de uma reação 'reafricanizante" à chamada 'umbanda branca', expandida a partir do Primeiro Congresso de Espiritismo de Umbanda, realizado no Rio de Janeiro em 1941. Reivindicando uma remota origem angolana, no âmbito da cultura dita 'lunda-quioco', o omolocô, já pouco conhecido à época deste texto, parece ter sido apenas uma linha ritual da umbanda, que procurou reviver em parte a antiga cabula".

8José Soares de Albuquerque nasceu em 1939 no interior do Estado de Pernambuco. Fez sua cabeça aos 14 anos na cidade de Santa Bárbara, na Bahia. Chegou em Teresina, em 1956, para estudar e começou a frequentar os terreiros da cidade. Formou-se em 1968 pela Faculdade de Direito do Piauí e, em 1969, se tornou consultor jurídico da Federação Umbandista do Piauí. Foi vereador de Teresina por quatro mandatos consecutivos, a partir de 1970 pelo MDB. Atualmente é desembargador aposentado do Tribunal de Justiça do Piauí. Cf. LIMA, Sabrina Verônica Gonçalves. Ao som do tambor.o processo de institucionalização da Umbanda nas décadas de 1960/70 em Teresina. 2013.Monografia (Graduação em História) - Departamento de História, Universidade Federal do Piauí, Teresina, 2013.

${ }^{9}$ Entre os filhos e filhas de santo de mãe Joaninha do Pontal que fundaram terreiros em Teresina, ajudando a formar uma comunidade umbandista na cidade, destacam-se Pai João Alcântara, com a Tenda Ordem do Silêncio e Pai Aristide Alves Feitosa de Abreu, chefe da Tenda nominada Santa Bárbara. José Bruno de Morais e Joaquim Gomes do Santos, formados pais de santo na Tenda Espírita de Santa Bárbara, edificaram seus templos religiosos no estado vizinho, Maranhão. O primeiro ergueu sua tenda na locali- 
dade chamada Nazaré e o segundo, no lugar conhecido como Cajubeiras (Albuquerque, 1987).

${ }^{10}$ SOUZA, Raimunda Nonata. Entrevista concedida à Ariany Maria Farias de Souza. Teresina, 04 de set. 2019; IANSA, Flavio. Entrevista concedida à Ariany Maria Farias de Souza. Teresina, 12 de mai. 2021.

${ }^{11}$ Luiz Santos é pai de santo há 25 anos da Tenda Espírita Umbandista de Santa Bárbara, localizada no bairro Santa Maria da Codipi, região norte de Teresina.

${ }^{12}$ Encomendada é quando o pai ou mãe de santo instala seu terreiro em um lugar já com seu objetivo traçado.

${ }^{13}$ Sobre Terecô, a linha de Codó, consultar Ferretti (1993; 2001; 2011).

${ }^{14}$ Para mais informações sobre estudos realizados acerca do Tambor de Mina, ver Ferretti (2011).

${ }^{15}$ A Missão de Pesquisas Folclóricas, criada por Mário de Andrade, no Departamento de Cultura de São Paulo, registrou, no ano de 1938, na capital maranhense, o Tambor de Mina, no Terreiro Fé em Deus, de Maximiana, e o Tambor de Crioula, apresentado por um grupo da mesma cidade. A missão percorreu várias cidades do Norte e Nordeste documentando o folclore musical e levando para São Paulo um rico material que seria publicado na forma de livros, vídeos, catálogos, filmes etc. (FERRETTI, 2006).

Recebido em 31/08/2021

Aceito para publicação: 22/09/2021 


\title{
Entre sambas e feitiçarias: a experiência afro-religiosa do xangô em Maceió - AL, no imediato pós-abolição (1889-1900)
}

\author{
Between sambas and sorceries: the afro-religious experience of the xangô in Ma-
} ceió (AL), soon after the abolition ofslavery (1889-1900)

Lilia Rose Ferreira*

https://doi.org/10.29327/256659.12.2-9

Resumo:

As experiências negras e afro-religiosas foram marcadas por uma série de conflitos ao longo da História da escravidão no Brasil. No período pós-abolição, ainda que os sujeitos tivessem maior possibilidade de circulação e de buscar novas formas de liberdade, as querelas envolvendo as práticas sociais, culturais e religiosas dos africanos e seus descendentes permaneceram. Nesse sentido, este trabalho se concentra em analisar as experiências do xangô maceioense, marcadas pelas expressões sagradas, festivas, perseguições e resistências. Para isso, utilizaremos a bibliografia pertinente, e fontes como a legislação e os periódicos da época.

Palavras-chave: Xangô. Maceió. Experiências. Pós-abolição.

\section{Abstract:}

The black and Afro-religious experiences were marked by a series of conflicts throughout the history of slavery in Brazil. In the post-abolition period, even if the subjects had a greater possibility of circulation and seeking new ways of freedom, the disputes involving African social, cultural and religious practices, as well as their descendants', remained. In this sense, this work focuses on analyzing the experiences of the xangô from Maceió city, marked by festive, sacred expressions, persecutions and resistances. For this, we shall use the relevant bibliography, and sources such as legislation and periodicals of the time.

Keywords: Xangô;Maceió; Experiences; Post-abolition.

\section{Introdução}

As religiões negras estiveram, historicamente, na linha de frente das perseguições durante a escravidão no Novo Mundo e no pós-abolição. Esse problema foi investigado, além dos estudos antropológicos do século $\mathrm{XX},{ }^{1}$ também por pesquisadores da história social como João José Reis (2008), e antropólogos que buscaram se voltar aos estudos históricos como Nicolau Parés (2018) e, que

\footnotetext{
"Mestra em História Social da Cultura pela Universidade Federal Rural de Pernambuco, Graduada em História-Licenciatura pela Universidade Estadual de Alagoas, membro do Laboratório Interdisciplinar de Estudo das Religiões (LIER-UFAL) e professora de História da educação básica. E-mail: liliarose943@gmail.com.
} 
trouxeram para o debate o processo histórico com as lutas, resistências e a recriação da experiência religiosa. Bem como a formação de famílias do candomblé.

João Reis (2008) nos assegurou que a religiosidade africana era, além da devoção, uma prática de resistência, um espaço para organizar rebeliões, ajuntar fiéis, rebeldes e festejar. Reis, pesquisando o século XIX, a partir das primeiras décadas, observou que os batuques africanos passaram por um processo de proibição porque as autoridades acreditavam que eram espaços para organizar a revolta escrava. Paralelo a isso, posturas municipais, editais policiais, justificavam a proibição pelo incômodo que os tambores causavam aos moradores de cidades e vilas, além de supostamente mobilizarem comportamentos indecorosos, bebedeiras, desordens e desviar escravos de seus afazeres (REIS, 2008, p. 26). Nosso contexto é do imediato pós-abolição, mas a liberdade nas letras da lei não significou o pleno fim das perseguições, hierarquias sociais e raciais, como ponderou Wlamyra Albuquerque (2009). As tentativas de acomodar a população negra e suas práticas religiosas, permaneceram com outras palavras, não obstante com o sentido similar aquele da escravidão.

Tanto os cultos individuais, quanto aqueles organizados que receberam inicialmente o nome de calundu e que depois ficou amplamente conhecido como candomblé (PARÉS, 2018), sofreram recorrentes investidas de combate e aniquilação com maior intensidade ao longo do século XIX. Esse fenômeno ocorreu em razão do número de africanos livres e libertos, que segundo João Reis, constituíam maioria entre os afro-religiosos, no caso baiano, entre os candomblés. Em Alagoas, Irinéia Santos (2016) apontou para a organização de culto religioso de matriz africana na primeira metade do século XIX, com o mesmo perfil de fundadores semelhante àquele indicado por Reis: homens e mulheres livres e libertos.

Diante do contexto observado, cabe destacar que este trabalho faz parte de uma pesquisa mais ampla. Nosso objetivo foi analisar as experiências negras e afro-religiosas dos africanos e seus descendentes em Maceió, no período de imediato pós-abolição. Desse modo, o resultado da investigação foi a escrita da dissertação de mestrado, defendida em maio de 2021. Dito isso, é importante indicar algumas considerações a respeito das fontes utilizadas, como a exemplo dos periódicos.

\section{O problema das fontes no século XIX e os estudos sobre os praticantes do xangô}


Para estudar as questões pertinentes aos casos dos afro-religiosos, os jornais compõem o principal acervo de fontes, até o presente momento. Os inquéritos policiais para o caso do Xangô Alagoano, têm se apresentado como desafio. A documentação do Arquivo Público do Estado de Alagoas-APA é dispersa e deteriorada. Os relatórios da chefatura de polícia, acessados, quase sempre estavam incompletos. Os jornais quando fizeram menção aos casos policiais anunciaram, muitas vezes, prisões por distúrbios e averiguação, ${ }^{2}$ raras notas descrevem, com precisão, casos relacionados à feitiçaria e afins. Esses dados poucos dizem respeito à problemática, mas são capazes de conjecturar que essas prisões não evoluíam em processos-crime porque tratava-se de uma perseguição que, talvez, fosse até ilegal.

No entanto, voltemos à imprensa que cumpriu papel fundamental na divulgação de notícias sobre prisões, averiguações e levantamento de suspeitas a respeito de comportamentos contrários ao pensamento dominante da época. Desse modo, os periódicos nos auxiliam a compreender as questões no entorno da problemática "sambas e feitiçarias".

Nos anos iniciais da República, as notícias se intensificaram para combater a "incivilidade e os maus costumes". Flávia Pereira (2015) estudou a repressão aos espíritas e candomblecistas na capital baiana do início do século XX, e observou que a imprensa caçava e delatava as práticas e aspirações incompatíveis com os discursos que mobilizavam o ideal de civilização e progresso. Estudando a capoeira em Alagoas, Gustavo Santos (2017) apontou que a repressão às manifestações negras estava presente no Código de Posturas Municipais de Maceió, ainda em 1870 e se intensificou aos fins do século XIX, particularmente no imediato pós-abolição e início da República. Não somente os vadios, capoeiras, ébrios e meretrizes foram perseguidos e criminalizados, os praticantes da magia de matriz africana também estavam na mira do controle social em Maceió. Com a promulgação do Código Penal de 1890, não só os afro-religiosos tiveram suas práticas impressas e penalizadas nesse código, o Espiritismo também foi incluso. Contudo, a perseguição aos espíritas não se deu do mesmo modo em relação aos afro-religiosos, discussão que veremos um pouco mais adiante.

As ideias europeias de progresso e civilização estavam imbrincadas no imaginário da elite desde a primeira metade do século XIX. A chegada da República reforçou a intensidade com que os jornais divulgaram suas aspirações. Os 
jornais O Orbe e Gutenberg, foram principais divulgadores de ideias e intenções de promover uma cidade "civilizada", "limpa", e livre de "crendices" e de qualquer pensa-mento e prática que remetesse ao regime imperial e escravista, como se observou no capítulo anterior.

As "crendices" às quais, muitas vezes, os jornais se referiam, tratavam-se das crenças não cristãs, sobretudo não católicas. As manifestações da fé de matriz africana, por homens e mulheres negros, seguiam como alvos da imprensa com termos e tons irônicos e pejorativos, porque simbolizavam o atraso social, cultural e econômico. Com a ampla divulgação da ideia de progresso e civilização em sincronia com a promulgação do Código Penal de 1890 e o Código de Posturas de Maceió publicado em 1892, a imprensa reforçou, em algumas páginas, as condutas que deveriam ser penalizadas. As expressões da cultura afro-religiosa marcaram muitas destas páginas.

\section{Samba, pagodeiras e as feitiçarias ${ }^{3}$}

Durante a década de 90 do século XIX, o Jornal OCruzeiro do Norte tratou de publicar alguns artigos atentando para as posturas da população. Entre eles, o Artigo 120, que criminalizava os diversos nomes de crenças, especialmente aqueles ligados ao som dos tambores, uso de práticas mágicas, homeopáticas, etc.

De ordem do cidadão dr. Intendente d’deste município, faço público que é terminantemente prohibido pelo Código de Posturas: Artigo 120. É prohibido:

$1^{\circ}$ Fazer bulhar ou vozerias, dar altos gritos à noite, sem necessidade ou utilidade reconhecida

$2^{\circ}$ Fazer sambas ou batuques, quaisquer que sejam as denominações, dentro das ruas da cidade ou das povoações

$3^{\circ}$ Contender ou sustentar controvérsias em altas vozes na rua.

$4^{\circ}$ Tocar tambor, caixa ou qualquer instrumento pelas ruas, ainda que seja com o fim de anunciar espetáculo ou qualquer outro divertimento publico ou particular

Fiscalização do município de Maceió em 6 de outubro de 1892 Hermogenes de Araújo Leite, Fiscal Geral. ${ }^{4}$

Notas referentes a este artigo do Código de Posturas foram publicadas pelo mesmo jornal até dezembro daquele ano. A maior frequência se deu no mês de novembro, ${ }^{5}$ findando as ocorrências em 11 de dezembro.

Este mesmo jornal trouxe informações a respeito dos impostos da intendência municipal. A partir do decreto de 25 de novembro de 1891 o governo aprovou um orçamento para o ano de 1892 que custeava as licenças para bailes, 
pastoris, quilombos, fandangos e reisados. A esse respeito, Irinéia Santos (2016) observou que ali se regulamentava os festejos populares negros no espaço da cidade, no caso do quilombo. Contudo, o mesmo não teria ocorrido com a religião. Os artigos referentes à repressão aos cultos e manifestações afro-religiosas se mantiveram.

Notas sobre a danças, sambas e pagodeiras circularam pelos jornais e a intenção, na maioria das vezes, era de denúncia e exigência para tomada de providência policial. Assim aconteceu em 31 de maio de 1898, quando o jornal $O$ Orbe noticiou a casa do Sr. Félix, onde ocorriam danças todos os sábados até de manhã.

Uma providencia: solicita a tomada de uma providência da parte das autoridades policiais sobre a casa onde habita Sr Felix e o outros no endereço da Rua General Hermes (Cambona), onde ocorrem danças todos os sábados até às 5 horas da manhã. ${ }^{6}$

Essa não foi a única nota que denunciava os divertimentos populares e não por acaso, os locais onde mais se registraram ocorrências dessas ações eram povoações de pessoas empobrecidas e negras.

No jornal Holophote, um comentário em tom irônico ocupou um pequeno espaço na coluna de notas ligeiras chama Secção Electrica em 1897com a seguinte mensagem:

LEVADA, 24 - Neste pitoresco arrabalde pretendem hoje e amanhã festejarem S. João. Realizando-se em diversas casinhas sambas de todas diversidades. Na rua victoria continua o descaramento e consta-nos que haveria ali também o formidável! Samba para maior desfecho. Uh! Uh! A prosa é de venda? Traz cá Lunga. $^{7}$

O bairro da Levada foi construído nos arrabaldes da cidade. Ao desenvolver uma pesquisa de mestrado, a arquiteta Bárbara Nascimento (2008), constatou que ali, se agruparam as populações mais empobrecidas, porque era próximo da cidade e da lagoa. Além da mobilidade pela via fluvial, havia a possibilidade dessas pessoas garantirem a subsistência com as atividades ligadas à pesca. Outro texto publicado nesse mesmo jornal, o Holophote, em 5 de junho, daquele ano, discorria a respeito das festividades de São Pedro e destacava que no quesito de festas e sambas, a "Levada era de ponta". ${ }^{8}$

O "samba", descrito pelo jornal, se revela como uma das manifestações de divertimento da população naquela localidade. A nota, acima, foi escrita com tom 
de desdém, ironia e denúncia, quando se observa as passagens "descaramento", "formidável" e a frase "Uh! Uh! A prosa é de venda? Traz cá". O tratamento por "pitoresco arrabalde" também é capaz de sugerir a ideia de um bairro cujas festividades poderiam ser tratadas como folclóricas por pertencerem às populações ne-gras. Mas ao contrário desse entendimento, Martha Abreu (2018) apontou para o samba e as danças originárias da cultura africana como mecanismo de resistência, além do aspecto do divertimento e da religião, como também eram associados.

A autora observou que as reuniões com batuques eram tratadas como propensas ao crime e colocavam em risco a civilização, no contexto do Império do Brasil. Também, os investimentos das autoridades municipais, provinciais e imperiais, no decorrer do século XIX, não pouparam esforços para proibir os batuques ou qualquer manifestação semelhante, em lugares públicos (ABREU, 2018). Não apenas durante o Império, mas nos primeiros anos da República ao longo do regime provisório, tais práticas eram criminalizadas em Maceió, como bem foi possivel notar no Código de Posturas, no artigo 120, indicava que era proibido fazer sambas ou batuques em qualquer espaço da cidade.

O Código Penal dos Estados Unidos do Brazil, promulgado em 1890, pelo Governo Provisório de Manoel Deodoro da Fonseca em outubro daquela década, semelhante ao Código de Posturas adotado em Maceió, imputava pena criminal conforme o Capitulo XIII, 9 às pessoas que estivessem em ajuntamentos de bandas, maltas ou capoeiras. Vale à pena observar: o Código Penal sofreu uma alteração em 1892, mas só tomou proporção significativa na mudança em 1940,10 quando finalmente, os batuques, capoeiras, sambas, principalmente a capoeira, saiu do referido código e passou a ser entendida como prática desportiva.

Nos agravantes das perseguições e penalidades, estavam as práticas mágico-religiosas da população negra e a relação com as festividades. Para ilustrar que brinquedo popular, lutas sociais e afro-religiosidade estavam intrinsecamente ligados, na noite de 24 de abril de 1904,11 por volta das 2 horas as autoridades policiais foram até uma casa situada no Alto do Jacutinga, de Maria Thereza de Jesus, conhecida como Bico Doce. Ela era uma mulher afamada por ser curandeira, vidente e outras funções ligadas ao cuidado dos espíritos e das pessoas, e também, mestra de Maracatu. 
A nota do jornal A Tribuna sugere que o Maracatu podia ser a solenidade para invocar os espíritos ancestrais, mas também uma festa com maracatu. Ivaldo França Lima (2005) discutindo a respeito dos Maracatus-Nação, nos informou que é complexo indicar uma origem para o surgimento dos maracatus, porque ela possui pontos diversos. Além disso, essa busca, não só torna linear uma história de inúmeros acontecimentos, que necessariamente não foram um acúmulo de fatos em linha reta, "como também oculta e homogeneíza aspectos que são importantes para o entendimento daquilo que se pretende buscar" (Lima, I., 2005 , p. 50). A palavra "maracatu"também indica proximidade étnica com os povos do Congo, um pouco mais precisamente com a festa da Coroação dos Reis do Congo, que acontecia na América Portuguesa, como veremos no próximo capítulo.

Xangô e Maracatu, em Alagoas, parecem ter significações distintas. A primeira ligada ao culto dos ancestrais africanos e a segunda um brinquedo popular. Todavia, aqui, identificamos dois caminhos que se cruzam na encruzilhada das experiências negras na capital: brinquedo popular e afro-religiosidade. Ambos, na mira da perseguição.

Além de Maria Thereza, ligada às práticas mágico-religiosas e ao maracatu, havia mestre Félix. Mestre Félix era um feiticeiro africano, que segundo Abelardo Duarte (1974), era pai de santo de um terreiro em Maceió, pelas imediações do bairro do Jaraguá, no início do século XX. Pela titulação de mestre, é possivel conjecturar que Félix podia ser mestre de maracatu naquela cidade. A relação entre Maracatu e Xangô em Maceió, é capaz de sugerir que os afro-religiosos circulavam entre o universo religioso e o brinquedo popular. Neves Rafael (2004) levantou a questão de que o articulista do jornal, quando noticiou o caso de Maria Thereza, a Bico Doce havia confundido Maracatu com Xangô. É possível que houvesse tal confusão, de modo que a imprensa era um veículo de informação importante, mas que não representava a totalidade dos fatos e das opiniões. Como bem ponderou D’Assunção Barros (2020), quando seguramente analisou, que as fontes históricas são produtos de seu tempo. Pensando nisso, é possível conceber que o jornalista teria se confundido por desconhecimento. Todavia, não se anula a presença de mestres e mestras de maracatu no culto xangô, assim como líderes afro-religiosos do xangô no maracatu, o que nos leva a considerar a relação entre ambos. 
O elemento religioso está ligado no imaginário e no cotidiano de muitos batuqueiros, como vem apontando os dossiês sobre Maracatus Nação (Iphan, 2014). Os instrumentos de percussão dos maracatus se encontram nos terreiros e vice-versa. Assim, observamos quando o jornal A Tribuna publicou uma queixa a respeito dos festejos de Santa Bárbara que ocorriam na rua Barão de Maceió e Dias Cabral, as duas situadas na região central de Maceió. A reclamação era de que os moradores das respectivas ruas.

Charo amigo e Sr. Cel. José Gatto. - Os habitantes das ruas Barão de Maceió e Dias Cabral pedem-nos para que leve ao conhecimento de V. Sa. o desgosto que elles sentem, apezar de serem bons catholicos, de não poderem commungar na mesma taça, com os ardorosos e muito enthusiastas devotos de Santa Bárbara. Os reclamantes têm a allegar não concordarem com o rito dessa egreja, pois as festas que ella promove são abrilhantadas por uma orchestração de adufos, chocalhos e latas que ferem o tympano da humanidade todo um dia e toda uma noite quase freqüentemente. ${ }^{12}$

Não é feito menção ao maracatu explicitamente, nesta nota, e pode estar referindo somente a uma manifestação pública sobre os festejos de Santa Bárbara, que pela forma como é citada, sugere uma celebração à Iansã, deusa africana de origem Iorubá, que foi associada à Santa Bárbara nas dinâmicas de conflito com a Igreja Católica no Novo Mundo. Em Alagoas, Iansã e Xangô, são duas divindades muito presentes nos cultos dos afro-religiosos. Possivelmente, a popularidade de tais divindades teria dado nome aos terreiros conhecidos como casas de xangô (ARAÚJO, 2015).

Os objetos citados na matéria, sobre a festa de Santa Bárbara, se assemelham com os utilizados no maracatu. É viável considerar a relação entre maracatu e xangô, nesse contexto, pensando naquilo que a historiadora Isabel Guillen (2011) argumentou, de que uma nação de maracatu tem "fortes vínculos com uma comunidade de afrodescendentes, relações identitárias com suas religiões e vincula-se fortemente a um sentido de tradição" (GUILLEN, 2011, p. 4).

As informações seguintes contidas, ainda, nessa mesma nota, apontam para reforçar nosso argumento da festa de Santa Bárbara como uma manifestação negra e afro-religiosa, mas travestida de catolicismo popular ${ }^{13}$ ou poderia ser uma prática desse catolicismo. Contudo, o texto sugere a presença da "possessão"14 nos termos que se pode imaginar uma ação mágico-religiosa ao apontar que "o santo, entra quase sempre na cabeça dos crentes e os increos, que são os 
reclamantes, teem de sofrer encommodos pela alta recreação dos devotos."15. Na sequência, a impressão que há é que os devotos de Santa Bárbara que não eram adeptos do modelo religioso com a possessão16, denunciam a prática por se sentirem incomodados, uma vez que, de acordo com os dogmas católicos, as experiências de possessão não são aceitas como práticas religiosas.

Nos embates que seguiram naquele texto no jornal, que foi escrita e publicada por Pedro Nolasco Maciel, o jornalista se posicionou a respeito da "liberdade religiosa". Maciel argumentou que como conhecedor e obediente à Lei, "talvez não fosse de encontro ao preceito constitucional que estabelece a liberdade dos cultos, pois até a Carta Outorgada em 1824, a permitia, sem forma exterior de templo."17 É importante relembrar que Nolasco Maciel era ligado ao movimento abolicionista e adepto dos ideais republicanos (MARTINS, 2012). Contudo, a postura de Maciel, talvez, tivesse outras motivações, já que ser abolicionista e republicano não significava, necessariamente, ser a favor das manifestações da cultura africana e afrodescendente. Alguns republicamos, como o caso de Rui Barbosa, por exemplo, considerava as presenças negras como resquícios do atraso social (CHALHOUB, 1990). Todavia, a nota de Maciel revela: na virada do século $\mathrm{XIX}$ ao XX, as querelas entre a noção de liberdade de culto e perseguição. Nesse sentido, o jornalista continua:

Mas o povo daquellas bandas tem confiança illimitada no tino e
nas maneiras delicadas com que o amigo tem sabido exercer o
cargo. Chegando mesmo um dos mais ladinos da troupe reclaman-
te dar-me lição proveitosa de Direito Público - objectando que os
devotos alteram o socego da maioria. Nada prometi aos que me
deram a honra de fazer a V. S. esta queixa, que o amigo tomará
na consideração merecida. Devo registrar também - e o faço com
particularíssimo interesse de aproveitar o ensejo - que muito es-
peram e confiam os meus constituintes dos bons serviços da acti-
vidade e da energia do digno comissário Sr. Capitão Norberto Bra-
ga, a quem, oportunamente, farei presente o elevado conceito dos
seus concidadãos. Sem outro assumpto, envio a V. As. Com os
meus respeitos, o agradecimento unânime de todos quantos fazem
votos nas ruas Dias Cabral e Barão de Maceió, por sua feliciada
(sic) pessoal (Pedro Nolasco Maciel). ${ }^{18}$

Nos grifos apontados da corrente carta, o autor explicitou o incômodo com as reclamações daqueles que manifestam insatisfação com a festa popular e que, aparentemente, tentam justificá-las por meio da legislação no que se referia à perturbação à ordem pública. Além disso, ao fim da nota, o autor cumprimenta 
os devotos que festejavam nas ruas Dias Cabral (antiga Rua do Reguinho) ${ }^{19}$ e Barão de Maceió em homenagem à Santa Bárbara, demonstrando possivel respeito por eles.

É “Bárbara ou santa?",20 questionou A Tribuna no ano seguinte, em fevereiro de 1904. Tratava-se de mais uma festa promovida por Chico Foguinho em honrarias à Santa Bárbara. A celebração acontecia, novamente, na Rua Dias Ca-bral e suas imediações. A nota seguinte descreve com riqueza de detalhes o acontecimento do dia 04 de fevereiro naquele ano. No referido dia, o repórter foi até à rua e chegando lá, atravessou um arco de flores e folhas até a casa de Chico Foguinho, onde se encontrava uma parte da multidão, carregando uma charola com uma estátua pequena e delicada de uma santa. "Naalgaravia africana dos influentes da tal festa, era a Santa Bárbara". ${ }^{21}$ Finalmente, o repórter entrou na casa e conseguiu falar com Chico Foguinho. Conforme o relato, o pai de santo se apresen-tou descalço, com uma camisa de mangas e disse não ser possivel a entrada, pois o santo (divindade africana), estava em terra, conversando com o mestre Adolpho, pajé baiano. Do lado de fora, o povo se aglomerava em gritos e vivas à Santa Bárbara.

Em meio às animações da festa, o termo "pajé" merece destaque. Este sujeito é entendido como o especialista, curandeiro, sacerdote, santo, mago da tribo, conforme demonstrou a antropóloga francesa Véronique Boyer (1999), ao realizar uma pesquisa de campo sobre a pajelança e presença do caboclo, no contexto de Belém do Pará. Ao tratar da denominação "pajé", é necessário certo cuidado, pois pode possuir significações diversas no complexo cultural, alertou o sociólogo Thiago Santos (2014). Resguardemos então, as assertivas de Nicolau Parés (2011) a respeito do assunto. O autor observou a existência de, pelos menos, três níveis: uma pajelança indígena, uma cabocla - derivada do ritual indígena e com elementos do catolicismo popular ibérico, e a terceira pajelança, mais difundida no caso do Maranhão, especificamente em São Luís, formada a partir da apropriação da pajelança cabocla pelos negros (2011, p. 125). Essa última ocorreu por meio do processo de caboclização ${ }^{22}$ e crioulização, ${ }^{23}$ favorecendo o grande número de convergências existentes entre as tradições tupi-caboclas e as africanas, sobretudo quando se tratou das partilhas de cura e feitiçaria. Contudo, se considerarmos à especificidade do cenário baiano, de onde vem mestre Adolfo, há uma multiplicidade de elementos na composição de alguns terreiros de candomblé. 
Candomblé é uma palavra bantu, ${ }^{24}$ segundo Parés (2005, p. 165) foi a "persistência e recriação de práticas religiosas africanas trazidas para a Bahia pelos escravos, o Candomblé é uma religião de possessão que envolve processos de adivinhação, iniciação, sacrificio, cura e celebração". Entre os candomblés baianos, existiram os chamados "candomblés de caboclo", que segundo Édison Carneiro, era fusão central entre bantus e ameríndios (1991, p. 133). Adolfo era baiano, como já se pôde notar, todavia, é possivel que ele estivesse ligado a esse culto, especialmente, pela indicação da nota a respeito do título de "pajé". Mas, ainda que se considere tal sugestão, não se deve levar a cabo determinados apontamentos feitos pelos jornais porque podem atravessar niveis de chacota e ironia. Anda assim, a presença de um sacerdote baiano sugere que a abolição permitiu, inclusive, a maior circulação de homens e mulheres negros que eram escravizados. Entre eles podiam ter pessoas habilitadas nas questões religiosas de matriz africana.

Chamou nossa atenção, igualmente, o fato de o repórter ter se direcionado ao Chico Foguinho como pai de santo e Adolfo como "pajé". A diferença de tratamento entre os sujeitos nos levou a refletir a respeito do título discutido, haja vista, que pai de santo, é a versão popular de "babalorixá". Segundo João Reis (2006, p. 63), provavelmente o termo deriva do iorubá, babalorixá significava pai de orixá, liderança religiosa masculina.

Após informar ao jornalista que não o receberia naquele exato momento, Chico Foguinho subiu em um banco e discursou provocando a simpatia do grupo $^{25}$. Não se sabe o conteúdo de sua fala, todavia, a ação relatada no período confirma a postura de liderança que o afro-religioso exercia.

\footnotetext{
Depois, a reunião foi dispersando, e o nosso representante pôde entrar no recinto, sendo recebido com zumbaias de adufos e danças macabras, nas quaes uma creola nova fez taes piruetas que abateo-se estafada no solo. Diversas africanas velhas, ornadas de rosários e colares de ouro, acudiram a limpar o rosto da pretinha com alvas toalhas rendadas. ${ }^{26}$
}

As últimas informações do relato demarcaram a presença africana na celebração, com as africanas vestidas de colares de ouro e zelando de uma outra africana, que pela descrição, estava em transe ou possessão religiosa.

"Danças macabras" foi a alcunha atribuída, pelo jornal A Tribuna, à manifestação festiva dos africanos composta de músicas e danças. A denominação 
exposta aparece com frequência nos estudos medievais. De acordo com Juliana Schmitt, estudiosa do imaginário macabro na Idade Média, apontou que uma das aparições das "danças macabras", é na associação com o carnaval. Para ela, a festa carnavalesca era justamente o espaço-tempo da inversão simbólica e os temas macabros são impregnados de inversão. Assim, os mortos retornam à terra e conversam, dançam, riem e se divertem-uma transgressão impossível na realidade tan-givel (SCHMITT, 2017, p. 209). O contexto do surgimento dessas danças é o momen-to de passagem entre o século XIV e o século XV, com a crise do sistema feudal na Europa. Superpopulação, escassez de alimentos, fome, guerra dos cem anos, pes-te, revoltas urbanas, esse é o contexto que produz as danças macabras. A literatura é a sua principal difusora, os mortos apareciam dançando e tocando instrumentos musicais, a inversão é em si mesma, uma sátira: os mortos, animados, aparecem muito mais vivos que seus pares, destacou Schmitt (2017, p. 211). Sem prolongar essa discussão, parece que o repórter, imbuído de imaginação pela literatura europeia sobre as danças macabras, intitulou a manifestação negra como tal.

As contendas que envolviam sambas, celebrações públicas dos religiosos cruzaram a última década do século XIX até o início do XX, como pudemos observar. Entre as notícias que marcam as perseguições, Félix da Costa, se destacou no ano de 1896, como já estamos acompanhando. As notas periódicas possuíam um caráter depreciativo e acusador. Entre elas, de acusações de "feitiçaria”, envenenamento, à imediata prisão do sujeito.

"Basta de Feitiço!", 27 foi a solicitação feita por um leitor, não identificado, ao jornal Gutenberg em 22 de agosto de 1896. O texto, publicado no referido periódico, objetivava denunciar as práticas mágico-religiosas. Segundo a nota, feiticeiros negros tinham a intenção de enfeitiçar a população de Maceió, de modo, a exigir que as autoridades devessem tomar alguma postura contra aqueles sujeitos.

No ano seguinte, com o mesmo engajamento de criminalizar os afroreligiosos, o jornal Holophote, retomou as notícias sobre Félix com um comentário publicado em sua coluna de fofocas cujo objetivo era provocar os leitores (SANTOS. I., 2016). O texto de caráter jocoso estava anunciado com o nome intitulado de "Jaraguá", referente ao bairro onde ocorreu o conflito entre Félix e os carteiros. O autor do comentário assinava por "macaco" e dizia que "enquanto ao tio Felix, o fim de feiticeiro é a detenção". 28 
Esse quadro de perseguições se estendeu para outros grupos sociais e religiosos na capital, mas que tiveram suas experiências e particularidades no tempo e no espaço. A centralidade das questões elencadas até aqui, como a querela envolvendo Félix e os agentes dos correios, nos permitem compreender o cotidiano de lutas, resistências para manter as práticas religiosas diante das criminaliza-ções, em como os sujeitos adotaram as próprias manifestações de fé como armas de defesa.

\section{Conclusão}

Os conflitos enfrentados pelos africanos e seus descendentes no imediato pós-abolição em busca da sociabilidade, de recontextualizar a cidadania e os sentidos da liberdade, foram diversos. Ainda que os sujeitos tivessem maior possibilidade de circulação as atividades envolvendo-os ou promovidas por eles eram alvos constantes, como a exemplo do samba, das manifestações afro-religiosas ou até mesmo o recebimento de pacotes via correio, como aconteceu com o africano mestre Félix.

Desse modo, a partir dos periódicos foi observar como a imprensa não poupou esforços para demonizar as práticas afro-religiosas e corroborar com a disseminação de tal imaginário entre a população. Além disso, a legislação nacional e local respaldavam, no caso do Código Penal de 1890 e o Código de Posturas de Maceió da época, as perseguições contra os sujeitos. Por outro lado, através dessa mesma imprensa, pudemos observar algumas estratégias utilizadas para sobreviver e responder às acusações, como o uso de ameaças e da magia.

Diante das considerações apontadas, cabe ponderar que parte significativa das informações a respeito das negociações e conflitos, bem como as manifestações afro-religiosas em Maceió durante o final do século XIX, estão localizadas nas fontes periódicas. No entanto, mesmo que os documentos policiais referentes aos processos crimes e cíveis, no Arquivo Público do Estado de Alagoas, tenham se relevado de forma diminuta, até o presente momento, é necessário investir mais recursos metodológicos para outros períodos antes e depois da primeira década pós 13 de maio de 1888.

Neste trabalho, objetivamos demonstrar a relevância de aprofundar as discussões e pesquisas a respeito da população negra e afro-religiosa no período de imediato pós-abolição na capital alagoana. Nesse sentido, foi pertinente indicar 
os processos resistências e como a população buscou se firmar e exercer sua liberdade.

\section{Fontes}

Periódicos: Gutenberg, O Orbe, Cruzeiro do Norte, Holophote e A Tribuna.

Legislação: Código Penal dos Estados Unidos do Brasil, 1890 e Código de Posturas Municipais de Maceió, 1893.

\section{Referências bibliográficas}

ABREU, Martha. Canções escravas.Dicionário da Escravidão e Liberdade: 50 textos críticos. SCHWARCZ, Lilia Moritz; GOMES, Flávio dos Santos (org). São Paulo: Companhia das Letras, 2018. p. 130-136.

ALBUQUERQUE, Wlamyra. $O$ jogo da dissimulação: abolição e cidadania negra no Brasil. São Paulo: Companhia das Letras, 2009.

BOYER, Véronique. O pajé e o caboclo: de homem a entidade. Mana. Rio de Janeiro: UFRJ, v.5, n.1, abril de 1999.

ARAÚJO, Clébio Correia de. Alagoas de Xangô.A presença negra em Alagoas. TENÓRIO, Douglas Apratto. Brasília: Senado Federal: Conselho Editorial, 2015.

CHALHOUB, Sidney.Visões da liberdade: uma história das últimas décadas da escravidão na corte. São Paulo: Companhia das Letras, 1990.

DUARTE, Abelardo. Catálogo Ilustrado da Coleção Perseverança. Departamento de assuntos culturais -SENEC. Maceió, 1974.

EVANS-PRITCHARD, Edward Evan. Bruxaria, oráculos e magia entre os azande. Trad. de Eduardo Viveiros de Castro. Rio de Janeiro: Jorge Zahar, 2005.

FEDERICI, Silvia. Calibã e a Bruxa: mulheres, corpo e acumulação primitiva. Trad. do coletivo Sycorax. São Paulo: Disciplinas USP, 2004.

FEDERICI, Silvia. Mulheres e caça às bruxas: da Idade Média aos dias atuais. Trad. de Heci ReginaCandiani. São Paulo: Boitempo, 2019.

GUILLEN, Isabel Cristina Martins. Cultura negra e patrimônio cultural em Pernambuco: o caso dos maracatus nação. Anais do XXVI Simpósio Nacional de História. São Paulo: ANPUH, 2011.

INSTITUTO DO PATRIMÔNIO HISTÓRICO E ARTÍSTICO NACIONAL. INRC do $M a-$ racatu Nação: inventário nacional de referências culturais (Dossiê). 2014. Disponível

em

http://portal.iphan.gov.br/uploads / ckfinder/arquivos/DOSSIE_MARACATU_ NA\%C3\%87\%C3\%830.pdf.Acesso em janeiro de 2021.

LIMA, Ivaldo Marciano de França. Maracatus-nação: ressignificando velhas histórias. Recife: Bagaço, 2005. 
MARTINS, Ana Claudia Aymoré. Solo alagado: uma leitura da cidade em Traços e Troças. ALMEIDA, Sávio de [et. al]. Traços e troças: literatura e mudança social em Alagoas: Estudos em homenagem a Pedro Nolasco Maciel. Maceió: EDUFAL, 2011.

MELLO, Maria Tereza Chaves de. A República Consentida: Cultura Democrática e Científica do Final do Império. Rio de Janeiro: Editora: FGV, 2009.

MOTT, Luiz. Cotidiano e vivência Religiosa: entre a capela e o calundu. SOUZA, Laura de Mello e (org.). História da vida privada no Brasil - cotidiano e vida privada na América portuguesa. Vol. 1. São Paulo: Companhia das Letras. 1997. p. 155-220.

PORTO ALEGRE, Sylvia.Aldeias indigenas e povoamento do Nordeste no final do século XVIII: Aspectos demográficos da" cultura de contato.Ciências Sociais Hoje. São Paulo: Hucitec: ANPOCS, 1993.

PARÉS, Luís Nicolau. A formação do Candomblé: história e ritual da nação jeje na Bahia. $2^{\circ}$ ed. (rev.). Campinas: Editora da Unicamp, 2018.

PARÉS, Luís Nicolau. Apropriações e transformações crioulas da pajelança cabocla no Maranhão.CARVALHO, Maria do Rosário de; REESINK, Edwin; CAVIGNAC, Julie (org.). Negros no mundo dos indios: imagens, reflexos, alteriadades. Natal: EDUFRN, 2011.

REIS, João José. Domingos Sodré, um sacerdote africano: escravidão, liberdade e candomblé na Bahia do século XIX.São Paulo: Companhia das Letras, 2008.

REIS, João José.Sacerdotes, seguidores e clientes no candomblé da Bahia oitocentista.SAIA, Arthur Cesar (org.).Orixás e espiritos: o debate interdisciplinar na pesquisa contemporânea.. Uberlândia: EDUFU, 2006.

SANTOS, Gustavo Bezerra. Uma possivel "simbiose": vadios e capoeiras em Alagoas (1878-1911). Dissertação (mestrado em História). Maceió: Universidade Federal de Alagoas, 2017.

SANTOS, Irinéia Maria Franco dos. A caverna do diabo e outras histórias: ensaios de História Social das Religiões (Alagoas, séculos XIXeXX).Maceió:EDUFAL, 2016.

SANTOS, Irinéia Maria. De quilombos e de xangôs: cultura, religião e religiosidade afrobrasileira em Alagoas (1870-1911).Mneme, Revista de humanidades. Dossiê Religiões Afro-brasileiras. Caicó: UFRN, 2014.

SANTOS, Thiago Lima dos. Pajelança: religião e sociedade no século XIX e XX.Reunião Brasileira de Antropologia, 03 a 06 de agosto de 2014, Natal/RN.

SARTINS, Philippe Delfino. Igreja Católica, a possessão demoníaca e o exorcismo: velhos e novos desafios.Temporalidades -Revista de História. Belo Horizonte: UFMG, 2016.

SCHIMITT, Juliana. A morte vai à festa: das relações entre carnaval e as danas macabras. Revista Abusões. Rio de Janeiro: UERJ, n. 05, v. 05, 2017. 
SILVA, Gian Carlo de Melo. Na cor da pele, o negro: conceitos, regras, compadrio e sociedade escravista na Vila do Recife (1790-1810). Tese (doutorado em História).Recife: Universidade Federal de Pernambuco, 2014.

SLENES, W. Robert. Africanos Centrais. Dicionário da Escravidão e Liberdade: 50 textos críticos. SCHWARCZ, Lilia Moritz; GOMES, Flávio dos Santos (org.). São Paulo: Companhia das Letras, 2018. p. 64-70.

SOUZA, Laura de Mello e. O diabo e a Terra de Santa Cruz: feitiçaria e religiosidade popular no Brasil colonial. São Paulo: Companhia das Letras, 2009.

SWEET, James H. Recriar África: cultura, parentesco e religião no mundo afroportuguês (1441-1770).Lisboa: Edições 70, LDA, 2007.

\begin{abstract}
${ }^{1}$ Alguns exemplos são "A cidade das mulheres" de Ruth Landes (1947); "As religiões africanas no Brasil" de Roger Bastide (1960); "Medo do feitiço: relações entre magia e poder no Brasil" de Yvonne Maggie (1994) e "Xangô Rezado Baixo: Um Estudo da Perseguição aos Terreiros de Alagoas em 1912" de Ulisses Neves Rafael (2004).

${ }^{2}$ Informação encontrada na tabela de averiguações policiais identificadas no jornal Tribuna entre os anos de 1901 a 1912. Fonte concedida por Irinéia Maria Franco dos Santos e Ulisses Neves Rafael. Para os anos entre 1890 e 1899, os dados sobre averiguações policiais, nos jornais alagoanos da Hemeroteca Digital da Biblioteca Nacional, são raros. Identificamos poucos casos, mas que remetem ao espiritismo, como a nota sobre "Dr. Eduardo Silva”, no jornal Gutenberg, em 1899.
\end{abstract}

${ }^{3}$ Os ideais de modernidade e civilização investidos nos anos iniciais da República formaram combustivel potente para popularizar discursos e práticas contra a população afroreligiosa. A historiografia especializada a exemplo dos estudiosos Luiz Mott (2012), Laura de Mello e Souza (1986), James Sweet (2007), apontou que as categorias bruxaria e feitiçaria foram disseminadas pejorativamente quando relacionadas às manifestações religiosas de matrizes africanas, a partir, do contexto da América Portuguesa. Ao longo do processo, parece ter ocorrido uma soma entre os pensamentos e comportamentos da monarquia com os ideais republicanos, quando se tratou da população africana e afrodescendente. O antropólogo Evans-Pritchard (2005), quando estudou o grupo Azande e a feitiçaria, indicou o uso de objetos ritualizados para a obtenção de resultados urgentes como sanar uma doença ou gerar uma mazela, sendo essa uma prática cultural comum para o grupo, livre das ideias católicas europeias. Diante do contexto analisado, cabe problematizar a respeito de termos como "feitiçaria", "curandeirismo" e "bruxaria", isto por que, são conceitos que aparecem com frequência, e na maioria das vezes, de forma demonizada. Nesse sentido, a noção de feitiçaria adotada pelos periódicos é pejorativa, utilizada desde a Idade Média para julgar e condenar pessoas na Inquisição e passou a ser trabalhada no Brasil, durante a escravização e permaneceu no pós-abolição. O epiteto de bruxo ou feiticeiro foi empregado diversas vezes às pessoas escravizadas que resistiam ao regime escravista (Reis, 2003). Silvia Federici refletiu a relação próxima entre as bruxas europeias nos séculos XVI e XVII e a população africana escravizada, comunidades camponesas expropriadas na América Latina e na África e povos indígenas massacrados na América do Norte. A proximidade é que esses grupos vivenciaram a fome produzida pela mudança para agricultura comercial, tiveram suas terras confiscadas e "viram sua resistência ser perseguida como sinal de um pacto diabólico" (Federici, 2019, p. 41).

${ }^{4}$ Cruzeiro do Norte - Maceió, 30 de outubro, 1898. Código de Posturas. 
${ }^{5}$ Mais precisamente ente os dias 8, 11, 13, 18, 20, 23, 27.

${ }^{6} \mathrm{O}$ Orbe - Maceió, 31 de maio, 1898. Uma providencia.

${ }^{7}$ Holophote - Maceió, 28 de junho, 1897.Levada.

${ }^{8}$ Holophote- Maceió, 5 de junho, 1897. Um repórter do Holophote perante os seus queridos leitores.

9 Código Penal dos Estados Unidos do Brasil, 1890. Vadios e capoeiras, Capitulo XIII. Dispo-nivel mhttps: / / legislacao.presidencia.gov.br $/$ atos $/$ ?tipo $=$ DEC\&numero $=847 \& a n o=1890 \& a t o=a$ 2a0TPR5EenpWT4f9

${ }^{10}$ Código Penal, Decreto-Lei $\mathrm{n}^{\circ}$ 2.848, de 07 de dezembro de 1940. Disponível em: http://www.planalto.gov.br/ccivil_03/Decreto-Lei/Del2848.htm

${ }^{11}$ ATribuna - Maceió, 26 de abril, 1904. p. 1. Feiticeiros e feiticeiros.Fonte cedida por Irinéia Maria Franco dos Santos e Ulisses Neves Rafael.

${ }^{12}$ A Tribuna - Maceió, 18 de março, 1903. Rapsódias. Ano VIII, n. 1810, p. 2. [Grifos nossos]

$13 \mathrm{O}$ catolicismo popular se forja nas dinâmicas sociais e culturais entre a população empobrecida, africana, afro-brasileira e indigena, que foi se ressignificando ao longo dos oitocentos (Santos, 2016).

14 Sobre isso, veremos no próximo capítulo, a presença e a possível ascendência do elemento "possessão" nas práticas afro-religiosas.

${ }^{15}$ A Tribuna. Maceió, 18 de março de 1903, p. 2. Rapsódias. [Grifos nossos]

16 Embora, também, existam relatos de "possessão" nos documentos da Igreja Católica, há diferenças singulares e que tornam o fenômeno católico, africano e afro-brasileiro, díspares. No caso católico, quando ocorre a possessão, inicia-se um rito de exorcismo cuja finalidade é expulsar do corpo do sujeito a manifestação demoníaca. Conforme o historiador Philippe Sartin, ao estudar possessões demoníacas e a prática dos exorcismos no catolicismo contemporâneo, essa situação se refere ao demónio quando toma posse de um corpo. Ele faz agir ou falar de acordo com sua vontade, não podendo a vítima resistir e não sendo moralmente responsável por isso. Nesse evento, a questão é estritamente ligada à expulsão do corpo de uma pessoa o espírito indesejado, não convidado e não divino. De modo que, explica Sartin, "expulsão do espírito invasor é o meio através do qual a sua presença é designada,nomeada, assinalada; o cristianismo compreende a tomada do corpo por um espírito na perspectiva implícita de sua expulsão" (Sartin, 2016, p. 451). Ainda segundo o historiador, tal realidade construiu-se ao longo da Idade Média. Já nas religiões africanas e afro-brasileiras, como o Candomblé, a possessão do corpo de um devoto por um espírito ancestral faz parte dos rituais que fundamentam a lógica devocional. Segundo James Sweet (2007), a possessão entre africanos da região Central da África, faziam ritos dessa natureza a fim de realizar consultas para saber a respeito de diversos, como adivinhações relacionadas à saúde, amor, vencer ou não uma guerra, dentre outras informações. O espírito, no caso africano é convidado a estar presente, por meio da "possessão", enquanto no catolicismo, sua chegada não era bem-vinda e devia ser expurgado.

${ }^{17}$ A Tribuna - Maceió, 18 de março de 1903. Rapsódias.

${ }^{18}$ A Tribuna- Maceió, 18\03\1903. Rapsódias. Ano VIII, n. 1810, p. 2. [Grifos nossos] 
${ }^{19}$ Conforme Luiz Otávio Gomes (2012), Dias Cabral foi membro do movimento abolicionista em Alagoas, além de Secretário Perpétuo do Instituto Histórico e Geográfico de Alagoas.

${ }^{20}$ A Tribuna - Maceió, 06 de dezembro de 1904. Bárbara ou santa.

${ }^{21}$ A Tribuna - Maceió, 06 de dezembro de 1904. Bárbara ou santa.

22 Maria Sylvia Porto Alegre (1993), indicou em seu estudo sobre população indígena do Nordeste, um processo chamado de "caboclização": a perda da visibilidade do indígena como categoria étnica que tem "relação direta com a emergência da categoria denominada "caboclo", produto da dinâmica cultural do contato (Porto Alegre, 1993, p. 214).

${ }^{23}$ Para o professor Gian Carlo de Melo, o crioulo é entendido como "uma variável das misturas, não necessariamente é um escravo, ou muito menos um filho de mãe africana já que, estas, geraram vários filhos pardos, o que mostra uma lógica diferenciada das dinâmicas das misturas biológicas" (Silva, 2014, p. 165). Ver a tese de doutorado: Na cor da pele: o negro. Conceitos, Regras, Compadrio e Sociedade Escravista na Vila do Recife (1790-1810).

${ }^{24}$ Quando nos referirmos aos bantus, povos da África Central, utilizaremos a grafia "bantu" e não "banto". Trata-se de atualizar a escrita conforme a nova historiografia da escravidão e da liberdade, a partir de trabalhos como os de Luís Nicolau Parés (2018) e Robert Slenes (2018).

\footnotetext{
${ }^{25}$ A Tribuna - Maceió, 06 de dezembro de 1904. Bárbara ou santa.

${ }^{26}$ A Tribuna- Maceió, 06 de dezembro de 1904. Bárbara ou santa.

${ }^{27}$ Gutenberg - Maceió, 22 de agosto de 1896. Feitiçaria.

${ }^{28}$ Holophote- Maceió, 1892. Jaraguá.
}

Recebido em 31/08/2021

Aceito para publicação em 30/09/2021 


\section{As Comunidades Eclesiais de Base e a recomposição das formas de militância católica no Maranhão (1970-1980)}

The basic ecclesial communities and the reset of Catholic militancy forms in Maranhão (1970-1980)

Wheriston Silva Neris*

https://doi.org/10.29327/256659.12.2-10

Resumo:

O artigo aborda as reconfigurações contemporâneas das formas de militância católica através da análise da criação e evolução das comunidades eclesiais de base na região maranhense. Recorrendo a expedientes metodológicos variados, a análise procura evidenciar duas dimensões interdependentes: por um lado, explora as CEBs como um laboratório de observação sobre os efeitos da promoção do laicato para a emergência de uma nova configuração eclesiástica na região e, por outro, investiga como funcionavam concretamente as redes de apoio católico a movimentos e causas sociais no campo, no seio das quais, inadvertidamente, foi sendo constituída uma ética consubstancialmente religiosa e militante que se encontra disseminada por uma variedade de instâncias e atividades no tempo e espaço maranhense.

Palavras-Chave: Militância; Catolicismo; CEB's; Movimentos sociais.

Abstract:

Thisarticle approaches contemporary reconfigurations of Catholic militancy ways through an analysis of the creation and evolution of basic ecclesial communities in Maranhãostate. Using a variety of methodological expedients, the analysis seeks to highlight two interdependent dimensions: on the one hand, it explores the basic ecclesial communities as a laboratory of observation on the effects of the promotion of the laity for the emergence of a new ecclesiastical configuration in the same state and, on the other hand, it investigates how concretely the networks of Catholic support for social movements and causes in the countryside functioned, within which, inadvertently, a consubstantially religious and militant ethics was being constituted, that is disseminated across a variety of instances and activities in Maranhão's time and space.

Keywords: Militancy; Catholicism; Basic Ecclesial Communities; Social Movements.

\section{Introdução}

A presença recorrente de agentes e organizações vinculados ao catolicismoem modalidades de ação coletiva e em movimentos reivindicatórios no Maranhãoapartirde meados do século passado despertam interesse sobre qual confi-

'Doutor em Sociologia. Professor permanente dos Mestrados em Letras (PPGLB/UFMA) e Sociologia (PPGS/UFMA) da Universidade Federal do Maranhão e docente adjunto do Curso de Ciências Humanas - Sociologia (CHBA/CCEL). E-mail: wheriston.neris@ufma.br 
guração institucional era essa que favoreceu a emergência de uma forma decatolicismo fundada na valorização do engajamento para a "transformação dasrelaçõessociais". Nessa perspectiva, o presente artigo se inscreve em conjunto mais amplo de análises que temos realizado nos últimos anos para compreender as condições histórico-sociais e institucionais que ajudam a explicar como a instituição eclesiástica se tornou lugar de produção de uma relação particular como universo político e social, exercendo o papel de um poderoso apoiador moral e organizacional no âmbito dosmovimentos sociais

Já tivemos a oportunidade de destacar algumas dimensões desse processo de reconfiguração organizacional. A começar pela importância da vinculação cada vez mais intensa da Igreja local a processos e movimentos nacionais e internacionais, ao que se vinculou a emergência de uma pluralidade de estilos sacerdotais e modalidades de militância católica (NERIS; SEIDL, 2015a). Sinteticamente, a combinação entre o processo de segmentação da Arquidiocese de São Luís em diversas circunscrições eclesiásticas, que passaram a ser geridas por ordens religiosas estrangeiras (NERIS, 2014), e a paralela crise de recrutamento sacerdotal observada naqueles mesmos marcos temporais, produziram um corpo religioso marcadamente desnacionalizado (Neris; Seidl, 2015b). Isso favoreceu a vinculação local às problemáticas e modelos de atuação sacerdotais gestados nas redes internacionais (NERIS; SEIDL, 2017). A análise comparativa de diversos itinerários sacerdotais marcados pelo engajamento em causas sociais na região maranhense permitiu então refinar a compreensão sobre as vias de politização religiosa e de conciliação entre disposições sociais, carreiras e formas de militância institucional (NERIS, 2017; NERIS; SEIDL, 2017).

Inscrito nesse esforço para repensar as mutações do espaço católico em âmbito regional, neste texto dedicamos especial atenção à criação de organismos de participação dos leigos correspondentes ao novo lugar que o laicato passou a ocupar naquela configuração institucional. Historicamente, essa promoção se enraíza no crescente reconhecimento dos leigos nas atividades da Igreja desde o pós-guerra, quer por meio da criação e expansão da Ação Católica ao nível internacional, quer pelos movimentos de juventude, obras caritativas, associações confessionais ou pelo engajamento educacional e catequético. No Brasil, e no Maranhão, em particular, a promoção de leigos constituiu uma atividade decisiva para minimizar a fraca cobertura institucional católica. Esta se traduzia tanto pelo diminuto número de circunscrições eclesiásticas quanto pela crise de voca- 
ções. Sob o termo promoção do laicato compreende-se, na realidade, esse "[...] amálgama heteróclito de atividades de ajuda ao clero, de substituição conjuntural do padre e de participação em empresas coletivas de evangelização" (LAGROYE, 2006, p. 207).

Destacam-se entre esses organismos as Comunidades Eclesiais de Base (CEBs). De maneira geral, as CEBs eram agrupamentos de populações pobres pertencentes a uma mesma região e que se reuniam regularmente para ler a bíblia à luz de suas experiências (LESBAUPIN, 1997). Embora existam diversas discussões quanto à extensão numérica dessas comunidades, às suas circunstâncias de nascimento e a natureza comunitária de suas atividades (BURDICK, 1996), como veremos à frente, diversos analistas convergem quanto ao reconhecimento do papel político desempenhado pelas CEBs na medida em que seus praticantes começaram a assumir tarefas sociais e a exprimir reivindicações políticas sobre temas tão variados quanto suas origens: lutas contra discriminação, condições de trabalho, luta contra o agronegócio e a expropriação agrária, acesso à educação e saúde, preservação de culturas locais, etc. (DOIMO, 1992; 1995; KRISCHE; MAINWARING, 2004).

Mesmo quando não contaram com o apoio das hierarquias locais, essas comunidades se multiplicaram rapidamente a partir da década de 1970, inaugurando novas práticas de fé marcadas pela diminuição da distância entre leigos e agentes religiosos, por experiências mais distanciadas dos lugares e formas institucionalizadas de culto e até mesmo fora da mediação clerical imediata (NERIS, 2014).

Em boa medida, tais considerações vão ao encontro das principais teses esboçadas por Sérgio Ricardo Coutinho dos Santos (2015), quanto aos deslocamentos eclesiológicos produzidos pela recepção do Concílio Vaticano II na Igreja maranhense ocorridos em recorte similar ao nosso ${ }^{1}$. Partindo de outras bases teóricas, Santos demonstra de maneira convincente que, a despeito da variabilidade de "tendências dominantes em face do Concílio" no Maranhão (Santos, 2015, p. 221) - correspondentes às modalidades concretas e não unívocas de recepção do Vaticano II nos quadros diocesanos maranhenses - o estudo dos "novos princípios de organização sócio eclesial" no recorte em pauta, permite delinear o surgimento de um novo "ethos católico" e de uma "consciência pósconvencional" de caráter marcadamente reflexivo, verbalizado e comunicativo (Santos. 2015). 
Por nosso turno, já tivemos a oportunidade de explorar em trabalhos recentes alguns dos diversos condicionantes interdependentes que contribuíram para a produção de uma cultura institucional renovada no catolicismo e que participa ainda hoje de sua imagem na região (NERIS, 2014; NERIS, 2017; NERIS, SEIDL, 2017). Embora este artigo se inscreva nesse conjunto de investimentos analíticos anteriores, nosso interesse aqui, no entanto, é problematizar as dinâmicas ocorridas nas fronteiras institucionais e nos polos mais heterodoxos do espaço católico regional para tentar captar com mais clareza a questão mais ampla dos trânsitos de categorias religiosas e politicas nos dois sentidos, a superposição integrada e justaposição de lógicas, bem como as tensões constitutivas das relações entre centro e periferia do catolicismo no Brasil2 (CORADINI, 2012). Daqui deriva, pois, a pertinência da compreensão das CEBs como instâncias decisivas no Maranhão para a criação de redes católicas que forneceram estruturas organizacionais, contatos, recursos, saberes e repertórios de militância para diversos movimentos e causas (NERIS, 2014), como será demonstrado adiante.

É precisamente nesse sentido, aliás que o emprego da noção de militância católica pode ser explicitado. Ela se inspira na Sociologia Política das Instituições (LAGROYE; OFFERLÉ, 2011) e nas diversas pesquisas recentes sobre processos de politização da vida social (LAGROYE, 2003; GALL; OFFERLÉ; PLOUX, 2012; ARNAUD; GUIONNET, 2005; AÏT-AOUDIA et. all, 2011). Essa noção designa um conjunto diverso de iniciativas, estratégias e práticas observadas em vários dominios, duravelmente determinadas, tanto nos seus objetivos, quanto na sua forma, pelo esforço de afirmação da religião como uma maneira de pensar o mundo exigindo (conscientemente ou não) a sua inscrição no espaço de concorrência politica ou mesmo na complementaridade com outras maneiras de definir os problemas e as soluções para o mundo social (RAISON DU CLEZIOUR, 2009).

Nessa perspectiva, o militante católico deve ser entendido como um católico praticante, investido em atividades com alguma significação religiosa, e que atua tanto em atividades internas à Igreja (liturgia, ensino, grupos de leitura bíblica, etc.), reconhecidas como componentes da vida cristã (atividades caritativas, filantrópicas etc.), ou até mesmo em ações, digamos, exteriores à Igreja, mas inspiradas subjetivamente pelos valores religiosos e encorajadas pelo clero (atividades sociais) (LAGROYE, 2006).

Ante o exposto, o objetivo do presente trabalho é analisar as recomposições das formas de militância católica através de um estudo sobre as comunida- 
des eclesiais de base a partir da década de 1960. Metodologicamente, além da realização de entrevistas com lideranças católicas, exploração de relatos memorialísticos, publicações jornalísticas, exploramos publicações de agentes religiosos que participaram ativamente dessas modificações organizacionais (CLEMENS, 1982; MONACO, 2012). Embora se trate de tema sobejamente discutido na bibliografia produzida no Brasil (HEWWIT, 1991; AZEVEDO, 1987; GUIMARÃES, 1978; KADT, 2007, entre outros), no âmbito regional ainda existem poucos trabalhos de relevância que aprofundem a questão em pauta (ADRIANCE, 1996; COSTA, 1994; PEREIRA, 2012a; PORTELA, 2011b; SANTOS, 2015).

\section{As Comunidades Eclesiais de Base no Maranhão}

Ao analisarmos a pluralidade de investimentos católicos no Maranhão ao longo do século XX (Neris, 2014), percebemos que as estratégias de presença institucional da Igreja Católica no espaço rural maranhense e, notadamente, em "questões do campo" intensificaram-se notavelmente com o desenvolvimento das Comunidades Eclesiais de Base (CEBs) na década de 1970 (ADRIANECE, 1996). Apesar de inexistirem estatísticas detalhadas acerca de sua quantidade e tampouco sobre o perfil de seus participantes, sabe-se que em pouco tempo elas não apenas ganharam em organicidade, como também, já na década de 1980, encontravam-se espalhadas pelas "[...] onze dioceses existentes na Província Eclesiástica do Maranhão" (COSTA, 1994, p. 19-20).

De maneira geral, o crescimento acentuado das Comunidades Eclesiais de Base no Maranhão pode ser explicado em função de quatro fatores principais: em primeiro lugar, elas se desenvolveram num período de crescimento da preocupação da Igreja com "problemas sociais" nas décadas de 1960/70, sobretudo com as "questões do campo" (PAIVA, 1985). Além disso, ela também se conectou às modificações ocorridas em movimentos da Ação Católica e seu aumento de importância regionalmente, tanto na capital quanto no interior (ADRIANCE, 1996). Destaca-se, nesse último caso, a criação de núcleos da ACR (Ação Cristã em Meio Rural) em paróquias periféricas da Arquidiocese de São Luís na década de 1960.

Esse movimento foi organizado em várias cidades do Maranhão (Coroatá, Caxias e Santa Rita) através da atuação do Padre francês Jose Servat, que criou diversos desses núcleos no Nordeste ao longo de sua atuação missionária que se estendeu por mais de quarenta anos na região nordeste (SERVAT, 2005; MARIN, 1995). Aliás, além de diversos dos veteranos das CEBs no Maranhão terem se 
originado desses movimentos da Ação Católica (CLEMENS, 1982), as "[..] reuniões da Ação Católica se transformaram nos primeiros encontros das CEBs do Maranhão" (MONACO, 2012, p. 77) . Em terceiro lugar, essas comunidades continuaram a dar ênfase à iniciativa laica na execução de tarefas pastorais (rezas, celebrações semanais, manutenção de antigas tradições populares, pastorais e ministérios específicos), valorizando formas de organização mais horizontais e de tomadas de decisão coletivas em equipes de base relativamente homogêneas. Esse destaque também se mostrou indispensável frente ao aprofundamento da crise de vocações entre as décadas de 1960/80 (NERIS, 2014).

Por fim, o modelo de dinâmica de grupo usado nas CEBs consistia no mesmo método de conscientização desenvolvido no Movimento de Educação de Base (MEB) e na Ação Católica Especializada (ver, julgar e agir) (ADRIANCE, 1996; MONACO, 2012). Assim, antes mesmo que a Teologia da Libertação tomasse as Comunidades Eclesiais de Base como referencial culminante de seu projeto eclesial alternativo, principalmente após a Conferência de Medellín, em 1968, essas comunidades surgiram como herdeiras do conjunto de empreendimentos de "reconquista social" promovidas desde o espaço eclesial naquele recorte.

Vale dizer, porém, que antes de se tornar um movimento com consciência acerca do seu impacto sobre a opinião pública, as CEBs não possuíam de início um plano pastoral preciso e tampouco mantinham vinculações constantes entre si. É assim que, ao pesquisador interessado pelas origens desse fenômeno, elas se apresentam frequentemente sob o signo da variedade (LACROIX, 1974).

Variedade, em primeiro lugar, quanto às fontes e circunstâncias de seu nascimento na região, a partir da década de 1960. Algumas dessas CEBs surgiram simplesmente como comunidades de culto, promovendo celebrações, procissões e a organização tradicional de festejos de padroeiros em capelas rurais (CLEMENS, 1982). Outras nasceram de experiências paroquiais originais, como as desenvolvidas pelos missionários canadenses nas paróquias de Bequimão e Peri-Mirim, inspirados no humanismo cristão e nos métodos da Ação Católica (CARRIER, 2008). Houve também as que resultaram da aplicação de experiências pastorais litúrgicas renovadas, como a missa participada ou o treinamento de pregadores populares, nas paróquias acompanhadas pelo Monsenhor Hélio Maranhão (MONACO, 2012). 
Outras ainda resultaram mais diretamente da tentativa de aplicação das diretrizes do Concílio Vaticano II, como fizeram os padres missionários americanos da Ordem dos Redentoristas na paróquia de São Cristovão, periferia da capital São Luís, a partir de 1967 (ADRIANCE, 1996; PEREIRA, 2012b). Algumas, no entanto, surgiram a partir de conflitos de terra e do desenvolvimento de trabalhos comunitários (CLEMENS, 1982). Não causa surpresa, portanto, que as representações de agentes diretamente vinculados à história desse fenômeno apresentem uma diversidade de pontos de vista quanto às suas condições efetivas de surgimento e, inclusive, a respeito da sua definição (MONACO, 2012).

Assim como as condições de surgimento, a natureza das atividades dessas comunidades era também muito variada, implicando desde a realização de celebrações, o desenvolvimento de atividades caritativas, discussão e resolução de "problemas coletivos", até mesmo a realização de atividades políticas (CLEMENS, 1982). Não havia, portanto, um foco único de atuação, mesmo em se tratando daquelas comunidades que poderiam ser classificadas como mais fortemente engajadas em lutas sociais ou de caráter mais estritamente sacramental. Da mesma forma, as orientações dadas às comunidades poderiam se modificar em função de diversos fatores.

Assim, dependendo de cada diocese, de cada família religiosa, das modalidades de vinculação institucional (diocesano ou regular), das trajetórias e concepções dos agentes pastorais implicados e, até mesmo, das situações vivenciadas por cada comunidade, os investimentos poderiam ser mais estritamente religiosos, políticos ou alternados. Não obstante, como relatou o sacerdote Franco Ausania, o processo de surgimento de lideranças e comunidades tenha sido mais fácil justamente "[...] nas comunidades que dependiam de padres diocesanos e mais dificil onde havia religiosos - Os Missionários Combonianos constituem uma exceção a esta regra" (MONACO, 2012, p. 80) ${ }^{4}$. Mesmo assim as variações eram recorrentes de comunidade a comunidade, e toda alternância de sacerdotes ou de religiosos nem sempre significava a continuidade do mesmo padrão e estilo de trabalho desenvolvido.

Por outro lado, embora tenha se cristalizado a ideia de uma espécie de surgimento espontâneo entre leigos e nas bases populares, agentes de pastoral (principalmente padres e irmãs) exerceram função decisiva e praticamente indispensável para a criação e orientação da maior parte dessas comunidades. De fato, em praticamente todos os principais trabalhos disponiveis sobre o tema no 
Maranhão, os agentes de pastoral foram regularmente considerados como elementos fundamentais no desenvolvimento de Comunidades Eclesiais de Base. Carolina Clemens (1982, p. 76), por exemplo, afirmava que

[...] se é verdade que as bases tinham razão ao reclamar 'falta de apoio', não é menos verdade que o apoio dado por muito agentes de pastoral teve grande peso na história das CEBs. Não eram tão pequenas as fileiras de leigos, religiosas e padres que se dedicaram às CEBs.

Em pesquisa sobre o surgimento das CEBs em quinze paróquias distribuídas entre Pará, Maranhão e Tocantins, Madeleine Adriance (1996) constatou, por seu turno, que entre os fundadores de comunidades era forte a presença de agentes de classe média (religiosas, padres e agentes pastorais). Mesmo no caso de leigos que deram início a outras comunidades, frequentemente se tratava de individuos que já tinham experiências em outras comunidades fundadas por religiosos, ou aqueles ex-militantes da Ação Católica, como ocorreu na cidade de Santa Rita (ADRIANCE, 1996). Nas palavras de um dos ex-coordenadores das CEBs da Arquidiocese de São Luís:

As CEBs foram criticadas pela autonomia e por um suposto anticlericalismo. Mas nunca houve nada contra o clero nas CEBs. Para as CEBs os padres são importantíssimos. O que as CEBs rejeitam não são os padres, mas a postura clerical deles. Quando o padre é respeitoso, quando ele é comprometido, as CEBs o reconhecem e apreciam (MONACO, 2012, p. 122-123) ${ }^{5}$.

O fato de que padres e freiras detivessem maior influência que os bispos para a geração de Comunidades Eclesiais de Base no espaço rural maranhense (ADRIANCE, 1996, p. 189) se devia às próprias características dessas comunidades. Essas eram marcadas pela dispersão em pontos geográficos afastados, cujo contato com a Igreja era realizado quase que exclusivamente por meio dessa camada intermediária da configuração eclesiástica. Tal camada era composta tanto por um conjunto de sacerdotes itinerantes que passavam uma vez por mês, ou a cada seis meses, para fazer as desobrigas ${ }^{6}$, quanto por diversas religiosas que organizavam e incitavam cotidianamente as comunidades para as novas linhas de atuação pastoral. Numa situação em que a atividade sacerdotal assumia feições muito próximas daquelas de um bispo, a oposição aberta de um desses clérigos, esta sim, tinha condições de se tornar um obstáculo dificilmente superável para a constituição de uma comunidade (Adriance, 1996). 
Contudo, ainda que a presença desses agentes religiosos significasse maior vinculação institucional, essa integração esteve longe de representar um controle absoluto por parte do clero. Uma vez organizados os primeiros núcleos das comunidades - através das visitas esporádicas para fornecimento de sacramentos (desobrigas) -, essas CEBs afastadas tinham de se desenvolver de forma praticamente autônoma em relação aos agentes pastorais e, sobretudo, em relação ao episcopado. Ou seja, embora se tratasse sempre de estruturas organizacionais vinculadas à Igreja e que gozavam de apoio e legitimidade institucionais, as CEBs nunca constituíram uma modalidade de influência direta e estrita pela instituição (ADRIANCE, 1996). Dessa forma, suas lógicas organizacionais estavam sujeitas a variações diversas em função das próprias condições de apropriação e de retradução práticas dessas experiências e das relações de interdependência constituídas entre os seus membros. Cabe ressaltar, por outro lado, que não necessariamente isso implicou um questionamento da autoridade clerical. Em diversos casos, na realidade, esta tendeu a ser ainda mais reforçada quando ocorria afinidade entre padres e lideranças laicas em projetos de intervenção social.

Dificilmente essa diminuição da distância entre leigos e padres ocorreria sem que uma diversidade de fatores tivesse promovido uma modificação do papel e do lugar do sacerdote dentro da lógica comunitária e a valorização de novas competências sacerdotais ligadas à gestão e supervisão de equipes de leigos. Um dos movimentos que contribuiu fortemente para isso foi o chamado Movimento Litúrgico que, desde meados do século XX, desafiou a tradição e o regime disciplinar dentro da Igreja brasileira (SERBIN, 2008).

Entre outros aspectos, o movimento preconizava o uso litúrgico da língua vernacular nas celebrações, permitindo tanto a maior participação de leigos quanto a sua aproximação com os padres. No Maranhão, as primeiras experiências pastorais litúrgicas renovadas, com a introdução do livro e da missa participada, foram promovidas pelo Monsenhor Helio Maranhão que, por essa razão, considera-se o principal iniciador das CEBs no Maranhão e no Brasil. E, de fato, antes da implementação desse movimento, como afirmou esse outro sacerdote: “[...] os padres, naquela época, iam para o interior e ainda celebravam em latim. Batizavam e não evangelizavam. Isso era insuportável. Nós começamos a refletir a partir dos fatos da vida. Tudo mudou com o golpe militar de 1964. Aí que as CEBs pegaram mesmo" (MONACO, 2012, p. 77)7. 
Em consonância com a busca de novas formas de atuação clerical no mundo, outro aspecto importante para essa mutação foi a adoção de metodologias e modelos organizacionais, de acordo com as diretrizes emanadas do Concílio Vaticano II e de Medellín, e já testadas em movimentos anteriores (MEB, Ação Católica), as quais enfatizavam a iniciativa laica e a busca por uma ministerialidade decidida pela própria comunidade.

Decisivo, nesse sentido, foi o protagonismo assumido pelo episcopado quanto à adoção do Plano de Pastoral de Conjunto (PPC), entre 1966-1970, e das Diretrizes Gerais da Ação Pastoral (entre 1975-1979), os quais foram importantes para reforço das "estruturas de mediação" e para fortalecimento dos "princípios de organização eclesial baseados na colegialidade episcopal e, posteriormente, em uma sinodalidade de base" - uma das teses principais de Sérgio Ricardo Coutinho dos Santos (2015, p. 163).

$\mathrm{E}$, de fato, isso representou efetivamente uma verdadeira ruptura histórica em relação ao estilo sacerdotal tridentino fundado sobre a separação entre padres e leigos, a neutralização de influência social, a multiplicação dos sinais de pertencimento e as formas convencionais e legítimas de atuação religiosa na região (NERIS, 2014). Essa aproximação não significava, porém, uma atenuação das distâncias sociais e culturais entre agentes pastorais e leigos, o que poderia dar lugar também a uma diversidade de formas de animação pastoral paradoxal, como a que relatou um dos ex-coordenadores das CEBs na provincia.

Constituem elementos positivos das CEBs a ministerialidade nova e protagonismo dos leigos. Claro que esse protagonismo, às vezes, se expressou mal, mas isso é outra questão. É evidente que não faltaram pecados na caminhada, mas são os pecados dos pobres: às vezes o animador agia de maneira autoritária. Seria dificil ser diferente, porque os modelos de gestão do poder que os pobres sempre reconheceram são de tipo autoritário, e eles são induzidos a reproduzir estes modelos (MONACO, 2012, 2012, p. 113) ${ }^{8}$.

Ao longo das décadas de 1970/80, esse movimento das Comunidades Eclesiais de Base conheceu, no entanto, importantes modificações ideológicas e organizacionais no Maranhão. As mutações se conectaram, em primeiro lugar, à própria renovação pastoral provocada pelo Concílio Vaticano II e chamada "opção pelos pobres", expressa em Medellín em 1968 e reafirmada em Puebla, em 1979, bem como a emergência da Teologia da Libertação, que provocaram uma verdadeira ruptura na Igreja em nível continental (COMPAGNON, 2000). De fato, além 
da publicação de numerosos documentos na linha de Medellin e Puebla emanando da Conferência Nacional, das conferências regionais, como as do Nordeste e do Centro-Oeste ou de diversos bispos ${ }^{9}$, a título pessoal, vários padres e leigos se engajaram na tentativa de tornar aquelas equipes de evangelização em meio popular instrumentos de defesa da dignidade dos humildes (camponeses, indígenas, negros, trabalhadores, marginais, prostituídos...) frente ao poder político e os segmentos favorecidos; fossem eles políticos profissionais, proprietários de grandes dominios de terra, empresas multinacionais etc. (NERIS, 2014).

Além disso, o esforço de implantação da "Igreja dos Pobres" na região também contou com o reforço vindo de diversos religiosos estrangeiros (seculares e regulares) que há pouco tinham chegado à região para se colocar a serviço das Igrejas locais, e que eram mais atentos às novas tendências e orientações surgidas na Igreja latino-americana (NERIS; SEIDL, 2015a). A emergência da Teologia da Libertação como matriz teológica e ideológica importante e a promoção das Comunidades Eclesiais de Base como espaços de politização social serviram então para a construção de um poderoso esquema interpretativo capaz de localizar, identificar, etiquetar acontecimentos e mobilizar princípios gerais como "participação", "respeito", "justiça", "o povo" em favor de mobilizações coletivas em todo o Brasil.

Do ponto de vista organizacional, por outro lado, destaca-se o adensamento das conexões entre as CEBs dentro e fora do Estado, notadamente com a organização de encontros provinciais e a formação da equipe de coordenação provincial (CLEMENS, 1982; COSTA, 1994). Quanto a isso, desde o início da década de 1960 já era sentida a necessidade de criação de pastorais mais organizadas nas dioceses do estado, o que fez com que em algumas circunscrições se tomasse a "[...] iniciativa de realizar anualmente a Assembleia diocesana de pastoral, reunindo leigos, religiosos e padres" (ASSELIN, 2009, p. 2).

Quanto às Comunidades de Base, no entanto, os primeiros encontros realizados na região ocorreram na Arquidiocese de São Luís, em 1968, contando com lideranças de paróquias periféricas da capital (Tirirical) e comunidades que hoje fazem parte do território das dioceses de Brejo e Coroatá (ASSELIN, 2009). Esses encontros foram sendo realizados anualmente em São Luís até o ano de 1973, quando foi organizada uma grande reunião de Comunidades contando com a participação de leigos e de agentes pastorais de diversas regiões (Clemens, 1984). 
Entre os agentes que assumiram a frente desse processo de integração regional estava o padre e advogado canadense Victor Asselin que, em 1973, fora designado pelo Arcebispo Dom Motta para ser o coordenador em tempo integral das comunidades situadas no território da Arquidiocese. A respeito desse primeiro grande encontro de 1973, Asselin destacava que uma das principais conclusões foi a identificação da "[...] falta de uma visão mais conflitiva do evangelho [...]", o que impunha "[..] a necessidade da articulação dos agentes e das bases e a importância da análise mais profunda da realidade [..]” (ASSELIN, 2009, p.3). Após esse encontro, pela primeira vez, era possivel ter uma visão sobre a heterogeneidade dessas comunidades, bem como sobre a desigualdade dos níveis de "consciência", organização e capacidade de ação.

Desde então, entrou em curso um efetivo processo de institucionalização das Comunidades Eclesiais de Base que se traduziu tanto pela tentativa de conformação das práticas e representações dentro desse conjunto, quanto pela criação de uma estrutura de coordenação em nível regional capaz de responder aos desafios da nova arquitetura organizacional criada. Tendo iniciado no ano de 1974, o encontro anual da Arquidiocese passou a ser realizado semestralmente (julho/dezembro), contando com a participação de lideranças de todas as dioceses do Estado (ASSELIN, 2009). Da mesma forma, lideranças que estiveram à frente desse processo de integração estadual participaram de encontros visando à articulação em âmbito nacional - a exemplo daquele ocorrido em Salvador, Bahia, em 1974 - e também no nível do regional Nordeste III [composto pelo Maranhão, Piauí e Ceará (MAPICE), conforme a divisão eclesiástica da CNBB], a partir do encontro em Meruoca, no Ceará, onde ocorreu a decisão de criação de uma "[...] equipe regional de articulação, que se deu como tarefa o acompanhamento e a animação dos participantes da região MAPICE” (ASSELIN, 2009, p. 4).

Concomitantemente a esses encontros, começaram a ser articuladas reuniões entre agentes de pastoral que trabalhavam no território definido como Amazônia Legal para estudar a questão da terra (ASSELIN, 2002, p. 62-65). Cabe ressaltar, ainda, que nesse processo de transição organizacional, agentes religiosos estrangeiros desempenharam papeis de destaque tanto à frente dos cargos de coordenação ${ }^{10}$, quanto nos espaços mais periféricos das Igrejas locais. Era sem dúvida a isso que se referia o bispo auxiliar emérito de São Luís, Dom Geraldo Dantas de Andrade, quando afirmava que "as CEBs surgiram, sobretudo, pela coragem dos padres estrangeiros". E continuava: "Eu tenho muita admiração 
pela coragem profética deles. Recebemos muitos padres de fora. Isso foi uma graça para a Igreja, no Brasil e no Maranhão" (MONACO, 2012, p. 75). ${ }^{11}$

Por outro lado, foi elaborada uma espécie de plano de capacitação que envolvia desde o treinamento de lideranças em municípios do interior até a discussão cada vez mais sistemática, ao longo dos encontros provinciais, de temas que incluíam mais diretamente questões relativas à política e aos direitos humanos, direitos do trabalhador, lei da renda, direitos e deveres do lavrador etc. (Asselin, 2002). Sobretudo a partir de 1975, quando os encontros passaram a reunir de 100 a 120 agentes, em média, a questão da importância da ação política em cada comunidade recorrentemente "voltava ao palco" (CLEMENS, 1982). Foi assim que, durante os decênios de 1970/80, as Comunidades Eclesiais de Base se tornaram gradativamente um dos lugares de redefinição das relações com o "social" e o "político" no Maranhão.

A passagem desse conjunto de experiências comunitárias e religiosas diversas para uma estrutura organizacional cada vez mais orgânica exigiu, por seu turno, certa profissionalização das atividades de coordenação e assessoramento às comunidades rurais. Não surpreende, portanto, que a ideia de criação de uma equipe de coordenação provincial das CEBs tenha sido acompanhada justamente pela proposta de fundação da Comissão Pastoral da Terra (CPT) na região, em 1976. Como o descreveu Carolina Clemens (1982), foi durante o encontro provincial nesse ano que agentes de pastoral se reuniram para tratar da criação de uma secretaria para as CEBs e também da Comissão Pastoral da Terra (CPT), visando ao assessoramento jurídico das comunidades. Em certo sentido, isso também chegou a ser mesmo uma demanda das próprias comunidades rurais na proporção em que se aprofundavam os conflitos no campo maranhense (Carneiro, 2013).

Por outro lado, como já tivemos a chance de demonstrar, a implantação de uma série de organismos ligados à CNBB e a movimentos extra paroquiais em curso na década de setenta e oitenta foi beneficiada pela capilaridade oferecida pelo fenômeno das comunidades de base no Maranhão e sua articulação nos diferentes niveis (estadual, regional e nacional). Assim, o que entrou em pauta a partir da década de 1970 foi a efetiva constituição de uma rede organizacional católica composta por órgãos e movimentos que exerciam efeitos uns sobre os outros e nos quais militantes católicos, fossem eles sacerdotes ou leigos, podiam se engajar em nome de princípios morais, éticos e religiosos. Inclusive, a existência desses efeitos interdependentes nessa rede pode ser vista através da decisão 
das lideranças regionais das CEBs de que os encontros regionais haviam atingido o seu objetivo, em 1980, na medida em que diversos organismos de atuação pastoral profissionalizada já haviam sido estruturados na região (ASSELIN, 2002).

\section{As Comunidades Eclesiais de Base e as redes de militância católica no Ma- ranhão}

Iniciamos pela conexão das CEBs com as modalidades de militância social no Maranhão para exploração das dimensões apresentadas acima. Com efeito, da mesma forma que diversos estudos sobre os movimentos sociais nos anos $1970 \mathrm{e}$ 1980 demonstraram essa quase ubiquidade dos participantes das CEBs (MAINWARING, 2004; DOIMO, 1992; SCHERER-WARREN, 1993), no Maranhão seus membros estiveram envolvidos em múltiplas mobilizações e grupos de ação nesse recorte, tais como: Clubes de Mães, Movimentos Populares, Sindicatos Rurais, Partidos Políticos, Ocupações e Resistências à expulsão da Terra etc. É assim que se pode compreender essa figura apresentada na ocasião da reunião de 20 anos das CEBs no Maranhão (1982) localizando as comunidades de base no centro do apoio a formas de transformação da sociedade maranhense. Sem a pretensão de esgotar todas essas modalidades de conexão, valeria à pena destacar alguns exemplos concretos desse tipo de vinculação entre CEBs e modalidades de ativismo social no campo maranhense, com base em diversas pesquisas em curso ou já realizadas no contexto em pauta.

Pode-se começar então pela vinculação das CEBs com a mobilização de mulheres, principalmente no espaço rural (ADRIANCE, 1996). Uma das razões dessa vinculação encontrava-se no fato de que o estímulo ao desenvolvimento de lideranças leigas nas Comunidades Eclesiais de Base, sem referência específica ao sexo, influiu diretamente sobre o público feminino, que constituía a maior parte das pessoas atuando nessas comunidades (ANJOS, 2009). Foi o que observou Madeleine Adriance (1996) em pesquisa sobre a participação de mulheres na luta pela terra. Conforme a autora, muito embora as concepções nas CEBs em matéria de familia e moral tendessem a um confinamento das mulheres na condição de mães, essas comunidades contribuíram inadvertidamente para a redefinição da condição feminina devido a pelo menos três fatores principais. Em primeiro lugar, elas favoreceram o rompimento do confinamento feminino no lar, uma vez que a própria dinâmica dessas comunidades exigia a participação em 
cursos e reuniões periódicas, o que, por vezes, exigia deslocamento geográfico intenso entre comunidades.

Em seguida, promoviam uma tomada de consciência por parte dessas mulheres sobre seus direitos e seus papéis na luta pela terra, isto, na medida em que elas se engajavam em encontros e reuniões na comunidade, embora fosse, muitas vezes, fonte de conflitos no espaço. E, de fato, não foram poucos os exemplos concretos de mulheres enfrentando a polícia, pistoleiros ou participando de ocupações de terra ou de manifestações politicas cujos percursos as vinculavam às Comunidades Eclesiais de Base como lideranças ou participantes regulares. Além disso, em terceiro lugar, ao longo dos diversos cursos e treinamentos que foram sendo realizados com homens e mulheres leigos, estes eram expostos a rituais, cânticos e temas concernentes ao papel de ambos os sexos e à influência da mulher na comunidade local. Para tanto, desempenharam importante papel os agentes de pastoral em atuação, notadamente freiras estrangeiras (ADRIANCE, 1996).

O movimento das Quebradeiras de Coco pode ser tomado como um dos exemplos dessa modalidade de articulação entre socialização nas CEBs e militância de mulheres. Como se pode notar nos trabalhos de Viviane Oliveira Barbosa $(2008$; 2013), diversas das lideranças do Movimento de Quebradeiras de Coco Babaçu (MIQCB) eram também representantes da Igreja em seus povoados, constituindo, por vezes, os núcleos centrais das CEBs e dos Clubes de Mães. Assim, frente à inexistência de espaços alternativos para discussão de aspirações e necessidades por essas mulheres na comunidade, progressivamente esses clubes foram se constituindo como espaços de encontro catalisadores de lutas e reivindicações coletivas, capazes, inclusive, de sedimentar sociabilidades em torno da identificação dessas mulheres com sua condição de "mães". Aliás, uma das principais contribuições desse trabalho foi justamente demonstrar que, ao invés de a identidade materna se tornar um obstáculo para a mobilização de mulheres no campo, ela pôde ser um dos aspectos mais importantes a suscitar o engajamento de mulheres em defesa de problemas relativos à própria reprodução do núcleo familiar (BARBOSA, 2013).

Como também o demonstra a pesquisa de Maristela Paula de Andrade (2007), em uma conjuntura na qual as atividades de coleta, quebra e venda do coco foram se constituindo como garantias de alimentação de diversos grupos familiares no campo, o fechamento dos babaçuais e a limitação das zonas de ex- 
trativismo, principalmente a partir da década de 1970, só poderia aparecer como um cerco à economia camponesa e uma ameaça à reprodução desses núcleos familiares. Em defesa de suas famílias e, o que está incluso, de sua condição de mães, como mostra a antropóloga, essas mulheres participaram inclusive de uma espécie de divisão do trabalho de guerra com seus maridos. Isto pôde se visto nos diferentes episódios de embates nos quais as mulheres se colocavam de maneira combativa frente a diversas situações de violência e até mesmo tentativas de expulsão de terras por grileiros.

Nesses e em outros momentos, a atuação da Igreja Católica através de padres e missionários nas Comunidades Eclesiais de Base (CEBs), e de algumas organizações como a Cáritas, fundada em 1956, era fundamental. Por meio de seu apoio, diversos trabalhadores rurais eram poupados de maiores violências, bem como suas mobilizações e denúncias ganhavam em visibilidade (BARBOSA, 2008, p. 270).

Por outro lado, embora lideranças das Comunidades Eclesiais de Base tenham promovido diversas formas de mobilização social fora dos partidos politicos e de sindicatos tradicionais, não deixaram de estabelecer relações de maior ou menor proximidade com instâncias convencionalmente políticas (eleições, partidos, sindicatos). Esse interesse pela política pode ser ilustrado, inclusive, pela sua escolha como tema principal do $11^{\circ}$ encontro, realizado em 1976, quando uma das principais conclusões da reunião foi a necessidade "fazer a comunidade capaz de escolher seus candidatos"; "é escolher e apresentar candidatos da comunidade" (CLEMENS, 1982, p. 102).

De fato, desde que ganharam em organicidade, as CEBs apoiaram ou lançaram candidaturas de diversos agentes pastorais e leigos no Maranhão. Houve candidaturas desde sacerdotes (embora em menor número), como a do Monsenhor Hélio Maranhão, que se lançou a prefeito de Tutóia em 1978, quanto de leigos, a exemplo de José Santana Rodrigues, que após anos na liderança do Sindicato dos Trabalhadores Rurais do municipio de Morros, foi eleito prefeito do mesmo município em 1989, tendo sido assassinado um ano após (ROCHA, 2011; SILVA; ALBUQUERQUE, 2012). Assim, muito embora, como afirmava o sacerdote Franco Ausania, "As CEBs no Maranhão quase nunca elegeram alguém” (MONA$\mathrm{CO}, 2012$, p.122), os exemplos desse tipo de investimento mais direto, através da proposição de candidaturas, não foram raros no espaço regional. 
Por outro lado, embora nas representações de lideranças das CEBs, essas comunidades tenham estabelecido relações óbvias com o Partido dos Trabalhadores (Monaco, 2012), as pesquisas de Borges (2008) e Costa (1994) mostraram mais claramente que tais vinculações eram muito mais difusas e variáveis, a depender tanto do período quanto da configuração espacial, "[...] alusivas às diferenças entre capital e interior do Estado" (BORGES, 2008, p. 75). Oficialmente, não havia uma escolha partidária única, uma vez que diversos dos animadores dessas comunidades estavam mais próximos ora do PCdoB, do PMDB, do PDT e até mesmo do PT, a exemplo dos municípios de Santa Quitéria, Alcântara e Imperatriz no início da década de oitenta (BORGES, 2008). Uma vez que essa relação com a política partidária sempre comportou uma diversidade de posicionamentos, os diferentes tipos de vínculos não deixaram de suscitar lutas internas e animosidades que se mesclavam com diferentes perspectivas acerca das relações entre movimentos confessionais, posicionamentos partidários e concepções sobre o político e o social.

Porém, raras vezes essas rupturas se mostraram de forma tão explícita como quando foram demitidos sumariamente todos os membros da CPT que mantinham alguma vinculação direta com o PT, em 1980 (BORGES, 2008). Além disso, embora parte dos fundadores do PT tenha iniciado seu engajamento em estruturas da Igreja, a contribuição dos setores mais fortemente engajados da Igreja no Maranhão para a constituição desse partido foi apenas indireta, o que privou a esses diferentes partidos o acesso privilegiado à não desprezível rede católica regional (BORGES, 2008).

Agentes das Comunidades Eclesiais de Base e da Comissão Pastoral da Terra também incentivaram a criação de Sindicatos Rurais (ADRIANCE, 1996), num período de crescimento vertiginoso do número de Sindicatos no Brasil e no Maranhão (ALMEIDA, 1981; BORGES, 2008; COSTA, 1994). Como visto, o investimento promovido pela Igreja para a sindicalização rural e o controle do movimento camponês não era propriamente uma novidade na região, visto que era uma das tônicas das iniciativas promovidas na Igreja Católica desde a década de 1960, através do Movimento de Educação de Base (MEB). Porém, tanto a Igreja quanto a conjuntura política já haviam mudado consideravelmente nas décadas de 1970/80.

De um lado, a experiência de repressão entre 1968 e 1978 e o crescimento da violência contra agentes pastorais em todo Brasil ensejaram, dentro da Igreja, 
a adoção de estratégias de contenção e resistência ao regime. Estratégias essas que iam desde a promoção dos Direitos Humanos por parte do episcopado, o engajamento e apoio de agentes religiosos a movimentos populares e sindicatos autônomos, até a construção de uma rede de informações para evitar a repressão contra seus agentes religiosos e leigos perseguidos (SERBIN, 2001). Em São Luís, por exemplo, padres colocaram à disposição de entidades e militantes estudantis espaços físicos para realização de reuniões, assinaturas de jornais de circulação nacional, mimeógrafos e outros (BORGES, 2008). Além disso, foi montado um serviço de informações em todos os níveis da sociedade: foi assim que prostitutas avisaram a Cúria local de que militares se vangloriavam em um bordel da cidade pela tortura do padre José Antônio de Magalhães Monteiro, preso juntamente com o padre francês Xavier de Maupeau, em 1970 (COSTA, 1994; MONTENEGRO, 2010; SANTOS, 2015).

Quanto à conjuntura política, com a desarticulação dos movimentos organizados por camponeses através da repressão oficial, do intervencionismo e da violência, o regime militar impôs uma série de modificações importantes no sindicalismo rural (ALMEIDA, 1981; COSTA, 1994), as quais merecem ser destacadas. Em primeiro lugar, estabeleceu-se um sindicato único para congregar assalariados e pequenos produtores municipais, uniformizando-os nacionalmente através de uma mesma sigla: Sindicato de Trabalhadores Rurais/STR; segundo, com a criação do Programa de Assistência ao Trabalhador Rural (PRORURAL, e mais conhecido como FUNRURAL), em 1971, "[...] os militares impuseram uma forte marca assistencialista aos Sindicatos" (COSTA, 1994, p. 38). Dentro desses parâmetros, na década de 1970, os Sindicatos Rurais multiplicaram-se rapidamente por praticamente a totalidade dos municípios do Maranhão (129 de 130 disponíveis), sendo possivel conectar essa extensão à busca de "[...] aposentadoria, pensões, auxílio-funeral, serviços de saúde" (COSTA, 1994, p. 38-39).

Quanto à atuação da Igreja no campo do sindicalismo rural, pode-se dizer que, sobretudo com as modificações nas CEBs, com o início da atuação de base da Federação de Assistência Social e Educacional (FASE) na região, em 1971 (LUNA, 1984) e também a criação da CPT, em 1975, a concepção do trabalho pastoral desenvolvido pela rede institucional da Igreja não apenas se diferenciou em relação aos anos 1950/60. Também as estratégias de atuação junto ao movimento de trabalhadores rurais se tornaram mais diversificadas, quer em função da conjuntura política estadual, quer pelas próprias características do movimento sindical em cada localidade (COSTA, 1994). Em outras palavras, à diferença 
dos chamados sindicatos de padres (ALMEIDA, 1981), fundados anteriormente para combater o crescimento da "influência do socialismo e do comunismo" nos movimentos camponeses, os sindicatos promovidos por essa rede, a partir de finais da década de 1970, eram mais decisivamente autônomos e engajados na promoção de mobilizações rurais para resistência ou ocupação de terras.

Enquanto em diversos novos municipios, membros de CEBs foram os primeiros a organizar sindicatos rurais, noutros, o desafio para esses agentes era a conquista dos chamados sindicatos pelegos, ou seja, aqueles que seriam manipulados por proprietários de terra ou por interesses clientelísticos (ADRIANCE, 1996). As estratégias empregadas pela Comissão Pastoral da Terra quanto aos Sindicatos não diferiam muito, como se pode ver em Costa (1994). Com a instalação de um escritório da FASE no município de Santa Luzia, em 1973, esse organismo ensejou ainda a articulação de iniciativas com as demais instituições (LUNA, 1984).

Porém, se em alguns momentos ocorreu uma maior articulação entre os organismos vinculados à Igreja (CPT, CEBs e FASE) e destes com organizações de luta dos trabalhadores rurais como a FETAEMA (Federação dos Trabalhadores da Agricultura do Estado do Maranhão, fundada em 1973), a Confederação Nacional dos Trabalhadores na Agricultura (CONTAG) (COSTA, 1994), essas coalizões também se mostraram provisórias em diversas oportunidades. Assim, após um trabalho de mobilização inicial de maneira articulada entre esses órgãos, "[...] houve desarticulação entre FASE, CPT e Sindicato, influenciando na desarticulação do movimento camponês pela terra, já que as cisões internas do sindicato transformam camponeses em adeptos da FASE ou da CPT" (Luna, 1984, p. 88). Da mesma forma, durante a gestão estadual de João Castelo (1979-1982), houve um forte investimento do governo para cooptação de entidades e lideranças de movimentos de trabalhadores no campo e para dividir os agentes e organismos religiosos mais atuantes nesse âmbito e minimizar sua influência, especialmente da CPT (COSTA, 1994). Para tanto, foi criada a Companhia Estadual de Terras (CETER) e foi nomeado para sua presidência um dos fundadores das CEBs no Maranhão, Monsenhor Hélio Maranhão, que gozava de relações pessoais com o senador José Sarney (COSTA, 1994; BORGES, 2008).

A despeito disso, o fato é que houve uma contribuição decisiva de entidades e de agentes ligados à Igreja para a constituição do sindicalismo rural. Assim, durante os anos oitenta era bastante comum que, após a criação de uma 
Comunidade de Base, ocorresse um investimento para a criação ou a tomada de Sindicatos Rurais locais. Foi assim em Morros, onde o Jesuíta Italiano LuiggiMuraro, juntamente com as Irmãs Capuchinhas, deu início às Assembleias Provinciais, para a formação de lideranças nas comunidades, em 1979, e revitalizaram com o apoio dessas lideranças o Sindicato dos Trabalhadores Rurais de Morros (ROCHA, 2011; SILVA; ALBUQUERQUE, 2012). Da mesma forma, após a chegada de três jovens padres italianos no povoado de Arame/Diocese de Grajaú Claudio Zanonni, Luis Pirotta e Jan Zufellato - administrada pelos Capuchinhos Lombardos, a organização das CEBs criou condições organizacionais para a discussão sobre a necessidade de um sindicato (Adriance, 1996). Em um último exemplo citado por Adriance (1996), no Bico do Papagaio, fronteira entre Pará, Tocantins e Maranhão, tanto as comunidades de base, quanto missionárias e missionários estrangeiros (leigos e religiosos) e a CPT favoreceram a fundação de Sindicatos de Trabalhadores Rurais que desempenharam função importante na resistência de posseiros na região.

Porém, esse vínculo entre o Sindicalismo Rural e a atuação de agentes e organismos religiosos também suscitou estratégias de contenção entre os segmentos dominantes, como descrito por Wagner Cabral da Costa (1994). Essas foram desde campanhas nas páginas de periódicos visando à desmoralização de agentes religiosos até a multiplicação de casos de violência contra militantes leigos e sacerdotes, resultando em ameaças de morte, prisões e até mesmo assassinatos. Como em todo o Brasil, bispos começaram a denunciar e condenar a tortura e a violência sofridas tanto por leigos quanto por religiosos, o que fez com que a instituição passasse a ser considerada como um "[...] ninho de subversão [...]" (SERBIN, 2001, p. 107).

Na delegacia de Ordem Politica e Social, por exemplo, há diversos registros de vigilância de clérigos e leigos por parte de autoridades policiais, a exemplo das comemorações quanto ao Tricentenário da Arquidiocese de São Luís, que contou com a presença de Dom Hélder Câmara (Portela, 2011a). Um dos casos mais conhecidos de repressão a religiosos na região foi o acontecimento da prisão dos padres Xavier de Maupeau e José Antônio Monteiro, em agosto de 1973, tendo sido este último barbaramente torturado. Houve também assassinatos de religiosos, a exemplo do ocorrido com Josimo de Morais Tavares (1950-1986), em Imperatriz, quando era então o coordenador da Pastoral da Terra no Bico do Papagaio (LE BRETON; 2000, ALDIGHIERI, 1993; TAVARES, 1986). 


\section{Considerações Finais}

A exploração das recomposições nas formas de militância católica nas Comunidades Eclesiais de Base, como realizada até aqui, parece ser particularmente instrutiva para a compreensão das mutações do espaço católico regional. Na prática, embora as redes de apoio à militância católica apresentassem variações com o passar do tempo em relação à sua densidade e interconectividade, não parece haver dúvidas de que esse conjunto organizacional exerceu papel importante para a politização de segmentos sociais diversos, sobretudo aqueles mais distantes do universo político convencional, fracamente dotados de capital cultural e cujas condições de mobilização seriam improváveis sem esse tipo de apoio organizacional ${ }^{12}$. Ou seja, na medida em que as CEBs oportunizaram a criação de espaços organizacionais colocando indivíduos em estado de copresença, favorecendo a partilha de representações e rotinas comuns, acabaram por funcionar como vetores de identificação coletiva e mobilização num quadro comunitário.

O exame das relações entre as comunidades eclesiais de base, redes católicas e movimentos sociais no Maranhão levanta, por outro lado, alguns desafios analíticos que merecem ser pontuados, à guisa de conclusão. Em primeiro lugar, a questão das relações entre centro e periferia do catolicismo, visto que o caso das CEBs também permite captar algumas tensões, conflitos e ambivalências de uma situação que pode parecer paradoxal à primeira vista. Trata-se aqui da combinação entre, por um lado, um discurso fortemente marcado pela "periferia", pelo "terceiro mundo", ao passo em que a parte decisiva dos seus promotores e difusores são marcados pela circulação internacional e pela posse de capital cultural distintivo (Coradini, 2012; Neris; Seidl, 2015a).

Em segundo lugar, a análise do caso em pauta permite captar como os trânsitos de lógicas entre os domínios religiosos e políticos não se realizam de maneira univoca e tampouco unidirecional. Eles seriam mais bem compreendidos, em nossa perspectiva, por aquilo que Michel de Certeau (1993) chamava de deslocamento de sacramentalidade, ou seja, um movimento no qual agentes com diferentes graus de vinculação à Igreja se sentiram autorizados a tomar concepções cristãs ao seu modo - por vezes, fora de qualquer referência explícita à Igreja - para fundamentar os seus engajamentos sociais e politicos, dotando-os de um valor sacramental. Assim, organizações que não exibiam características nomi- 
nalmente confessionais começavam a servir como autênticas empresas de bens de salvação, na medida em que eram investidas enquanto tais por diversos dos seus participantes.

Por outro lado, empreendimentos confessionais podiam assumir mais abertamente o caráter de investimentos multidimensionais nos quais a dimensão religiosa era apenas uma entre outras áreas de interesse. Nesse sentido, caberia aqui a ressalva feita por JohannaSiméant (2009, p. 101), para outro contexto, alertando que se o caráter não confessional de um organismo não diz nada acerca dos investimentos religiosos de que ele pode ser objeto, da mesma forma "[...] seria ilusório presumir que as obras confessionais permitiriam usos unicamente religiosos aos seus membros". Trata-se aqui, sem dúvidas, de uma instigante problemática acerca das lógicas de agenciamento entre esferas de vida e acerca da própria constituição de uma ética consubstancialmente religiosa e militante, cuja compreensão é decisiva para compreender a notável disseminação de significados indissociavelmente políticos e religiosos a uma variedade de atividades no tempo e no espaço maranhense (NERIS, 2014; REIS, 2008).

\section{Referências bibliográficas}

ADRIANCE, Madeleine. Terra prometida: as comunidades eclesiais de base e os conflitos rurais. São Paulo: Paulinas, 1996.

AÏT-AOUDIA, Myriam (et. al.). Indicateurs et vecteurs de lapolitisationdesindividus: lesvertusheuristiquesducroisementdesregards. Critique internationale, 1 (n. 50),2011.

ALDIGHIERI, Mário. Josimo: a terra, a vida. São Paulo: Ed. Loyola, 1993.

ALMEIDA, Alfredo Wagner Berno de. Autonomia e Mobilização Política dos Camponeses no Maranhão. São Luís: CPT-MA, 1981. 87p.

ANDIROBA, uma luta pela terra. Direção: Jerome Perret. IDIP Films. Filme. 87 $\min$.

ANDRADE, Maristela de Paula. Conflitos agrários e memória de mulheres camponesas. Revista Estudos Feministas. Florianópolis: UFSC, v. 15, 2007.p. 445451.

ANJOS, Gabriele dos. "Mulheres todas santas": participação de mulheres em organizações religiosas e definições de condição feminina em igrejas cristãs no Rio Grande do Sul. Porto Alegre: FEE, 2009. 
ARNAUD, Lionel; GUIONNET, Christine. Lesfrontièresdu politique: enquêtesurlesprocessus de politisation et dedépolitisation. Rennes: PUR, 2005.

ASSELIN, Victor. O rosto camponês da Igreja. POLETO, Ivo; CANUTO, Antônio. Nas pegadas do povo da terra: 25 anos da Comissão Pastoral da Terra. São Paulo: Ed. Loyola, 2002.

ASSELIN, Victor. Igreja e questões político-agrárias no Maranhão. Alterinfos América Latina, 2009. Disponivel em https://alterinfos.org/spip.php?article3707.

BARBOSA, Viviane de Oliveira. Trabalho, Conflitos e Identidades numa Terra de Babaçu. História Social. Campinas: UNICAMP, v. 1, 2008. p. 255-275.

BARBOSA, Viviane de Oliveira.Mulheres do Babaçu: Gênero, Maternalismo e Movimentos Sociais no Maranhão. Tese (Doutorado em História). Niterói: Universidade Federal Fluminense, 2013.

BERAUD, Celine. Le métier de petre: approchesociologique. EditionsOuvrières, Paris, 2006.

BORGES, Arleth Santos. PT Maranhão 1980-1992: origens, organização e governos municipais. São Luís: EDUFMA, 2008.

BRETON, Binka Le. Todos sabiam: a morte anunciada do padre Josimo. São Paulo: Edições Loyola, 2000

BURDICK, John. Procurando Deus no Brasil. Petrópolis Vozes, 1996.

CARNEIRO, Marcelo Domingos Sampaio. Terra, trabalho e poder: conflitos e lutas sociais no Maranhão contemporâneo. São Paulo: Anablume, 2013.

CARRIER, Yves. LettreduBrèsil: l'évolution de la perspective missionaire: relecture de l'expérience de Mgr. GèrardCambron. Louvain-la-neuve: CollectionSillages, 2008.

CLEMENS, Carolina. É bom lembrar: um pedacinho da história das CEBs no Maranhão. São Luís, Equipe Provincial das CEBs, 1989.

CORADINI, O. L. Os usos das ciências humanas e sociais pelo catolicismo e pelo luteranismo e as relações centro/periferia. Revista Pós Ciências Sociais. São Luis: UFMA, v. 9, 2012. p. 67-99.

COSTA, Wagner Cabral da. O rosto rural da Igreja: A atuação da CPT no Maranhão (1976-1981). Monografia (Licenciatura em História). São Luis: Universidade Federal do Maranhão, 1994.

DAGONET, Phillipe. Brèsil: plusieursvoixpour um cri. Paris: CERF, 1980.

DELLA CAVA, Ralph. Religiões transnacionais: Igreja Católica Romana no Brasil e a Igreja Ortodoxa da Rússia. Civitas-Revista de Ciências Sociais. Porto Alegre: PUC-RS, v. 3, n. 1, 2003.

DOIMO, Ana Maria. Igreja e movimentos sociais pós-70 no Brasil. SANCHS, Pierre. Catolicismo: cotidiano e movimentos. Edições Loyola, São Paulo, 1992. 
GALL, Laurent Le; OFFERLÉ, Michel; PLOUX, François. La politique sansenavoirl'air. Rennes: PressesUniversitaires de Rennes, 2012.

GUIMARÃES, Almir. Comunidades Eclesais de Base no Brasil. Petrópolis: Vozes, 1978.

HEWITT, Willian E. Base Christian CommunitiesandSocial Change in Brazil. Lincoln Universityof Nebraska, Press 1991.

KRISCHKE, Paulo; MAINWARING, Scott. Igreja nas bases em tempo de transição 1974-1985. Porto Alegre: L\&PM: CEDEC, 1986.

LACROIX, Bernard. Le discourscommunautaire. Revuefrançaise de science politique. 24 e année, n. 3, 1974. p. 526-558.

LAGROYE, Jacques. La véritédansl'Églisecatholique. Contestations e restauration d'un régime d'autorité. ÉditionsBellin, 2006.

LAGROYE, Jacques; OFFERLÉ, Michel (org.) Sociologie de l'institution. Paris: Belin, 2011.

LESBAUPIN, Yvo. Communautés de base et politique auBrésil / Base CommunitiesandPolitics in Brazil. Archives de sciencessocialesdesreligions. n. 97, 1997. Religionet politique enAmérique Latine/ReligionandPolitics in LatinAmerica p. 33-45.

LUNA, Regina Celi Miranda Reis. A terra era liberta: um estudo da luta dos posseiros pela terra no vale do Pindaré-Maranhão. São Luís: UFMA/Secretaria Educação do Maranhão, 1984.

MAINWARING, Scott. Igreja Católica e Politica no Brasil. São Paulo: Editora Brasiliense, 2004.

MARIN, Richard. Dom Helder Camara, lespuissants et lespauvres. Pour une histoire de l'Églisedespauvresdansle Nordeste brésilien (1955-1985). Paris: LesÉditions de l'Atelier-LesÉditionsOuvrières, 1995

MATHIEU, Lilian. Une mobilisationimprobable: l'occupation de l'église SaintNizier par lesprostituéeslyonnaises. I Revuefrançaise de sociologie. 1999, 40-3. p. 475-499.

MILESI, Vito. Da cidade Grande ao Sertão. Sem fronteiras. Taboão da Serra, 1983.

MONACO, Luigi Lo. As comunidades eclesiais de base (CEBs) nos discursos dos agentes de pastoral do Maranhão (1964-1989): nascimento e "morte" de um movimento social. São Luís: $360^{\circ}$ Graus Gráfica e Editora, 2012.

MONTENEGRO, Antonio Torres. História, Metodologia e Memória. São Paulo: Contexto, 2010.

MONTENEGRO, Antonio Torres.Travessias: padres europeus no Nordeste do Brasil (1950-1990). Recife: CEPE Editora, 2019. p. 109-214. 
NERIS, W. S. Igreja e Missão: religiosos e ação política no Brasil. Tese (Doutorado em Sociologia). São Cristóvão: Programa de Pós-Graduação em Sociologia, Universidade Federal de Sergipe, 2014.

NERIS, W. S. Conversão e reconversão de padres no Maranhão. Revista PósCiências Sociais. São Luís: UFMA, v. 14, n. 28, jul.-dezembro de 2017. p. 263290.

NERIS, W. S.; SEIDL, E. Redes transnacionais católicas e os Padres FideiDonun no Maranhão (1960-1980). História Unisinos. São Leopolodo: UNISINOS, v. 19, 2015a. p. 138-151.

NERIS, W. S.; SEIDL, E.Uma Igreja distante de Roma. Revista Estudos Históricos. Rio de Janeiro: FGV,v. 28, 2015b.p. 129-149.

NERIS, W. S.; SEIDL, E.Crise e recomposição do habitus religioso na periferia do espaço católico. Pro-Posições. Campinas: UNICAMp, v. 28, n. 3, 2017. p. 204241.

PAIVA, Vanilda (dir.). A Igreja moderna no Brasil, Igreja e questão agrária. São Paulo: Loyola, 1985. p. 52-67.

PEREIRA, Jesus Marmanillo. Ver, Julgar, Agir, Rever e Celebrar: Notas sobre a ação católica em São Luís - MA. XIII Simpósio Nacional da ABHR. São Luís, 2012. Religião, Carisma e poder: as formas da vida religiosa no Brasil, 2012a. p. 1-13.

PEREIRA, Jesus Marmanillo. Comunidades Eclesiais de Base e a Luta por Moradia: Educação e participação politica em contexto de precarização. Tomo. UFS, v. 18, 2012b. p. 101/161.

PORTELA, Camila da Silva. A "subversão" católica no Maranhão: uma análise histórica a partir da documentação da DOPS (1972-1986). Monografia (Graduação em História). São Luis: UFMA, 2011a.

PORTELA, Camila da Silva. Comunidades Eclesiais de Base: movimento social católico, caracterísitcas e comportamento no período do Regime Militar no Maranhão. CARREIRO, Gamaliel da Silva; FERRETTI, Sergio Figueiredo, SANTOS, Lyndon de Araújo (org.). Religiões e Religiosidades no Maranhão. São Luís: EDUFMA, 2011b. p. 199-207.

RAISON DU CLEZIOU, Yann. De lacontemplation à lacontestation: socio-histoire de lapolitisationdesdominicains de laProvince de France (1954-1969). IXeme. Congrès de l'associationFrançaise de Science Politique. Toulouse, Septembre, 2007.

ROCHA, Francisco Rogério Araújo. Morros: história e memória de um povo. Morros (MA): Gráfica Santa Clara, 2011.

SANTOS, S. R. C. "Verbalização do Sagrado" em tempos de fronteiras: a recepção do Concílio Vaticano II no Maranhão 1959-1979. Tese (Doutorado em História). Goiânia: UFG, 2015.

SCHERER-WARREN, Ilse. Redes de movimentos sociais. São Paulo: Loyola, 1993. 
SERBIN, Kennet. P. Padres, celibato e conflito social: uma história da Igreja católica no Brasil. Trad. de Laura Teixeira Motta. São Paulo: Companhia das Letras, 2008.

SERVAT, Joseph. Em missionau Nordeste duBrèsil (1964-2002). Paris: Editionsl'Harmattan, 2005.

SILVA, Katyanne Rocha da; ALBUQUERQUE, Luis Eduardo Moraes de. A importância das comunidades eclesiais de base na formação política do povo morruense. Anais dos Simpósios da Associação Brasileira de História das Religiões. São Luís, 2012. v. 13.

SIMÉANT, Johanna. Socialisationcatholique et biens de salutdansquatre ONG humanitairesfrançaises. Le Mouvement social, mai 2009. p. 101-122.

REIS, Eliana Tavares dos. A "arte" da intervenção política: carreiras e destinos de protagonistas que "lutaram contra a ditadura" no Rio Grande do Sul. CORADINI, Odaci Luiz (org.). Estudos de grupos dirigentes no Rio Grande do Sul: algumas considerações recentes. Porto Alegre: Editora da UFRGS, 2008.

TAVARES, Josimo Moraes. Testamento espiritual do padre Josimo. COMISSÃO PASTORAL DA TERRA. Pe. Josimo: a velha violência da nova república. CPT, 1986.

\footnotetext{
${ }^{1}$ Gostaria de registrar aqui um agradecimento ao parecerista da Revista Plura que ressaltou a pertinência do diálogo com a tese de Santos (2015), defendida um ano após a pesquisa que esteve na base deste artigo (Neris, 2014). Na perspectiva deste autor, parece justa a observação de Antônio Torres Montenegro (2019) quanto a relevância de compreender os referidos trabalhos como complementares para compreensão da atuação sociopolítica da Igreja católica no Brasil e particularmente no Nordeste.
}

2 Para uma proposta instigante de discussões nesse âmbito, consultar: Coradini, 2012.

${ }^{3}$ Entrevista com Dom Xavier Gilles De Maupeau realizada em 03.07.2007

${ }^{4}$ Entrevista com Franco Ausania realizada em 14.04.2012

5 Entrevista com Jean Marie Van Dame realizada em 31.06.2007

6 Como esclarece VitoMilesi (1983), a desobriga consiste em um método pastoral préconciliar que se caracteriza pelo deslocamento de padres/religiosos pelos interiores maranhenses, percorrendo vastas extensões territoriais e enormes distâncias da matriz, para uma longa temporada (vinte, trinta ou até quarenta dias seguidos) de prestações de serviços religiosos previamente programados (missas, casamentos, batizados, entre outros).

7 Entrevista com Dom Xavier Gilles de Maupeau realizada em 03.07.2007

8Entrevista com Dom Xavier Gilles de Maupeau realizada em 03.07.2007

${ }^{9}$ A este respeito, consultar também: Santos (2015)

10 Como se pode ver na cronologia das CEBs proposta por Carolina Clemens (1982), além do canadense Victor Asselin, que assumiu a coordenação da Arquidiocese de São Luís em 1973, exerceram funções de direção os franceses Xavier de Maupeau e Jean Marie Van Damme; o bispo italiano Dom Ricardo Páglia e a freira norte americana, Carolina Clemens. 
${ }^{11}$ Entrevista com Dom Geraldo Dantas de Andrade realizada em 22.06.2007

12 Para uma análise particularmente instrutiva a respeito desses processos, noutro contexto, consultar: Mathieu, 1999.

Recebido em 10/10/2021

Aceito para publicação em 14/10/2021 


\title{
A copa do Juazeiro é verde, as raizes são alagoanas
}

\author{
Joazeiro's treetopis green, the roots are from Alagoas
}

Francisco Airton Bastos Silva Filho*

https://doi.org/10.29327/256659.12.2-11

Resumo:

O presente artigo é parte da integra de etnografia realizada entre os anos de $2018-2020$, no município de Juazeiro do Norte, que teve como objeto: etnografar o ritual de peregrinação e visita ao túmulo do Pe. Cícero Romão Batista por um grupo de oito romeiros do estado de Alagoas. Especificamente, o corrente texto, trata da identidade do romeiro, onde tem no de Alagoas, uma das maiores representatividades: histórica, cultural, humana e social. Destaca-se o protagonismo do romeiro, a espontaneidade e autenticidade da cultura romeira no Juazeiro do Norte e a corporalidade do romeiro alagoano em sua performance/ritual como sendo sua marca e característica mais marcantes. O artigo ainda desvela elementos históricos/culturais do catolicismo popular resistentee que se mantém até hoje na cultura do romeiro de Alagoas.

Palavras-chave: Romeiros. Alagoas. Protagonismo. Ritual.

Abstract:

This article is part of ethnographycarried out between 2018-2020, in Juazeiro do Norte city, aiming to do ethnographyon the pilgrimage ritual and visit to the tomb of Father CíceroRomão Batista by a group of eight pilgrims from the state of Alagoas. The current text specifically deals with the identity of the pilgrims, who has in Alagoas one of their greatest historical, cultural, human and social representations. The pilgrims' protagonism stands out, as well asthe spontaneity and authenticity of the pilgrims' culture in Juazeiro do Norte, not to mentionthepilgrims' corporality from Alagoas in his performance/ritual as being his most striking mark and feature. The article also reveals historical/cultural elements of popular Catholicism that are resistant, keeping themselves even nowadays in the pilgrims'culture of Alagoas.

Keywords: Pilgrims; Alagoas; Protagonism; Ritual.

\footnotetext{
"Membro do Conselho Editorial da Editora Olyver. Membro e sócio correspondente da Academia Palmeirense de Letras - Palmeira dos Índios - Alagoas. Membro efetivo do Grupo de Estudo e Pesquisa em Religiosidade Popular Sociedade e Cultura (GPRESC). Licenciatura em História pela Faculdade Campos Elísios - São Paulo, SP. Mestrado em Antropologia Social pelo Instituto de Ciências Sociais da Universidade Federal de Alagoas (2018 - 2020). Membro efetivo do Coletivo de Estudos em Religião e Cura (CuRare). Membro pesquisador do Laboratório de Antropologia Visual de Alagoas - AVAL. E-mail: franciscobastos.36@gmail.com.
} 


\section{O Contexto das Romarias em Juazeiro do Norte}

As romarias no Juazeiro do Norte surgem como movimento social de uma religiosidadepopularmuitopungentefrenteaocatolicismoromanizado,natransiçãodo século XIX para o XX. (GUIMARÃES, 2011), ao citar Jacques (MÂ̂TRE, 1968), reconstrói com seu pensamento histórico esse expediente da religiosidadepopular.

Em sua constatação, o conceito de religião clerical religiosidade popular, tem seu sentido nas sociedades em que autoridades religiosas garantem forte regulamentação da ortodoxiae da ortopraxia.

Essa relação do catolicismo popular alimentada por uma religiosidade também popular e catolicismo romanizado sempre existiu, sobretudo, após uma sexta-feira, de $1^{\circ}$ de março de 1889 em que a hóstia sangra na boca de Maria de Araújo publicamente depois de inúmeras manifestações, segundo (NETO, 2009).Quatromesesdepois, em 7 dejulhodo mesmo ano, no domingo que marcava o ápice da festa cristã do "Precioso Sangue", Juazeiro do Norte recebe os primeiros 3.000 romeiros oriundos do Crato, cerca de dez vezes a população local.

Tem-se, então, o sacerdote acolhedor, conselheiro, o protagonismo e misticismo da beata que reacende o fervor dos movimentos religiosos e os romeiros sacralizando a pertença, formando, assim, as romarias de Juazeiro do Norte. Ainda sobre o catolicismo popular, Guimarães (2011, p. 05) escreve considerando J. Comblin (1968): "O Catolicismo puro não existe. Trata-se de uma visão do espírito e não de uma realidade concreta que se poderia observar".

Entre não "existir" e não poder generalizar, dentro da micro-história da antropologia social, fica mais claro particularizar dentro de uma estrutura aparentemente "homogênea". Em uma perspectiva simbólica, a relação humana e mística/divina com o Pe. Cícero e social dos romeirose o Juazeiro do Norte,é reflexo de uma construção em se tratando do catolicismo popular de Juazeiro, que é feita a partir da imaterialidade e da materialidade,do saber e do fazer doromeiro.

Em tempos contemporâneos, inevitavelmente e de forma dinâmica, sentem-se os efeitos do que se chama de pós-modernidade (HALL, 2006), em que se dá uma maior atenção à micro-história, às diversidades e à subjetividade.

Oliveira (2004, p. 196) filósofo da Universidade FederaldoCeará, escreveu em que é muito complexoo assim chamado "ressurgimento do Sagrado",uma vez 
que o "modelo" de fé foi sem premoldadona perspectiva pré-moderna. Essa perspectiva pode ser analisada pela óptica dos três agentes de StuartHall: o iluminista, o sociológico e o pós-moderno. Penso que essa afirmaçãodeuma "complexidade do ressurgimento do Sagrado"só se sustenta se não se diversifica; se considera-se apenas o sujeito centrado, unificado, eurocêntrico, etnocêntricocomo descreve Hall (2006, p. 10). Sobretudo após 1960 comuma "abertura" da Igreja Católica Apostólica Romana, contudo, o romeiro bem antes, afirma-se com seu protagonismo.

\section{O Romeiro como Ator Cultural - onde está ele, aí está o Padrinho}

Aqui, o sujeito é o romeiro, cidadão do mundo, não isolado, interconectado e atuante, alimentador das romarias e devoto do Pe. Cícero. Revela-me que é protagonista, atuante, dinâmico e deslocado a partir de uma fragmentação do que se pensava até então do conceito de estrutura a partir de mudanças nas paisagens culturais de classe, gênero, sexualidade, etnia, raçaeracionalidade. E por que não acrescentar aqui, nas paisagens religiosas. Hall faz refletir que o romeiro é um su-jeito histórico e cultural acima de qualquer definição ou deslocado por forças fora de si mesmo (HALL, 2006, p. 17).

Interessante notar a observância dessa constância sendo descentrada por "forças fora de si mesma" e como se percebe esse fenômeno é mais histórico/antropológico que sociológico. Posso atribuir essa força exterior ao fenômeno da comunialidade percebida nas romarias, em que o romeiro se alimenta dos elementos simbólicos/místicos/religiosos e, portanto, culturais que, por meio de sua corporalidade, retroalimentam essa força.

Quando faloque este estudo é mais histórico/antropológico que sociológico, estou considerando que, bem mesmo antes de existir a romaria em sua coletividade/comunialidade, há um sentido de ir individual, uma intencionalidade e uma motivação que fazem os agentes das romarias serem os detentores da romaria. O exterior é resultado do que interiormente é projetado na forma "dos passos longos...", "dos benditos", “da visita ao túmulo" entre outros aspectos observados.

Hall (2006, p.11) ainda considera que a "noção de sujeito sociológico refletia a crescente complexidade do mundo moderno e a consciência de que este núcleo interior do sujeito não era autônomo e autossuficiente, mas era formado na relação com "outras pessoas importantes para ele". 


\section{Liminaridade e Communitas}

Para o romeiro, "outras pessoas" são o Pe. Cícero, a beata MariadeAraújo,o beato Zé Lourenço, a beata Bichinha, Roque Pinto e outros que, assim como eles, construíram e constroem a mística do que é Juazeiro doNorte.

Menciono o que está em "Papel passado..." de (LOPES, 2011) "onde o romeiro está, está o santo, e vice-versa". Dentro dessa hagiografia, considero o que escreve KUNZ (2011, p. 11) quando afirma que o padrinho sagrado e o padrinho profano são o mesmo; ele também foiperseguido e oprimido, assim como o romeiro que pede e, ao mesmo tempo dá, se oferece. Claro que nesse contexto, existem "outras pessoas, ou forças", mas o que se trata aqui está além de qualquer força ou hierarquização romanizada, pois está no campo da "simbologia interacional".

Historicamente está registrado que os movimentos religiosos denominados romarias dos romeiros do Pe. Cícero e da "terra da mãe de Deus", ressurgiram hámais de um século, opondo-se às tentativas de extinção do catolicismo popular e à normatização da romanização eurocêntrica. Esse catolicismo inserido na religiosidade popula revidencia o que escreve(HALL, 2006),"sujeitos totalmente descentrados e avessos à ideia de uma unificação normatizada de centralidade impositiva”. Se escrevo de protagonismo antes de depois do século XIX, a ideia de modelo construído, moldado por forças superiores, o que se observa em Juazeiro, é que o contraponto dessas forças, "catolicismo popular" e "catolicismo romanizado" sempre existiu.

Talvez, aqui se tenha uma ideia mais clarificada do conceito de "comunialidade", em que a estrutura religiosa do Juazeiro é formada pelo pluralismo de tradições culturais religiosas diversificadas, mas todas no âmbito do catolicismo, como os "Ave de Jesus"“os devotos de Pedro Batista e Madrinha Dodô", "os romeiros pedintes", além de muito pontual mente se observar também integrantes de religiões de "matrizes africanas e indígenas" pormeiodeumaespontaneidademuitoprópriasdosromeirosqueencontram em juazeiro a liminaridade e sua "Communitas" observada a partir de Tuner (1974) dentro da dimensãoalterizada. 
Complementa Oliveira (2004, p. 197) que "houve uma perda de força da institucionalização da religião" como algo de fora para dentro, e que se observa um movimento inverso, de interiorização de um fenômeno plural e multiforme, como são as romarias em Juazeiro do Norte. Não cabe mais um entendimento teórico,vendo as dinâmicas das romarias atuais, de uma ideia de romaria com "limitações" culturais, religiosas, de formatações fechadas ouisoladas. Hoje,tanto o catolicismo romanizado quanto o catolicismo popular convivem nos mesmos espaços dessa dimensão comum que possibilita a convivência "alter", mesmo que em alguns aspectos, ritualísticos e culturais haja diferenças de olhar e corporalidade entre o espaço construído institucional e a espacialidade do romeiro conceituada por Dumoulin (2018).

Contudo lembro que essas relações durante anos estiveram na dimensão mais "alios" onde era clara a existência de muros muito altos entre esses dois catolicismos, queaideiadeuma“redesocial"nãoerapossivel.Hoje se observam muito mais as pontes de alteridade, do que os muros hegemônicos, normativos e institucionais. A análise do conceito de redes sociais ajuda nesseexpediente.

\section{Redes, Conexões e Interconexões Culturais nas Romarias}

ApartirdasleiturasfeitasdostextosdeBarnes (1987)eHennerz (1997, 2015), Auge (2010), Agier (2015), compreende-se o conceito de rede social. Baseado em meu objeto de estudo, que é etnografar os movimentos religiosos, a peregrinação e a visita ao túmulo de Pe. Cicero, a partir de intenções e motivações que levam esses romeiros de Alagoas a Juazeiro doNorte.

O entendimento do estudo sobre redes sociais é algo que Hennerz (2015, p. 168) vai dizer: "aideia de redes na Antropologia significa abstrair de algum sistema mais amplo, para objetivos analíticos, conjuntos de relacionamentos mais ou menos elaborados". Esse expediente pela complexidade de um estudo dessa natureza, não é meu foco. Trago uma reflexão sobre os autores acima e a ideia pós-moderna de rede socialpara melhor clarificar o entendimento das conexões e interconexões e extra conexõesdas relações em Juazeiro dasromarias.

A ideia de rede social em Juazeiro do Norte baseada na concepçãode Hennerz (2015) pode ser analisada a partir da ideia tecnológica de rede,que está bem expressa nos textos, a rede social de Juazeiro do Norte e seus grupos aqui citados e objetos dapesquisa. 
De forma objetiva, sabemos que a análise da rede social das romarias em Juazeiro do Norte encontra fundamento em Hannerz (2015, p.168), com quem divido a mesma preocupação:

tornou-se necessário ter uma mente mais aberta com relação à delimitação das unidades de estudo, já que, com frequência, não podíamos depender dos limites sociais "naturais". De um lado, até a comunidade local podia ser uma unidade complexa e muito grande para ser analisada, e não necessariamente relevante de um modo geral para otipodeanálisequetínhamosemmente. Por outro lado, não podiamos deixar de considerar as conexões que estavam fora dela, com a região, com a nação, com o resto do mundo.

Sendo as romarias de Juazeiro uma rede social total, mas não homogênea, absorve automaticamente as outras e suas interconexões; duas dessas redes mais dentro da análise, formadas por romeiros e nativos (artesãos, comerciantes, etc.), um pouco mais distante, mas notada nessa rede social, oturista por exemplo,em que socialmente falando, essa totalidade possui um fluxo religioso, cultural, social, econômico, turístico muito intenso e produtivo.

Essaredeto-

tal(Romarias/Juazeiro)éalimentadaprincipalmentepelosromeirose suas redes externas, cidades do Nordeste e que também recebem, nos últimos tempos, fluxos de outras regiões. Segundo D. Gilberto Pestana de Oliveira, Juazeiro, em 2018, recebeu uma leva significativa de romeiros do Rio de Janeiro, São Paulo e Paraná que alimentam as romarias dentro do município cearense e que são grupos de pessoas que enxergam e possuem conexões com o mundo lá fora, mas possuem seus conjuntos de relacionamentosinternos.

Essa relação em redes como interligação, inteiração e fluxo social, demonstrasua capacidade de interligar com maior afinidade seus membros e niveis mais abertos de interconexão, mas nunca são fechados, entre individuos que partilham experiências nos mesmos espaços e participam dos mesmosrituais.

Essas redes que são internas e externas, ao mesmo tempo, pois são dinâmicas e em Juazeiro se aglutina mês e espalham pelo movimento cíclico dasromarias,podemser lidas no grupo dos oito que protagonizam estapesquisa.

Maria Regina, Carminha, Zé Izídio, Maria Rosângela, Nilzete, todos deCoqueiro Seco, D. Luzinete de Joaquim Gomes, D. Zeze e Dalva de Maceió, a Fátima (Fau) de Paripueira, todos com vidas distintas, trabalhos, relações familiares dis- 
tintas, sociais distintas e comuns também entre seus familiares e relações sociais sem qualquer grau de parentesco, em Juazeiro em época de romarias, formam essa grande rede total composta por tantas outras redes e interconexões, fluxos, sempre no movimento de chegadas e partidas. Outros agentes protagonistas que aparecem ou espontaneamente me abordaram durante a etnografia, foram: o Senhor Antônio Ferreira de União dos Palmares; José Maurício, Secretário de Assistência Social de Maribondo; D. Adalgiza de Jesus de Mar Vermelho; Dona Creuza Luiza Lima da Silva de Maribondo, que alimentam essa rede social total alimentam com suas relações e acessamoutras.

Primeiro, a rede dos romeiros, observamos um grupo social que se nutre e retroalimenta a mística de Juazeiro do Norte com seu catolicismo popular, que, por sua vez, está em peregrinação rumo ao túmulo de Pe. Cícero que pode ser vista como a espinha dorsal que canaliza essas redes de pessoas e grupos que surgem de vários lugares. Sentido de uma liminaridade.

Dessas redes internas ou grupos, que têm por função agregar e concentrar todo o fluxo social e, por sua vez, o ritual de partida, peregrinação, visita ao túmulo e retorno às suas origens, podem também ser vistos como mantenedores necessários para a tradição dasromarias. É importante dizer que, nos últimos anos, várias mudanças ressignificam as romarias; contudo é salutar dizer que sua tradição existe e éconservada por várias ações. Uma dessas ações mais evidentes é a existência do Círculo Operário São José que tem à frente a irmã Annette, que executa um trabalho de recepção, acolhimento e preservação da cultura mais tradicional das romarias. Outro exemplo é o museu paroquial Monsenhor Murilo.

Os turistas, para diferenciar e exemplificar as redes distantes, mas conectadas às outras, romeiros, nativos com relações comerciais e de serviços, seriam outros grupos e também podem trafegar na rede total (Romaria) com menos densidade, pois sua visão seria mais exterior (estereotipada) em relação aos eventos de Juazeiro, que consistiria no olhar mais exótico e, por que não dizer, ocidental.

Os nativos, poderiam ser entendidos como membros locais, eles subsistem em Juazeiroe, nessa rede total, interagem com as duas redes internas mais diretamente.Nesse caso,esses individuos locais se conectam às redes internas da totalidade da qual fazem parte, por meio de produtos e serviços que oferecem, e nas relações sociais de afinidades entre esses grupos. 
Em relação aos grupos de romeiros, é preciso acrescentar para esse entendimento que, mesmo estando localizados em uma camada intermediária e não local, suas relações com a rede total ou como universo romeiro em Juazeiro do Norte é bem mais intensa do que as relações do turista com essa mesma rede total ou Juazeiro.

Seus membros quase sempre mantêm uma relação social perene,em queseusatores são mais assíduos na conexão comessa totalidade, e cujas renovações, partemde uma ancestralidade e tradição que,em estudos, não se observa na rede internadosturistas.

Por outro lado, a rede interna dos turistas, embora mais transitória na maioria dos casos,com raríssimas exceções, movimenta a rede em sua camada total em sua economia de produtos e serviços turísticos que, por este grupo social, são bem mais apreciados em sua totalidade.

Por fim, fica mais claro responder ao que Hennerz (2015) escreve em relação a abstrair o sistema mais amplo,para objetivos mais analíticos e mais ou menos elaborados.

Estar em Juazeiro do Norte, na romaria com os protagonistas alagoanos, é estar conectado a essa grande rede social de várias interconexões, com atmosfera cosmopolita descentralizada de uma antropologia transcendental (AGIER, 2015).

Esse relato é uma forma introdutória para descrever o entendimento de quem é o romeiro alagoano, seu protagonismo e o porquê desse movimento humano social e suas relações na rede total Juazeiro do Norte e nas inúmeras redes que atendem ao chamado das romarias, aqui mais especificamente o de peregrinação e visitação ao túmulo de Pe. Cícero.

Ler o testemunho de que Pe. Cícero era um "santo na terra" é trazer à tona o que se revela na pesquisa "o santo existe e permanece vivo, porque existe o romeiro"; querer ir ao encontro até hoje em peregrinação e ritual é performance de uma imaterialidade; estar em Juazeiro do Norte, peregrinar e visitar o túmulo é a ação da imaterialidade.

Como explicar essa atração e caminhada alagoana ao túmulo de padre Cícero Romão Batista? Como entender o porquê de tantos alagoanos fixaram morada em Juazeiro e que contribuíram significativamente para seu desenvolvimento como foi o caso do senhor Aureliano de Atalaia - AL, comerciante e pai de 36 filhos, Cap. Fernandes desenvolvedor da região também oriundo de Alagoas, se- 
nhor Roque Pinto de Anadia, Alagoas, primeiro administrador da capela do Socorro.

Embora não seja alagoana, para compor esse panteão de romeiros seminais, fazendo alusão a Geertz (2008), destaco ainda a Maria Magdalena do Espírito Santo de Araújo, abeatado milagre,protagonista de uma das mais complexas e importantes ações no contexto das romarias.

\section{Quem é o Romeiro (a)??? Sua vida é andar...}

Mas, enfim, quem são esses protagonistas alagoanos que formam o grupo de romeiros que dão vida a esta etnografia?

Maria Regina, a Maria da Xoxa, nascida em 1960, moradora de Coqueiro Seco, Alagoas, é enfermeira, ministra da eucaristia, neta de romeiros, romeira há quase meio século e, na ocasião da romaria de 20 de julho de 2018, fazia oito meses que seu filho mais velho havia sido assassinado. Enlutada, ela traz em sua voz, enquanto caminha para iniciar a subida do horto, o seguinte: "tem muita gente que vê a cruz como sinal de sofrimento; a gente tem que ver a cruz como exemplo e agradecimento". Estando em Juazeiro, mais perto de "meu padrinho Cícero", Maria Regina diz que, "além da dor do luto que diminuiu bastante, todas as outras dores se vão e até volto a sorrir após oito meses".

Sua mãe era fretantee lembra que desde os 12 anos vêm a Juazeiro do Nor-te. Faz sempre três romarias: a de candeias em janeiro/fevereiro, a de morte do Pe. Cícero em julho e a de Mãe das Dores em setembro.

Peregrinando com seus passos longos de pedra e areia que se junta aos tantos outros, rumo ao santo sepulcro, equilibrando uma garrafa de água em suacabeça, me diz, "professor, enquanto tiver força, não deixo meu Juazeiro e nem meu padrinhoCícero".

Maria do Carmo dos Santos (Carminha) é aposentada, moradora de Coquei-ro Seco, Mestra de Folguedo, filha de fretantes, mãe de fretante (André Ezidio), eximia cozinheira, foi uma das primeiras a falar de suas histórias e memórias de tantas romarias. Conta que foi curada de uma grave enfermidade nas pernas por intercessãode Pe.Cícero e que recorre a ele paratudo. 
$\mathrm{Na}$ ocasião da peregrinação que fizemos juntos, durante a subida de quase $15 \mathrm{~km}$ ladeira acima, era visivel o inchaço em seus pés, mas no seu ritmo completou a peregrinação dizendo que subia com fé e alegria.

José Ezídio dos Santos, 69 anos esposo de Carminha, é aposentado reformado da polícia militar do Estado de Alagoas, morador de Coqueiro Seco, filho de romeiro, apreciador e versado na história do Brasil, a quem tive a grata satisfação de tê-lo como companheiro nas andanças por entre ruas e ladeiras de Juazeiro do Padre Cícero. Ele diz "ei professor... escute muito bem... padre Cícero para mim foi-se embora depressão, desemprego, ele é um santo, não é Deus, mas é santo".

Maria José dos Santos Silva (Nilzete) viúva, moradora de Coqueiro Seco, irmã da ex-prefeita da cidade, condição que é revelada pelos outros protagonistas, romeira de longas datas, embora tenha compartilhado comigo as duas poltronas do ônibus, é a mais reservada, que depois, na dimensão alterizada, me revelou um largo e sincero sorriso. Eu havia ultrapassado a dimensão no aceite dessa romeira que percebeu minha atitude ética em participar da romaria para ela e para mim, elaborando o método prático do campo.

Rosângela Maria de Lima Santos, professora, moradora de Coqueiro Seco, a com menos viagem a Juazeiro do Norte, tem em suas primeiras palavras quando chegávamos aohorto a seguinte memória: "foi aqui professor, em 2017 que me encontrei com o padre Cícero. "Sabe, professor, a fé do povo é a força do Juazeiro".

D.Luzinete,de78anos, é natural de Joaquim Gomes, Alagoas. Reside atualmente em Maceió, bisneta de romeiros e devota de Nossa Senhora do Monte Cabeça, é tirante de Benditos, isto é, é quem inicia, puxa os benditos que são acompanhados por outras pessoas e ao cantar o bendito de Santa Quitéria, olha para câmera como que olhando para meus olhos e pergunta: "tá vendo meu filho, que coisa linda? ". D. Zezé, que reside em Maceió, e D. Fatima (Fau) da Paripueira, bem mais reservadas, mas solícitas de nossa atenção, acompanham D. Luzinete nosbenditos.

Essa análise e apresentação dos primeiros romeiros e, me sugere o estudo da Antropologia do Corpo, como metodologia teórica aos resultados de prática de campo realizada entre os dias 14 e 20 de julho de 2018, em Juazeiro do Norte, 
por ocasião da romaria de morte de Pe. Cícero será mais bem aprofundada nesse capítulo.

A etnografia possibilitou, para mim, a fusão entre a prática de campo e a teorização desses resultados qualitativos na pesquisa. Com a antropologia do corpo foi possível a reflexão dos elementos observados a partir do conceito de sinergia, expressão, toques, gestos, olhares e comportamentos do grupo de oito protagonistas.

O romeiro alagoano é puro toque, expressão, olhar. Observar o grupo dos oito realizando a romaria do dia 20 , dentro da perspectiva do processo ritual e da antropologia do corpo, essa corporalidade do romeiro alagoano encontra-se e se coloca perante o mundo a partir do seu entendimento como agente formador de um processo a partir de seu corpo como agente e não como objeto e de sua corporalidade. Csordas (2008, p. 103) utiliza o pensamento maussiano para justificar a corporalidade em que o próprio Mauss sugere que "todos os humanos possuem uma noção de individualidade espiritual e corporal", esse paradigma se reafirma ao observar os protagonistas das romarias, no processoritual. O romeiro peregrino, sua vida éandar. O sentido do verbo "andar" sempre fez parte do contexto nordestino, está nas canções, nos versos, nos benditos, principalmente na prática das romarias.

Cordeiro (2010, p. 55) escreve:

A noção de peregrinação incorporada no discurso religioso supõe um percurso em direção ao divino e é compreendida tanto em um sentido material de um deslocamento geográfico quanto de um ponto de vista metafórico, correspondente a uma jornada interior.

Analisando o andar do romeiro peregrino considerando o recorte histórico apartir de 1889, pude observar que esse sentido do andar na prática, assume posturas diferentes em direção à cultura das romarias levando em conta "o sentido do pedir", "o sentido do receber e retribuir" e "o sentido da manutenção dessadevoção".

Nos estudos sociológicos, a peregrinação faz parte das práticas rituais características do sistema de crenças que constituemo aspecto religioso da vida. Sua apreensão está voltada para as implicações dessa prática no processo social. Entendendo a religião como construção humana sob o "guarda-chuva" da cultura, os fenômenos de deslocamentos religiosos contemporâneos envolvem 
várias perspectivas de interpretação a respeito das ações e sentidos evocados pelos agentes envolvidos. (CORDEIRO, 2010, p. 57).

Maria de Araújo, Zé Lourenço, os alagoanos contemporâneos ao Pe. Cícero Roque Pinto, Aureliano, Capitão Fernandes e tantos outros que peregrinaram até o Juazeiro depois de 1874 e 1889, buscaram por meio da peregrinação "o pedir" socorro o acolhimento, e dias melhores. Foram socorridos, acolhidos e encontraram dias melhores por meio de uma dinâmica e práxis igualitária que fez Juazeiro do Norte se desenvolver, do qual eles fizeram parte ativamente.

Até1934,anodamortedoPe.Cícero,ofluxoderomeirosvindosdeváriaspartes do Nordeste viam o Juazeiro do Norte como "meca"e o Pe. Cícero como o padrinho conselheiro, perseguido pela Igreja que ele tanto amou e preocupado com a causa dos mais pobres, oprimidos edesgraçados.

Esse caráter provedor do Juazeiro aos que chegavam, entre romeiros, beatos e toda sorte de pessoas por meio da pastoral do sacerdote, permanece alimentando o fluxo das romarias. Dumoulin (2017, p. 247) afirma "e ele fez opção pelos pobres. Consagrou sua vida aos pobres".

Sobre esse expediente, a opção pelos pobres, mesmo sendo nítido o desinteresse por parte do romeiro alagoano sobre qualquer elemento acerca da polêmica e controvertida "riqueza" de Pe. Cícero cabe aqui fazermos de forma muito sintética mas fundamentada, uma análise sobre a questão.

Para isso, vou utilizar a memória privilegiada da leitura do testamento do próprio Pe. Cícero por ocasião a visita ao Memórial Padre Cícero em Juazeiro do Norte em julho de 2018 e que foi transcrito para um livro escrito por Manoel Bergström Lourenço filho em 1926.

Não obstante aos desvios de caráter, condição nata dos homens, do desrespeito daqueles que posteriores ao Pe. Cícero usufruíram e não tiveram a hombridade de descontruirasmentiraseequívocosbibliográficos, deseutestamento, estãoexplicadosa“riqueza"eopoderdePe.Cícero. Aintençãodosacerdotefoisempre a melhor, o desrespeito de muitos foi sempre maior. Na biografia de Pe. Cícero existe uma figura intrigante chamada Floro Bartolomeu que segundo Amália Xavier era uma pessoa perigosa e que de seus atos arbitrários como por exemplo a concessão de patente de capitão a Lampião e o pacto dos coronéis tenham respingado acidamente na batina de Pe. Cícero lhemaculando. Cavalcante(2008, p. 277) transcreve uma resposta dada a ela por romeiros adeptos ao beato José 
Lourenço sobre o comportamento do sacerdote em doar bens à igreja,a reposta foi esta:"o santo se completa nas provações, que por sua vez desmascaram aqueles que impõe estes sacrificios. O Padre Cícero precisava mostrar ao povo quem eram realmente os bons homens da igreja, para que fosse visto que muitos sacerdotes são oanticristo". Aqui se pode dizer que muito claramente, Pe.Cícero explicita que sem o romeiro, Juazeiro acabaria, ou seja, não bastaria os "beneméritos" padressalesianos.

Emcontraparti-

da,paraumajustaanálisedestacooqueescreveuAnselmo(1968,p. 501), através de um testemunho de Vicente Pereira da Silva,citado pelo também escritor Abelardo F. Montenegro, em que Pe. Cícero teria dito "O que Deus não quer, o diabo não enjeita. A igreja não me quer, pois eu memetonapolítica”. Essa opinião jamais encontrou coro entre pesquisadores como professor Daniel Walker, Renato Cassimiro, Renato Dantas, Marcelo Camurça, José Genildo Reges, Maria do Carmo Pagan Forti, entre outros e nem tão menos em publicações sérias sobre o Juazeiro segundo esses mesmos pesquisadores. Será a opinião dos romeirosdiferente?

Fecho aqui essa questão tendo a consciência que essa sintética análise, nem ao menos abalou o campo denso dessa polêmica que se sustenta em dois pilares: O padre Cícero "santo" e provedor do social e o padre Cícero Coronel, concentrador de riquezas, sobre o qual paradoxalmente (WALKER, 2017, p. 21) escreve:

E assim, com altos e baixos, errando e acertando ao longo de quase um século de existência como religioso e político, Padre Cícero construiu e consolidou uma biografia de primeira linha, e seu nome, até hoje, é objeto de estudo, despertando ódio e amor. Ele teve a grandiosidade inerente aos grandes homens e as fraquezas comuns a todo mortal. Contudo, foi uma pessoa extraordinária, afigura mais estudada do clero brasileiro, o homem que colocou Juazeiro no mapa do Brasil e o mais carismático líder político e religioso do Brasil.

Retornando à escrita sobre os fluxos, após a morte de Pe. Cícero em 20 de julho de 1934, historicamente o fluxo de romarias aumentou sem precedentes, incialmente pelo choque e sentimento momentâneo de orfandade física, que logo foi ressignificada em devoção. Segundo Cordeiro (2010, p. 57), "além de sinônimo de peregrinação, o termo romaria é utilizado para designar uma reunião de devotos. 
Com essa reunião e devoção, um sentido de pertença que era construído no processo de mistificação de 1889 passa a ser observado. Dantas (2018) fala até de uma questão mítica, construção oral na qual o Pe. Cícero havia sido levado por anjos ao céu e pedido aos romeiros que continuassem seu legado na terra do Juazeiro do Norte com as peregrinações.

O movimento desse fluxo passa, então, a ser alimentado pela volta desse romeiro que devolve a dádiva recebida pelo legado de Pe.Cícero, pela escolha dos romeiros, pelo protagonismo contemporâneo a ele e pelo sentido de pertencimento do romeiro alagoano na atualidade.

Mauss (2003, p.188) ao trazer algumas questões recorrentes durante toda essa explanação: qual é a regra de direito e do interesse que faz que o presente recebido seja obrigatoriamente retribuído? Que força existe na coisa dada que faz o presente recebido, ser obrigatoriamente retribuído? Isso me leva a problematizar o que leva romeiros de Alagoas retribuírem em forma de peregrinação/romarias, sacrificios suportados com resignação e alegria, as graças alcançadas e mais ain-da, o que faz essas graças serem dadas? A metáfora ${ }^{1}$ que dá título a esse artigo, assume sua materialidade na corporalidade e espontaneidade romeira tão presente e pungente, nas subidas e descidas, ruas e becos de Juazeiro do Norte. Na copa do frondoso Juá, a esperança é cantada nos benditos, ganha ação nos passos tão longos de pedra e areia, no olhar é no toque do romeiro. Estando à sombra dessa cidade, se vê na acolhida, na partilha, no sagrado popular, algo de muito peculiar, familiar e, logo se percebe que durante todo o percurso, para onde se olhe e chegue, para e descanse, as raízes desse inegável fenômeno humano/histórico/social que é o Juazeiro do Norte são alagoanas, desde então, até agora e sempre. A dádiva não morre.

\section{Referências bibliográficas}

AGIER, M.Migrações, Descentramento e Cosmopolitismo: uma antropologia das fronteiras. Maceió: EDUFAL, UNESP, 2015. Cap. 4, p. 155-202.

AUGE, M. Por uma antropologia da mobilidade. Maceió: EDUFAL: UNESP, 2010. Prefácio, cap. 1 e 6, p. 7-26 e 95-104.

ALMEIDA, R. R. de; HOLANDA, C. R. Memorial Padre Cícero e outras histórias / Nova Olinda: Fundação Casa Grande Cariri, 2018.

BARRETO, F. M. de Sá. Padre Cícero. $2^{\circ}$ ed. São Paulo: Editora Loyola, 2002.

BARROS, I. Os Mitos do Sertão. Maceió, 2011 
BARROS, L. O.C. Juazeiro do Padre Cícero: a terra da mãe de Deus. $2^{\circ}$ ed.Fortaleza: Editora Imeph, 2008.

BENEDICT, R. Padrões de cultura.Trad. de Ricardo A. Rosenbusch. Petrópolis: Vozes, 2013.

BENI, M. C. Análise Estrutural do Turismo. $10^{\circ}$ ed. (atualizada). São Paulo:SENAC, 1997.

BLOCH, M. Apologia da História, ou, O oficio de historiador. Trad. de Andre Telles. Rio de Janeiro: Editora Jorge Zahar, 2001.

BRAGA, A. M. da C. Padre Cícero: Sociologia de um Padre,Antropologia de um Santo. Bauru: EDUSC, 2008.

BRAGA, A. M. da C. A Subida do Horto: Ritual e Topografia Religiosa. Debates do NER. Porto Alegre: UFRGS, ano 15, n. 25, jan.-junho de2014.p. 197-214.

BRANDÃO, S.; MARQUES, L. C. L.; CABRAL, N. D. A. e MORAES, A. (org.).História das religiões no Brasil: volume 5. Recife: Ed. Bagaço/Universitária da UFPE, 2010.

CANCLINI, N. G. O patrimônio cultural e a construção imaginária do nacional. Revista do Patrimônio Histórico e Artístico Nacional. Brasília: IPHAN, n. 23, 1994.

CAVA, R. D. Milagre em Joaseiro. $3^{\circ}$ ed. Trad. de Maria Yedda Linhares. São Paulo: Companhia das Letras, 2014.

CORDEIRO. M.P.J. Entre chegadas e partidas: Dinâmicas das Romarias em Juazeiro do Norte. Tese(Doutorado em Sociologia). Fortaleza: UFC, 2010.

CLIFFORD, J. Sobre a autoridade etnográfica.A experiência etnográfica. Rio de Janeiro: UFRJ, 2011.

DEMO, P. Metodologia científica em ciências sociais. $3^{\circ}$ ed. (rev. e ampl.). São Paulo: Editora Atlas, CLIFFORD, J. Sobre a autoridade etnográfica. A experiência etnográfica. 2.ed., 1995.

DUMoulin, A.; GUIMARÃES, A. T.; FORTI, M. do C. P. Anais do III SimpósioInternacional sobre Padre Cícero do Juazeiro: e... quem é ele?Juazeiro do Norte: Banco do Nordeste, 2004.

DUMoulin, A. Padre Cícero - Santo dos Pobres, Santo da Igreja. São Paulo: Paulinas, 2017.

ECKERT, C.; ROCHA, A.L.C. da. A preeminência da Imagem e do Imaginário nos Jogos da Memória Coletiva em Coleções Etnográficas. Rio de Janeiro: ABA publicações. Porto Alegre: UFRGS, 2015. p. 101-116.

FOUCAULT, M.Os corpos dóceis. Vigiar e punir. História da violência nas prisões. Petrópolis:Vozes, 1987.

GEERTZ, C. Uma Descrição Densa: Por uma Teoria Interpretativa da Cultura.A Interpretação da Cultura. Rio de Janeiro: Zahar Editoriais, 2008. 
GONÇALVES, J. R. S. O Patrimônio como Categoria de Pensamento. ABREU, Regina; CHAGAS, Mário (org.) Memória e Patrimônio - ensaios contemporâneos. Rio de Janeiro: Lamparina, 2009.

GONÇALVES, J. R. S. Ressonância, materialidade e subjetividade: as culturas como patrimônio. Horizontes Antropológicos. Porto Alegre: UFRGS, v. 11, n. 23, 2005. p. 15-36.

GONÇALVES, J, R. S. Edward Sapir: Forma Cultural e Experiência Indivíduo.Sociologia\&Antropologia. Rio de Janeiro: UFRJ, 02(04), 2012. p. 25-33

GUIMARAES, Therezinha Stella; DUMOULIN, Anne. O Padre Cícero: por ele mesmo. Petrópolis: Vozes, 1983.

GUIMARÃES, Therezinha Stella; DUMOULIN, Anne. Romeiros/as e romarias em Juazeiro do Norte protagonismo de uma liturgia popular uma visão antropológica. Revista de Cultura Teológica. São Paulo: PUC-SP, v. 17, n. 67, abril-junho de 2009.

GUIMARÃES, Therezinha Stella. Padre Cícero e a nação romeira - estudo psicológico da função de um "Santo" no Catolicismo Popular.Fortaleza: IMEPH, 2011.

HALL, S. A identidade em questão. A identidade cultural na pós-modernidade. Rio de Janeiro: DP\&A, 2006. P.07-22.

HALBWACHS, M. Memória Coletiva e Memoria Individua.A Memória Coletiva. São Paulo: Vértice, 1990.

HANNERZ, U. Fluxos, fronteiras, híbridos: palavras-chave da antropologia transnacional. Rio de Janeiro: Contracapa, 1997.

LARAIA, Roque de B. Cultura: um conceito antropológico. $14^{\circ}$ ed. Rio de Janeiro: Jorge Zahar Ed., 2001.

MADEIRA, M.das G. de L.; SAMPAIO, W. C (org.). Missionários e Beatos nos Sertões Nordestinos - ações socializadoras e formativas (séculos XVIII-XX).Maceió: EDUFAL, 2011.

MAUSS, M. Sociologia e Antropologia. São Paulo: COSAC NAIFY, 2003.

MAUÉS, Raymundo Heraldo. A Mãe e o Filho como peregrinos: dois Modelos de peregrinação católica no Brasil. Religião e Sociedade. Rio de Janeiro: ISER, 2013.

MEDEIROS, D. H. de. Padre Cícero: o milagreiro do sertão? Rio de Janeiro: Editora do Brasil, 1989.

NETO, L. Padre Cícero: poder, fé e guerra no sertão. São Paulo: Companhia das Letras, 2009.

NEGRÃO, L. N. Revisitando o Messianismo no Brasil e Profetizando seu Futuro.RBCS. São Paulo: ANPOCS, v. 16, n. 46, junho de 2001.

NOBRE.E. Dos S. Ilustres desconhecidas: as beatas de Ibiapina no jornal "A voz da religião no Cariri”. Anais do XXVI Simpósio Nacional de História - ANPUH, São Paulo, julho 2011. 
NOBRE. E. Dos S. O sagrado e a teatralização do mundo: espaços de Salvação e purgação nos relatos das Beatas do Padre Cícero (1868-1870). Revista de História. São Paulo: USP, n. 169, julho-dez. de 2013. p. 381-409.

OLIVEIRA, R.C. O Trabalho do Antropólogo: Olhar, Ouvir, Escrever. Revista de Antropologia. São Paulo: USP, v. 39, n.1, 1996. p. 13-37

OLIVEIRA, R. C. Tempo e Tradição.Sobre o Pensamento Antropológico. Rio de Janeiro: Tempo Brasileiro,2003.

OLIVEIRA, J.P. de. Pluralizando tradições etnográficas: sobre um certo mal-estar na Antropologia. Cadernos do LEME. Campina Grande, v. 1, n. 1, jan.-jun. de 2009. p. 2-27.

OLIVEIRA, A. M. de; HERBES, N. E. Espiritualidade, Fé e Cura: um olhar sobre a Religiosidade Popular. Id on Line Rev. Psic. V.10, N. 31. Supl 2, Set-Out/2016 ISSN 1981-1179.

PEREIRA DE QUEIROZ, M. I. Messianismo no Brasil e no Mundo. São Paulo: Dominus/Edusp, 2003.

PIMENTEL, J. S. Os Milagres do Joaseiro. Caicó (Rio Grande do Norte): Typographia Democrata de J-Renaud, 1892.

RABELO, M. C.. A possessão como prática: esboço de uma reflexão fenomenológica. Mana. Rio de Janeiro: UFRJ, 14(1),2008. p. 87-117.

RABELO, M. C. Estudar a religião a partir do corpo: algumas questões teóricometodológicas.Caderno CRH. Salvador: UFBA, 24(61), 2011.p. 15-28.

RABELO, M. C. Religião e a Transformação da Experiência: notas sobre o estudo das práticas terapêuticas nos espaços religiosos. Mha. Florianópolis: UFSC,n. 7, 2007, p.125-145.

RABELO, M. C.Enredos, feituras e modos de cuidado. Dimensões da vida e da convivência no candomblé. Salvador:EDUFBA, 2014.

RAMOS, F. R. L. O meio do mundo: território sagrado em Juazeiro do Padre Cícero. Fortaleza: Imprensa Universitária, 2014.

RAMOS, F. R. L. Papel Passado- cartas entre os devotos e o padre Cícero. Fortaleza: Instituto Frei Tito de Alencar, 2011.

SANTANA, E. H. de M. Padre Cícero do Juazeiro: Condenação e Exclusão Eclesial à Reabilitação Histórica. Editora. EDUFAL, 2009.

SILVEIRA, Emerson J. Sena da. Turismo religioso popular? Entre a ambiguidade Conceitual e as oportunidades de mercado. Revista de Antropología Experimental. España: Universidad de Jaén, n. 4, out. de 2004.

SILVEIRA, Emerson J. Sena da. Turismo Religioso no Brasil: uma perspectiva local e global. Turismo em Análise. São Paulo: USP,v. 18, n. 1, maio de2007. p. 33-51. 
STEIL, C.A.;MARIZ, C.L.; REESINK, M.L. Maria entre os vivos. Porto Alegre: Editora UFRGS, 2003.

SOARES DO BEM, A. A Centralidade dos Movimentos Sociais na Articulação Entre o Estado e a Sociedade Brasileira nos Séculos XIX e XX. Educação e Sociedade. Campinas, vol. 27, n. 97, set.-dez. de 2006. p. 1137-1157.

SOBREIRA, Pe. A. O Patriarca de Juazeiro. $3^{\circ}$ ed. Juazeiro do Norte: UFC, 2011.

SOUZA, S. (Coord.). História do Ceará (vários autores). Fortaleza: Universidade Federal do Ceará/Fundação Demócrito Rocha: Stylus Comunicações, 1989.

TURNER, V. O Processo Ritual. Estrutura e Anti-Estrutura. Petrópolis: Vozes, 1974.

TURNER, V. Dramas, Campos e Metáforas. Rio de Janeiro: EDUFF,2008.

TURNER, V. Floresta de Símbolos: aspectos do ritual Ndembu. Niterói: Editora da Universidade Federal Fluminense,2005.

WAGNER, R. A presunção da cultura.A invenção da cultura. São Paulo: Cosac \& Naify, 2012.

WALKER, D. Padre Cícero, Lampião e coronéis. Fortaleza: Expressão Gráfica e Editora, 2017.

\footnotetext{
1 A metáfora "A copa do Juazeiro é verde, as raízes são alagoanas" se dá pelo fato da forte presença de romeiros alagoanos em todos os ciclos de romarias, além da própria construção social do Juazeiro do Norte, com muitos personagens que oriundos de Alagoas, escreveram sua história, estão enterrados no Juazeiro e muitos de suas posteridades ainda vivem na terra da Mãe de Deus.
}

Recebido em 29/06/2021

Aceito para publicação em 30/08/2021 


\section{A estirpe de conselheiros do catolicismo popular sertanejo do nordeste brasileiro}

The strain of advisers of popular Catholicism in the backwoodsof

northeasternBrazil

https://doi.org/10.29327/256659.12.2-12

\section{Resumo:}

Este artigo trata dessa "matriz geradora de uma estirpe de conselheiros do povo". O fenômeno religioso que se constituiu em torno dos conselheiros se deu basicamente na região do sertão nordestino, no semiárido, o que não exclui que seguidores tenham saido de outras sub-regiões. Movimentos dessa natureza dizem respeito à tradição e à cultura popular sertaneja, que têm raízes nas culturas africanas e indigena. Nas pequenas cidades do interior do Nordeste, ainda hoje deparamos com os conselheiros e as conselheiras que auxiliam as pessoas da comunidade, aconselhando-as em suas angústias, suavizando os seus sofrimentos. Essa estirpe cultural merece ser examinada mais de perto porque revela essa dimensão ainda pouco estudada do catolicismo popular brasileiro: a figura do conselheiro. Para estudar a estirpe de conselheiros, o ponto de partida foi recolher o material existente nas pesquisas bibliográficas e documentais.

Palavras-chave: Estirpe. Conselheiro. Nordeste.

\section{Abstract:}

This article deals with a "matrix that generates a strain of councilors of the people". The religious phenomenon that has taken place around the councilors occurs basically in the region of the Brazilian northeastern backwoods, in the semiarid region, which does not exclude that followers have left other sub-regions. Movements of this nature concern the tradition and popular culture from these backwoods, which are rooted in African and indigenous cultures. In small towns in the inner part of the northeast region, we still come across counselors who help people in the community, advising them in their anguish, softening their suffering. This cultural strain deserves to be examined more closely because it reveals this still-under-studied dimension of Brazilian popular Catholicism: the figure of the councilor. In order to study the strain of counselors, the starting point has been to collect the existing material in bibliographic and documentary research.

Keywords: Strain; Counselor; North East.

*Doutorando em Ciências da Religião pela PUC Minas (2019-2022). Mestre em Ciências da Religião pela PUC-Minas. Especialização em Docência no ensino superior: novas linguagens e novas abordagens pela PUC Minas. Licenciatura Plena em Filosofia pela PUC Minas. Professor de Educação Básica da Secretaria do Estado da Educação de Sergipe. Membro da SOTER.E-mail: jooevertoncruz@yahoo.com.br. 


\section{Introdução}

Neste artigo tentarei evidenciar a estirpe de conselheiros do catolicismo popular sertanejo do Nordeste brasileiro. São eles: o padre José Antônio Maria Ibiapina1 (1806-1883), beato Antônio Vicente Mendes Maciel2 (1830-1897), padre Cícero Romão Batista ${ }^{3}$ (1844-1934) e frei Damião de Bozzano4 (1897-1997) que inte-gram essa forma de catolicismo, na segunda metade do século XIX e primeira do século XX. Ao estudar esse tema como estudante da primeira turma de mestrado (2010) em Ciências da Religião do Programa de Pós-Graduação da PUC Minas, impressionou-me a complexidade dessa estirpe de conselheiros, aparentemente tão simples, sob a orientação do Prof. Dr. Pedro A. Ribeiro de Oliveira.

O fenômeno religioso é parte integrante de toda a história da humanidade, pois, a Fenomenologia da Religião vê na religiosidade um dos elementos da natureza humana. Por isso, a experiência religiosa implica em um sentimento de comunhão profunda com outras pessoas, com a natureza e com o sagrado. O sertanejo do Nordeste brasileiro ao longo dos anos apropriou-se dessa tradição de estirpe de conselheiros via o substrato religioso. A tradição religiosa dos nordestinos revive, porém diluída no tempo, é uma grandeza de variante oral, alicerçado na memória popular e revitalizada pela recordação itinerante, atraindo fatos e figuras. São as pessoas dos "velhos curas", do "padrim-padre", do "padre-mestre" e do missionário, celebrando, confessando, pregando, casando, aconselhando, dirimindo desavenças, emudecendo bacamarte e cravando cruzes em pontos elevados, sobretudo nas classes populares por meio dos antigos missionário, romeiros, cangaceiros, vaqueiros, poetas, cordelistas, parteiras, rezadeiras, leigos, beatas e beatos ${ }^{5}$, sendo padre Ibiapina "essa figura matricial" da estirpe de conselheiros na segunda metade do século XIX.

O Nordeste do Brasil abrange os Estados do Maranhão, Piauí, Ceará, Rio Grande do Norte, Paraíba, Pernambuco, Alagoas, Sergipe e Bahia. A região Nordeste tem a sua riqueza geográfica, dividida em quatro sub-regiões, bem distintas, com diversas condições climáticas e culturais. O litoral, com chuva constante; o sertão-semiárido, com escassas chuvas e intermináveis secas; o agreste e a zona da mata com chuvas abundantes. O fenômeno se deu basicamente na região do sertão nordestino, no semiárido, ao Norte do rio São Francisco.

O artigo está organizado em dois capítulos, dialogando com as leituras das pesquisas existentes e da bibliografia documental.

O primeiro capítulo abre com "as malhas diversificadas de um catolicismo, 
ou poder-se-ia mesmo falar em catolicismos no plural", na perspectiva de Faustino Teixeira (TEIXEIRA, 2009, p. 19-20). O segundo capítulo apresenta uma breve biografia de cada um dos conselheiros.

\title{
Conselheiros do catolicismo popular: sertanejo?
}

A tradição do catolicismo popular sertanejo do Nordeste brasileiro, onde surge "essa matriz geradora de uma estire de conselheiros do povo" foi uma questão lançada por Eduardo Diatahy B. de Menezes,

\begin{abstract}
Mas quem foi Ibiapina, essa matriz geradora de uma estirpe de conselheiros do povo (Antônio Vicente Mendes Maciel, Padre Cícero, Beato Lourenço, etc), instituindo nos sertões nordestinos da segunda metade do século XIX uma grande escuta dos anseios e aflições de larga massa de excluídos, e inaugurando uma forma de organização que a nossa civilização litorânea dominante teimará em não aceitar e até em hostilizar ou destruir sistematicamente quase todas as suas manifestações (MENEZES, 1996, p. 2).
\end{abstract}

A experiência religiosa de um conselheiro, especificamente, possa se assemelhar ou não com a experiência do aconselhamento do outro, configurando semelhanças e dessemelhanças entre eles. São todos nascidos em anos mais ou menos subsequentes. Uma nota a ser feita é que o conselheiro não é necessariamente um especialista da hierarquia da Igreja Católica. Duglas T. Monteiro retoma José Calasans para distinguir o conselheiro do beato pelo fato de seu "reconhecimento e aceitação como predicadores" (MONTEIRO, 1985, p. 69). Convém ainda observar que tanto padres quanto beatos ou beatas podem tornar-se conselheiros. Desse modo, Galvão diz que:

Antônio Conselheiro é apenas um entre os vários conselheiros de que há notícias na época: havia um por nome Francisco, em Itiúna, na Bahia, outro por nome Guedes, em Pernambuco, e outros mais. Assim eram designados no sertão os leigos andarilhos pregadores de sermões, chamados "conselhos" por não provirem de padres ordenados. (GALVÃO, 2001, p. 32).

A grande figura do padre conselheiro é, sem dúvida, o Pe. Cícero Romão Batista. Também o missionário frei Damião de Bozzano, um remanescente da disciplina tridentina, dava muita atenção à confissão e ao aconselhamento público em seus sermões, respondendo bilhetes que lhe mandavam ou the chegavam às mãos. 


\title{
O catolicismo popular: a dinâmica da produção religiosa
}

Para conhecer as diferentes formas de catolicismos existentes no Nordeste do Brasil, apelamos para a sociologia, porque exibe a dimensão humana e social de toda e qualquer religião. O catolicismo popular está presente no Brasil desde a chegada dos colonizadores portugueses, conquistando as terras e subjugando os povos indigenas. A expressão catolicismo popular é conceituada algumas vezes como "religião popular", "catolicismo rural", dentre outros, conforme Silva (2005, p. 20). Segundo o sociólogo Pedro A. Ribeiro de Oliveira (1985),

\begin{abstract}
A autoprodução religiosa popular não fica portanto separada da produção oficial, mas guarda com ela uma relação dialética: ela exprime as condições de existência das classes dominadas e subalternas, fazendo uso dos códigos religiosos oficiais. Podemos então definir o Catolicismo Popular como um conjunto de representações e práticas religiosas autoproduzidas pelas classes subalternas, usando o código do catolicismo oficial. Isso significa que o Catolicismo Popular incorpora elementos do catolicismo oficial os significantes - mas lhes dá uma significação própria, que pode inclusive opor-se à significação que lhes é oficialmente atribuída pelos especialistas. O resultado é que o mesmo código religioso é diferentemente interpretado pelas classes sociais de maneira que, sob uma unidade formal, escondem-se, de fato, diversas representações e práticas religiosas (OOLIVEIRA, 1985, p. 135).
\end{abstract}

O centro do catolicismo popular é a devoção ao santo e santa, do qual se espera proteção para superar as dificuldades e resolver os problemas desta vida, bem como obter a salvação eterna. As suas práticas religiosas são de âmbito familiar e em pequenos grupos e manifestam-se por atos concretos ligados ao cotidiano, como rezar para pedir chuva, visitar doentes e fazer leitura da Bíblia ${ }^{6}$. Esse catolicismo conta com os rituais oficiais (missa e sacramentos) e acrescenta novos sentidos para torná-los mais funcionais para sua vida (batismo-saúde, confissão-cura, sacramento-compadrio). Os rituais, além de situar contato com o sagrado, permitem recriar a consciência coletiva do povo. É um catolicismo conduzido pelos leigos e leigas. Não se pode concluir que seja um catolicismo independente do catolicismo romanizado, mas se trata de uma retradução do mesmo.

\section{Catolicismo popular sertanejo: a tradição camponesa de devoção}

É certo que o catolicismo popular sertanejo nos dias de hoje quase não existe mais, devido ao grande combate que ele tem aturado. Muito embora ainda restem tradições das velhas práticas, nas pequenas regiões onde há ausência de 
padres. A deficiência de padres no Brasil é caso que pode ser datado do período colonial. Os clérigos originários do "além-mar" eram em pequenina quantidade. As populações interioranas - nordestina com toda sua extensão ficaram sem sacerdotes. Ali se conservou um catolicismo popular sertanejo, com suas formas de crer e de agir especificamente, cultivada por leigos e leigas que se arvoravam nos assuntos religiosos, a fim de orientar o povo. Mais tarde, é verdade, com a Proclamação da República, as Ordens Religiosas estrangeiras passaram a enviar sacerdotes em maior quantidade para o Brasil, respeitado "pais das santas missões". Isto porque, esclarece Thomás Bruneau (1974, p. 29), e segue sucintamente: a) estar presentes, segundo um princípio organizacional, em todo território, por meio das missões, capelas, paróquias e dioceses; b) possuir, inclusive pela força, o monopólio dos fiéis, convertendo e/ou evangelizado a brancos, negros e índios; c) constituir e regulamentar a sociedade, visando à salvação, inclusive com o apoio do Estado, desde o batismo até a extrema-unção, mediante ensinamentos religiosos e morais; d) utilizar os grupos sociais e as estruturas, inclusive as do Estado, como instrumentos de influência.

Muitos dos sacerdotes estrangeiros nas missões procuraram implantar entre o povo práticas e crenças mais ligadas ao catolicismo romanizado, mas, o sertanejo dava mais ouvidos aos beatos, que aos sacerdotes ordenados, preferindo seus conselhos às missas formais e demais sacramentos. Esse foi o catolicismo difundido no sertão do Nordeste pelos missionários por meio das santas missões, sobretudo pelos capuchinhos franceses e italianos. Eduardo Hoornaert, com outra preocupação, esclarece de outra forma, a mesma coisa que:

O sertanejo nordestino vive imerso num mundo referencial bíblico e cristão, reconhece os símbolos, sabe interpretar as figuras. É herdeiro de uma longa e bonita tradição teológica, sendo ele mesmo teólogo. Teólogo sofrido, de mãos calejadas, mas teólogo. Embora não acostumado ao mundo das letras, produz versos, poesias e textos que não são de forma nenhuma simplórios, mas carregados daquela sabedoria sofrida típica do povo da terra, feita de desencanto mas também de uma esperança indestrutivel. Sertanejo-teólogo, cioso em descobrir o sentido mais profundo das coisas, concentrado em encontrar uma leitura teológica dos fatos que presencia. Não cartesiano no sentido de se operar uma rígida separação entre a racionalidade e a emotividade, entre os conceitos claros e as imagens, entre o experimentado e o sonhado. Mas um curioso das coisas de Deus, atrás do sentido último. Sua teologia é mística e escatológica, espera um tempo bom após tanto sofrimento. Com o dizia Câmara Cascudo: o sertanejo é teólogo "antes, durante e depois dos concílios ecumênicos e dos Santos Padres" 
(HOORNAERT, 1997, p. 63-64).

A devoção sertaneja nordestina corresponde a uma cultura de tradição baseada na oralidade. No catolicismo popular sertanejo existe uma hierarquia, o beato está abaixo do conselheiro. O beato tinha como função angariar esmolas para edificação de igrejas, capelas, cemitérios, e conduzia os cantos, puxava terços, dirigia as rezas. O beato podia ter uma progressão, quando ele "adquiria condições para, além disso, proferir prédicas, ou conselhos, passava a conselheiro" (GALVÃO, 2001, p. 33). Os papéis desses religiosos leigos são definidos por José Calasans Brandão da Silva,

\begin{abstract}
Admitimos, na igreja popular sertaneja, uma hierarquia, com beatos e conselheiros. Tivemos, como já foi dito, nossa atenção despertada para o assunto numa conversa com Honório Vilanova, em terras do Assaré. Disse-nos que conhecera, por volta de 1873, no Ceará, o beato Antônio, que iria encontrar, depois, na Bahia, como conselheiro. Explicou-nos que conselheiro era mais do que beato. Ao beato cabia a missão de tirar rezas, cantar ladainhas, pedir esmolas para obras da igreja. O conselheiro ia além, porque, melhor preparado sobre os temas religiosos, pregava, dava conselhos. Um conselheiro pode ter, debaixo de suas ordens, um ou vários beatos. Foi o caso de Antônio Conselheiro, ao qual estavam subordinados alguns beatos, como o beato Paulo, José Beatinho, Antônio Beatinho, além de outros que não nos foi possivel identificar (SILVA, 1986, p. 13).
\end{abstract}

Durante a pesquisa, deparamo-nos com várias pessoas que exercem a função de conselheiros na sua localidade, pois, são reconhecidas por algumas qualidades que os caracterizam: virtudes pessoais, força da palavra, capacidade de ouvir, intimidade com os santos. Em Canudos (BA), Antônio Conselheiro (1830-1897) usava a Missão Abreviada e as Horas Marianas diariamente. Era uma espécie de pequeno Manual dedicado a Maria, Mãe de Jesus Cristo. Em decorrência da renovação estabelecida pelo episcopado através do Concílio vaticano I, o catolicismo popular sertanejo baseado na figura do beato é interpretado como negação à prática do catolicismo romanizado e não como uma forma popular de fazer catolicismo. Esse preconceito por parte da cultura oficial ocorre em não pretender compreender os diferentes elementos significativos que constituem esse catolicismo, estabelecendo uma dicotomia cultural que se exprime na existência de uma cultura oficial dominante e outra meramente popular e muitas vezes considerada como algo periférico e supersticioso. 


\section{Catolicismo romanizado: influência na organização da vida eclesiástica}

O catolicismo romanizado pode ser datado a partir de 1858. A inquietação do catolicismo romanizado era afugentar os fiéis do catolicismo popular e orientá-los para a prática do catolicismo romano, com ênfase nos sacramentos. Sobre a "romanização" do catolicismo brasileiro, Pedro R. de Oliveira diz que:

Um documento confidencial de D. Macedo Costa, intitulado "Pontos de reforma na Igreja do Brasil", apresenta as grandes linhas de reforma por ele propostas ao conjunto do episcopado brasileiro. Redigido em 1890, ele tem cerca de 20 páginas e é dividido em 9 capítulos. Analisando suas propostas, teremos um panorama do projeto de reformas do líder do episcopado brasileiro no início do período republicano (OLIVEIRA, 1985, p. 279-280).

No catolicismo romanizado os sacramentos assumem caráter obrigatório e um dos pontos levantados é, pois, a sua uniformidade de ação do episcopado brasileiro, como um único corpo, reforçando a sua autoridade diante do clero e hierarquia. O objetivo do catolicismo romanizado é a reforma do aparelho eclesiástico, sob outros aspectos, a regeneração religiosa do povo. A evangelização da sociedade brasileira foi marcada por duas tendências: a "pastoral da convivência" e a "pastoral da visita", assim destaca E. Hoornaert. (HOORNAERT, 2008, p. 125-133). Mesmo escassa, essa convivência servia para garantir o laço de pertencimento do catolicismo popular ao catolicismo oficial por meio de um consentimento religioso que fazia com que os diferentes grupos sociais que viviam espalhados pelo sertão admitissem como pertencentes à única e mesma Igreja da hierarquia eclesiástica. Há uma distância que marca a religiosidade e a vivência concreta do sertanejo; sendo que essa vivência religiosa pouco auxilia para a libertação dos seus problemas, desencadeando na mistificação, alienação e até opressão. A fome, a seca, a miséria e a pobreza seriam então transfiguradas como decorrência de leis divinas e, portanto, imutáveis. Bourdieu evidencia o caráter dominante da religião, quando diz que

Neste ponto, Weber está de acordo com Marx ao afirmar que a religião cumpre uma função de conservação da ordem social contribuindo, nos termos de sua própria linguagem, para a "legitimação" do poder dos "dominantes" e para a "domesticação dos dominados". E ademais, Weber nos fornece os meios de escapar à alternativa simplista de que são produto suas análises mais duvidosas, ou seja, à oposição entre a ilusão da autonomia absoluta do discurso mítico ou religioso e a teoria reducionista que torna esse discurso o reflexo direto das estruturas sociais. Procura esclarecer 
ao máximo o elemento comum ausente no discurso das duas posições opostas e complementares: o trabalho religioso realizado pelos produtores e porta-vozes especializados, investidos do poder, institucional ou não, de responder por meio de um tipo determinado de prática ou discurso a uma categoria particular de necessidades próprias a certos grupos sociais. (BOURDIEU, 1974, p. 32-33).

O contexto sociológico onde acontece o fenômeno religioso em torno dos notáveis conselheiros é o sertão nordestino. Com a estirpe de notáveis conselheiros dentro das expressões religiosas sertanejas que vivia sob os olhares e o controle da hierarquia eclesiástica, que tinha como critério de valor a observância da "lei" e da "obrigação", é o que veremos a seguir.

\section{Padre Ibiapina, Beato Antônio Conselheiro, Padre Cícero e Frei Damião: a estirpe de conselheiros}

A estirpe de conselheiros do catolicismo popular sertanejo é uma herança cultural que se propagou por muito tempo, tendo maior valor os padres missionários que davam mais conselhos ${ }^{7}$. Os bons confessores eram, portanto, todos aqueles que seguravam aos seus pés o devoto, por mais tempo, dando conselhos e mais conselhos. A distância que nos afasta dos notáveis conselheiros da memória dos sertões nos permite discernir com exatidão a importância das suas vidas e de suas obras materiais e espirituais para a população do Nordeste brasileiro. Vejamos cada um deles.

\section{Padre Ibiapina}

José Antônio de Maria Ibiapina8 nasceu em 5 de agosto 1806, na fazenda Morro da Jaibara, em Sobral (CE). Era conhecido como Pereirinha. Filho de Francisco Miguel Pereira e Tereza Maria de Jesus. Seu pai era um agricultor em Sobral e tabelião no Icó. Sua mãe falecera vitimada por abortamento. Em 1824, seu pai e o irmão Alexandre participaram da revolução denominada Confederação do Equador. O pai foi fuzilado em praça pública em Fortaleza em 7 de maio de 1825. Quanto a seu irmão, foi preso e levado para Fernando de Noronha, onde faleceu. Os bens da família foram confiscados e José Antônio Ibiapina assume o comando da família. O nome "Ibiapina" foi uma homenagem do pai ao vilarejo que o recebeu nos primeiros anos de seu casamento, por isso decidiu colocar o nome do lugar em um dos filhos, daí que Ibiapina é o terceiro filho do casal e o primeiro a portar esse sobrenome. Ibiapina passa sua infância na cidade de Icó, 
para onde migrou a família, já que o pai foi nomeado tabelião, aí morando até 1819, quando foi transferido para a cidade do Crato (CE), residindo até meados de 1823. Em 1820, Ibiapina foi para a cidade de Jardim (CE), onde frequenta a aula de latim com o mestre Joaquim Teotônio Sobreira de Melo. Em 1823, Ibiapina, com 17 anos, foi com a família para Fortaleza, tendo seguido logo depois para o Seminário de Olinda, com o desejo de ser padre. Com a perda do pai em 1825, teve que voltar para o Ceará assumindo a direção da família e, com isso, interrompe seus estudos. No dia 3 de fevereiro de 1828, foi matriculado, pela segunda vez, no Seminário Episcopal de Olinda. No dia 11 de agosto de 1827 foi criado o curso de Ciências Jurídicas e Sociais em Pernambuco, e instalado em 15 de maio de 1828 no Mosteiro de São Bento, na cidade de Olinda. Aprovado nos exames preparatórios, Ibiapina foi matriculado com mais de quarenta companheiros. As aulas tiveram início em 2 de junho e a incompatibilidade de horários levou Ibiapina a fazer uma outra opção pelos estudos jurídicos, passando a residir no Mosteiro de São Bento.

Ibiapina foi um homem público. Após concluir o curso jurídico, seu nome foi remetido ao Ministério para fins de nomeação de professor de Direito Natural, que foi aceito por unanimidade no dia 10 de outubro de 1832. Com a chegada das férias escolares, resolveu viajar ao Ceará para rever familiares e amigos; acabou conhecendo Carolina Clarence de Alencar Araripe (1867), por quem se apaixonou, marcando o casamento para as férias escolares seguintes. Encerrando o ano letivo, retornou ao Ceará para realizar o casamento e acertar a nova residência no Rio de Janeiro como deputado geral. Mas, ao chegar a Fortaleza, recebeu a notícia de que a noiva havia fugido e se casado com o primo Antônio Ferreira Lima Sucupira. Após o encerramento da sessão legislativa de 1834, Ibiapina viaja para o Ceará para assumir as funções de Juiz de Direito e Chefe de Polícia de Quixeramobim (CE), trabalhando por pouco tempo. Ibiapina não aceitou a Presidência da Província de Pernambuco (governador), tampouco a pasta do Ministério da Justiça.

A partir de 1838, Ibiapina passou a residir no Recife (PE), mas foi convidado para advogar na Vila Real do Brejo de Areia (PB). Por volta de 1840, fixa morada em Recife, onde instalou escritório de advocacia no pátio do Carmo, por dez anos, recebendo o título de "defensor dos pobres", por ser um dos mais notáveis advogados do Recife (PE). Sua vida em reclusão foi por volta dos 1850 a 1853. Sendo que, em 1850, Ibiapina fechou o escritório e renunciou à carreira de advogado, passando a residir numa casa de tijolos no sítio Caxangá, no Recife, 
recluso na solidão, rezando, estudando teologia e filosofia. Para uns, monge; para outros, louco. Seja como for, cuidava do jardim e do pomar, em companhia da irmã caçula Ana, e mantinha contato com o bispo Dom frei João Marques da Purificação Perdigão. Dom João foi quem o ordenou, recebendo a tonsura clerical aos 11 de junho de 1853. No dia seguinte aos 12 de junho do mesmo ano recebeu as duas primeiras ordens menores de hostiário e leitor. E, aos 18 de junho de 1853, recebeu as ordens de exorcista e acólito. No dia 19 de junho lhe foi conferido o subdiaconato. No dia 26 de junho, o diaconato. No dia 3 de julho ordenou-se sacerdote aos 47 anos de idade. No dia 26 de julho de 1853, celebrou a primeira missa na Igreja Madre de Deus, no Recife. Sobre as obras e peregrinações do Pe. Ibiapina, Diana Rodrigues Lopes diz que

Padre Ibiapina, no seu incansável trabalho missionário, percorreu mais de $\mathbf{6 0 1 . 7 5 8}$ quilômetros pelas estradas do Piauí, Ceará, Rio Grande do Norte, Paraíba e Pernambuco, com sua batina de brim pardo ou branco, a pé, a cavalo, ao sol, a chuva, enfrentando doenças e animais ferozes e poderosos fazendeiros. Realizou missões, organizou o povo, conciliou velhas intrigas, levantou e restaurou capelas e igrejas, fundou hospitais, construiu açudes, cacimbas, poços, barragens em mutirão, com a comunidade pobre e sofrida do sertão, sem nenhum apoio e ajuda oficial. Construiu 22 Casas de Caridade, para atender a carentes e órfãs, que eram entregues às irmãs de caridade ou chamadas de beatas. Nas Casas de Caridade as abrigadas aprendiam a ler, escrever e contar, educação religiosa e moral (LOPES, 2004, p. 37, negritos da autora).

Padre Ibiapina, no decorrer dos trinta anos de ação missionária, influenciou a intensificação do preparo de beatos-leigos, no sertão, levando ao povo sofrido nordestino palavras de conselho, atuando na conversão e no acolhimento com suas 22 Casas de Caridade, aos órfãos vítimas do cólera. Como conselheiro do povo, foi, à maneira dos antigos santos e missionários, suscitando inevitáveis ambiguidades, incompreensões; causando conflitos e tensões de renovação dentro da hierarquia eclesiástica face ao movimento dos beatos que surgiu no século XIX, com ele mesmo. Em Serra Talhada (PE), o missionário Ibiapina promoveu a paz entre famílias em litígio, segundo Francisco Sadoc de Araújo:

Ordenou que cavasse um buraco em frente da matriz, para ali serem enterradas todas as armas brancas e de fogo, que estivessem em poder de particulares. Com esse gesto simbólico, pretendia levar inimigos políticos à reconciliação e famílias desavindas à convivência amistosa e à paz doméstica. Com menos armas disponíveis, também o cangaceirismo, que se alastrava pelo sertão, haveria de diminuir (ARAÚJO, 1996, p. 309). 
Foi protetor da natureza, pacificador e introduziu no sertão a prática do mutirão, levando ao cooperativismo. Padre-Mestre Ibiapina morreu no dia 19 de fevereiro de 1883, em sua residência ao lado da Casa de Caridade de Santa Fé (PB), numa segunda-feira da segunda semana da quaresma, aos 77 anos de idade. A fama de santidade, firmada no exercício heróico das virtudes e guardada na memória popular, fundamentou a abertura de sua causa de canonização, ora em tramitação no Vaticano.

\title{
Beato Antônio Conselheiro
}

Antônio Vicente Mendes Maciel$^{9}$ (1830-1897), o futuro Antônio Conselheiro, que era filho de Vicente Mendes Maciel e Maria Joaquina do Nascimento - de alcunha Maria Chana -, nasceu na Vila do Campo Maior de Quixeramobim (CE). Com o falecimento de sua mãe, seu pai teve de casar-se pela segunda vez. O menino Antônio Vicente era apegado à sua mãe. As divergências entre o menino e sua madrasta começam a tomar proporções assustadoras, a ponto de esta induzir o marido a internar o menino num seminário. O pai concordou com a ideia, mas, o filho se posicionou de forma antípoda, preferindo permanecer sob o desprezo, o autoritarismo, a arrogância e os maus-tratos da madrasta. Daí por diante o clima familiar era da mais completa hostilidade ao garoto. Em 1857, Antônio Maciel casa-se com Brasilina Laurentina de Lima, na matriz de Quixeramobim. Foi caixeiro viajante, auxiliar de cartório e professor. Eduardo Hoornaert afirma que:

\begin{abstract}
Seu companheiro de infância, o jornalista João Brígido, conta em 1917 que Antônio Vicente teve uma aprimorada formação em letras primárias e latim, ainda em Quixeramobim, o que lhe deu condições de exercer mais tarde as funções de escrivão do juiz de paz em Ipu. Dos tempos em que estudava com seu mestre de latim e gramática em Quixeramobim, guardou uma boa capacidade de escrever e traduzir frases biblicas, conforme se pode averiguar nos cadernos guardados. Toda essa ambientação, que não era incomum no sertão do século XIX, fez dele um "homem de letras", e mais tarde um escritor (HOORNAERT, 1997, p. 114).
\end{abstract}

Em 1860, Antônio muda-se para a cidade de Campo Grande; nasce seu segundo filho. Abandonado por sua mulher e perseguido pelos credores, deixou o Ceará e tornou-se um beato. O enfraquecimento, no século XIX, do aparelho eclesiástico beneficiou o desenvolvimento do catolicismo popular sertanejo, sustentado pelos beatos, rezadores, monges, capelães. Sem a presença do clero na 
administração dos sacramentos, abriu espaço para a atuação do beato Antônio Conselheiro. O movimento desenvolvido pelo beato foi constituído em acordo com os hábitos de uma cultura popular sertaneja, aliado a uma onda mística e religiosa. Como beato, ele era um penitente sertanejo de moral rígida, hábitos familiares, com um discurso religioso e uma prática social contestadora. Na condição de beato itinerante reúne gente para a construção de obras religiosas como edificação ou restauração de capelas, cemitérios etc. O conteúdo de suas pregações se estabelece.

Numa ordem divina que admite desigualdades e que reserva a cada um, conforme sua posição, determinados direitos e deveres. Quanto aos deserdados - aos pobres - há para eles o consolo de que, pelo caminho das privações e sofrimentos, o céu pode ser alcançado e, ao mesmo tempo, a recomendação de conformismo com a sorte, porção que Deus lhes reservou piedade filial e devotamento dos pais para com os filhos, ao lado de um rígido puritanismo, são os traços distintivos, no que se refere às recomendações sobre o trato entre gerações e entre os sexos. A lei é necessária e, com ela, os juízes e outros poderes deste mundo. (MONTEIRO, 1974, p. 65-66).

Ao seu modo, entregou-se à vida peregrina, desempenhando o papel de um exímio conselheiro dos nordestinos. Antônio Conselheiro é um líder que cumpre o papel religioso de, em nome de uma ordem divina, aperfeiçoar o comportamento dos sertanejos com suas ideias de castigo, pecado, promessa de redenção e de reconciliação. O beato lutava para preservar as virtudes tradicionais, ameaçadas pela modernidade republicana e, assim fazendo, percorreu o sertão do Ceará, de Pernambuco e de Sergipe; entrou na Bahia, tomou conta de uma fazenda abandonada. José Calasans, diz que

Além das obras das igrejas, o Conselheiro pregava aos seus fiéis, o que fazia com freqüência. Eram os "dias de conselho". Conhecedor da Bíblia, ledor da Missão Abreviada, livro de larga divulgação no interior do Brasil, o Conselheiro falava sobre os mandamentos, condenava os pecados, aconselhava para o bem, citando, não raro, frases latinas. (SILVA, 1997, p. 59, negitos do autor).

Antônio Conselheiro ganha nome nacional e internacional, pois foi personagem central do romance de Mario Vargas Llosa, La guerra del fin del mundo (1981), baseado na história do beato que virou "Conselheiro" e fundador de um movimento religioso milenarista no Brasil rural, nos fins do século XIX, Canudos (BA), pois para Ele a República é o anticristo. Monteiro diz que 
[...] é evidente que a república permanece sobre um princípio falso e dele não se pode tirar consequência legítima: sustentar o contrário seria absurdo, espantoso e singularíssimo; porque, ainda que ela trouxesse o bem para o país, por si é má, porque vai de encontro à vontade de Deus, com manifesta ofensa de sua divina lei (MONTEIRO, 1977, p. 59).

Os grandes latifundiários e poderosos ficam contra ele e veem nele o perigo à ordem estabelecida. A missão de Antônio no Arraial de Canudos alia-se ao trabalho desenvolvido por padre Ibiapina nas terras dos sertões. O beato tinha a mesma aptidão e imagem performática de missionários dos antigos capuchinhos que andavam pregando as santas missões pelas cidades e lugarejos do Nordeste; vivia como um deles: a barba grande, o hábito desbotado, sempre de sandálias; a coragem diária, o costume das missões sem nenhum conforto. Galvão diz que:

Havia dois oficios diários, à madrugada e à noitinha ou fim da tarde, e periodicamente os conselhos com data marcada, para os quais acorria gente até de longe, ansiosa por ouvir a palavra do Peregrino. Canudos assim tornou-se um centro de romaria, atraindo crentes que ali chegavam para pedir audiência e fazer doações (GALVÃO, 2001, p. 45).

O cenário da época do beato era de um catolicismo popular sertanejo herdado da cultura portuguesa. Pode-se ligar Antônio Conselheiro e padre Cícero aos protestos sociais e ao distanciamento da hierarquia eclesiástica. Suas pregações revelam ser um homem letrado e inteligente, inspiração das Missões Abreviadas e das Horas Marianas - teologia corrente na época - tratam da criação, da elevação, do castigo, do pecado, da promessa e de reconciliação com Deus.

\section{Padre Cícero}

Cícero Romão Batista ${ }^{10}$ nasceu na cidade do Crato (CE), na Rua Grande, hoje Rua Miguel Limaverde, em 24 de março de 1844. Seus país, Joaquim Romão Batista, um pequeno comerciante de tecidos e ferragens. Sua mãe, Joaquina Vicência Romana, conhecida como Dona Quinô, era dona de casa. O núcleo familiar incluía duas irmãs. Cícero foi o primogênito e único filho homem desta família de condição média (casa própria de tijolo, quatro pedaços de terra e uma mercearia). Cícero Romão Batista foi ordenado subdiácono no dia 20 de novembro e no dia 27 do mesmo mês foi ordenado diácono, sagrando-se sacerdote no dia 30 de novembro de 1870 por Dom Luís Antônio dos Santos, primeiro bispo do Ceará, (formado pelos lazaristas dentro do espírito tridentino). Em abril de 1872, assu- 
miu a função de capelão em Juazeiro do Norte (CE), onde chegara em 1871. Naquele tempo, o arraial de Juazeiro possuía cinco casas de telha e 50 de palha. Diante das necessidades pastorais que encontra em Juazeiro, decide ali permanecer com seus familiares.

O zelo pastoral de Pe. Cícero o leva a uma ação que visava orientar, organizar e moralizar com energia e rigor não apenas a vida religiosa, mas também social do lugar. Abraça a causa e começa a se impor como pregador, conselheiro e moralizador dos costumes da época, fundando em Juazeiro do Norte as Conferências Vicentinas e o Apostolado da Oração. Dedicando-se a corrigir os vícios do povo e também os abusos morais, chegando a proibir as danças, conseguiu que os homens parassem de bater nas mulheres e obrigou as prostitutas a confessar seus pecados. Com o tempo, Juazeiro passou a ser um modelo de ordem social e de virtude. Durante muito tempo padre Cícero permaneceu na pobreza. Não quis receber nada pelos sacramentos que administrava. Adquiriu fama de um sacerdote dedicado inteiramente ao povo do sertão, sempre disponível, atento, um excelente conselheiro do povo, aceitando trabalhar na capelinha mais empobrecida da diocese.

Antes de acontecer o milagre da hóstia consagrada que teria vertido sangue na boca da beata Maria de Araújo, padre Cícero já tinha fama de santo, de profeta e de milagreiro pelo povo do Nordeste. No período da "Grande Seca" de 1877-1878-1879, marcou o Nordeste e padre Cícero fez a promessa de levantar uma grande igreja, em honra do Sagrado Coração, no alto da serra do Catolé, na seguida seca de 1888. Com as chuvas as obras tiveram início, cumprindo, assim, a promessa recebida do retorno das chuvas nos sertões. Após estar estabelecido há dezessete anos em Juazeiro, padre Cícero, no dia $1^{\circ}$ de março de 1889 (foi também um ano de seca), depois de uma longa vigília noturna de oração, ao dar a comunhão para Maria de Araújo, presencia o fenômeno extraordinário do sangramento da hóstia, fato que se repete em diversas ocasiões. O milagre protagonizado pela beata Maria de Araújo, Lima sugere:

[...] quatro hipóteses para o fenômeno da "comunhão ensanguentada". A primeira é apoiada pelo "Padrim" e pelos médicos que fizeram o primeiro exame concluindo como evento de natureza miraculosa. A segunda é defendida pela igreja oficial que aponta o acontecido como fruto de superstição, fanatismo e abuso à "Santa Eucaristia". A terceira foi apresentada pelo Pe. Antônio Gomes de Araújo, e classifica o fato como um embuste patrocinado pelo Prof. José Marrocos em conivência com a beata; e finalmente le- 
vantada pelo Dr. Júlio César da Fonseca, qualificando o caso como fruto da influência do psiquismo sobre o organismo e, posteriormente, pela parapsicologia como caso de "aporte" (LIMA, 2008, p. 138).

Depois disso a sua atividade pastoral concentra-se no aconselhamento daqueles que o procuravam. Seus conselhos transpõem os limites de Juazeiro e atraem pessoas de todo Nordeste do Brasil. Sua palavra e ensinamentos penetram tanto nas casas senhoriais quanto nos casebres. Empenha-se para capacitar os sertanejos. Sua permanente busca pela readmissão no uso das sagradas ordens o leva, em 1898, a Roma, onde é autorizado a celebrar e é absolvido das sanções eclesiásticas. Seu bispo ordinário, dom Joaquim José Vieira, mantém a proibição de celebrar a missa. Nunes tem a seguinte observação:

Padre Cícero, impedido de exercer uma ação pastoral meramente sacramentaria, uma vez que estava suspenso do uso das suas ordens sacras, teve que realizar um trabalho que identificou com a ação de Ibiapina, realizando uma ação de conselheiro e padrinho lá onde se estrangulavam os angustiantes problemas da população. Há necessidade de solucionar os conflitos, de apaziguar os ânimos, de acolher tantos retirantes, de colocar jovens e adultos no campo do trabalho. Tudo isto é problema do quotidiano e as soluções devem começar aqui e não apenas na eternidade ditosa. E a estratégia de fazer de Juazeiro um lugar de oração e trabalho, fez de Juazeiro um lugar sagrado, onde se manifesta o poder de Deus não apenas nos fatos miraculosos, então, proibidos e censurados. Mas através de uma ação de aconselhamento que vê no trabalho a possibilidade de encaminhamento de muitas e muitas pessoas para uma vida mais decente, base futura de uma realidade mais abrangente. A palavra do Padre Cícero era a palavra da misericórdia de Deus: "quem matou não mate mais, quem roubou não roube mais, quem pecou não pegue mais" (NUVENS, 1994, p. 29-30).

Padre Cícero Romão Batista continua sua atuação, porém como conselheiro junto aos romeiros, em sua residência. Dentre seus inúmeros conselhos, destacamos alguns que fazem eco com a atualidade:

Não derrube o mato, nem mesmo um só pé de pau. Não toque fogo no roçado nem na caatinga. Não cace mais e deixe os bichos viverem. Plante cada dia pelo menos um pé de algaroba, de caju, de sabiá, ou outra árvore qualquer, até que o sertão seja uma mata só. Não plante serra acima, nem faça roçado em ladeira; deixe o mato protegendo a terra para que a água não arraste e não se perca sua riqueza (BARRETO, 2003, p. 44). 
Seus conselhos não perderam a validade com a distância no tempo, pois, o padre Cícero já aconselhava o povo no sentido de se preservar o meio ambiente para a sobrevivência de todos. Em suas cartas ele aconselha os fiéis: "não vá morar em terra de senhor de engenho. Não venda suas terras. Não queiram morar em terra alheia. Compre sua terra." (BARRETO, 2003, p.43). Lira Neto diz que "a exemplo dos pajés das antigas nações cariris, cujo sangue lhe corria nas veias misturado aos dos ancestrais portugueses, Cícero passara a acumular as funções de conselheiro, benzedor e curandeiro" (NETO, 2009, p.281). O padrinho, como é chamado pelos devotos, se insere dentro do contexto do compadrio, ligado às tradições populares, como observa Della Cava:

Juazeiro era, de fato, uma "cidade santa" presidida por um santo Patriarca, que era padrinho dos doentes, dos desabrigados, dos oprimidos, dos que tinham fome, dos criminosos e pecadores. Tachados de fanáticos pela sociedade culta do litoral, tais romeiros, pelo contrário, consideravam-se apenas afilhados do Padre Cícero (DELLA CAVA, 1985, p. 141).

O apadrinhamento ainda permanece como uma das principais instituições da estrutura social nordestina, de acordo com Luitgarde Oliveira, pois:

Quando alguém usa a expressão "meu padrinho", é porque identifica nesta pessoa a capacidade muito pronunciada de se responsabilizar por seus afilhados. [...] Quando alguém se dirige a outro com a expressão "meu padrinho", está-lhe rendendo ao mesmo tempo gratidão, oferecendo-lhe fidelidade, tudo isso com o significado de um título que é também de orientador, aquele que merece respeito, enfim, é um símbolo de prestação de obediência, é a escolha espontânea de alguém que merece, por sua conduta, a confiança de dirigir e aconselhar suas próprias opções de vida (BARROS, 1988, p. 173).

A relação do padre Cícero com a população do sertão não se constitui pelo mandonismo e sujeição, como era uma prática dos coronéis diante dos seus agregados. Padre Cícero ao ser nomeado de padrinho pelos romeiros é expressão do prestígio de sua atitude acolhedora e protetora dos necessitados. Faleceu na manhã de 20 de julho de 1934, com 90 anos de idade, depois de ter recebido os últimos sacramentos. Foi um acontecimento de grande comoção popular no Nordeste brasileiro. O Papa Francisco, na Audiência de 5 de setembro de 2014, assinou o documento de "reconciliação histórica da Igreja com o padre Cícero". A espiritualidade dos romeiros de padre Cícero atrai, a cada ano, aproximadamente dois milhões a Juazeiro do Norte (CE). 


\section{Frei Damião}

Nasceu no dia 5 de novembro de 1898, num vilarejo denominado Bozzano, que pertence à cidade de Massarosa, no Norte da Itália. Batizado como Pio Giannotti, mais tarde viria a ser conhecido como Frei Damião de Bozzano ${ }^{11}$. Era filho do casal de camponeses Félix e Maria Giannotti. Durante sua infância, Pio Giannotti costumava ficar em silêncio, rezando e olhando a natureza. O menino tinha o costume de conduzir sempre o crucifixo. De vez em quando ele sumia. Depois de horas, os pais iam encontrá-lo, sempre sozinho e reflexivo, no sótão da casa onde moravam. Pio Giannotti começou a estudar religião aos 12 anos, na Escola Seráfica de Camigliano. Sua vocação começava a se manifestar e, quando completou 16 anos, ingressou na Ordem dos Capuchinhos, em maio de 1914. Recebeu o hábito religioso no Convento de Vila Basílica.

Era uma época conturbada na Europa, com a eclosão da I Grande Guerra Mundial. Exatamente por conta disso, aos 19 anos ele foi convocado para servir o Exército italiano, tendo que abandonar os estudos religiosos. Atuou como soldado por mais de três anos, permanecendo alojado em Zara, zona disputada pela antiga Iugoslávia. Mostrou-se sempre um soldado sem habilidade. Portanto, depois de concluído o Serviço Militar, abandonou a farda e retornou outra vez para os estudos religiosos. Estudou na Universidade Gregoriana de Roma de 1921 a 1925. Diplomou-se em filosofia, direito canônico e teologia dogmática. Ordenouse sacerdote em 5 de agosto de 1923, aos 25 anos. Em 1925, assumiu o cargo de vice-mestre de noviços do Convento de Vila Basílica. Três anos mais tarde foi para o Convento de Massa, atuando como diretor e também como professor de jovens religiosos.

Em 1931, com 33 anos, o missionário capuchinho Frei Damião de Bozzano deixou a Itália e, após breve estadia no estado do Rio de Janeiro, rumou para o Convento da Penha, em Recife, com outros dois missionários capuchinhos. Frei Damião como missionário capuchinho percorreu todos os estados do Nordeste. Era um missionário perambulante. A sua popularidade surge pelo seu contato permanente com o povo nas pequenas cidades do interior, e também pela sua virtude pessoal. Os biógrafos constatam que há quase unanimidade de que Frei Damião é um santo para os devotos. O frade se adaptou à mentalidade rural, às práticas religiosas e à linguagem bucólica do povo nordestino.

Em todo o Nordeste, por onde passava, Frei Damião conquistava as massas. Seu carisma junto à população foi largamente usado politicamente. O frade, 
com isso, tornou-se uma figura polêmica dentro da igreja devido às acusações de permitir-se manipular por políticos nordestinos. A partir daí passou a receber críticas da hierarquia eclesiástica devido aos novos movimentos que interpelavam uma renovação pastoral para subsidiar a demanda dos movimentos dos trabalhadores urbanos e rurais. Frei Damião não acompanhou essas renovações pastorais, mesmo depois do Concílio Vaticano II, que solicitava uma catequese renovada, inclusive para as dioceses do Nordeste, em especial a de Recife, que buscou colaborar com a agenda dos movimentos sociais através do arcebispo Dom Hélder Câmara. O frade capuchinho prosseguia com as mesmas pregações conservadoras que naturalizavam as desigualdades sociais e, permanecendo assim, não tomou partido em favor dos movimentos camponeses do Nordeste.

As Ligas Camponesas de Pesqueira, em Pernambuco, revelaram um Frei Damião avesso às organizações de trabalhadores rurais. A sua indiferença com relação às Ligas tinha como justificativa que elas não eram "democráticas", mas sim um movimento de camponeses desordeiros e comunistas. Frei Damião perde a noção do mundo real e mantém-se em uma tradição religiosa conformista. Como exemplo disso, citamos excertos de uma carta enviada ao frei pelo Advogado da Liga Camponesa12:

[...] soubemos para surpresa nossa, que V. Revma. fez propaganda contra a 'Liga Camponesa', ou seja, a Associação dos Agricultores de Pesqueira [...]

E fomos informados de que V. Revma. subiu nestes dias semiúmidos de primavera de primavera a serra Urubá, transpondo caminhos acidentados para fazer sermões, embora no mesmo lugar estivéssemos falando aos agricultores, cujos caminhos cortam os latifúndios por imprudência de gente que sonhou como homens livres [...] Essa Serra, outrora pertencia aos índios, mas estes a venderam em pedaços a troco de cachaça. Habitam hoje a Serra caboclos trabalhadores que discordam dos erros dos seus antepassados, caboclos que não dispõem de terras para trabalhar porque elas foram invadidas pelos bois. Hoje, a Serra mantém uma escravidão, porém diferente da outra porque é a submissão da terra pelo boi, que vive mais bem tratado do que seres humanos que habitam aquela região conquistada pela astúcia do homem branco. [...] Foi ali que estivestes, Frei Damião, também, onde pregastes a palavra do Mestre. Mas, proferistes uma palavra diferente porque combatestes uma organização de homens que desejam melhor salário, sindicalização [...] Fazemos generoso apelo a V. Revma. para que ajude a colocar mais uma pedra sobre as pedras da obra social existente na cidade de Pesqueira, de vez que a Igreja não pode ficar ausente dessa batalha de redenção do homem da foice, do machado e da enxada. O convite está lançado e, 
como nunca será tarde demais para acertar-se com o caminho da verdade, esperam os camponeses sem terra que a V. Revma. empreste sua valorosa colaboração, pregando a REFORMA AGRÁRIA por essa imensa região do Nordeste (PEREIRA, 1969).

O posicionamento do advogado Costa Pereira evidencia que Frei Damião nas suas pregações aconselhava os trabalhadores a não participarem das Ligas Camponesas de Pesqueira $(\mathrm{PE})$, que reivindicavam por melhores condições de salários. Os sermões do capuchinho contrários às Ligas impulsionaram também os fazendeiros de Pesqueira contra a organização dos camponeses. O frade se colocou entre os membros da Igreja que viam nas transformações a ameaça à tradição católica. Contradizer essa ordem era o mesmo que se insurgir contra Deus. Daí o entendimento de que o capuchinho ratificou a fé no sobre-humano, no eterno e não no transitório da história. Em contrapartida, nas eleições presidenciais de 1989, o então candidato Fernando Collor de Mello fez comícios ao lado de frei Damião na cidade de Juazeiro do Norte (CE) e distribuiu folhinhas eleitorais com a imagem do frade. No dia 31 de maio de 1997, aos 99 anos, morre frei Damião de Bozzano. Seu corpo foi embalsamado, velado durante três dias na Basílica da Penha, no Recife. O capuchinho está sepultado na Capela de Nossa Senhora das Graças, no Convento de São Félix de Cantalice, construída especialmente para ser seu mausoléu, e hoje é ponto de visitação de romeiros. Eis aí a razão pela qual, no dia 31 de janeiro de 2003, a Ordem dos Frades Menores Capuchinhos, deram entrada no Vaticano, com o processo de Beatificação e de Canonização do Servo de Deus frei Damião de Bozzano.

\section{Considerações finais}

Ao encerrar este artigo, convém apontas algumas considerações a modo de conclusão. Em primeiro lugar, devido a escassez de pesquisas confiáveis, tornase difícil uma teoria da função do conselheiro no catolicismo popular sertanejo do Nordeste brasileiro. Dessa forma, valorizamos algumas obras que substanciam nossa pesquisa por meio de livros publicados por sociólogos, historiadores e biógrafos de cada um dos conselheiros. Fica evidenciado que a figura do conselheiro ou da conselheira parece ser típica do catolicismo sertanejo do Nordeste. Nas pequenas e médias cidades do interior, nos dias de hoje, deparamos com a presença de pequenos conselheiros e conselheiras que auxiliam as pessoas da comunidade. Porque os conselhos estão colados na memória dos sertanejos, incorporados à cultura nordestina. 
O padre Ibiapina preocupado com a morte por doenças veiculadas pela água, construía uma cisterna de captação de água de chuva em cada uma das 22 Casas de Caridade. Essas Casas eram para acolher os órfãos cujos pais tinham sido vitimadas pelo cólera ou por outras doenças. O padre Cícero Romão, influenciado por Ibiapina, foi um homem atento com as populações do seu tempo. Pouco se fala da imensa generosidade do padre Cícero em acolher as pessoas que estavam sem rumo vivendo no sertão e sem terra para trabalhar. E sem água segura para beber. Em 1888, ocorreu a libertação dos escravos e muita gente não tinha pata onde ir. Muitos acabaram indo para o Juazeiro do Norte (CE). O conselheiro Ibiapina também foi uma referência religiosa para o beato Antônio, porque este é Conselheiro consagrado pelo povo e ficou destacado por conta dos seus conselhos e pregações moralizantes.

Não se trata de uma particularidade geográfica, regional, porque em outros lugares tiveram pessoas que realizaram função análoga, como Nhá Chica ${ }^{13}$ (1808-1895), em Baependi (MG) e o monge João Maria ${ }^{14}$ na região do Contestado ${ }^{15}$ (hoje, Santa Catarina). Igualmente não se pode falar de uma característica do catolicismo, pois outras tradições religiosas também têm grande afeição por guias espirituais como o guru, o pajé, o xamã e outras pessoas que fazem alguma forma de direção espiritual.

Ao referir-se ao catolicismo sertanejo este estudo tem em mente aquela forma religiosa predominante na região semiárida do Nordeste brasileiro. Pode-se questionar, mas, em que medida a figura do conselheiro está presente - ainda que sob outras denominações - em outras formas regionais de catolicismo popular brasileiro. O conhecimento acerca do conselheiro constitui um clima extraordinário de investigação das Ciências Humanas. Pois, por intermédio delas, podese fazer um estudo de cunho sociológico, antropológico, aplicar análises pertinentes à Psicologia religiosa, explorar a dimensão histórica e a geografia religiosa, à medida que se exercita o cuidado com a Língua Portuguesa.

\section{Referências bibliográficas}

ARAÚJO, Francisco Sadoc de. Padre Ibiapina: peregrino da caridade. São Paulo: Paulinas, 1996.

AZEVEDO, Thales. O catolicismo no Brasil: um campo para a pesquisa social. Brasilia: MEC, 1955.

AZZI, Riolando. História da Igreja no Brasil: ensaio de interpretação a partir do povo: tomo II/3-2: terceira época: 1930-1964. Petrópolis: Vozes, 2008. 
BARBOSA, Francisco Salatiel de Alencar. O joaseiro celeste: tempo e paisagem na devoção ao Padre Cícero. São Paulo: Attar, 2007.

BARRETO, Francisco Murilo de Sá. Padre Cícero. $2^{\circ}$ ed. São Paulo: Loyola, 2003.

BARROS, Luitgarde Oliveira Cavalcanti. A terra da mãe de Deus. Rio de Janeiro: Francisco Alves; Brasília: INL, 1988.

BOURDIEU, Pierre. Gênese e estrutura do campo religioso.A economia das trocas simbólicas. São Paulo: Perspectiva, 1974. Cap.2.

BRAGA, Antônio Mendes da Costa. Padre Cícero: sociologia de um padre, antropologia de um santo. Bauru/São Paulo: Edusc, 2008.

BRUNEAU, T. C. Catolicismo brasileiro em época de transição. Trad. de Margarida Oliva. São Paulo: Loyola, 1974.

CERTEAU, Michel de. Cultura popular e religiosidade popular. Cadernos do CEAS,Salvador, n. 40, nov.-dez. de 1975.

COMBLIN, José. Padre Ibiapina. São Paulo: Paulinas, 1993.

COSTA, Gutemberg. Profeta do Nordeste. Natal: Clima, 1994.

CRUZ, João Everton da. Frei Damião: a figura do conselheiro no catolicismo popular do Nordeste brasileiro. (Mestrado). Belo Horizonte: Pontificia Universidade Católica de Minas Gerais, 2010.

CUNHA, Euclides da. Os sertões. $23^{\circ}$ ed. Rio de Janeiro: Livraria Francisco Alves, 1954.

DELGADO, Lucília de Almeida Neves. História oral: memória, tempo, identidades. Belo Horizonte: Autêntica, 2006.

DELLA CAVA, Ralph. Milagre em Juazeiro. Rio de Janeiro: Paz e Terra, 1985.

FREYRE, Gilberto. Casa-Grande \& senzala: formação da família brasileira sob o regime da economia patriarcal. São Paulo: Círculo do Livro, 2006.

HALBWACHS, Maurice. A memória coletiva. São Paulo: Centauro, 2004.

HERVIEU-LÉGER, Daniele. O peregrino e o convertido: a religião em movimento. Trad. de João Batista Kreuch. Petrópolis: Vozes, 2008.

HOLANDA, Sérgio Buarque de. Raízes do Brasil. 26º ed. São Paulo: Companhia das Letras, 1995.

HOORNAERT, Eduardo. A distinção entre "Lei" e "Religião" no Nordeste. Revista Eclesiástica Brasileira. Petrópolis: Vozes, v. 29, n. 3, set. de 1969. p. 580-606.

HOORNAERT, Eduardo. Formação do catolicismo brasileiro: 1550-1800. $3^{\circ} \mathrm{ed}$. Petrópolis: Vozes, 1991.

LÉVI-STRAUSS, Claude.Antropologia estrutural. Rio de Janeiro: Tempo Brasileiro, 1975.

LIMA, Antônio Carlos Ferreira. Permanência do ciclo místico-religioso na literatura de cordel e sua correção com os niveis de construção textual. Tese (Doutorado). 
Maceió: Universidade Federal de Alagoas, 2008.

LOPES, Diana Rodrigues. Padre-Mestre Ibiapina e Casa de Caridade de Triumpho - PE. Santa Cruz da Baixa: Gráfica Folha do Interior, 2004.

MENEZES, Eduardo Diatahy B. de. Pe. Ibiapina: figura matricial do catolicismo rústico do Nordeste do século XIX.Encontro Anual daANPOCS, 20, 1996. Caxambu. Anais... Caxambu, 1996.

NETO, Lira. Padre Cícero: poder, fé e guerra no sertão. São Paulo: Companhia das Letras, 2009.

NUVENS, Plácido Cidade. Tentativas de Caracterização da Romaria de Juazeiro do Norte. Seminário de 150 anos de Padre Cícero, 1994, Fortaleza/Juazeiro do Norte. Anais...Fortaleza/ Juazeiro do Norte: Editora RCV, 1994, p.25-30.

OLIVEIRA, Pedro de Assis Ribeiro de. Adeus à sociologia da religião. Religião e Sociedade. Rio de Janeiro: ISER, v. 18, n.2, 1997. p. 43-62.

OLIVEIRA, Pedro de Assis Ribeiro de. Catolicismo Popular e romanização do catolicismo brasileiro. Revista Eclesiástica Brasileira. Petrópolis: Vozes, n. 14, março de 1976. p. 131-143.

OLIVEIRA, Pedro de Assis Ribeiro de. Religião e dominação de classe: gênese, estrutura e função do catolicismo romanizado no Brasil. Petrópolis: Vozes, 1985.

OLIVEIRA, Pedro de Assis Ribeiro de. Religião e dominação de classe: o caso da "Romanização". Centro de Estatísticas Religiosas e Investigações Sociais. Rio de Janeiro: CERIS, 1980.

OLIVEIRA, Pedro de Assis Ribeiro de. Religiosidade popular na América Latina. Revista Eclesiástica Brasileira. Petrópolis: Vozes, v. 32, n.126, junho de 1972. p. 354-364.

ROLIM, Francisco. Condicionamentos sociais do catolicismo popular. Revista Eclesiástica Brasileira. Petrópolis: Vozes, v. 36, n. 141, março de 1976. p. 142170.

SANTANA, Manoel Henrique de Melo. Padre Cícero do Juazeiro: condenação e exclusão eclesial à reabilitação histórica. Maceió: EDUFAL, 2009.

SILVEIRA, Ildefonso. Estado atual da pesquisa sobre Padre Cícero. Revista Eclesiástica Brasileira. Petrópolis: Vozes, v. 36, n. 141, março de 1976. p. 226-260.

SOBREIRA, Padre Azarias. O patriarca de Juazeiro. Petrópolis: Vozes, 1969.

STEIL, Carlos Alberto. O sertão das romarias: um estudo antropológico sobre o santuário de Bom Jesus da Lapa. Petrópolis: Vozes, 1996.

TEIXEIRA, F. Faces do catolicismo brasileiro contemporâneo.TEIXEIRA, Faustino; MENEZES, Renata (org.). Catolicismo plural: dinâmicas contemporâneas. Petrópolis: Vozes, 2009. Cap. 2. p. 17-30. 
${ }_{1}$ Nasce, no dia 05 de agosto de 1806, o futuro padre Ibiapina, cearense, nascido na fazenda Morro da Jaibara, Sobral (CE). Padre secular desde 1853, foi ordenado por dom João da Purificação, com 47 anos de idade.

2 Nasce, no dia 13 de março de 1830, em Vila do Campo Maior de Quixeramobim (CE), o futuro Antônio Conselheiro, filho de Vicente Mendes Maciel e Maria Joaquina do Nascimento - de alcunha Maria Chana.

3 Nasceu no Crato (CE), no dia 24 de março de 1844, o futuro "Padrinho Cícero ou "Padim Ciço", carinhosamente chamado, precisamente na Rua Grande, hoje rua Miguel Limaverde. Filho de Joaquim Romão Batista e Joaquina Vicência Romana, a Sinhá Quinô”.

4 Foi batizado com o nome de Pio Giannotti, o futuro frei Damião, capuchinho, nascido no dia 05 de novembro de 1897 em Bozzano (Lucca), Itália, filho de Félix e Maria. Foi ordenado sacerdote em Roma, em 05 de agosto de 1923. Em 29 de setembro de 1931, ano que chegou ao Brasil, celebrou a sua primeira missão no Brasil, na Capela de São Miguel, em Gravatá (PE). Quando dom Vicente de Matos, em 1970 e em 1975, pediu a frei Damião que não pregasse mais santa missão no Crato (CE), o povo comentava: Estão proibindo frei Damião, como proibiram padre Cícero. Querem é acabar com a religião.

5 José Calasans (Silva, 1986) diz que na igreja popular sertaneja, há uma hierarquia; de beato passa a ser conselheiro. O beato podia ter uma progressão, quando ele "adquiria condições para, além disso, proferir prédicas, ou conselhos, passava a conselheiros” (Galvão, 2001, p. 33).

${ }^{6}$ No dia 17 de julho de 2008 entrevistei a Fundadora do Movimento Grupo Jesus Vive, na cidade de Nossa Senhora das Dores (SE), médio sertão, em sua residência, a professora aposentada, D. Maria Iolanda Araújo de Andrade, na época, 69 anos de idade, ela declarou-me que o "Grupo Jesus Vive nasceu a partir do Natal em família, no dia 7 de janeiro de 1985 e que se reunia semanalmente para visitar os doentes, ler a Bíblia e fazer uma Via-Sacra na Semana Santa, (procissão) rezando para chover - saindo da Igreja Matriz de Nossa Senhora das Dores (às quatro horas da manhã) com destino ao Cruzeiro do Século, na saída da cidade em direção a Serra do Machado, situado acerca de $5 \mathrm{Km}$ do centro da cidade. A manifestação teve continuidade e hoje reúne, anualmente, na sextafeira da Semana Santa, centenas de devotos em peregrinação e penitência. Atualmente a Procissão do "Cruzeiro do Século" é um espaço de devoção e Patrimônio Cultural e Imaterial do Estado de Sergipe. (Lei No 8.051 de 22 de outubro de 2015).

7 Desde a antiguidade cristã, a Confissão é chamada de "segunda tábua [de salvação] após o naufrágio da graça perdida", assim como um "segundo Batismo", ou "uma espécie de Batismo que exige compromisso" (laboriosus quidam Baptismus), conforme cita o Concílio de Trento. (GIRAUDO, Cesare. Confessar os pecados e confessar o Senhor. São Paulo: Edições Loyola, 2015, p. 7).

$8 \mathrm{Na}$ elaboração desta resumida biografia foram consultados os seguintes autores: Comblin (1993), Araújo (1996), Menezes (1996) e Lopes (2004), cujas obras constam nas referências.

$9 \mathrm{Na}$ construção desta pequena biografia consultamos os seguintes autores: Fiorim (1980), Hoornaert (1997), Benício (1997), Silva (1986 e 1997) e Galvão (2001), cujas obras estão citadas nas referências.

10 Para elaboração desta biografia foram consultados os autores: SOBREIRA (1969), Della Cava (1985), Nuvens (1994), Barreto (2003), Barbosa (2007), Braga (2008), Santana (2009), Neto (2009), Poel (2013) e Dumoulin (2017), cujas obras estão citadas nas referências.

11 Para elaboração desta breve biografia baseamo-nos: Moura (1978), Silva (1991), Oliveira (1997), Maior (1998) e Torres (2004), cujas obras estão citadas nas referências.

12 A "Carta Aberta ao Frei Damião - Grande Homem de Fé" foi escrita pelo advogado Costa Pereira, da Liga Camponesa de Pesqueira, Pernambuco, no dia 5 de novembro de 1960 e publicada no jornal "O Semanário", Rio de Janeiro.

13 Francisca de Paula de Jesus, era mestiça, filha de escrava e analfabeta, nasceu no distrito de Santo Antônio do Rio das Mortes, em São João del Rei (MG), em 1808, mas mudou para Baependi (MG) ainda criança. Com 10 anos de idade, ficou órfã da mãe. Ela nunca se casou. Atendia a todos os que procuravam e tinha sempre uma palavra de conforto, um conselho ou uma promessa de oração. Sabia dialogar, mostrando-se sábia e serena. Nhá Chica morreu no dia 14 de junho de 1895, com 87 anos de idade. Os restos mortais dela se encontram no interior do Santuário Nossa Senhora da Conceição, em Baependi. Seu processo de beatificação iniciou-se em 1993. Complementou-se em 1998. A sua causa foi assumida pela Congregação das Causas dos Santos, em 2000. 
O Papa Bento XVI, em janeiro de 2011, reconheceu a prática das virtudes cristãs, vivenciadas pela Venerável Nhá Chica. (Passarelli, 2013, p. 9-13).

14 Vale a pena informar que houve pelo menos três monges João Maria, vivendo em épocas distintas. Um cujo aparecimento remonta à década de 1850. Outro com presença marcante entre os sertanejos, aparecido na década de 1890. O terceiro aparecido na década de 1910 (Marli, 2015, p. 53).

$15 \mathrm{O}$ termo Contestado indica a região de $48.000 \mathrm{Km}^{2}$ entre a fronteira da Argentina e os rios Uruguai e Iguaçu do Peixe que foi disputada, há um século, pelos estados do Paraná e Santa Catarina. Houve conflitos armados.

Recebido em 05/07/2021

Aceito para publicação em 06/09/2021 


\title{
Contextualizações do Ensino Religioso na educação pública municipal de Juazeiro do Norte - Ceará: diálogos possiveis
}

Contextualizations of Religious Education in the municipal state education of Juazeiro do Norte (CE): possible dialogues

Rogério Paiva Castro*

Ercília Maria Braga de Olinda**

https://doi.org/10.29327/256659.12.2-13

\begin{abstract}
Resumo:
O objeto desse é artigo contextualizar a realidade do Ensino Religioso no município de Juazeiro do Norte - Ceará, com vistas à percepção de aberturas para o diálogo interreligioso nas práticas pedagógicas. Subsidiados pelo Círculo Reflexivo Biográfico como dispositivo de pesquisa na vertente qualitativa, empreendemos discussões entre os líderes pedagógicos do Ensino Religioso da Secretaria Municipal de Educação e os docentes desse componente curricular. Ficou evidenciado que a abertura para o conhecimento dos fenômenos religiosos local e universal como objetivo de aprendizagem pode contribuir para que as crianças e adolescentes estejam inseridas na proposta de formação integral que vise: uma melhor compreensão da sociedade e do mundo, o reconhecimento da liberdade de expressão religiosa e não religiosa, e a promoção e a defesa da dignidade humana.
\end{abstract}

Palavras-chave: Educação; Ensino Religioso; Educação para o Diálogo.

\section{Abstract:}

The aim of this articleis to contextualize the reality of Religious Education in Juazeiro do Norte city(CE), with a view to the perception of opening to religious dialogue in pedagogical practices. Subsidized by the Biographical Reflective Circle as a research device in the qualitative aspect,discussions between the pedagogical leaders of Religious Education fromthe Municipal Department of Education and the teachers of this curricular component have been undertaken. It has been evidenced that the opening to the knowledge of local and universal religious phenomena as a learning target can contribute to insert children and adolescents in the proposal of integral formation that aims at a better understanding of society and the world, the recognition of the freedom of religious and nonreligiousexpression, and the promotion and defense of human dignity.

Keywords: Education; Religious education; Education for Dialogue.

\footnotetext{
"Mestre em Educação pela Universidade Federal do Ceará - UFC. Professor de Língua Portuguesa e Coordenador Pedagógico na Educação Pública Municipal em Juazeiro do Norte - Ceará. Membro do Grupo de Pesquisa Dialogicidade, Formação Humana e Narrativas (DIAFHNA - CNPq/UFC). E-mail: rogeriopaivacastro@gmail.com.

** Professora aposentada da Universidade Federal do Ceará (UFC). Pesquisadora do campo das Ciências da Religião. Terapeuta holística. E-mail: erciliabragadeolinda@gmail.com
} 


\section{Introdução}

Este trabalho é decorrente de pesquisa de Mestrado Acadêmico em Educação pela Universidade Federal do Ceará (UFC), desenvolvida entre agosto de 2016 e julho de 2018, revisitada e atualizada por ocasião do V Simpósio Internacional sobre o Padre Cícero e do I Seminário de Ensino Religioso e Ciências Humanas da Secretaria Municipal de Educação de Juazeiro do Norte - Ceará, ambos realizados nesse municipio respectivamente em 2017 e 2020.

O foco da investigação foi analisar os contextos do componente curricular Ensino Religioso e suas possibilidades de abertura para o diálogo inter-religioso, sobretudo considerando o que dizem os docentes e a realidade a partir da constituição dos Planos Nacional e Municipal de Educação e da publicação da Base Nacional Comum Curricular.

O estudo foi realizado com uso de questionários padronizados e do dispositivo de pesquisa e formação denominado Círculo Reflexivo Biográfico - CRB, alternativa muito utilizada nas investigações do grupo Dialogismo, Formação Humana e Narrativas (DIAFHNA), criado em 2008 por Ercília Maria Braga de Olinda, com base nos ateliês biográficos de projetos de Christine DeloryMomberger, nos grupos reflexivos de Josso e nos Círculos de Cultura da educação popular de Paulo Freire.

$\mathrm{Na}$ primeira parte deste artigo atentamos para a realidade geral do Ensino Religioso no municipio, já trazendo as percepções dos professores deste componente curricular.

Em um segundo momento, observamos as relações entre o Plano Municipal de Educação de Juazeiro do Norte e a situação do Ensino Religioso local nas instituições públicas que ofertam o Ensino Fundamental.

Por fim, na terceira parte buscamos imprimir as percepções às possibilidades de um Ensino Religioso mediado por práticas dialógicas, amplamente defendidas entre as ideias de Paulo Freire e disseminadas por Morin e seus "pensamentos complexos”, aportes teóricos elementares desta investigação.

\section{Realidade da educação municipal e o Ensino Religioso: o que dizem os pro- fissionais envolvidos}

É perceptível que nosso caminho vai ao encontro de um novo paradigma educacional, cujo desafio é dar liberdade ao surgimento de uma ação docente em que professores e alunos podem participar e atuar ativamente no processo de aprendizagem, que se reve- 
la dinâmico, criativo, encorajador e que tem como fundamento primordial o diálogo e as descobertas individuais e coletivas. (SME/JN - Plano Municipal de Educação de Juazeiro do Norte 2015-2025. Soeiro, 2009).

Essa proposital epígrafe visa, metalinguisticamente, dar ênfase à citação que abre o Plano Municipal de Educação da cidade em questão, cujos valores semântico-educacionais estão nas possibilidades advindas dos novos paradigmas no campo da educação, a partir dos quais as ações docentes e discentes e os processos de aprendizagem possam se fundamentar primordialmente no diálogo.

Aliás, o diálogo encontra-se previsto pelos Parâmetros Curriculares Nacionais do Ensino Religioso do Fórum Nacional Permanente do Ensino Religioso, ao destacar, no item 1.3.5, que do profissional dessa área do conhecimento se espera a disponibilidade para o diálogo e a capacidade de articulá-lo a partir de questões suscitadas no processo de aprendizagem do educando, cabendo ao docente escutar, mediar conflitos, facilitar esse diálogo e ser interlocutor na relação escola e comunidade (FONAPER/PCNERs, 2009, p. 43).

É parte da razão de ser do Ensino Religioso o conhecimento e o diálogo, cabendo à escola disponibilizar o conhecimento religioso enquanto patrimônio da humanidade, tendo esse ensino como alternativa para garantir que todos os educandos tenham a possibilidade de dialogar: "Como nenhuma teoria sozinha explica completamente o processo humano, é o diálogo entre elas que possibilita construir explicações e referenciais, que escapam do uso ideológico, doutrinal ou catequético" (FONAPER/PCNERs, 2009,p. 44-45). É o que também defende a teoria freireana e suas considerações sobre a essência do diálogo como "fenômeno humano", na ação e na reflexão, como práxis, com vistas à transformação do mundo (FREIRE, 2011, p. 107). Para o filósofo patrono da educação brasileira, “ensinar exige disponibilidade para o diálogo" (IDEM, 2015, p. 132).

Em comunhão com tais intentos estão as competências gerais da educação básica da Base Nacional Comum Curricular (BRASIL, 2017, p.10): "Exercitar a empatia, o diálogo, a resolução de conflitos e a cooperação, fazendo-se respeitar e promovendo o respeito ao outro e aos direitos humanos [...]". Assim, o acolhimento, a valorização da diversidade de indivíduos e de grupos sociais, seus saberes, identidades, culturas e potencialidades, sem preconceitos de qualquer natureza, são iniciativas que se encontram previstas para os currículos no Brasil. 
Iniciando o nosso diálogo com a realidade do Ensino Religioso, contextualizemos o espaço foco: o município de Juazeiro do Norte. Localizado na microrregião do Cariri, mesorregião Sul Cearense, a população estimada em 2020 erade 276.264 habitantes, de acordo com o Instituto Brasileiro de Geografia e Estatística - IBGE (Brasil, 2020). A cidade possui o seguinte quantitativo de instituições de ensino municipais que contemplam o Ensino Religioso, de acordo com dados coletados em atuais arquivos da Secretaria Municipal de Educação em 2021: 03 Escolas de Ensino Fundamental em Tempo Integral (EEFTI); 18 Escolas que ofertam Educação Infantil e Fundamental; e 35 que oferecem o Ensino Fundamental, totalizando 53 Escolas entre as 91 instituições municipais (Prefeitura de Juazeiro do Norte, 2021).

Para os anos finais do Ensino Fundamental ( $6^{\circ}$ ao $9^{\circ}$ ano), o último concurso público municipal (também em 2019), excepcionalmente pela primeira vez, ofertou vagas específicas para o cargo de Professor de Ensino Religioso. O Edital previa que para ocupar o cargo o concorrente poderia ter Licenciatura Plena em qualquer área das ciências humanas e curso de bacharelado em Teologia (apesar de não ser formação adequada para este fim pedagógico), Ensino Religioso ou Ciências da Religião ou Licenciatura Plena em qualquer área das ciências humanas e Pós-Graduação na área do conhecimento (Teologia, Ensino Religioso ou Ciências da Religião). Com isso, pelo menos sob o viés formal, o município se aproximou de uma contratação ideal para quem lecionaria o componente curricular em análise.

Nas escolas que ofertam os anos finais do Ensino Fundamental, cada turma tem inserida no currículo uma aula semanal de 50 (cinquenta) minutos de Ensino Religioso. Embora tenha havido concurso específico para essa área do conhecimento, pelo número de vagas para contratação imediata que contemplaria média de apenas 01 docente concursado e habilitado por escola com 40 horas semanais, é provável que ainda permaneça a prática de docentes de Geografia e História completarem carga horária com Ensino Religioso em 2021.

Nesse contexto educacional, firmamos parcerias desde o ano 2015 entre a Secretaria Municipal de Educação - SME (Coordenação Pedagógica dos Anos Finais do Ensino Fundamental e do Ensino Religioso) e o Grupo de Estudos e Pesquisas sobre Religião, Mística e Espiritualidade (GERMINAR) da Universidade Federal do Ceará, coordenado pela Professora Doutora Ercília Maria Braga de 
Olinda, autora deste artigo juntamente o outro autor Rogério Paiva Castro, orientando desta por ocasião do Mestrado em Educação concluído em 2018.

Tivemos, entre diversas situações programadas da pesquisa, um encontro com os professores de Ensino Religioso dos anos finais do Ensino Fundamental do municipio. Em um momento de formação, promovido a partir dessa parceria, a Professora Ercília Olinda desenvolveu discussões em torno do seguinte tema "O Fenômeno Religioso e Formação Humana", tendo como pautas: 1. (Re)Conhecendo o Ensino Religioso no Município; 2. Palestra Interativa com o evidenciado tema; e 3. Realização de Círculo Reflexivo Biográfico, sobre o qual falamos na introdução.

Entre outras situações de contato, esta foi uma ocasião na qual pudemos realizar discussões com os docentes de Ensino Religioso sobre a realidade do componente curricular nas salas de aula do municipio em questão.

Em ocasião do dia de estudo dos professores da área de Ciências Humanas nas escolas municipais, compareceram 30 docentes. Entre estes, 16 ficaram no Círculo Reflexivo que trataria do Panorama do Ensino Religioso no Município com ênfase na Formação de Professores e no Diálogo Inter-religioso, e 14 ficaram no grupo com ênfase nas relações entre o Ensino Religioso e as religiões de matrizes africanas e entre o fenômeno religioso das romarias, que culminou com outras investigações de outros membros do grupo de pesquisa. Ao longo desse artigo daremos destaque à realidade da educação e às tendências do ensino para o diálogo inter-religioso.

Neste Círculo Reflexivo Biográfico com os Professores e a Coordenadora Municipal do componente curricular em questão, realizamos discussões dirigidas, a fim de perceber, entre as demandas do Ensino Religioso, a abertura ou fechamento ao diálogo inter-religioso nas práticas pedagógicas. Os posicionamentos destes foram considerados ao longo das nossas análises na última seção.

\section{Diálogos entre o Plano Municipal de Educação de Juazeiro do Norte e o En- sino Religioso}

Em relação às supramencionadas demandas do Ensino Religioso no município de Juazeiro do Norte, atentamos para aquilo que se encontra previsto no Plano Municipal de Educação - PME-JN 2015-2025 e que se aproxima dos propósitos desse componente curricular no cumprimento do seu papel social. 
Este documento está em consonância com o Plano Nacional de Educação 2014-2024, que tem como duas de suas dez diretrizes: a "promoção humanística, científica, cultural e tecnológica do País" (Art. 2º Inciso VII) e a "promoção dos princípios do respeito aos direitos humanos, à diversidade e à sustentabilidade socioambiental" (Art. $2^{\circ}$, Inciso X).

No campo 3 - Metas e Estratégias do Plano Municipal, elege-se como uma de suas diretrizes "difundir os princípios da equidade, do respeito à diversidade e da valorização profissional e potencializar, assegurar e incentivar a gestão democrática da Educação (PME-JN, p. 56).

Como uma das estratégias para o alcance da Meta 2 - Universalizar o Ensino Fundamental de 9 (nove anos) para toda a população de 6 (seis) e 14 (catorze) anos e garantir que pelo menos $95 \%$ dos alunos concluam essa etapa na idade recomendada, até o último ano de vigência do PME: "fortalecer o monitoramento e o acompanhamento [...] das situações de discriminação, preconceitos e violências na escola, objetivando o estabelecimento de condições para o sucesso escolar do(a)s estudantes" (idem, p. 61).

Em relação à formação de professores, o Plano Municipal de Educação de Juazeiro do Norte atenta para o Previsto no PNE, que visa garantir a todo(a)s o(a)s profissionais da educação básica a formação continuada em sua área de atuação (PME-JN, p. 21), considerando também a "formação continuada de todas as áreas e modalidades de ensino" (p. 31).

Diante desses planos, dos posicionamentos dos professores e da Coordenação Pedagógica do Ensino Religioso no Município de Juazeiro do Norte, atestamos análogas realidades já percebidas em diversos escritos que reportam sobre os desafios dessa área do conhecimento no cenário brasileiro.

A aprovação da Base Nacional Comum Curricular consolida nortes para a produção de currículos das redes que articulem os conhecimentos essenciais aos quais todos os estudantes brasileiros têm o direito de ter acesso e de se apropriar durante sua passagem pela Educação Básica. É referência para o componente curricular Ensino Religioso, que historicamente esteve em constante discussão, às vezes relegado ou não reconhecido em sua essência na prática cotidiana da escola.

O debate do Ensino Religioso é, pois, iniciativa ainda premente na atual sociedade dos discursos e práticas de negação da diversidade, da subalternização 
das crenças, saberes, identidades e culturas diferentes dos modelos socioculturalmente estabelecidos, apesar dos ativismos e das políticas de ações afirmativas.

Ratificando o dito no início desse escrito, não há dúvidas de que a educação precisa se configurar permanentemente sob novos paradigmas e perspectivas diante da pluralidade cultural brasileira. Em meio à complexidade defendida pelo epistemólogo e sociólogo Edgar Morin, precisamos passar pela reforma do pensamento que considere a unidade e a multiplicidade, a articulação das explicações de ordem sociológica, econômica, jurídica, biológica, filosófica e teológica, numa superação ao paradigma simplificador das ciências clássicas e modernas. $\mathrm{Na}$ complexidade das ciências "transclássicas" pós-modernas é possível identificar a "religação" ou a "religação do que religa", numa ideia que envolve tudo aquilo que faz comunicar, associar, fraternizar, solidarizar (MORIN, 1998, passim).

Nessas vertentes de pensamento, a diversidade cultural, religiosa e dos direitos humanos e o papel ético-político da religião trazem para o Ensino Religioso o desafio daquilo que Morin denomina "religação ética", para que promova e se defenda a dignidade humana: todo olhar sobre ética deve atentar para o ato moral enquanto "ato individual de religação"; religação com o outro, religação com a comunidade, religação com a sociedade e, no limite, religação com a espécie humana (MORIN, 2011, p. 22-23).

Se estamos inseridos no tetragrama das "forças de religação e forças de separação, forças de organização e forças de desorganização, forças de integração e forças de desintegração" (MORIN, 2011, p. 35), estamos na trágica luta da religação contra a separação, a dispersão, a morte, em meio à qual podemos desenvolver o amor e a fraternidade.

Se é função do Ensino Religioso buscar a compreensão do fenômeno religioso e favorecer o diálogo entre as religiões, é a ética um de seus fundamentos epistemológicos. A expressão do imperativo de religação para os indivíduos autônomos e responsáveis - nos ditos morinianos - é também o imperativo do Ensino Religioso.

Em meio ao "policentrismo cultural e religioso" derivado das globalizações da comunicação que afetam as crenças e as religiões (COSTELLA, 2004, p. 98), quanto mais autonomia mais os individuos devem assumir a incerteza e a inquietude e mais se tem a necessidade de religação. A consciência de que todos estamos perdidos no universo deve nos conduzir à consciência de que "mais temos 
a necessidade de nos religarmos com os nossos irmãos e irmãs da humanidade" (MORIN, 2011, p. 36).

\section{Educação pública municipal: perspectivas para o diálogo inter-religioso}

A proposta pedagógica de Ensino Religioso do município de Juazeiro do Norte explicita, na exposição quanto à concepção desse ensino como componente curricular, o "pressuposto" de contribuir para a formação de pessoas, tendo como uma de suas intencionalidades a busca de qualidade de vida em sociedade.

Como contraposição à sociedade de exclusão permeada pelos preconceitos e pela alienação, propõe-se a "leitura dialética da realidade" como possibilidade de compreender os elementos contraditórios, a diversidade de relações e os elementos de unidade possiveis para a construção de uma sociedade justa, fraterna, igualitária, solidária, digna, em que o respeito ao princípio de liberdade seja considerado como busca e decisão coletiva. (Secretaria Municipal de Educação, entre 2009 e 2015, p.2).

Nessa proposta há a convicção de que a releitura do fenômeno religioso e de suas mudanças é possivel pela análise dialética das relações sociais, na busca pela compreensão dos processos sociais e culturais. Há a ideia do direito de os indivíduos professarem uma fé, "enquanto fenômeno religioso ou não, em diferentes tradições religiosas, como forma de construírem uma identidade pessoal e coletiva", prevendo também, no respeito pela vida, "o estabelecimento de uma ordem de prioridades e de organização da prática do bem comum", através da "transmissão de valores", do "desenvolvimento de atitudes, do alargamento da consciência a respeito de direitos e deveres para consigo e para com os demais" (idem, p. 3).

Amparada na Resolução 404/2005 do Conselho Estadual de Educação do Ceará $^{1}$, a proposta pedagógica do Ensino Religioso da Secretaria Municipal de Educação de Juazeiro do Norte (após 2015, até 2020, o que se apresentou como proposta de currículo foi o previsto na Base Nacional Comum Curricular) preconizava a definição dos conteúdos da programação do componente, visando: o subsídio ao aluno na compreensão do fenômeno religioso, presente nas diversas culturas e sistematizado por todas as tradições religiosas; a articulação do conhecimento religioso com os demais conhecimentos que integram a formação do cidadão; a indução ao respeito à diversidade; a promoção da prática de atitudes respeitosas em relação ao outro e à natureza; o incentivo à fraternidade e à soli- 
dariedade na convivência social; o despertar, nos alunos, do interesse pelos valores humanos; e a orientação para uma formação harmonizadora dos aspectos somáticos, emocionais e espirituais do educando.

Se para a Secretaria Municipal de Educação é relevante que "o diálogo inter-religioso seja impulsionado pelo desejo de um melhor entendimento humano, vindo a contribuir para uma melhor 'confiabilidade' [sic] humana"2; se se concebe que "a escola com a qual se sonha" deve promover o diálogo inter-religioso; se se atenta para "a tensão formada entre vivência religiosa dos docentes, a complexidade cultural e religiosa brasileira e os aspectos teórico-científicos atinentes ao estudo do fenômeno religioso e a dimensão do sagrado no cotidiano"; e se a Secretaria acredita que a efetivação dos preceitos legais do Ensino Religioso e de suas diretrizes "depende de valores interligados", como a "mudança de atitude dos profissionais da escola para que o diálogo inter-religioso seja uma realidade, o que implica, não apenas tolerar a opção do outro, mas reconhecer seu direito à livre orientação religiosa"; então percebemos que há abertura para, por exemplo, inserir a busca pelos conhecimentos atinentes ao fenômenos religiosos diversos entre os estudos dessa área do conhecimento.

Analisando a possivel abertura para o diálogo ao considerar o exemplo das romarias como fenômeno religioso, alguns professores relataram considerar tal temática em sua prática pedagógica no componente curricular Ensino Religioso, outros no componente Estudos Regionais, que é da parte diversificada do currículo municipal.

Ainda, houve quem se posicionou contrário, por considerar que, se trabalhar o referido assunto, estaria direcionando sua ação para uma "determinada religião". Elucidamos, no entanto, que tal abordagem atenderia ao objetivo da área do conhecimento em questão, por propiciar o conhecimento dos elementos básicos que compõem o fenômeno religioso percebido no contexto dos educandos, além de constituir-se apenas o estudo de um fenômeno, entre tantos outros que precisam ser abordados em sala de aula.

Em relação à prevalência do catolicismo no contexto juazeirense, houve a ideia de que esse direcionamento religioso sobrepõe a imagem do Padre Cícero (em detrimento de outras possibilidades) e que a escola e os estudantes ainda estão "relutantes" quanto à não abertura para diferentes formas de religiosidade.

A maioria, todavia, se posicionou e justificou como não sendo um empecilho para a viabilização do diálogo inter-religioso. Essas convergências e divergên- 
cias, entre aquilo que impediria ou mediaria o diálogo entre as religiões, reconfirma o paradigma da complexidade moriniano, quando lembra que cada um vive para si e para o outro de maneira dialógica, complementar e antagonicamente, associ-adoao egoísmo, mas com potencialidades fundamentais para o desenvolvimento do altruísmo (MORIN, 2011, p. 20).

Quando Morin diz que "todo olhar sobre ética deve levar em consideração que a sua exigência é vivida subjetivamente" (Id.), ele situa a fé na ética como semelhante ao aspecto místico, que parece emanar de uma "injunção sagrada". Nos tempos modernos, em que "a ética já não tem mais fundamento exterior", firma-se a fé na própria ética, cabendo não eliminar nem o componente racional nem o componente místico do universalismo ético: vale a fé na liberdade, fé na igualdade, fé na fraternidade.

Se se acredita que "a universalização da ética para todo o ser humano, seja qual for a sua identidade, só começará com as grandes religiões transculturais como budismo, cristianismo, islamismo", mesmo reconhecendo que "esse universalismo permanecerá limitado, com lacunas, frágil e será incessantemente acuado pelos fanatismos religiosos e pelos etnocentrismos nacionais", resta, em tempos de deslocamentos da relação trinária indivíduo/sociedade/espécie, o suscitar de uma ética metacomunitária em favor de todo ser humano (MORIN, 2011, p. 24).

Em tempos de crise dos fundamentos da ética e de individualismos éticos, crê-se que a área do conhecimento Ensino Religioso pode mediar a noção de que "a ética exige o pluralismo enquanto distanciamento de si mesmo e abertura ao outro" (HERMANN, 2001, p. 96) e de que "vivemos em um mundo reconhecidamente plural que traz a exigência de educar aceitando o outro em sua alteridade" (HERMANN, p. 133).

O fato de os docentes pesquisados considerarem suas práticas pedagógicas como mediadoras do diálogo inter-religioso é algo que, apesar das variáveis a se considerar nos discursos e nas próprias práticas, se torna fato alvissareiro na perspectiva de superação dos limites da relação educação e religião na comunidade una e ao mesmo tempo plural, como se houvesse indícios de valorização da diferença e vislumbres de disposição para a tolerância.

Esse posicionamento, entre os outros, parece comungar com o pensamento exposto pelo Papa Francisco na ocasião da plenária do Pontificio Conselho pa- 
ra o Diálogo Inter-religioso ${ }^{3}$, quando mencionou só existir um caminho para derrotar o medo: "é o caminho do diálogo e do encontro caracterizado pela amizade e pelo respeito". Dialogar, lembrou o pontífice "não significa renunciar a própria identi-dade, quando vamos ao encontro do outro, e não significa ceder a comprometimentos a respeito da fé e da moral cristã" (FRANCISCO, 2013, p. 138). E completa:

O futuro encontra-se na convivência respeitosa das diversidades, não na homologação a um pensamento único, teoricamente neutral. Vimos durante muito tempo na história a tragédia dos pensamentos únicos. Por isso, torna-se imprescindivel o reconhecimento do direito fundamental à liberdade religiosa, em todas as dimensões (FRANCISCO, 2013, p. 138).

A exortação de Bergoglio à Igreja de nada impor, de não recorrer a qualquer estratégia dissimulada para atrair fiéis, mas testemunhar com alegria e simplicidade "aquilo em que cremos e o que nós mesmos somos" é um convite a assumir a própria identidade e reciprocamente respeitar a identidade do outro. $\mathrm{O}$ diálogo construtivo entre pessoas de diferentes tradições religiosas, assevera o líder religioso, ajuda a também superar outro tipo de medo, que infelizmente aumenta nas sociedades que ele diz mais incisivamente secularizadas: "o receio em relação às diversas tradições religiosas e à dimensão religiosa enquanto tal" (FRANCISCO, 2013, p. 138).

Quando "as fontes da ética quase não irrigam mais", quando "a fonte individual é asfixiada pelo egocentrismo", quando "a fonte comunitária é desidratada pela degradação da solidariedade" quando "a fonte social é alterada pela compartimentação, burocratização, atomização da realidade social” e é atingida por diversos tipos de corrupção, quando "a fonte bioantropológica é enfraquecida pelo primado do indivíduo sobre a espécie” humana (Morin, 2011, p 28), é quando vemos a coerência do pensamento do Papa Francisco ainda no aludido discurso.

Esse é o tempo em que, segundo o referido pontífice,"a religião é considerada inútil, ou até perigosa" (FRANCISCO, 2013, p. 138). Como quem denuncia que em nome da demanda universalista têm-se eliminado a diferença e o particular, Bergoglio imprime sua percepção: "É comum o pensamento segundo o qual a convivência só seria possível, ocultando a própria pertença religiosa, encontrando-nos numa espécie de espaço neutro, desprovido de referências à transcendência”. (idem). 
No entanto, o líder religioso questiona: "como seria possivel criar relações autênticas, construir uma sociedade que seja verdadeira casa comum, impondo que se deixe de lado aquilo que cada um considera como uma parte intima do próprio ser?" Em resposta, afirma: "Não é possivel pensar numa fraternidade 'de laboratório". Indubitavelmente, segundo ele "é necessário que tudo se verifique no respeito das convicções do outro, até de quantos não acreditam, mas devemos ter a coragem e a paciência de irmos uns ao encontro dos outros, por aquilo que nós somos" (idem).

Em consonância com esses pensamentos, o Ensino Religioso enquanto área do conhecimento deve vir para confirmar que a religião (em seu sentido pleno, vinculada àquilo que a mantém viva, - a fonte espiritual), entre outros antigos fundamentos comunitários nacionais e étnicos que trazem "segurança psíquica e religação ética" (MORIN, 2011, p. 28) pode, sim, ser manifestada, estudada, vivida e compreendida enquanto direito humano.

A atitude pela qual o ser humano se sente ligado ao todo, como fio condutor que liga e re-liga todas as coisas, com o qual pode dialogar e entrar em comunhão com ele (a fonte originária de todas as coisas, o Mistério do Mundo ou simplesmente Deus) - Espiritualidade - e a forma de ser e de sentir que acolhe e interioriza experiencialmente esse Mistério, permitindo que ele impregne toda a existência - a Mística - são "experiências seminais que movem a vida humana e dão força aos imperativos éticos” (BOFF, 2003, p. 102), e que precisam ser consideradas na educação religiosa de proposta laica.

A despeito das diferenças doutrinais e dos múltiplos caminhos espirituais, Boff (2003, p. 105-106) lembra que as religiões convergem em alguns pontos decisivos para o "ethos mundial", os quais são, citando Hans Küng: "o cuidado com a vida"; o "comportamento ético elementar"; a "justa medida"; a "centralidade do amor"; as "figuras éticas exemplares"; a "definição de um sentido derradeiro", o sentido do todo e do ser humano; elementos estes que trazem reservas éticas.

Assim, o Ensino Religioso em Juazeiro do Norte, que parcialmente revelou considerar as romarias como exemplo de fenômeno religioso em sua prática pedagógica, aduz ação que pode facilitar "a compreensão das formas que exprimem o Transcendente na superação da finitude humana e que determinam, subjacentemente, o processo histórico da humanidade" (FONAPER/PCNERs, p. 46), inclu- 
sive por esse caso de valorização das experiências religiosas percebidas no contexto dos educandos.

A espiritualidade, concebida por Boff (2003, p. 9) como "uma das fontes primordiais, embora não seja a única, de inspiração do novo, da esperança alvissareira, de geração de sentido pleno da capacidade de autotranscendência do ser humano" é algo vivamente perceptivel no contexto das romarias, por isso, não devendo ser assunto vilipendiado do processo no Ensino Religioso local. Como demais fenômenos religiosos de dimensão cristã, de matrizes africanas, entre outros.

A educação, que requer uma reforma programática, mas mais ainda paradigmática, precisa ir além dos saberes "desunidos, divididos, compartimentados" e das realidades "ou problemas cada vez mais multidisciplinares, transversais, multidimensionais, transnacionais, globais e planetários” (MORIN, 2000, p. 36).

\section{Considerações finais}

As formações inicial e continuada e a disposição de material didático adequado consistem em elementos indispensáveis no contexto do Ensino Religioso, todavia, é inegável que nele prepondera a necessidade da "espiritualidade", sendo esta aquilo que produz em nós uma mudança e sendo ela o possível sentido encontrado pelo próprio docente em sua predisposição à postura de abertura para melhores práticas, que contribuam para que ele mesmo e os educandos se tornem pessoas melhores.

É esse sentido que complementa e indispensavelmente pode viabilizar mudanças maiores na prática docente, que permitam que os educadores: adequadamente utilizem habilidades, métodos e técnicas pedagógicas necessários para a construção e a reconstrução do conhecimento religioso pelos educandos; reconheçam, respeitem e valorizem a diversidade e a complexidade das manifestações e experiências religiosas no contexto escolar e social, além dos princípios históricos, culturais, filosóficos, éticos, doutrinais e morais das diferentes matrizes religiosas; analisem o papel das tradições religiosas na estruturação e na manutenção das suas respectivas realidades sociais, históricas, políticas e culturais; e coletivamente busquem respostas para os seus questionamentos existen- 
ciais, no entendimento da sua(s) identidade(s) religiosa(s) ou arreligiosas e na convivência com as diferenças.

Além disso, transformações que permitam aos docentes a interpretação do fenômeno religioso na diversidade cultural local e global, com diferentes leituras, através das diversas áreas de conhecimento; o aprofundamento contínuo de seus conhecimentos; a atuação ética e comprometida, objetivando a constituição de uma sociedade justa, solidária e humana, questionando e buscando intervir nas fontes geradoras do sofrimento, da ignorância, da injustiça e da ausência de paz.

Torna-se consensual afirmar que a ética da alteridade deve ser um dos fundamentos epistemológicos e pedagógicos para a viabilização do diálogo interreligioso e intercultural, princípio basilar para o reconhecimento da diversidade cultural na perspectiva da totalidade da vida. Infelizmente ainda há situações escolares onde não se estabelece o diálogo inter-religioso. Felizmente o Ensino Religioso existe e é esperança e ocasião pedagógica oportuna para a desnaturalização das discriminações e preconceitos entre grupos humanos, orientada a seguir o caminho de reconhecimento das identidades culturais religiosas e não religiosas e ir ao encontro da convivência respeitosa e de posturas altruísticas de valorização do outro, tendo a convicção político-pedagógica paulo-freireana de que as ações dialógicas e as mudanças são atos possiveis.

\section{Referências Bibliográficas}

BOFF, Leonardo. Ethos mundial um consenso mínimo entre os humanos. Rio de Janeiro: Sextante, 2003.

BOFF, Leonardo. A convivialidade necessária para a humanidade não perecer. Jornal O Tempo - Belo Horizonte, publicado em 14/12/12 - Opinião. Disponível em http://www.otempo.com.br/opini\%C3\%A3o/leonardo-boff/a-convivialidadenecess\%C3\%A1ria-para-a-humanidade-n\%C3\%A3o-perecer-1.736. Acesso em 11 de abrilde 2021.

BRASIL. IBGE - Instituto Brasileiro de Geografia e Estatística. Ceará - Juazeiro do Norte. Disponivel em: https://cidades.ibge.gov.br/brasil/ce/juazeiro-donorte/panorama. Acesso em 10 de abril de 2021.

BRASIL. Lei $n^{\circ}$ 13.005, de 25 de Junho de 2014. Aprova: Plano Nacional de Educação - PNEe dá outras providências. Disponivel em http://www.planalto.gov.br/ccivil_03/_ato2011-2014/2014/lei/113005.htm.

Acesso em 11 de abril de 2021. 
BRASIL. Base Nacional Comum Curricular - Disponivel em http://basenacionalcomum.mec.gov.br/images/BNCC_EI_EF_110518_versaofina 1_site.pdf. Acesso em 10 de abril de 2021.

COSTELLA, Domênico. O fundamento epistemológico do Ensino Religioso. JUNQUEIRA, Sérgio; WAGNER, Raul (org.). O Ensino Religioso no Brasil. Curitiba: Champgnat, 2004.

FONAPER. Fórum Nacional Permanente do Ensino Religioso. Parâmetros Curriculares Nacionais - Ensino Religioso. $9^{\circ}$ ed. São Paulo: Mundo Mirim, 2009.

FREIRE, Paulo. Pedagogia do Oprimido. Rio de Janeiro: Paz e Terra, 2011.

FREIRE, Paulo. Pedagogia da Autonomia. São Paulo: Paz e Terra, 2015.

MORIN, Edgar. O Método 6 - Ética. Porto Alegre: Sulina, 2011.

MORIN, Edgar. A Ética do Sujeito Responsável. CARVALHO Edgar de Assis (et. al.) (org.). Ética, solidariedade e complexidade. São Paulo: Palas Athena, 1998.

MORIN, Edgar. Os sete saberes necessários à educação do futuro.Trad.de Catarina Eleonora F. da Silva e Jeanne Sawaya. $2^{\circ}$ ed. São Paulo: Cortez; Brasília: UNESCO, 2000.

PAPA FRANCISCO. Discurso do Papa Francisco aos participantes da plenária do Pontificio Conselho para o Diálogo Inter-Religioso. CNBB - Comissão Episcopal para o Ecumenismo e o Diálogo Inter-Religioso. Revista Brasileira de Diálogo Ecumênico e Inter-Religioso. Documentação,ano 02, n. 02, jan.-julho de 2014. p. 137-138.

PMJN - PREFEITURA MUNICIPAL DE JUAZEIRO DO NORTE, CEARÁ.Plano Municipal de Educação. Prefeitura Municipal. Secretaria Municipal de Educação. Conselho Municipal de Educação. Impresso. Juazeiro do Norte: PMJN, SEDUC, CME, 2015.

SME. Secretaria de Educação de Juazeiro do Norte - Ceará. Proposta Pedagógica de Ensino Religioso. Material impresso. Juazeiro do Norte, 200_.

SOEIRO, Kelma Araújo. Currículo e Formação de Professores: Construção Coletiva Dialogada. SAMPAIO, Mariza Narciso (org). Práticas de Educação de Jovens e Adultos/complexidades, Desafios e propostas. Belo horizonte: Autêntica, 2009. (Coleção estudos em EJA).

\footnotetext{
${ }^{1}$ A Resolução dispõe sobre o componente curricular Ensino Religioso a ser ministrada no ensino fundamental, nas escolas da rede pública do Sistema de Ensino do Estado do Ceará, e dá outras providências.

${ }^{2}$ A Proposta Pedagógica do Ensino Religioso da SME cita Berkenbrock (1996, p.327), embora não conste nas referências desta. "A atitude franciscana no diálogo inter-religioso"
} 
do teólogo Volney José Berkenbrock, professor do programa de pós-graduação em Ciência da Religião da Universidade Federal de Juiz de Fora - MG, encontra-se emMoreira, 1996. Onde se vê "confiabilidade" leia-se "convivialidade". Acerca deste termo, verBoff, Leonardo. A convivialidade necessária para a humanidade não perecer (consta nas referências).

3Disponível emRevista Caminhos de Diálogo - Pluralismo Religioso: Horizontes abertos. Publicação extra da Revista Brasileira de Diálogo Ecumênico e Inter-religioso da Conferência Nacional dos Bispos do Brasil). Consta nas referências como esta última.

Recebido em 08/08/2021

Aceito para publicação em 26/09/2021 


\section{Breve historiografia do gênero musical missa no Brasil e as três missas nordestinas do movimento armorial}

Brief historiography of the Mass musical genre in Brazil and the three northeastern Masses of the armorial movement

\section{Resumo:}

O presente artigo é parte de uma pesquisa maior que visa mapear as missas compostas fora dos ambientes eclesiásticos. O texto apresenta uma breve historiografia do gênero no Brasil a partir dos esforços de inculturação pós-Vaticano II sem a pretensão de oferecer um estado da arte completo, mas com o intento de divulgar e informar a pesquisadores/as interessados/as no assunto, especialmente liturgistas, músicos e pastoralistas, a grande fecundidade da cultura brasileira e seu potencial de resistência à globalização gospel que atinge também certos setores do catolicismo brasileiro com os "padres cantores". O artigo apresenta também um panorama do Movimento Armorial e destaca três missas compostas por autores ligados a esse movimento.

Palavras-chave: Missas brasileiras. Música nordestina. Movimento Armorial. Cultura nordestina.

\section{Abstract:}

This article is part of a larger research aimed at mapping the Masses composed outside ecclesiastical environments. The text undertakes a brief historiography of such genre in Brazil based on some post-Vatican II inculturation efforts without the intention of offering a state of the art, but rather, with the intention of disseminating and informing researchers interested in the subject, especially liturgists, musicians and pastoralists, about the great fertility of Brazilian culture and its potential to resist the globalized trend of "gospel praise", which also affects certain sectors of Brazilian Catholicism with the "singing Fathers". The article also presents an overview of the Armorial Movement and highlights three Masses composed by authors linked to this movement.

Keywords: Brazilian Masses;Brazilian Northeastern music; Armorial Movement;Brazilian Northeastern culture.

\footnotetext{
*Bacharel em Teologia (Seminário Teológico de Londrina - 1990) e pela Faculdade Unidade de Vitória (2014), Mestrado (1994) e Doutorado (1998) em Ciências da Religião (UMESP). Professor no Núcleo de Graduação em Clências da Religião e no Programa de Pós-Graduação em Ciências da Religião da UFS. E-mail: cecalvani@hotmail.com
} 


\title{
Introdução:
}

\author{
"A fé vem pelo ouvir" \\ (Apóstolo Paulo - Romanos 10.17)
}

O presente artigo é parte de uma pesquisa maior, de mapeamento de missas musicadas na contemporaneidade principalmente fora da tutela eclesiástica. A título de esclarecimento, lembro que o termo "missa" pode ser compreendido em dois sentidos: (a) o religioso stricto sensu (eclesiástico, teológico e dogmático) que compreende a missa como o culto principal da Igreja, com suas partes fixas e móveis; e (b) o estético (não-eclesiástico) no qual "missa" é um gênero próprio da música que se utiliza das partes fixas da missa eclesiástica com bastante liberdade, inclusive textual. Portanto, a expressão "missa", atualmente pode ser compreendida a partir dessas duas óticas: a religiosa e a estética.

O presente texto tem caráter informativo, na medida em que pretende divulgar três missas nordestinas compostas por autores vinculados ao Movimento Armorial, e pouco conhecidas por músicos, musicistas e liturgistas mais jovens.

\section{Missa: da função eclesiástica ao gênero musical}

O gênero "missa" nasceu no ambiente eclesiástico, mas atualmente se emancipou do mesmo. Contudo, tal emancipação não é radical, pois alguns músicos eventualmente compõem missas com funções litúrgicas, enquanto outros utilizam o texto do missal para experimentações musicais, na contramão de um tem-po em que a Igreja subordinava a linguagem musical a seus interesses. Se antes a música servia ao texto litúrgico, atualmente, é o texto da missa que serve às experimentações musicais. Desde a Idade Média, mas sobretudo no final do século XVII, a junção do texto litúrgico com a linguagem musical se desenvolve em prol da valorização da própria música e tudo o que a compõe (melodia, harmonia, ritmo) e as particularidades internas de cada uma dessas instâncias. $\mathrm{Na}$ modernidade, o texto da missa se descola e se desloca de seu contexto religioso, e por extensão "decola", ganhando forma própria, independente de ser autorizada ou não por alguma autoridade eclesiástica.

Não nos interessam aqui os detalhes rituais e teológicos da missa eclesiástica, propriamente, mas o gênero musical "missa". Um gênero musical pode ser identificado a partir de um conjunto de elementos estruturais que o compõem e 
que aproximam pessoas que reconhecem aquele conjunto como dotado de uma forma própria. Nesse caso propomos que o gênero "missa" comporta:

(a) a utilização da sequência tradicional da missa eclesiástica (Kyrie, Gloria, Credo, Sanctus/Benedictus/Hosana, Agnus Dei). A essa sequência podem ser introduzidas outras partes do rito;

(b) a predominância do latim (à exceção do Kyrie, sempre em grego, e de expressões hebraicas e aramaicas como Aleluia, Hosana e Amém); ultimamente, porém, sobretudo após o Vaticano II, há grande profusão de missas em outros idiomas;

(c) a adaptação métrica do texto à melodia de modo que possa ser cantado por solistas ou coro;

(d) uma identidade autoral, que lhe dá o caráter de obra completa, composta por uma pessoa que registra a partitura, ou por mais de uma, que registram a obra (é o caso da Missa dos Quilombos). Ou seja, a missa musicada tem uma identidade estética própria e às vezes também um conceito formal (valorização de uma etnia, de uma cultura minoritária ou um protesto político).

Ao privilegiar o "gênero musical missa", estamos seguindo pegadas abertas por Max Weber nos ensaios "Rejeições religiosas do mundo e suas direções" (Weber, 1982) e "Fundamentos racionais e sociológicos da música" (Weber, 1995).

Em linhas gerais, Weber observa que, no Ocidente a música passou por um processo de racionalização de tal apuro técnico que se tornou autônoma em relação à sua antiga subserviência à religião, e capaz inclusive de concorrer substutivamente com a mesma, porque

todas as religiões sublimadas da salvação focalizaram apenas o
significado, e não a forma, das coisas e atos para a salvação [e] des-
valorizaram a forma como contingente, como algo da criatura e que
a afastava do significado" (...) A arte assume a função de uma sal-
vação neste mundo, não importa como isto possa ser interpretado.
Proporciona uma salvação das rotinas da vida cotidiana, e especi-
almente das crescentes pressões do racionalismo teórico e prático.
(...). Aos olhos da religião, essa salvação é um reino de indulgência
irresponsável e um amor secreto (WEBER, 1982, p. 391).

Leopoldo Waizbort, tradutor e responsável pela "Introdução" da edição brasileira de "Os fundamentos racionais e sociológicos da música", esclarece:

Com o processo de racionalização e a conseqüente autonomização da arte, esta passa a possuir valores próprios, que acabam por competir com os valores da religião. Quanto mais autonomizada for 
a arte, maior será sua tensão com a religião, pois sua legalidade própria a desatrela do religioso. Assim está instituída a relação de tensão entre a esfera estética e a esfera religiosa. No estado atual do processo de racionalização - a modernidade -, tal tensão chegou a um ponto extremo, já que a arte assume a função de uma forma de redenção, papel que a religião reserva para si (e que a economia e a politica, por exemplo, usualmente não reclamam) (WAIZBORT in WEBER, 1995, p. 31).

Por extensão, assumimos nesse texto a perspectiva de que o processo de autonomia da música, sobretudo após o período das reformas eclesiásticas no Ocidente deflagrou inevitáveis tensões com a Igreja Católica Romana, principalmente no que diz respeito ao interesse de compositores por musicar o texto da missa eclesiástica. Apegada a formas antigas, a Igreja inicialmente não acompanhou tais desdobramentos e muitos compositores, cerceados em sua liberdade criativa pelos padrões autorizados de "música sacra", promoveram um movimento oposto. Já não devendo satisfações à Igreja, nem temendo ameaças de excomunhão, trouxeram as palavras da missa para o âmbito de domínio geral da música. A relação, portanto, se inverteu: agora o texto da liturgia é que serve à música, e não o oposto (a música como serva da liturgia). Se nem todas as novas formas de música contemporânea são consideradas "sacras" pela Igreja, nem por isso deixam de ser música "religiosa".

O desenvolvimento das artes musicais e o incentivo à música na reforma protestante (Deutsche messe e o Saltério de Genebra) levou o Concílio de Trento a promulgar em 1562 o Decretum de observandis et evitandis in celebrationeMissaeque proibiu a utilização de melodias "sedutoras e impuras", bem como o uso de instrumentos associados à música "mundana”, autorizando somente o órgão como suave base harmônica. A partir de 1570 o Missal prescreve o emprego exclusivo do latim, a sucessão de partes fixas (Ordinário), os trechos que variam de acordo com o calendário litúrgico (Próprios), as que seriam cantadas pelo oficiante (bispo, padre ou diácono) e as que eram permitidas ao coro. Enfim, seja no catolicismo ou nas igrejas reformadas, a música strictu sensu sempre foi considerada "serva" da palavra, uma auxiliar a serviço do texto litúrgico ou da mensagem proclamada, o que de certo modo limitava experimentos musicais. Quanto mais próxima a vigilância institucional, maior também a vigilância dogmática e, consequente, menores as possibilidades de criatividade artística. São muitos os documentos oficiais da Igreja impondo limites e cerceamentos à produção musical de missas. Interessados podem consultar Tralesollecitudine, Papa Pio X, 
1903; Constituição Apostólica DivinisCultusSanctitatem, Papa Pio XI, 1928 e Encíclica MusicaeSacrae Disciplina, do Papa Pio XII, 1955.

Em todas as declarações oficiais da Igreja, prevaleceu durante muito tempo a mesma atitude e o mesmo adjetivo: a música deve ser "serva" da liturgia. A despeito disso, na modernidade, gradativamente os compositores perceberam que a música oferece oportunidade para múltiplas formas de expressão capazes de superar as restrições eclesiásticas e ganhar autonomia a partir de seus próprios valores internos, deixando de ser apenas um instrumento a serviço da ética religiosa, do dogma ou da instituição.

Esse processo de apuro das técnicas musicais colaborou para que alguns compositores se arriscassem a experimentações musicais com o texto, mas sem preocupações litúrgicas. Assim, ocorre uma inversão: se até então, muitos compositores obedeciam às expectativas eclesiásticas, compondo músicas "a serviço do texto litúrgico", agora é o texto litúrgico que serve como base e plataforma para o exercício de novas técnicas de composição e arranjo. É o caso de três famosas missas que, a despeito do grande reconhecimento que adquiriram nos círculos musicais, não têm qualquer intenção de serem aproveitadas como "missas litúrgicas" executadas durante um oficio religioso: a "Grande Missa em Dó menor, K 427" (Mozart), a "Grande Missa em Si menor BWV 232" (Bach) e a "Missa Solemnis Opus 123" (Beethoven). Essas obras ajudaram no processo de autonomização do gênero missa, pelo "deslocamento" da função litúrgica, abrindo espaço para descolamentos posteriores, como a "Grande missa de Réquiem opus 05" (Berlioz), a "Missa Canônica em Dó Maior” (Brahms).

\section{Missas musicadas ${ }^{1}$ no Brasil - breve historiografia}

As primeiras missas musicadas no Brasil são da época colonial, seguem padrões do barroco e do classicismo e refletem certa tensão entre influências das escolas italianas e germânicas. Medeiros (2014) considera que principais são a Missa Brevis de André Silva Gomes (1852-1844) em estilo rococó, para vozes e instrumentos, a "Grande Missa em Mi Bemol" e a "Missa em Fá", ambas do mineiro José Joaquim Lobo de Mesquita (1764-1805).

Já no Brasil-Império, a principal referência genuinamente brasileira é o padre José Maurício Nunes Garcia (1767-1830), filho de escrava alforriada e conhecido como "padre mulato". Reconhecendo seu talento, Dom João VI o nomeou 
mestre e organista da Capela Real, o mais alto cargo para um músico na época. Porém, a transferência progressiva de músicos ligados à antiga corte em Lisboa muito o prejudicou, pois constantemente tentavam afastá-lo, por racismo e inveja, alegando que naquele posto não deveria encontrar-se alguém "com defeito físico visível”, em alusão à sua ascendência negra. Não há espaço aqui para comentar suas principais missas - a "Missa de Nossa Senhora da Conceição" (1810), a "Missa Pastoril para a noite de Natal" (1811), a "Missa de Requiem" (1816), a "Missa de Nossa Senhora do Carmo" (1818) e a "Missa de Santa Cecília" (1826), mas desde que Mário de Andrade o considerou "o primeiro nome ilustre da música brasileira” (ANDRADE, 1980, p. 173), seu legado tem sido recuperado e valorizado através de diversas pesquisas, dissertações e teses (MATTOS, 1970; FIGUEIREDO, 2000; GOLDBERG, 2004: AFFONSO, 2005; COTTA, 2008; VIRMOND e NOGUEIRA, 2011; D'ACOL, 2015). Todas essas obras podem ser ouvidas no youtube ou em outras plataformas de streaming em gravações de coro e orquestra nacionais e internacionais

Ainda no Brasil Imperial, Francisco Manuel (1795-1865), compositor do Hino Nacional Brasileiro, compôs a "Missa em Mi Bemol" e Carlos Gomes (18361896), antes da ópera "O Guarani" (1870), compôs ao menos duas missas: a "Missa de São Sebastião" (1854) e a "Missa de Nossa Senhora da Conceição" (1859).

A Semana de Arte Moderna (1922) inspirou compositores a pesquisar ritmos e melodias "folclóricas" a fim de identificar elementos que apontassem para a construção de uma "brasilidade". Villa Lobos, Camargo Guarnieri e GuerraPeixe adotaram forte viés nacionalista, mas também dialogaram criativamente com tendências e experimentos dodecafônicos e atonais. Alguns atenderam às regras eclesiásticas (Osvaldo Lacerda, p.ex), enquanto outros se serviram do texto litúrgico para novas experimentações sonoras.

Após o Vaticano II as regras eclesiásticas se flexibilizaram bastante, dando oportunidade ao surgimento de missas em diversos idiomas. Antes mesmo do Vaticano II, o padre franciscano Guido Haazen criou no antigo Congo a "Missa luba" (1958) e no mesmo ano, no Brasil, Reginaldo Carvalho (ex-aluno do grupo nacionalista de Villa-Lobos) concebeu a "Missa Sertaneja" com diferentes ritmos nordestinos e letra em português com um texto coloquial ("a gente" em lugar de "nós" no Kyrie e no Agnus Dei e "CrenDeusPai" no Credo). Em 1964 Ariel Rami- 
rez criou a MisaCriolana Argentina. Tais expressões motivaram compositores brasileiros a voltar compor missas utilizando elementos da cultura popular. No anexo deste artigo, são elencadas algumas missas surgidas no Brasil no século XX. Dessa grande profusão criativa, algumas merecem breves comentários:

Em 1971, o maestro Carlos Alberto Pinto Fonseca compôs a "Missa Brasileira de Batuque e Acalanto" para coro e solistas. O texto utiliza latim e português e vários ritmos diferentes não necessariamente identificados com a "cultura afro" (marcha-rancho, vira-português, samba-canção e aboio). O Credo reproduz cantigas de roda folclóricas como "Tutu Marambá" e "Se esta rua fosse minha". Porém, sua recepção em outros campos foi prejudicada pelo fato de o próprio maestro declarar ser uma composição "técnica", concebida quando morou em Salvador, mas que ele mesmo, jamais frequentou qualquer culto afro, faltandolhe a percepção de que o modo de tocar os instrumentos no batuque ritual, bem como o idioma (ioruba, banto, etc) revelam a identidade do grupo (Nagô, AngolaCongo). Além disso, o modo de tocar os instrumentos no batuque, bem como o idioma (ioruba, banto etc) revela as hierarquias e os orixás invocados. Tais fatores levaram Fernandes (2004, p. 63) a considerar que essa missa, "muito mais do que resultado de um sincretismo religioso, é produto de uma estética nacionalista”.

Esse questionamento certamente está ligado ao título referencial dado à obra, pois o ouvinte não-iniciado em técnicas musicais e mais interessado nas influências culturais, espera exatamente o que a Missa, em sua partitura original, não apresenta: "não existem referências a orixás ou a melodias tradicionalmente associadas ao culto afro. A performance da obra não requer coreografias ou movimentos que lembrem as danças características de tais rituais" (FERNANDES, 2004, p. 62). A despeito disso, trata-se de obra de inegável qualidade musical, muito elogiada e bem recebida nos ambientes da música erudita. Em 2006 o percussionista Djalma Fonseca acrescentou notações para percussão e a missa foi gravada pelo Coro que leva o nome do compositor, com adequada percussão. ${ }^{2}$

Bem diferente esteticamente é a "Missa dos Quilombos" (1981), uma das mais emblemáticas produzidas no Brasil. Concebida entre setores do clero católico progressista, foi musicada por Milton Nascimento resultando em produto híbrido - é, ao mesmo tempo, missa e espetáculo performático. Enquanto missa stricto sensu, foi celebrada pela $1^{\mathrm{a}}$ vez no Quilombo da Serra da Barriga em Ala- 
goas e na semana seguinte na Praça do Carmo, na cidade do Recife, no local onde a cabeça de Zumbi dos Palmares foi exposta em 1695. A repercussão chamou a atenção da Sagrada Congregação para o Culto Divino e os Ritos, e o Vaticano proibiu sua celebração por quase uma década. Enquanto espetáculo, foi apresentada em 1989 nos Arcos da Lapa no Rio de Janeiro e 1992 em Santiago de Compostela, a convite da Prefeitura, como parte das "comemorações" dos 500 anos de colonização da América Latina. Em 2002 o grupo Cia Espaço Aberto montou espetáculo próprio com coreografias. Em 1995 voltou a ser celebrada como missa eclesiástica no Santuário Nacional de Nossa Senhora de Aparecida em São Paulo.

Compositores brasileiros têm sido muito criativos na produção de missas, algumas "inculturadas" (valorizando elementos de uma cultura ou região) outras "ecléticas" (combinando vários elementos). Não há espaço aqui para considerar a riqueza dessa produção. Apenas é possivel indicar algumas composições expressivas, mas pouco conhecidas fora dos ambientes de música erudita:

O compositor baiano Lindembergue Cardoso (1939-1989) deixou vasta obra musical. Feitosa (2010) analisou essa produção à luz do Concílio Vaticano II destacando, ao mesmo tempo a religiosidade e a heterodoxia no uso dos sistemas musicais. O pesquisador catalogou 110 peças. Dentre essa vasta produção destacam-se "Kyrie-Christi" (1971), "Os Atabaques de Pombagira” (1974), para coro misto a cappella, a Cantata natalina "Oxaguian" (1975) eaópera Lídia de Oxum (1988), para oito vozes solistas, coro e orquestra, estreada em 1995 sob a batuta do Maestro Júlio Medaglia em Salvador, além de seis missas. O envolvimento do compositor com a Igreja Católica levou a Arquidiocese de Salvador a convidá-lo a compor a "Missa João Paulo II na Bahia" (1980) com elementos da cultura musical do Nordeste, percussão de atabaques e agogô e coro de 672 vozes que acompanhou a missa oficiada pelo Papa em 07/07/1980 na capital baiana.

Jean Kleeb é natural de Santo André (SP) e radicado na Alemanha. Sua "Missa Brasileira" para coral e orquestra é eclética: Kyrie em ritmo de bossa- nova com muitas dissonâncias, suave percussão e influências jazzísticas ${ }^{3}$. O Gloria em latim é entoado em ritmo de samba e baião. Segue-se o Laudamus-te, ária operística acompanhada por viola de gamba. Indianische, um ritmo indigena, acompanha oGracias e o Domine Deus e a viola de gamba retorna junto a um címbalo no Quitollispeccatamundi, seguido pelo Quonian em ritmo de maracatu. O Credo inicia de modo tradicional, com influências do romantismo e, aos poucos 
sambaliza-se, terminando suavemente. O Sanctus é em ritmo de jazz (Takt 5/4) e os ritmos brasileiros voltam em profusão no Benedictus mesclando baião, maracatu e uma ária clássica. A Missa se encerra com o Agnus Dei, em acalanto. Obra de grande qualidade e que acompanha a proposta eclética e em alguns momentos "antropofágica" do compositor, tal como definida em seu próprio site - "uma ponte entre a música coral europeia e a intensidade rítmica da América do Sul".

KilzaSetti, musicóloga e Doutora em Antropologia Social (USP), foi aluna de Camargo Guarnieri (escola nacionalista). Atualmente trabalha como etnomusicóloga, desenvolvendo pesquisas sobre repertório caiçara, sistemas musicais de derivação africana e dos índios Mbyá-Guarany e música ritual do povo Timbira do Maranhão e Tocantins. A "Missa Caiçara" foi composta em 1990, por solicitação da Prefeitura de Peruíbe (SP). Mescla o texto em latim como pano de fundo, sobreposto pelo texto da missa em português, resultando em uma espécie de "tradução simultânea". A Missa foi concebida para ser executada dentro do ofício católico por coro e instrumentistas, mas a autora não encontrou nas igrejas da região músicos tecnicamente preparados para executá-la, embora a considere extremamente simples. Por fim, a estreia só veio a ocorrer em 1996 no II Festival de Música Sacra de São Paulo, com regência do maestro Samuel Kerr. Uma análise dessa obra, com entrevistas e partituras pode ser encontrada em Ribalta (2011).

\section{O Movimento Armorial e as Três missas nordestinas}

O Movimento Armorial surgiu em 1970 sob a liderança de Ariano Suassuna na condição de mentor estético, a partir de uma exposição de artes plásticas na Igreja de São Pedro dos Clérigos e um concerto com a Orquestra Armorial de Câmara. Ganhou apoio e adesão de artistas e escritores da região Nordeste do Brasil e da UFPE (Universidade Federal de Pernambuco) através do Departamento de Extensão Cultural da Pró-Reitoria para Assuntos Comunitários, da Prefeitura do Recife e da Secretaria de Educação e Cultura do Estado de Pernambuco. O objetivo era incentivar uma arte brasileira erudita (música, dança, literatura, artes plásticas, teatro, cinema e arquitetura) a partir das raízes populares do Brasil. Suassuna incomodava-se com os sinais do que hoje chamamos "globalização" e que na época era chamado "imperialismo cultural" (a invasão avassaladora da cultura "pop", especialmente norte-americana). O termo "armorial" aponta para o conjunto e o brilho de insígnias, estandartes, bandeiras e brasões de 
um povo, como as que vemos ainda hoje nas festas populares nordestinas. Conforme Suassuna,

\begin{abstract}
Comecei a dizer que tal poema ou tal estandarte de Cavalhada era 'armorial', isto é, brilhava em esmaltes puros, festivos, nítidos, metálicos e coloridos, como uma bandeira, um brasão ou um toque de clarim. Lembrei-me, aí, também, das pedras armoriais dos portões e frontadas do barroco brasileiro,e passei a estender o nome à escultura com a qual sonhava para o Nordeste. Descobri que o nome 'armorial' servia ainda para qualificar os 'cantares' do Romanceiro, os toques de viola e rabeca dos Cantadores - toques ásperos, arcaicos, acerados como gumes de faca-de-ponta, lembrando o clavicórdio e a viola-de-arco da nossa Música barroca do século XVIII (SUASSUNA, 1974, p. 9).
\end{abstract}

Além disso, Suassuna insista que a identidade do movimento derivava de sua localização espacial ou geográfica - o Nordeste - especialmente o rural, o sertão e a zona do agreste. O mentor esclarece outros elementos:

\begin{abstract}
A Arte Armorial Brasileira é aquela que tem como traço comum principal a ligação com o espírito mágico dos "folhetos" do Romanceiro Popular do Nordeste (Literatura de Cordel), com a Música de viola, rabeca ou pífano que acompanha seus "cantares", e com a xilogravura que ilustra suas capas, assim como com o espírito e a forma das Artes e espetáculos populares com esse mesmo Romanceiro relacionados (SUASSUNA, 1974, p. 4).
\end{abstract}

Medeiros (2014, p.52) observa a grande importância conferida pelo movimento à literatura de cordel e aos folhetos do romanceiro popular nordestino, com destaque para a xilogravura, o mamulengo (teatro de bonecos), os "autos" populares encenados ao ar livre "com personagens míticas, cantos, roupagens principescas feitas a partir de farrapos, animais misteriosos como o boi, o "pavão misterioso" e o cavalo-marinho do bumba-meu-boi. Na dramaturgia buscava um estilo de figurino e encenação tipicamente nordestinos tal como no "Auto da Compadecida".

Na música erudita, a principal referência do movimento foi Guerra-Peixe (1914-1993) que, desde os anos 50, já radicado no Recife, abandonou o dodecafonismo, passou a estudar ritmos nordestinos (maracatu, aboio, coco, frevo, xangô, baião, xote, xaxado, martelo-agalopado, etc.) e influenciou toda uma geração de novos compositores que foram seus alunos e revalorizam o pífano, a viola sertaneja, a guitarra ibérica, a rabeca e o marimbau. Além disso, os músicos "armoriais" empreenderam projetos acadêmicos de pesquisa documental e de campo, catalogando e identificando particularidades e origens desses ritmos e formas de cantar que rementem ao Brasil-Colônia. Conforme Queiroz, 
a música armorial é, portanto, uma música erudita, composta a partir de nossas raizes musicais arcaicas, tal como se acham preservadas no folclore nordestino. Tal como a música nordestina em geral, a música armorial é marcada por algumas constantes típicas, como a linguagem harmônica modal (uma reminiscência do cantochão trazido pelos missionários no Brasil Colônia), a presença da quarta aumentada e da sétima abaixada na linha melódica e os ritmos sincopados do coco e do baião, além de outros. Como se vê, não se pode dizer que o armorial representa o início de uma linguagem musical nordestina, já que ele constrói a sua música em cima de uma linguagem já existente no cancioneiro popular. $\mathrm{O}$ que ele representa é o início de uma linguagem musical erudita, que resgata as nossas verdadeiras raizes nordestinas (QUEIROZ, 2010, p. 16).

Todo movimento, caso não se institucionalize acaba por se dissipar a partir do falecimento de seus líderes. O mesmo aconteceu com o Movimento Armorial. Porém, essa "dissipação" não foi mera pulverização, mas polinização, uma vez que vários compositores nordestinos absorveram elementos "armoriais" em suas músicas e letras (o cearense Ednardo, os aboios do baiano Elomar, o Quinteto Violado, o Quinteto Armorial, o paraibano Zé Ramalho, o pernambucano Alceu Valença etc) e na literatura fantástica e/ou de cordel (o paraibano Jessier Quirino). No que se refere a "missas", o destaque maior é para as três principais obras que apresentamos a seguir:

\section{A Grande Missa Nordestina (Clóvis Pereira)}

O pernambucanoClóvis Pereira (1932-) foi aluno de Guerra-Peixe. Detalhes da biografia e entrevista com o compositor podem ser encontrados na pesquisa de Bezerra (2014). Envolveu-se com o Movimento Armorial já em 1970, a convite de Suassuna e declarou em entrevista recente: "Eu assisti junto com ele, caboclinhos, maracatus e outras manifestações do nosso folclore, e fui ficando impregnado dessa coisa de Nordeste e desviei o curso que eu tinha pra busca de música americana” (apud BEZERRA, 2014, p. 10).

A Missa Nordestina (1977) foi composta durante um semestre letivo por solicitação da UFPB (Universidade Federal da Paraíba), onde o compositor lecionava desde 1964 e ganhou reconhecimento internacional. Utiliza texto em latim e é escrita para coro, solistas (tenor e soprano) e Orquestra de Câmara (cordas, quinteto de madeiras e percussão). Após a primeira apresentação no teatro da 
UFPB, foi adaptada para Orquestra Sinfônica a pedido do BANORTE (Banco Nacional do Norte), que financiou também a gravação em estúdio, com um coral de 100 (cem) vozes, trompas, dois trompetes, dois trombones, uma tuba e um octavino. O álbum foi lançado com o título "Grande Missa Nordestina"4.

A música mescla diferentes ritmos nordestinos, tradição e contemporaneidade. O Kyrie e o Gloria trazem fortes influências gregorianas e alternâncias entre coro feminino, masculino, misto e solistas e no Gloria é marcante a introdução do terno de pífanos, ganzá e triângulo ao ritmo de baião. O Credo combina gregoriano e reminiscências de aboio, um modo lamentoso e lastimoso de tanger o gado, entoado por vaqueiros sertanejos. Para alguns pesquisadores da cultura popular, esse estilo é uma típica influência moura (CASCUDO, 2001, p.35) e que muito recorda as preces vespertinas islâmicas. O Benedictus é um típico acalanto, terno e introspectivo. Já no Agnus Dei são marcantes os traços de aboio lamentoso e da chamada "cantiga de cego", presente também ao final do Gloria.

\section{Missa de Alcaçus - Danilo Guanaes}

Composta em 1996 para solistas, coro e orquestra a pedido do Madrigal da Escola de Música da UFRN (Universidade Federal do Rio Grande do Norte) pelo prof. Danilo Guanaes (UFRN), a obra também adere à estética do Movimento Armorial. Embora seja paulistano, o maestro Danilo César Guanaes cresceu em Natal, onde foi aluno de Clóvis Pereira e onde também se graduou em Música na UFRN.

A Missa segue o texto em latim e as partes fixas do Ordinário e se caracteriza pela utilização de diferentes estilos medievais (cantilenas portuguesas, modinhas e acalantos). Os elementos populares estão presentes principalmente nas escalas e ritmos de aboio, baião, caboclinho, maracatu, repente e na orquestração com profusão de instrumentos tipicamente identificados com o interior nordestino, além de batuques africanos. Estreou no próprio ano de 1996 e, desde então, foi executada várias vezes por diferentes grupos orquestrais no Brasil e na Europa. O título da Missa remete ao povoado de Alcaçus, distrito de Nísia Floresta, na região metropolitana de Natal (RN), onde o autor desenvolveu pesquisas de campo junto a mulheres rendeiras e identificou muitas memórias populares de romanceiros ibéricos medievais bem como as influências do canto mouro. 
O Kyrie se inicia com um toque convidativo de viola respondido por violinos, com triângulo e zabumba que marcam o ritmo do coro. A percussão do Gloria lembra uma cavalgada. O Credo inicia com um canto lamentoso, típico das procissões populares nordestinas e adquire tons ora festivos, ora aboísticos mesclados com gregoriano e influências mozartianas no Deus de Deo. O contraste entre a sobriedade lamentosa do Crucifixus e a alegria do Et Ressuxit são de grande significação teológica. A obra tem também uma peculiaridade: a depender dos arranjos, pode se tornar uma Missa Brevis, pois os trechos do Ordinário são curtos (embora exijam muita técnica por parte de sopranos e barítonos) o que pode ser de muito aproveitamento para liturgistas. O registro da gravação pelo Madrigal da Escola de Música da UFRN pode ser acessado em https://www.youtube.com/watch?v=VJh3EqfwEOE com arranjos muito cuidadosos. Uma análise sociológica da obra pode ser encontrada em Medeiros (2014), que também oferece informações biográficas sobre o autor e outros detalhes de sua produção musical.

\section{A Missa Armorial (Lourenço F. Barbosa - "Capiba")}

Capiba (1904-1997) foi um dos mais conhecidos compositores de frevos de Pernambuco e um dos criadores do famoso bloco "Galo da madrugada", mas sempre esteve aberto a outros estilos. Compôs "Maria Bethãnia", gravada por Nelson Gonçalves, fundou um trio com Hermeto Pascoal e Sivuca e uma banda de jazz acadêmica. Aderiu ao Movimento Armorial e colaborou com o mesmo através de várias peças músicas como "Toada e Desafio", a suite "Sem lei nem rei", a "Missa Armorial" e trilhas sonoras para teatro.

Composta em 1982, a missa tem estilo camerístico, utilizando cordas, duo de flautas e percussão pé-de-serra (zambumba, caixa e triângulo). Nesse sentido, distancia-se do estilo orquestral de Clóvis Pereira. Também utiliza o texto em latim e, com exceção do Benedictus, é sustentada por ritmos ligados ao forró nordestino (baião, xote e xaxado) com toques de frevo. Embora o título seja "Missa Armorial", a gravação do álbum com coro e a Orquestra Armorial regidos por Cussy de Almeida, levou o nome "Grande Missa Armorial" (https://www.youtube.com/watch?v=fI9S_iHyv3Y).

Os elementos tipicamente nordestinos são identificados logo no Kyrie em ritmo de xaxado. O Gloria, mais contido, é uma toada e seu primeiro compasso 
lembra as "cantigas de cego", transformando-se em baião com toques operísticos no solo barítono e posteriormente assumindo o tom lamentoso dos aboios. $\mathrm{O}$ Credo se inicia com diálogo entre solistas e coro e se desenvolve em ritmo de xote, cantiga de roda, toada de aboio e finaliza com baião, reunindo diversos elementos em torno de uma mesma confissão de fé. O Sancuts em baião é seguido por um suave Benedictus com inspirações bachianas. Uma mescla de baião e xaxado lembrando um forró nordestino finalizam a obra no Agnus Dei.

\section{Considerações finais}

Não é intenção deste texto sugerir músicas para atrair pessoas para a Igreja. O objetivo é valorizar elementos da cultura musical nordestina que, em qualquer igreja que leve a sério os sentidos teológicos atribuídos à palavra "inculturação" também devem ser considerados. Além disso, fazer sugestões litúrgicas é um atrevimento que pode cair em generalizações, pois a liturgia é um ato da comunidade de fé, e tudo o que for sugerido depende das condições próprias das comunidades (músicos, instrumentos adequados, solistas, coral, etc.). Ou seja, sempre há o risco de idealizar situações que jamais seriam reais em certas comunidades. Por outro lado, é preciso reconhecer que as comunidades eclesiásticas são grandes celeiros musicais, e que muitos músicos, cantores e cantoras no Brasil e em outros países descobriram e aprimoraram seus dons e talentos tocando e cantando em igrejas, e esse potencial não pode ser menosprezado.

Um estudo sobre missas "inculturadas" também pode trazer um grande desafio: perguntar-se o motivo pelo qual viramos as costas à imensa riqueza musical de nossas culturas regionais e às nossas raízes musicais ("arcaicas", diriam os armoriais). KilzaSetti, Jean Kleeb, Lindembergue Cardoso e os compositores armoriais, longe de se envergonhar dessas raízes "arcaicas", as tomaram como fonte de inspiração musical e se abriram a registros e estruturas que, embora não veiculadas nas grandes mídias, permanecem latentes e dormentes na memória musical de muita gente. Faltam-nos ainda "missas" pantaneiras, gauchescas, amazonenses, ribeirinhas etc, o que também colaboraria na resistência à globalização cultural imposta pelo capitalismo, o mercado fonográfico e a Indústria Cultural. Também é preciso estar atentos para o fato de que povos-vizinhos e irmãos já nos oferecem obras de grande qualidade (a MisaCriolla, a Misa Guarany, a Misa por Buenos Aires, a Missa equatoriana, a Missa Cubana de Pedro Triana e a Missa guatemalteca). 
Esse, porém, não é um problema somente musical, mas cultural. Os/as músicos/musicistas continuarão compondo, às vezes em inter-relação com as igrejas, outras vezes, de modo autônomo, sem preocupações mercadológicas ou propriamente eclesiásticas. Afinal, "toda boa dádiva e todo dom perfeito vêm do alto" (Tiago 1.17), e, ao receber esses dons e talentos, realizam a seu modo e à sua "forma" e estilo, o que a escritura cristã chama de "multiforme" graça de Deus: "Cada um viva conforme a graça recebida a serviço dos outros, como bons administradores das muitas formas da graça que Deus lhes concedeu" (I Pedro 4.10).

\section{Referências Bibliográficas}

ADORNO, Theodor.Introdução à Sociologia da Música: doze preleções teóricas. Trad.de Fernando Moraes Barros. São Paulo: Editora Unesp, 2011.

AFFONSO, Rodrigo Cardoso. Um Estudo sobre a Relação Texto-Música: os Ofícios Fúnebres de José Mauricio Nunes Garcia. Dissertação (Mestrado em Música). Rio de Janeiro: UNIRIO, 2005.

ALMEIDA, Ágata Yozhiyoka. Música, religião e morte: recorrências tópicas na Missa de Réquiem em mi bemol maior de Marcos Portugal. Dissertação (Mestrado em Música). São Paulo:Universidade de São Paulo, 2016.

ANDRADE, Mário de.Pequena história da música. $8^{\circ}$ ed. Belo Horizonte: Editora Itatiaia Limitada, 1980.

BEZERRA, José Renato Accioly. Grande Missa Nordestina de Clóvis Pereira: estudo para interpretação. Dissertação (Mestrado em Música). Natal: Universidade Federal do Rio Grande do Norte, 2014.

CAMPOS, Beatriz. Letra, música, performance e memória do racismo na Missa dos Quilombos. Dissertação (Mestrado em Literatura e práticas sociais). Brasília: UnB, 2017.

CANTON, Ciro. Das "velhas senzalas" às "novas favelas": a Missa dos Quilombos. Anais do XXV Simpósio Nacional de História. Fortaleza: ANPUH, 2009.

CASCUDO, Câmara. Mouros, Franceses e Judeus: três presenças no Brasil. $3^{\circ}$ ed. São Paulo:Global, 2001.

COTTA, André Guerra. Notas preliminares sobre o cantochão acompanhado na prática musical luso-brasileira dos séculos XVIII e XIX: o Hino a São João Batista de José Maurício Nunes Garcia. Per Musi.Belo Horizonte: UFMG, n. 18, jul.dez. de 2008.

DUARTE. Maria Dolores Pires do Rio. Travessia: a vida de Milton Nascimento. Rio de Janeiro: Record, 2006. 
FEITOSA, Marcos A. R. A Missa brevis de Lindembergue Cardoso: uma análise à luz do Concílio Vaticano II. Anais do XV Colóquio do Programa de Pós-Graduação em Música da UNIRIO. Rio de Janeiro, 2010.

FIGUEIREDO, Carlos Alberto. Editar José Maurício Nunes Garcia. Tese (Doutorado em Música). Rio de Janeiro: UNIRIO, 2000.

D'ACOL, MitiaGanade. Decoro musical e esquemas galantes: um estudo de caso das seções de canto solo das missas de Réquiem de José Maurício Nunes Garcia e Marcos Portugal. Dissertação (Mestrado em Música). São Paulo: Universidade de São Paulo, 2015.

FERNANDES, Angelo José. Missa afro-brasileira de batuque e acalanto: aspectos interpretativos.Dissertação (Mestrado em Música). Campinas: UNICAMP, 2004.

GARCIA, Luís Henrique e PÚBLIO, Hudson Leonardo. (Re)percussões da Missa dos Quilombos. Orfeu. Florianópolis: UDESC, vol. 3, n. 2, dez. de 2018. p.164188.

GOLDBERG, Luis Guilherme. Alberto Nepomuceno e a Missa de Santa Cecília de José Maurício Nunes Garcia. Anais do VI Encontro de Musicologia Histórica. Juiz de Fora, 2004.

GUIMARÃES, Raquel Junqueira. A liturgia do corpo negro na Missa dos Quilombos. Verbo de Minas. Juiz de Fora, vol. 18, n.32, agosto-dezembro de 2017. p. 7995.

MATTOS, Cleofe Person de. José Maurício Nunes Garcia: Biografia. Rio de Janeiro: Biblioteca Nacional, 1997.

MEDEIROS, Ana Judite de Oliveira. Missa de Alcaçus: aproximações melódicas com os romances medievais ibéricos. Dissertação (Mestrado em Ciências Sociais). Natal: Universidade Federal do Rio Grande do Norte, 2014.

MINAMI, Edison. Milton Nascimento e o diálogo inter-religioso na Missa dos Quilombos. Conhecimento \& Diversidade. Niterói: UFF, n. 1, jan.-jun. de 2009. p. 110-122.

OLIVEIRA, Augutos Marcos F. Exxodos e encruzilhadas na Missa dos Quilomobos. Tese (Doutorado em Antropologia Social). Florianópolis: Universidade Federal de Santa Catarina, 2015.

OLIVEIRA, Rosenilton. Orixás: a manifestação cultural de Deus: uma análise das liturgias católicas 'inculturadas"'. Dissertação (Mestrado em Antropologia Social). São Paulo: Universidade de São Paulo, 2008.

QUEIROZ, Rucker Bezerra. O Movimento Armorial em três tempos: aspectos da música nordestina na contextualização dos Quintetos Armorial, da Paraíba e Uirapuru. Tese (Doutorado em Música). Campinas: Universidade Estadual de Campinas, 2014.

RIBALTA, José Luís C. Missa Caiçara: uma abordagem analitico-interpretativa da obra de KilzaSetti. Dissertação (Mestrado em Música). São Paulo: USP, 2011, 2 volumes. 
SILVA, Vladmir. Aspectos estilísticos do repertório coral na obra de Reginaldo Carvalho. Música Hodie. Goiânia: UFG, vol. 9, 2001.

SUASSUNA, Ariano. O Movimento Armorial. Recife. Editora Universitária da UFPE, 1974.

TEIXEIRA, Selma S. Missa dos Quilombos: um canto de Axé. Revista de Letras. Curitiba: UTFPR, v. 1, n. 2, 1997.

VIRMOND, M. C. L.; NOGUEIRA, L. W. M. VeniSancteSpiritus: um moteto de José Maurício Nunes Garcia. Per Musi. Belo Horizonte: UFMG, n.24, 2011.

WAIZBORT, Leopold. Introdução In: WEBER, Max; Fundamentos racionais e sociológicos da música. Trad. deLeopoldo Waizbort. São Paulo: EDUSP, 1995.

WEBER, Max. Fundamentos Racionais e Sociológicos da Música. Trad. Leopoldo Waizbort. São Paulo: EDUSP, 1995.

WEBER, Max. Ensaios de Sociologia. Rio de Janeiro: Guanabara Koogan, 1982.

WEBER, Max. Rejeições Religiosas do Mundo e Suas Direções. In: Ensaios de Sociologia, Ed. Guanabara, Rio de Janeiro, 1982. 


\section{Anexo \\ Algumas missas brasileiras compostas no século $\mathbf{X X}$}

(Muitas poderão ser localizadas por pesquisadores/as no youtube ou em outras plataformas de streaming)

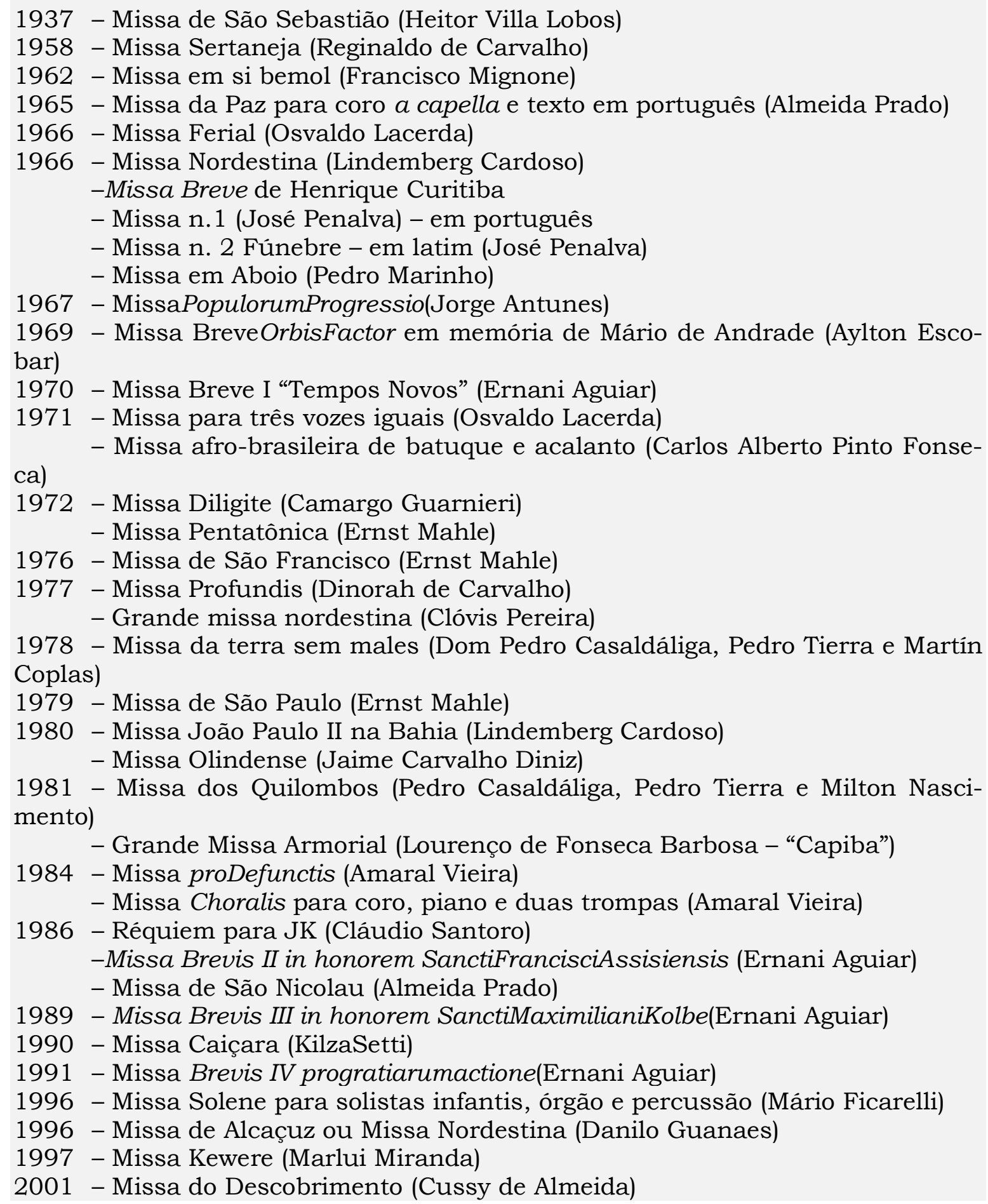


2003 - Missa in Memorian de Arthur Bispo do Rosário (Arrigo Barnabé)

2007 - Missa in Memorian de Itamar Assumpção (Arrigo Barnabé)

2019 - Missa Nóia - os infernos da Cracolândia (Arrigo Barnabé)

Por ser a mais recente, indicamos link Podcast abaixo onde podem ser ouvidos (somente solidtas e coro), sem instrumentação, o Kyrie, Gloria, Santuse Agnus Dei:https:/ / podcastosesp.podbean.com/?s=Missa+N\%C3\%B3ia

\footnotetext{
1 Optamos por "musicadas" ao invés de "musicalizada", pois essa segunda expressão diz respeito mais propriamente ao processo de iniciação e aprendizado das técnicas musicais.

2 Gravação completa em https://www.youtube.com/watch?v=LTA7rNo-SVU. Acesso em 19 de junho de 2021.

3 Sugestão de audição: https://www.youtube.com/watch?v=NC190-mD2MQ.Acesso em 19 de junho de 2021.

4 Sugestão de audição:https://www.youtube.com/watch?v=1USkS1_YOCE. Acesso em 19 de junho de 2021.
}

Recebido em 19/06/2021

Aceito para publicação em 24/07/2021 


\title{
Religião e poder estatal no Brasil: da Colônia à República
}

Religion and state power in Brazil: from the Colony to the Republic

\author{
David Mesquiati de Oliveira* \\ Leila Miranda Damasceno** \\ Lucia Maria Roriz Verissimo Portela ${ }^{* * *}$ \\ Robson Prati Neves de Oliveira ${ }^{* * * *}$ \\ https://doi.org/10.29327/256659.12.2-15
}

Resumo:

O objetivo do artigo é pontuar como se deu a relação entre o poder estatal e a religião nas Constituições brasileiras, desde o período colonial até a Constituição Federal de 1988. A relação Igreja e Estado não ocorreu uniformemente no Brasil. Ao contrário, as várias Constituições nacionais mantiveram vínculos e criaram rupturas entre uma Constituição e outra, sustentando a tensão entre os ideais separatistas e os confessionais na relação Igreja e Estado. A primeira seção trata do conceito abrangente de religião e sua relação com a sociedade, a partir de Durkheim e Eliade. A segunda, retomará o conceito de poder estatal a partir da teoria geral do Estado, de Hobbes e Rousseau. A terceira e última seção, analisará a relação entre religião e Estado brasileiro a partir das suas Constituições federais ao longo da história do Brasil.

Palavras-Chave: Religião. Estado. Direito. Laicidade.

\section{Abstract:}

The aim of thisarticle is to point out how the relationship between State power and religion occurred in the Brazilian Constitutions, from the colonial period up to the 1988 Federal Constitution. The relationship between Church and State did not occur uniformly in Brazil. On the contrary, the various national Constitutions maintained links and created ruptures between one Constitution and another, sustaining the tension between separatist and confessional ideals in the relationship between Church and State. In the first section, the comprehensive concept of religion and its relationship with society, from Durkheim and Eliade, shall be reflected on. In the second section, the concept of State power based on the general theory of the State, by Hobbes and Rousseau, shall be taken up. In the third and final section, the relationship between religion and the Brazilian State based on its federal constitutions throughout its history shall be analyzed.

Keyword: Religion; State; Right; Secularism.

"Doutor e Mestre em Teologia, bacharel em Ciências Econômicas e em Teologia, licenciado em História. Docente do Programa de Pós-Graduação em Ciências das Religiões da Faculdade Unida de Vitória (PPGCR-UNIDA). E-mail: david@fuv.edu.br.

${ }^{* *}$ Mestranda em Ciências das Religiões no PPGCR da Faculdade Unida de Vitória, graduada em Fonoaudiologia e em Educação Física. E-mail: le.md@hotmail.com

${ }^{* * *}$ Mestranda em Ciências das Religiões no PPGCR da Faculdade Unida de Vitória, graduada em Direito. E-mail: luciaroriz@yahoo.com.br

${ }^{* * * *}$ Mestrando em Ciências das Religiões no PPGCR da Faculdade Unida de Vitória, graduado em Teologia e em Filosofia. E-mail: perobson@gmail.com 


\section{Introdução}

A religião é um fenômeno universal que se mostra na formação dos povos. A nação brasileira não seria uma exceção. Desde o Brasil colonial até a contemporaneidade, a religião desempenhou importante papel. Para evidenciar essa influência, o artigo está dividido em três momentos históricos no Brasil: colonial, imperial e republicano.

A primeira seção visa esclarecer a origem e a conceituação de religião a partir do pensamento de Durkheim (1996) e de Eliade (1992), que abordam a gênese da religião, bem como sua influência na sociedade. Durkheim a analisa como um fato social que atinge a coletividade, admitindo que a mesma é um todo integrado. Sob o olhar de Eliade, o indivíduo experimenta a realidade profana (secular), no entanto, busca incessantemente a presença do sacro, querendo permanecer no coração do sagrado.

A segunda seção apresenta o Estado e o poder estatal a partir da Teoria Geral do Estado. O fundamento teórico é a teoria da origem contratual do Estado, denominada de racionalista. Esta teoria justifica que o mesmo, tem início a partir de uma convenção (pactual, contratual), e, como produto da razão humana (pactista, contratualista).

Hobbes (2003) considera a inquietação dos indivíduos e a necessidade de se estabelecer um contrato social. Teriam abdicado de seus direitos em nome de um maior, fundando o Estado. Rousseau (1999) funda o contrato na igualdade dos seres humanos, denominada de vontade geral. Na parte relativa ao estado de natureza, a filosofia de Rousseau é oposta à de Hobbes. Para este autor, o estado de natureza primevo era um tempo de guerra mútua, enquanto, para Rousseau, era de felicidade perfeita, dado que o ser humano, em estado de natureza, é sadio, ágil e robusto. Todavia, nessa parte, a fundamentação teórica reside no entendimento de Hobbes que não é tão restrito. Com relação ao poder estatal, a teoria contratualista acentua que pactos sucessivos foram se firmando para dotá-lo de força e capacidade de proteção. Nessa perspectiva, o Estado é constituído pelos indivíduos, podendo recorrer à força e ao recurso de todos, convenientemente, para assegurar a paz e a defesa comum.

A terceira seção apresenta a análise da relação entre a religião e Estado, sob o enfoque do Brasil colonial e das posteriores Constituições Federais, desde o Brasil imperial à Constituição de 1988, com destaque aos vínculos, rupturas e 
dificul-dades existentes, abordando os distintos sistemas de relação entre essas grandezas, bem como os conceitos de laicidade e laicismo.

\section{Religião: origem e conceituação}

A religião é um fenômeno universal presente nas diversas culturas, existindo desde os primórdios. Dificilmente se encontrará um grupo social que não possua alguma forma de religiosidade a reger seus costumes, seu cotidiano e suas vidas (ASSIS \& KUMPEL, 2011, p. 69). A expressão religião remonta à palavra latina religio, significando, em seu primeiro sentido, um agrupamento de regras, observâncias, advertências e interdições, sem quaisquer referências a divindades, rituais, mitos ou quaisquer outras manifestações que, hodiernamente, entendemos como religiosas (SILVA, 2004, p. 2).

Segundo Sena (2016, p. 65), a expressão latina re-ligare tem referência no religar do ser humano com seus antepassados, mortos ou desencarnados, atitude codificada pela realização de rituais fúnebres e sepultamentos, constituindo a base embrionária da atitude religiosa, que sempre influenciou a relação dos indivíduos com o mundo, consigo mesmo, com os outros e com o que ele crê que está além deste mundo.

Ao analisar a religião, Durkheim (1996) a considera um fato social, já que engendra a essência da sociedade, sendo esta a alma da religião. Trata-se de "um sistema solidário de crenças e de práticas relativas a coisas sagradas, isto é, separadas, proibidas, crenças e práticas que reúnem numa mesma comunidade moral, chamada igreja, todos aqueles que a elas aderem" (DURKHEIM, 1996, p. 262). A essência da religião está contida no sagrado, como algo extraordinário. $O$ seu oposto, o profano, relaciona-se com as coisas ordinárias e mundanas. As distinções entre ambos, sagrado e profano, não coincidem com a distinção entre sobrenatural e natural. Coisas sobrenaturais não são necessariamente coisas sagradas, nem coisas sagradas são sobrenaturais. O sagrado está associado ao social. As crenças religiosas são representações coletivas e os principais rituais religiosos são praticados coletivamente (DURKHEIM, 1996, p. 32).

A investida da transformação da natureza da religião, segundo Eliade (1992), ocorre com o reconhecimento da manifestação do sagrado, isto é, das hierofanias. Para Eliade, as religiões se manifestam desde as hierofanias, somente existindo quando estas estão presentes. Elas são responsáveis pelo rompimento 
da homogeneidade do espaço profano. Quando ocorrem essas manifestações, uma realidade absoluta, um centro, um ponto fixo absoluto é revelado, e o ser humano religioso sempre investiu no sentido de se estabelecer no Centro do Mundo (ELIADE, 1992, p. 47).

Eliade alude que a hierofania é algo consagrador de um espaço, que se abre para o alto, realizando a comunicação com o céu. É a interface entre o céu e terra. A religião é resultado das hierofanias que produzem o rompimento de níveis, sendo que a existência humana carece da comunicação perene que ela estabelece com o céu. $O$ indivíduo tem a tendência de se mover unicamente num mundo santificado, fundado pelo sagrado. E é do próprio sagrado a responsabilidade de estabelecer a ordem naquele mundo, a ordem cósmica. Nesse raciocínio, o profano é ilimitado, não possuindo referências. Somente a experiência do sagrado estabelece os limites e as referências. E mais, somente ela é a própria referência (ELIADE, 1992, p. 48).

Segundo Coutinho (2012), na perspectiva eliadiana e durkheiminiana, o profano e o sagrado são realidades distintas. O ser humano, no seu início, via o sagrado como a divindade, posteriormente passou a distingui-los. Citando Borau, salienta que o sagrado é a ponte entre a divindade e o ser humano, convertendose de divindade em hierofania (COUTINHO, 2012, p. 176).

Nessa abordagem, a religião é a grande integradora da vida social. Logo, as diferenças e os conflitos entre os diferentes grupos sociais são deixados à margem em razão das afinidades existentes entre a fé, a religiosidade e os valores. Essa força integradora garante o reajustamento social e o equilíbrio de conflitos de classe, étnicos, dentre outros, favorecendo um sistema social integrado. Além disso, propicia auxílio às pessoas frente a situações econômicas debilitadas e tensões politicas (SCOTT, 2006, p. 47).

\section{Estado e poder estatal}

Nesta seção, evidencia-se o conceito de Estado, sua origem e seus elementos formadores, explicitando que a reunião de ideias e o senso comum deram origem à sociedade natural e esta, objetivando a eficácia do bem comum, através de regras e organização politica, formulou a ideia de Estado e o influxo da religião em sua formação. 
De acordo com Hobbes (2003), a doutrina teológico-religiosa de Tomás de Aquino e de Agostinho de Hipona pregava que tudo foi criado por Deus. A origem do Estado não seria proveniente do ser humano, nem do coletivo ou da ordem social, mas da Força maior que organizou o humano, transformando-o de homem-natural à homem-social (HOBBES, 2003, p. 143).

Thomas Hobbes, que viveu entre 1588 e 1679, foi integrante da teoria contratualista do Estado. Entendia que o ser humano vivera sem poder e sem organização, num período em que ele o denominou estado de natureza, o qual representava uma condição de guerra. Com intuito de evitar a guerra, Hobbes propôs que houve a necessidade de se criar o Estado para controlar e reprimir o indivíduo que vivia em estado de natureza. Logo, o Estado seria o único capaz de produzir a paz, e para tanto, o ser humano deveria ser supervisionado pelo Ente Estatal, legitimado por um contrato social (HOBBES, 2003, p. 143).

Nessa linha, o único caminho para erigir um poder comum, capaz de defender os seres humanos contra a invasão dos estrangeiros e contra as injúrias alheias, será conferir todo o poder e fortaleza a um indivíduo ou a uma assembleia de pessoas, que, por pluralidade de votos, possam reduzir suas vontades a uma vontade. Isto equivale dizer: eleger um indivíduo ou uma assembleia de pessoas que represente sua personalidade; e que cada um considere como próprio e se reconheça a si mesmo como autor de qualquer coisa que faça ou promova quem representa sua pessoa, naquelas coisas que concernem à paz e à segurança comum (HOBBES, 2003, p. 35).

John Locke refuta as ideias de Hobbes, aludindo ao estado de natureza um estado de perfeita liberdade, não sendo, todavia, um estado de licença. Era regido por uma lei natural que obrigava cada um, e, a razão, confundida com esta lei, ensinava o ser humano, sendo iguais e independentes, que nenhum deveria criar obstáculo a outro em sua vida, liberdade e em seus bens. Os indivíduos se uniram com intuito de formar uma sociedade, abdicando de uma parcela de sua liberdade natural, sem autorizar que as regras seriam impostas unilateralmente por um soberano, mas sim, por um pacto social (LOCKE, 2018).

Segundo Rousseau (1999), o Estado é convencional. Resulta da vontade geral, que é a soma da volição manifestada pela maioria dos indivíduos. A nação (povo organizado) é superior ao rei. Não há direito divino da Coroa, mas, sim, direito legal decorrente da soberania estatal. Esta é ilimitada, ilimitável, total e 
incontrastável. O Governo é instituído para promover o bem comum, e só é suportável enquanto justo. Caso não corresponda aos anseios populares que determinaram sua organização, o povo pode substituí-lo ante a autorização do direito, refazendo o contrato. Nessa vertente, o contrato social tem o objetivo de

encontrar uma forma de associação que defenda e proteja a pessoa e os bens de cada associação de qualquer força comum, e pela qual, cada um, unindo-se a todos, não obedeça, portanto, senão a si mesmo, ficando assim tão livre como dantes (ROUSSEAU, 1999, p. 35).

Maquiavel (2010), um dos precursores da ciência política e primeiro a ordenar os fundamentos do Direito Público moderno, introduz a expressão Estado na literatura científica em sua consagrada obra $O$ Príncipe, publicada em 1513. Seu objetivo, como cientista político, consistia em instaurar um Estado estável que pusesse fim ao eterno ciclo de instabilidade e caos reinante na dinâmica social de seu tempo (MAQUIAVEL, 2010, p. 11).

Para Darcy Azambuja (1997, p. 6), o Estado Moderno é uma sociedade à base territorial, dividida em governantes e governados, e que pretende, nos limites do território reconhecido, a supremacia, sobre as demais instituições. De fato, é o supremo e legal depositário da vontade social e fixa a situação de todas as organizações. Dalmo de Abreu Dallari (2007, p. 48) expõe este aspecto do Estado, quando preceitua que ele existe em função dos interesses de todos os indivíduos que o compõem, e para o atendimento desses interesses busca a consecução de fins gerais, visando atingir esses objetivos. Ele exerce um poder para alcançar eficácia, sobrepondo-se aos demais poderes e submetendo até aqueles que the dão existência.

Segundo Maluf (1998, p. 23), o Estado possui três elementos constitutivos, sendo que a falta de qualquer elemento descaracteriza a sua formação: povo, território e soberania.O povo é a reunião de individuos sujeitos às mesmas leis, os súditos, os cidadãos de um mesmo Estado, considerando-se o aspecto puramente jurídico (AZAMBUJA,1997, p. 19). Mario Lúcio Quintão Soares (2008, p. 152), citando Kriele, menciona uma distinção entre povo e nação, sendo esta, o povo que adquiriu consciência ou a consciência de pertencer à mesma comunidade.

O segundo elemento do Estado é o território, a base física, onde a soberania é exercida na sua plenitude. Esse âmbito geográfico da nação é onde ocorre a validade da sua ordem jurídica. A nação, como realidade sociológica, pode sub- 
sistir sem território próprio, sem se constituir em Estado. Todavia, Estado sem território não é Estado (DANTAS, 2008, p. 91).

O último elemento, a soberania, é a qualidade essencial do Estado, o direito ou poder de emitir comandos obrigatórios (KELSEN, 2000, p. 301). Águila (2005, p. 23), ao tratar de soberania e poder do Estado, afirma ser produto de uma relação, em que alguns obedecem e outros mandam, estando relacionado a valores que propiciam autoridade e legitimidade para mandar, e o assentimento para ser obedecida. Para Águila (2005, p. 26), rotineiramente, o poder caracteriza a autoridade, sendo esta a expressão do poder legitimado no momento em que as relações sociais entre governantes e governados se estabilizam. A obediência é uma consequência sem necessidade de se recorrer à força ou, à violência.

Dallari (2006, p. 33), com base nos estudos da teoria de Burdeau, afirma que o poder é um elemento essencial ou uma nota característica do Estado e contém certas peculiaridades que o qualificam. A mais importante é a soberania. Para Reale (2000, p. 112), não pode existir Direito Positivo sem o poder. O Direito estatal, para ter o grau de plena positividade jurídica, depende da existência do poder. Ele propicia a organização da coação através da aplicação das normas jurídicas. Direito positivo e poder, por conseguinte, são termos inseparáveis, sendo que vão procurar reduzir o primeiro ao segundo, ou, contrapor um ao outro.

\section{A relação entre Estado brasileiro e religião}

Esta seção apresenta a interconexão entre Estado e religião, como resultado da história brasileira desde o século XVI. Demonstra o poder construído, no período colonial, quando o catolicismo foi declarado religião oficial, e funcionava como instrumento de dominação social, política e cultural. Em seguida, trata as relações de poder entre Estado e religião após a proclamação da independência em 1822 e demais Constituições brasileiras até 1988.

\section{Aspectos do Brasil colonial}

Igreja e Estado se confundiam enquanto instituições legitimadoras do poder e normatizadoras dos corpos e das mentes. Ambas as instituições tinham como pretensão a regulação dos princípios organizadores da sociedade, a conquista da consciência dos sujeitos e a detenção do monopólio do capital simbóli- 
co no imaginário social. À época, a nação brasileira foi regida pela legislação portuguesa, ou seja, pelas Ordenações (Manuelinas, Afonsinas e Filipinas), quando o direito esta-tal se confundia com o direito divino, isto é, o direito ditado pela Igreja Católica (EMMERICK, 2010, p. 145).

Segundo Martins e Câmara (2012), a religião sempre esteve presente, consequentemente, refletida, em maior ou menor grau, nas leis do país. O Brasil, desde a sua colonização contou com a forte presença da Igreja Católica, que foi a religião oficial durante parte de sua história. Esta presença é perceptivel na cultura, nos costumes e nos valores deste corpo social.

O padroado sacramentava a união entre Igreja e Estado. A proporção que o rei se tornava medida na politica e na religião, a Coroa Portuguesa incorporava os símbolos tanto da Igreja quanto do Estado. A consequência dessa união foi uma íntima colaboração do poder estatal e eclesiástico (SORIANO, 2002, p. 37). No plano teórico, Peter Berger (1985, p. 42) explica que as instituições políticas e governamentais garantem sua legitimidade pelo fato da religião transformar o poder civil em poder sacramental.

Quanto à evangelização dos indivíduos em terras brasileiras, a Igreja Católica deteve o monopólio no controle da vida dos cidadãos, principalmente em matéria de educação e família. Assim, ditava o que era ou não moral e juridicamente aceitável, já que as leis vigentes no Brasil Colônia eram as mesmas de Portugal e, não raramente, confundiam-se com as leis de Deus, ou melhor, com as leis ditadas pela Igreja. Evidente, assim, que a atuação católica foi muito além do campo religioso, estendendo-se ao espaço social e político (EMMERICK, 2010, p. 145). A Igreja era também a única forma de serviço social que se conhecia, dando amparo aos velhos, órfãos e enfermos, cuidando da educação das crianças e organizando a maioria das festas populares (MOLINA, 2015, p. 37).

As relações entre Igreja Católica e Estado foram estreitas tanto no Brasil Colônia quanto no Império, pois, além de garantir a disciplina social, a Igreja também executava tarefas administrativas que hoje são atribuições do Estado, como o registro de nascimentos, de mortes e de casamentos. Em contrapartida, o Estado nomeava bispos e párocos, além de conceder licenças para construção de novas igrejas (CASTRO, 1998).

\section{Aspectos do Brasil imperial}


A Constituição editada em 1824 conferiu à Igreja Católica o título de religião oficial do Império, permitindo os mesmos controles e concedendo as prerrogativas da época colonial, demonstrando que a separação, nesse período, ainda era precária ou inexistente. A independência não modificou a tutela estatal sobre a Igreja e as mútuas influências. Ela continuou a atuar além do campo religioso, exercendo forte incidência no campo social e político (SILVA, 2010, p. 23).

A Constituição imperial de 1824 dispôs expressa autorização ao culto doméstico das demais religiões, realizado, sem propagação pública, somente no interior das residências dos seus fiéis ou em outros espaços físicos, proibidos os cultos públicos e as formas exteriores que denotassem templos (PONZILACQUA, 2016, p. 15).

Logo após a independência, os direitos civis reconhecidos sofreram restrições "em decorrência de uma herança colonial pautada na escravidão e no domínio do poder econômico da elite agroexportadora, o que contribuía para a negação dos direitos básicos à grande parte da população" (SILVA, 2010, p. 23).

A Constituição imperial trouxe no seu bojo uma série de dispositivos, regulando a legitimação da Igreja Católica, iniciando-se pelo preâmbulo, que inaugurava a ordem constitucional invocando a Santíssima Trindade. Isto indica que o poder imperial recorreu ao poder religioso católico para legitimação do poder e para coesão social (EMMERICK, 2010, p. 149).

Conforme Aguiar, Lima \& Santos (2013), durante o Brasil Império, o Estado e a Igreja mantiveram íntima e oficial ligação. Com o advento da República, esse laço se rompera, tornando o Estado, oficialmente, laico. Todavia, a Igreja manteve todos os privilégios decorrentes das relações anteriores. Em sua ótica, toda a trajetória brasileira, inclusive na atualidade, percebe-se a influência da religião desde a gênese, concepção e aplicação das normas sociais e jurídicas.

\section{Aspectos do Brasil republicano}

Na visão de Lísias Nogueira Negrão (2008, p. 263), a proclamação da República não significou a perda da hegemonia católica e de sua influência na vida cultural e politica brasileira. A Igreja continuou a cooperar eventualmente com o Estado republicano, como no combate às heresias messiânicas e a impor seus princípios religiosos às Constituições. A herança do catolicismo colonial e imperial foi, de certa forma, preservada, apesar das transformações republicanas. 
No período anterior à proclamação da República, por volta de 1890, houve um processo de crítica em desfavor da Igreja Católica, contribuindo para seu enfraquecimento e desprestígio. Os ideais revolucionários da época fomentavam o rompimento das algemas que ligavam o Estado à Igreja. Estes novos princípios eram observados no cenário político e no cenário religioso, sendo este último, amplamente combatido pelo ateísmo e pelo positivismo, com o devido apoio dos governantes (SCAMPINI, 1978, p. 82). Apaziguados os ânimos, os novos governantes cuidaram de efetivar a separação. Os primeiros rascunhos saíram das mãos do ministro da agricultura, Demétrio Ribeiro. Em razão das diversas retaliações sofridas, o General Deodoro da Fonseca pediu ao Ministro da Fazenda a criação de outro (SCAMPINI, 1978, p. 83). Após esse intenso debate, foi editado o Decreto n. 119A, de 7 de janeiro de 1890, rompendo os últimos laços da Igreja com o Estado, dando ao país o caráter laico, leigo ou não confessional (SCAMPINI, 1978, p. 84).

Com o início do regime republicano, houve efetiva separação entre Estado e Igreja. Todavia, o poder constituinte de 1891 ainda tinha arraigado algumas convicções religiosas, estando a Igreja, ainda que veladamente, exercendo influência corporativa sobre os parlamentares (SCAMPINI, 1978, p. 152).

A laicidade do Estado provocou no plano fático, lentas e gradativas modificações, vigendo até 1934, quando o presidente Getúlio Vargas convocou nova Assembleia Nacional Constituinte (REIMER, 2013, p. 57). A Constituição de 1934 manteve o Estado laico e mostrou maior abertura à colaboração das igrejas, embora condicionasse a liberdade de crença à ordem pública e aos bons costumes - o que poderia abrir brechas de interpretação da autoridade estatal em tais questões. Restringiu, indevidamente, a atuação de algumas denominações religiosas que fossem contrárias à ideologia da religião predominante, indicando a prevalência dos interesses católicos junto aos poderes constituídos do Estado (SCAMPINI, 1978, p. 150).

No capítulo referente aos direitos e garantias individuais, a Constituição de 1934 concede liberdade de religião:

Art. 113 - A Constituição assegura a brasileiros e a estrangeiros residentes no País a inviolabilidade dos direitos concernentes à liberdade, à subsistência, à segurança individual e à propriedade, nos termos seguintes: 1) Todos são iguais perante a lei. Não haverá privilégios, nem distinções, por motivo de nascimento, sexo, ra- 
ça, profissões próprias ou dos pais, classe social, riqueza, crenças religiosas ou ideias politicas (BRASIL,, 1934, [n.p.]).

Com a instauração do Estado Novo por Getúlio Vargas, foi decretada e outorgada a Constituição de 1937, que integrava elementos do autoritarismo vigente na Europa à época. Com relação à liberdade religiosa e ao Estado laico, não houve inovação em relação à anterior Constituição (OLIVEIRA, 2010, p. 69).

A Constituição de 1946, fruto da redemocratização do país, promulgada por uma Assembleia Constituinte, apresentou avanços na relação entre Estado e religião. O Estado laico foi reafirmado, a liberdade religiosa mantida, embora tenha condicionado a religião à ordem pública e aos bons costumes. A colaboração entre Igreja e Estado foi ampliada, com vedação dos entes federados a lançarem impostos sobre templos de qualquer culto (SCAMPINI, 1978, p. 152).

A Constituição de 1946 trouxe algumas inovações: tratou de restaurar o princípio constitucional liberal moderno da separação e interdependência dos três poderes (Art. 7, inciso VII, alinea b); assinalou o retorno dos direitos fundamentais e das garantias que haviam sido suprimidos na Constituição de 1937; restaurou a liberdade na manifestação de pensamento sem censura; a inviolabilidade do sigilo de correspondência (Art. 141, parágrafo $6^{\circ}$ ) estava garantida, assim como a inviolabilidade da casa como asilo do indivíduo (Art. 141, Parágrafo 15) (Reimer, 2013, p. 64).

A Constituição de 1967, ao tratar dos direitos e garantias individuais, assegurou a liberdade religiosa aos brasileiros:

Art. 150 - A Constituição assegura aos brasileiros e aos estrangeiros residentes no País a inviolabilidade dos direitos concernentes à vida, à liberdade, à segurança e à propriedade, nos termos seguintes: $\S 1^{\circ}$ - Todos são iguais perante a lei, sem distinção, de sexo, raça, trabalho, credo religioso e convicções políticas (BRASIL, 1937, [n.p.]).

Durante a vigência da Constituição de 1967, a mesma sofreu a Emenda Constitucional n. 1, de 17 de outubro de 1969. Esta nova Constituição também trouxe diversos dispositivos acerca da liberdade religiosa. O primeiro a ser mencionado trata da separação entre Estado e Igreja, conforme artigo $9^{\circ}$, que estabelecia que à União, aos Estados, ao Distrito Federal e aos Municípios é vedado estabelecer cultos religiosos ou igrejas, subvencioná-los, embaraçar-lhes o exercício ou manter com eles, ou seus representantes, relações de dependência ou aliança, ressalvada a colaboração de interesse público, na forma e nos limites da 
lei federal, notadamente no setor educacional, no assistencial e no hospitalar (REIMER, 2013, p. 69).

A história brasileira apresenta fatos e incidentes notórios que demonstram que não houve liberdade de consciência durante o período militar, mesmo com a garantia constitucional, a exemplo da censura aos meios de comunicação. Semelhante ocorreu no âmbito da liberdade de religião, pois, caso alguma religião ou líder esboçasse no culto, ou na crença, algum ideal de justiça social, apareceria como suspeito de inclinação comunista, estando sujeito a detenções arbitrárias e fora da legalidade (OLIVEIRA, 2010, p. 28).

Segundo Reimer (2013, p. 73), a década de 1980 marcou a inicialização do processo de redemocratização do país, concretizando-se com a promulgação da Constituição de 1988, tendo esta Carta Magna reconhecido muitos direitos, dentre eles, a liberdade religiosa em suas mais variadas nuances. Quanto à liberdade de consciência, de crença e de culto, foram considerados direitos invioláveis. Todavia, a inviolabilidade prescrita, não tem caráter absoluto. Não existem direitos absolutos, pois, todos encontram limites nos demais direitos, também consagrados na Carta Magna. A liberdade à consciência é mais ampla que a de crença, pois, envolve questões religiosas, politicas e filosóficas. Já a liberdade de crença está relacionada apenas com aspectos religiosos.

O artigo $5^{\circ}$, no inciso VIII da Constituição Federal de 1988, assegura que:

ninguém será privado de direitos por motivo de crença religiosa ou de convicção filosófica ou política, salvo se as invocar para eximirse de obrigação legal a todos imposta e recusar-se a cumprir prestação alternativa, fixada em lei (BRASIL, 1988, [n.p.]).

Conforme Soriano (2002, p. 10), o direito à liberdade religiosa é múltiplo, e compreende diversos direitos. Deve ser considerado um direito composto, tendo, ainda, possibilidade de decomposição em quatro vertentes: 1) liberdade de consciência: de foro individual e mais ampla que a liberdade de crença; 2) liberdade de crença: conhecida como liberdade de religião ou liberdade religiosa; 3) liberdade de culto: resulta da exterioridade da crença; e 4) liberdade de organização religiosa: decorre do Estado laico.

Na visão de Silva (2007, p. 250), as relações entre religião e Estado sofrem classificações conforme o grau de intensidade. Ao analisar essa relação, indicou três sistemas sujeitos a gradações: a confusão, a união e a separação. Para Rive- 
ro \& Moutouh (2006, p. 526), o sistema de separação, decorre do conceito de Estado Laico, que "é, pois, aquele que se situa fora de toda obediência religiosa e deixa no setor privado as atividades confessionais". O Estado hesitou em privar sua autoridade de um alicerce sobrenatural e em deixar autonomia às igrejas. No sistema laico, a independência recíproca das duas áreas é completa, sendo que um não penetra no outro. Mas, são possíveis diversas modalidades de laicidade, já que a separação pode deixar espaço para relações, com maior ou menor cordialidade, ou, ainda, assumindo a forma de uma ignorância total do fato religioso pelo Estado.

Para Santos Júnior (2007, p. 63), a laicidade determinada pela Constituição Federal de 1988 é a base ideológica do regime da liberdade de religião e do direito fundamental daí decorrente, estando disposta no inciso I, do artigo 19, da Carta Constitucional. Na sua visão, há dois modelos básicos de laicismo estatal. O primeiro modelo de Estado laico é aquele que pugna por uma separação tendente a restringir a religião ao foro íntimo das pessoas, isolando-a do espaço público. O segundo modelo é aquele que, enxergando no fenômeno religioso um importante elemento de integração social, permite expressões de religiosidade nos espaços públicos, chancelando-as de diversos modos. Logo, o laicismo expressa o sistema jurídico-político no qual, Estado e organizações religiosas não sofrem interferências reciprocas ao atendimento de suas finalidades institucionais.

A laicidade, por seu turno, seria simplesmente a qualidade de laico, o caráter de neutralidade religiosa do Estado. Entre um modelo e outro, há diversas gradações, considerando as peculiaridades de cada ordenamento jurídico nacional e a tradição de cada povo, havendo, também, circunstâncias históricas específicas que explicam o porquê da prevalência em um dado sistema jurídico de uma concepção mais próxima deste ou daquele modelo. O Brasil mantém os princípios da separação e da colaboração.

Giumbelli (2002, p. 454), afirma que a laicidade é uma categoria que tende a remeter para modelos. Esses modelos não devem ser confundidos com as descrições da realidade, ou seja, não devem ser sinônimo do funcionamento efetivo das sociedades seculares. A redefinição das fronteiras entre o religioso e o político é um desafio à ideia de secularização na contemporaneidade. Tal fato indica que nenhum modelo ideal dará conta das complexas interações entre religião e Estado. 
Segundo Habermas (2007), no Estado regido por uma Constituição democrática, onde o poder político não mais se fundamenta no transcendental, faz-se necessário preencher a lacuna em termos cosmológicos do referido poder:

As expectativas e os modos de pensar e de se comportar dos cidadãos, que não podem ser simplesmente impostos mediante o direito, podem ser, no entanto, explicitados a partir desses dois componentes da legitimação. As condições para uma participação bem-sucedida na prática comum de autodeterminação definem o papel de cidadão do Estado: os cidadãos devem respeitar-se reciprocamente como membros de sua respectiva comunidade politica, dotados de iguais direitos, apesar de seu dissenso em questões envolvendo convicções religiosas e visões de mundo (HABERMAS, 2007, p. 157).

A liberdade de religião é inerente à condição humana, e a religiosidade é um fenômeno sociológico que ganha importância jurídica, graças aos princípios constitucionais de liberdade. Todavia, a secularização em países de tradição católica não se dá na mesma velocidade que em países de tradição calvinista, por exemplo. Conquanto constitua um fenômeno que alcança todo o mundo ocidental, apresenta-se diferente nos diversos Estados, por razões diversas, dentre as quais se inclui até mesmo a concepção teológica sustentada pela religião majoritária (OLIVEIRA, 2011).

\section{Conclusão}

Pode-se observar na história do Brasil, que o vínculo entre religião e Estado não se rompeu. Percebem-se algumas rupturas entre uma Constituição e outra, gerando dificuldades para se estabelecer os limites de atuação entre religião e Estado, em que pese a adoção do sistema de separação entre Estado e Igreja. Uma coisa é a letra da lei, outra, a forma como os agentes se articulam e influenciam a vida social. No caso brasileiro, a força da religião majoritária, o catolicismo, com tantos privilégios e prerrogativas ao longo de séculos, sedimentou-se na sociedade, especialmente no período colonial, na forma de cultura e de visão de mundo, modelando a ação social. Essa influência cultural e religiosa criou o que se pode chamar de tradição, sendo reproduzida nas Constituições brasileiras.

O período colonial foi marcado pela união da Igreja Católica com o Estado, onde a primeira atuou em assuntos diversos além da esfera eclesiástica, enquanto agia sob o patrocínio do Estado. A Constituição imperial de 1824 manteve 
o catolicismo como religião oficial, limitando as demais confissões e religiões. As relações entre Estado e Igreja, apesar de as disposições constitucionais separatistas da Constituição de 1891 serem destoantes do plano dos fatos, muito contribuiu para a garantia da liberdade e da igualdade dos cidadãos. A Constituição republicana de 1891 foi um marco para a laicidade do Estado brasileiro. As Constituições subsequentes, sob a égide do regime jurídico constitucional separatista entre religião e Estado, não foi suficiente, nem no plano jurídico, nem no plano social, para configurar uma ampla distanciação legal.

A Constituição de 1988 consagrou a liberdade religiosa no Brasil como um direito fundamental e como resposta ao tempo histórico de reabertura, após um período de regime ditatorial militar, que exigiu um novo pacto constitucional. Ao mesmo tempo, a Carta Magna vigente delimitou a relação entre Estado e as organizações religiosas, através da noção de Estado laico e das respectivas vedações que a laicidade impõe. As organizações religiosas têm o direito de autoorganização e autodeterminação, cabendo ao Estado protegê-las, sem distinguir entre elas, sem beneficiar uma delas.

O modelo teórico da separação entre religião e Estado, possivelmente não é o ponto de partida mais apropriado para analisar a realidade brasileira. O regime de separação entre ambas as instituições sociais, assinalado pelas Constituições nacionais, não se dá uniformemente, mas com movimentos assimétricos, avanços e retrocessos, com maior ou menor proximidade entre um e outro. Ademais, determinar a exata relação entre a religião e o poder estatal, ante o entremeio do sagrado e a compreensão da religião como um fato social, com influxo na maneira de agir dos indivíduos ou de uma coletividade, não é tarefa fácil. As fronteiras não são claras e a influência da religião permanece, apesar do regramento jurídico, indicando que o campo de atuação da religião é profundo, enraizando-se como cultura e como cosmovisão.

\section{Referências bibliográficas}

AGUIAR, Itamar Pereira de; LIMA, Bruna Havena Aragão; SANTOS, Guilherme Ribeiro Miranda dos. Religião e sociedade: as relações entre o estado e as concepções religiosas na formação do ordenamento social e jurídico. Cadernos de Ciências Sociais Aplicadas. Vitória da Conquista, ano XIII, n. 12, 2013. p. 9-31.

ÁGUILA, Rafael del. Manual de ciencia politica. Madrid: Trotta, 2005. 
ASSIS, Olney Queiroz; KUMPEL, Vitor Frederico. Manual de antropologia juridica. São Paulo: Saraiva, 2011.

AZAMBUJA, Darcy. Teoria geral do Estado. 36 ed. São Paulo: Globo, 1997.

BERGER, Peter. O dossel sagrado: elementos para uma teoria sociológica da religião.São Paulo: Paulinas, 1985.

BRASIL. Constituição (1934). Constituição da República Federativa do Brasil. Brasília: Senado Federal. Disponivel em http://www.planalto.gov.br/ccivil_03/constituicao/constituicao34.htm. Acesso em 25 de fevereiro de 2021.

BRASIL. Constituição (1937). Constituição da República Federativa do Brasil. Brasília: Senado Federal. Disponivel em http://www.planalto.gov.br/ccivil_03/Constituicao/Constituicao37.htm. Acesso em25 de fevereiro de 2021.

BRASIL. Constituição(1988). Constituição da República Federativa do Brasil. Brasília: Senado Federal. Disponivel em https://www2.senado.leg.br/bdsf/bitstream/handle/id/518231/CF88_Livro_EC 91_2016.pdf>. Acesso em25 de fevereiro de 2021.

CASTRO, José Luiz. A organização da Igreja Católica na Capitania de Goiás (1726-1824). Dissertação (Mestrado em História). Goiânia: UFG, 1998.

COUTINHO, José Pereira. Religião e outros conceitos. Sociologia, v. XXIV. Porto, 2012, p. 171-193. $\quad$ Disponivel em https://ler.letras.up.pt/uploads/ficheiros/10763.pdf. Acesso em 25 de fevereiro de 2021.

DALLARI, Dalmo de Abreu. Elementos de teoria geral do Estado. São Paulo: Saraiva, 2006.

DALLARI, Dalmo de Abreu. O futuro do Estado. $2^{\circ}$ ed. São Paulo: Saraiva, 2007.

DANTAS, Ivo. Teoria do Estado contemporâneo. Rio de Janeiro: Forense, 2008.

DURKHEIM, Émile. As formas elementares da vida religiosa. São Paulo: Martins Fontes, 1996.

ELIADE, Mircea. O sagrado e o profano. São Paulo: Martins Fontes, 1992.

EMMERICK, Rullian. As relações Igreja/Estado no direito constitucional brasileiro: um esboço para pensar o lugar das religiões no espaço público na contemporaneidade. Revista Latino-Americana.Rio de Janeiro,n. 5, 2010. p. 144-172.

GIUMBELLI, Emerson. O fim da religião: dilemas da liberdade religiosa no Brasil e na França. São Paulo: Attar, 2002.

HABERMAS, Jürgen. Entre naturalismo e religião: estudos filosóficos. Rio de Janeiro: Tempo Brasileiro, 2007.

HOBBES, Thomas. Leviatã ou matéria, forma e poder de um Estado eclesiástico e civil. São Paulo: Martin Claret, 2003.

KELSEN, Hans. Teoria geral do direito e do Estado. $3^{\circ}$ ed. São Paulo: Martins Fontes, 2000. 
LOCKE, John. Segundo tratado do governo civil. Petrópolis: Vozes, 2018.

MAQUIAVEL, Nicolau. O príncipe. São Paulo: Penguin, 2010.

MALUF, Sahid. Teoria geral do Estado. São Paulo: Saraiva, 1998.

MARTINS, Edson; CÂMARA, Uipirangi Franklin da Silva. Direito e religião no Brasil. Anima.Curitiba, ano X, n. 17, 2017. Disponivel emhttp://animaopet.com.br/pdf/anima17/INTERNO/2-interno-Direito-e-religiao-no-Brasil-

Martins-Cama-ra.pdf. Acesso em25 de fevereiro de 2021.

MOLINA, Matias M.História dos jornais no Brasil. São Paulo: Schwarcz, 2015.

NEGRÃO, Lísias Nogueira. Pluralismo e multiplicidades religiosas no Brasil contemporâneo. Sociedade e Estado. Brasília, v. 23, n. 2, 2008. p. 261-279.

OLIVEIRA, Patrícia Elias Cozzolino. A proteção constitucional e internacional do direito à liberdade de religião. São Paulo: Verbatim, 2010.

OLIVEIRA, Fábio Dantas. Aspectos da liberdade religiosa no ordenamento jurídico brasileiro. 2011. Disponivel emhttps://jus.com.br/artigos/19770/aspectos-daliberdade-religiosa-no-ordenamento-juridico-brasileiro. Acesso em25 de fevereiro de 2021.

PONZILACQUA, Marcio Henrique Pereira. Direito e religião: abordagens específicas. Ribeirão Preto: SDDS/FDRP USP, 2016.

REALE, Miguel. Globalização e Estado nacional, filosofia e teoria politica: ensaios. São Paulo: Saraiva, 2000.

REIMER, Haroldo. Liberdade religiosa na história e nas Constituição do Brasil. São Leopoldo: Oikos, 2013.

RIVERO, Jean; MOUTOUH, Hugues. Liberdades públicas. São Paulo: Martins Fontes, 2006.

ROUSSEAU, Jean-Jacques. O contrato social. $3^{\circ}$ ed. São Paulo: Martins Fontes, 1999.

SANTOS JUNIOR, Aloísio Cristovam dos. A liberdade de organização religiosa e o Estado laico brasileiro. São Paulo: Mackenzie, 2007.

SCAMPINI, José. A Liberdade religiosa nas Constituições brasileiras: estudo filosófico-jurídico comparado. Petrópolis: Vozes, 1978.

SCOTT, John. Sociologia: conceitos-chave. Rio de Janeiro: Zahar, 2006.

SENA, José Roberto. A religião nas concepções dos clássicos Marx e Durkheim: felicidade ilusória ou transfiguração da sociedade?Diversidade Religiosa. João Pessoa: v. 6, n. 1, 2016. p. 64-86.

SILVA, Eliane Moura. Religião, diversidade e valores culturais: conceitos teóricos e a educação para a cidadania. Rever. São Paulo: PUC-SP, n. 2, ano IV, 2004. p. $1-14$.

SILVA, José Afonso. Curso de direito constitucional positivo. $28^{\circ}$ ed. São Paulo: Malheiros, 2007. 
SILVA, Alda Fernanda Sodré Bayma. A constitucionalização da liberdade religiosa enquanto direito fundamental: uma análise da tutela e efetividade do direito à liberdade religiosa à luz da Constituição Federal de 1988 e jurisprudências. Monografia (Graduação em Direito). São Luís: UFMA, 2010.

SOARES, Mario Lúcio Quintão. Teoria do Estado: novos paradigmas em face da globalização. $3^{\circ}$ ed. São Paulo: Atlas, 2008.

SORIANO, Aldir Guedes. Liberdade religiosa no direito constitucional e internacional. São Paulo: Juarez de Oliveira, 2002.

Recebido em 26/02/2021

Aceito para publicação em 26/03/2021 


\title{
Jesus histórico e a América-Latina:desenvolvimento e contribuições em meio à Teologia Latino-Americana
}

\author{
Historical Jesus and Latin America: development and contributions in the midst \\ of Latin American theology
}

\author{
Mateus Soares Guedes* \\ Flávio Schmitt* \\ doi) $\underline{\text { https://doi.org/10.29327/256659.12.2-16 }}$
}

Resumo:

O presente artigo investiga como a Teologia Latino-americana vê o Jesus histórico e constrói sua teologia a partir dele, além de observar as implicações para a sociedade. Para tanto, faz-se necessário entender o que é esse Jesus Histórico. Entende-se o Jesus Histórico como um resultado da pesquisa científica a partir de interdisciplinaridade, que é característica da terceira fase da pesquisa sobre Jesus, a third quest. Assim, observa-se que a Teologia Latino-Americana, acolhe os resultados dessa pesquisa sobre Jesus e a partir disso constrói sua teologia, tendo uma tarefa importante, discutir fé e história. Dessa forma, os teólogos latino-americanos entenderam que o Jesus Histórico é a base da fé, de tal modo que o ponto de partida para uma cristologia latino-americana deve ser o Jesus histórico. Assim, a partir da observação histórica de Jesus, compreende-se Jesus em meio a um contexto de opressão e injustiças, o qual aplica a sua mensagem para esses contextos. Considerando que a mensagem e vida de Jesus está permeada por diversos aspectos sociais, econômicos, políticos e ideológicos, a teologia apresentada na América Latina também deveria estar envolvida em uma luta contra a opressão e injustiça social, já que o contexto político-social da América Latina está permeado por diversos tipos de opressão, exploração e injustiças.

Palavras-chave: Jesus histórico. Teologia Latino-americana. Sociedade.

\section{Abstract:}

This article investigates how Latin American theology sees the historical Jesus and builds his theology from it, as well as observing the implications for society. To do this, it is necessary to understand what this Historical Jesus is. The Historical Jesus is understood as the result of scientific interdisciplinary research, which is characteristic of the third phase of the research on Jesus, the third quest. Thus, it is noted that Latin American theology welcomes the results of this research on Jesus and from this builds his theology, having an important task, discussing faith and history. In this way, Latin American

\footnotetext{
*Graduado em Teologia pela Faculdade Teologia Batista Equatorial; Mestrando em Tradições e Escrituras Sagradas pela Escola Superior de Teologia (EST), como bolsista CNPq. Email: mateussguedes@outlook.com.

** Doutor em Ciências da Religião pela UMESP, professor na Faculdades EST em São Leopoldo/RS. E-mail: flavio@est.edu.br.
} 
theologians will understand that the Historical Jesus is the basis of faith, so the starting point for a Latin American Christology must be the historical Jesus. Thus, since the historical observation of Jesus, Jesus is understood during a context of oppression and injustice, which applies his message to these contexts. Considering that the message and life of Jesus is imbued with various social, economic, political, and ideological aspects, the theology presented in Latin America must also be involved in a fight against oppression and social injustice, since the political and social context of Latin America is imbued with various types of oppression, exploitation, and injustice.

Keywords: Historical Jesus; Latin American theology; Society.

\section{Introdução}

Falar de Jesus histórico é uma tarefa perigosa, porém necessária. Por um lado, há o perigo da cansativa repetição, já que se trata de um tema que é pesquisado desde o século XVII. Dessa forma, trabalhar um tema que perpassa ao menos cinco séculos, de muita pesquisa e discussão, é um desafio muito grande para que não se caia na repetição enfadonha do tema, ou para que não se enquadre na afirmação de D. Crossan: "a pesquisa do Jesus histórico está virando uma piada acadêmica sem graça”(CROSSAN, 1994, p. 26). Por outro lado, há uma necessidade muito grande dessa pesquisa, pois é a partir dela que existe a possibilidade de uma construção mais próxima de quem de fato foi Jesus de Nazaré, e de uma teologia próxima a pessoa histórica de Jesus e seu movimento.

Algumas perguntas, contudo, são suscitadas desde agora, e que perpassarão pelo presente artigo. Entre elas, é necessário indagar se após vários anos de pesquisa no tema, ainda há necessidade da pesquisa do Jesus histórico, além de nos perguntarmos a necessidade desse Jesus histórico para a teologia latinoamericana. Clifford Geertz, afirma: "à medida que o homem muda, muda também o mundo do senso comum, pois ele é visto agora como uma forma parcial de uma realidade mais ampla que o corrige e o completa" (GEERTZ, 2008, p. 89). De tal modo, é inegável que os tempos, desenvolvimentos e condições sociais moldam as pessoas e suas visões de mundo, e consequentemente o pesquisador e a pesquisadora, afetando assim a própria pesquisa.

Esse fato é visto ainda mais na própria acusação de Albert Schweitzer (2003) aos teólogos liberais que o antecederam e que tiveram um papel importante, em sua época, na pesquisa do Jesus histórico. Para ele, a pesquisa desses teólogos refere-se muito mais aos frutos de suas obstinações do que um propósito maior de encontrar o verdadeiro Jesus histórico. Ou, em outras palavras, o caráter projetivo das imagens da vida de Jesus estava de acordo com os seus autores (THEISSEN; MERZ, 2002, p. 24).Dessa maneira, levando em consideração a 
constante mudança e evolução da humanidade, inclusive na pesquisa científica (métodos, materiais e descobertas), pode-se afirmar que sempre haverá uma necessidade de uma revisão ou uma nova busca pelo Jesus histórico.

Em outras palavras, apesar de anos de pesquisa sobre o tema, ele se faz inesgotável. Pedro Ramão Hilgert (1987), por exemplo, entende que o Jesus histórico é "renovado" de tempos em tempos exatamente porque os tempos demandam a compreensão de sua pessoa e missão, e por isso essa busca não cessa. Ou seja, a pesquisa do Jesus histórico, apesar da produção escrita tratando sobre o tema, se faz necessária a partir de uma "nova realidade" vivida nos tempos atuais.

Com base nas afirmações postuladas anteriormente, é importante pensar sobre um Jesus histórico no âmbito latino-americano, além de relacioná-lo não somente com a teologia, mas também com a sociedade. Se a visão de mundo, o ambiente e a posição social de uma determinada maneira moldam a pesquisa, é importante entender as relações da teologia latino-americana com a pesquisa do Jesus histórico, além disso, observar as implicações dessa relação para a sociedade.

Esse artigo, portanto, pretende discutir as relações que a teologia latinoamericana possui com essa pesquisa sobre o Jesus Histórico e as implicações para a sociedade na América Latina. Para tanto, três passos serão desenvolvidos: 1) Tentar-se-á definir o que é a pesquisa do Jesus histórico e onde a mesma ocorre; 2) Apresentar como a TLA, ${ }^{1}$ pensa Jesus histórico e como ela o desenvolve; 3) Discutir as contribuições desse foco tanto para a pesquisa como para a sociedade.

Para tanto, alguns autores se fazem importantes na pesquisa tanto do Jesus histórico como na discussão da Teologia Latino-Americana. Sobre o Jesus histórico, a pesquisa passa pelos nomes de Albert Schweitzer, Dominic Crossan, Wolfgang Stegemann, Gerd Theissen e John Meier. Já em relação aos desenvolvimentos na América Latina tanto em termos de teologia como de sociedade a presente pesquisa tem por base Maria Clara Bingemer, Rubem Alves, Gustavo Gutierrez, Jon Sobrino, Jessé Souza e Eduardo Galeano.

Dessa forma, portanto, não se pretende somente explanar os diversos comentários, ou teologias, sobre Jesus, feitos por teólogos latino-americanos baseados no Jesus histórico. Mas, o objetivo é procurar refletir sobre o desenvolvimento e as contribuições da TLA a partir do Jesus histórico. 


\section{Jesus Histórico: lugar e definição}

O termo Jesus histórico é um termo bastante abrangente, especialmente quando se trata sobre a sua pesquisa. Para dar um exemplo do panorama da discussão, é possivel mencionar que o próprio nome "Jesus histórico" é questionado para referir-se a essa pesquisa. Outras possibilidades como o "Jesus real" utilizado por Gerd Lüdemann e Klaus Berger ${ }^{2}$, e em uma discussão mais recente, o Jesus lembrado, expressão trazida especialmente por James Dunn (2003), fazem parte deste universo.

A dimensão desta pesquisa ainda pode ser vista em relação ao tempo e sua abrangência disciplinar. Esse tema possui um longo período, sendo iniciado no século XVII através de H. S. Reimarus e perdurando até os dias atuais. Diante disto, pode-se entender, como uma possibilidade de divisão, três fazes, cada qual com suas características e com seus representantes ${ }^{3}$.

A first quest, de acordo com Stegemann (2012, p. 107), desenvolveu-se durante o período de 1778-1906. Já para Theissen e Merz (2002, p. 21-24) de 196419104. Esse período é marcado pela pergunta sobre a autêntica historicidade de Jesus, ou seja, ou puramente histórico ou puramente sobrenatural. É nesse período que o evangelho de João começa a não ser considerado uma real fonte histórica, por David. F. Strauss (1808-1874).

Já a second quest, é envolvida por uma discussão maior que se resume a entender se o período de 1906-1973, pode ser considerado como uma pesquisa sobre o jesus histórico. Para alguns autores, esse período é considerado como um colapso da pesquisa sobre Jesus (THEISSEN; MERZ, 2002, p. 24), ou simplesmente como um período em que não houve pesquisa sobre Jesus (STEGEMANN, 2012, p. 107), tendo como um dos pesquisadores principais R. Bultmann. Todavia, apesar da "falta de material" é possivel concordar com Marsh (1997), citado por Stegemann (2012, p. 108):

Pela história da procura (por Jesus) fica claro que - estritamente falando - não existiu algo assim como um período de não procura, mas só um periodo que o caráter das fontes disponíveis foi radicalmente questionamento e a criatividade das primeiras comunidades cristãs foi acentuada [...].

Assim, dentro do período da second quest pode-se considerar o período em que alguns pesquisadores entendem que não houve busca pelo Jesus histórico. 
De tal modo, essa fase da pergunta sobre Jesus é marcada primeiramente pela pesquisa histórica de Jesus que se encontrava mais na retaguarda da exegese do Novo Testamento, e pela procura da conciliação entre a mensagem querigmática e a história de Jesus. Assim, enquanto a primeira fase foi marcada por uma forte oposição para com a mensagem da igreja, na segunda fase há uma tentativa de conciliação ${ }^{5}$.

A terceira fase, ou seja, a third quest, iniciou-se em 1973 e se estende até os dias atuais. É preciso ter em mente, desde já, como uma de suas principais características, que está fase está envolvida por uma transdisciplinaridade, o que supõe não só a necessidade da pesquisa, mas também sua importância, estando relacionada à história, sociologia, antropologia, teologia e, como uma das principais caraterísticas da third quest, arqueologia.

Embora, geralmente se pense que Jesus é um tema exclusivo da teologia, a terceira busca sobre o Jesus histórico, mostrou a importância do diálogo da teologia com outras ciências sociais e históricas, sendo um dos grandes avanços dessa pesquisa. Entrementes, a thirdquest mostra como a Teologia atua, ou até mesmo depende, dentro e das demais ciências sociais, ou seja, a Teologia deve ser pensada em meio as ciências sociais. Em outras palavras, "poderíamos dizer que não existe uma Teologia, a não ser numa determinada realidade social com suas complexidades específicas" (HILGERT, 1987, p. 40). A relação que os teólogos latino-americanos fizeram a partir do Jesus histórico comprova isso.

Um lado importante dentro dessa nova "atuação", a partir das demais ciências, é que a teologia passa por uma revisão e adequação de sua metodologia, ou seja, são repensados e aperfeiçoados os métodos exegéticos utilizados pelos teólogos, especialmente ao que tange o método histórico-crítico, método esse que foi influenciado pelo iluminismo, e teve alguns de seus princípios formulados no final do século XIX, pelo teólogo alemão Ernst Troeltsch (WEGNER, 1998, p. 31). Assim:

\footnotetext{
A terceira procura por Jesus encontra-se especialmente marcada também por novas abordagens metodológicas no contexto e em complemento ao elenco dos métodos tradicionais da crítica histórica. [...] Ao lado da metodologia histórica-religiosa, eles empregam também ofertas metodológicas e modelos antropológico(culturais), sociológicos e sócio-históricos, e a arqueologia da Terra Santa. Essa orientação interdisciplinar é típica para a thirdquest (STEGEMANN, 2012, p. 51).
} 
Entende-se, dessa maneira, onde atua a pesquisa sobre o Jesus histórico: não somente em uma disciplina, mas em uma perspectiva interdisciplinar, em busca do "histórico-crítico-social". Diante de tudo isso, é importante compreender o que é esse "Jesus histórico".

John Meier faz uma interessante afirmação em seu livro sobre esse tema: "O Jesus histórico não é o Jesus real. O Jesus real, não é o Jesus histórico" (MEIER, 1992, p. 31). Ao fazer essa afirmação, Meier está tratando sobre uma importante distinção entre a ideia de real e de histórico. Para ele, real refere-se a um certo tipo de completude do ser, nesse caso, da pessoa de Jesus, o que, segundo ele, é impossivel alcançar. É valido esclarecer que essa afirmação está diretamente ligada à discussão das fontes, e não sobre a existência ou não de Jesus. Assim, essa conclusão é baseada no fato de "as fontes de informação que subsistiram não registraram e nunca procuraram registrar todos ou mesmo a maioria dos atos e palavras do seu ministério público - sem falar do resto da sua vida" (MEIER, 1992, p. 32).

Esse fato leva a um questionamento ainda maior: se as fontes não tinham o objetivo de apresentar tudo sobre Jesus, como elas devem ser analisadas? Assim como a pergunta por Jesus, essa também não é uma pergunta nova, na realidade é nessa pergunta que está baseada boa parte da pesquisa. Em primeiro lugar ressalta-se que a maneira de olhar e pesquisar a fonte $Q$, evangelhos intracanônicos, evangelhos extracanônicos, testemunho da igreja, oralidade, perpassam a base da pesquisa sobre o Jesus histórico. E em segundo lugar, o questionamento sobre o que de fato é autêntico ou não traz à luz novas perguntas.

Aqui surge um paradoxo que, até que a arqueologia bíblica se desenvolva com novas descobertas, ou até mesmos novos escritos sejam descobertos, acompanhará os pesquisadores e pesquisadoras nessa área. Alguns critérios surgiram para que haja a identificação sobre a autenticidade dos ditos e feitos de Jesus. Para dar um exemplo dois critérios podem ser mencionados. O critério da dissimilaridade, que em resumo, entende que o que é autêntico é tudo aquilo que não pode ter sido criado pelo judaísmo ou pelo cristianismo primitivo; e o critério da plausibilidade, que entende que é autêntico aquilo que pode ser entendido à luz do contexto judaico ${ }^{6}$.

O grande paradoxo está no fato de existir critérios para identificação de autenticidade histórica sobre Jesus, mas ao mesmo tempo, esses critérios pode- 
rem levar a alguns entendimentos diferentes, que podem moldar o entendimento sobre Jesus em pequena ou larga escala. Stegmann resume bem esse fato: "praticamente cada pesquisador e pesquisadora de Jesus compila sua própria coletânea de palavras e ações autênticas de Jesus" (STEGEMANN, 2012, p. 163). Assim, mesmo que se possa fazer mais afirmações no atual momento da pesquisa, ainda assim, como afirma Crossan, corre-se o risco de ter um retrato diferente para cada exegeta (Crossan, 1994., p. 27).

Dessa maneira, Jesus histórico é uma construção científica, histórica e exegética. Dunn, resume isso da seguinte maneira: "O Jesus histórico é, corretamente falando, uma construção do século XIX e XX, usando dados fornecidos pela tradição sinótica, não o Jesus daquela época e não uma figura da história que podemos usar realisticamente para criticar o retrato de Jesus na tradição sinóptica" (DUNN, 2003, p. 126). ${ }^{7}$ Logo, ao tratar sobre a relação do Jesus histórico com os teólogos e teólogas na América Latina, refere-se a como eles e elas se relacionaram e utilizaram dessa pesquisa para uma construção teológica.

Portanto, o Jesus histórico é fruto do processo de uma construção científica, baseado em seu lugar, ou seja, na interdisciplinaridade. Assim, o Jesus histórico é um construto da ciência histórica, um resultado de trabalho científico, uma grandeza produzida discursivamente sobre a base de [mais de] um sistema de saber ou de ciência[s] específico[s] (STEGEMANN, 2012, p. 129). ${ }^{8}$

\section{Fé e história, Principio da teologia na AL}

Fé e história são temas que perpassam as mais variadas sociedades e religiões. A fé é vista dentro e através da história. É importante ressaltar que desde o início da pesquisa do Jesus histórico, especialmente na firstquest, essa é uma relação desafiadora. Reimarus, por exemplo, procurou fazer a distinção entre a pregação autêntica de Jesus e a fé dos apóstolos. David Strauss (1808-1874), retira o evangelho joanino do campo histórico e o coloca plenamente no campo querigmático, além de aplicar o conceito de mito ao Novo Testamento (THEISSEN; MERZ, 2002, p. 21-22).

Juan Luis Segundo, faz uma afirmação importante sobre fé. Embora ele não esteja falando de fé religiosa, que é o que será tratado aqui, e sim de uma fé antropológica, ele entende que a fé é pertencente a todo ser humano. "[...] a fé aparece como uma dimensão antropológica, ou seja, própria de todos [e todas], e 
de cada um dos homens [e mulheres]" (SEGUNDO, 1997, p. 17). Esse fato é importante na própria análise de fontes de Jesus. Dentro da análise das formas, que pretendia alcançar o Jesus histórico chegando até a fonte mais antiga, houve o reconhecimento de sua impossibilidade.

Essa impossibilidade se deu porque, de acordo com Stegmann, a análise das formas pode chegar somente à tradição mais antiga sobre Jesus, ou seja, "só até declarações que já sempre se encontravam entrelaçadas com a fé das comunidades mais antigas" (STEGEMANN, 2012, p. 171). Assim, até mesmo as tradições orais mais antigas continham em seus relatos a fé da comunidade que as transmitiam.

Dessa maneira, a relação fé e história vai desenvolver um papel significativo na construção de uma TLA. Não se pretende aqui discutir fé e história em relação à fonte, mas sim, entender a relação que fé e história possuem para o desenvolvimento de um olhar teológico para Jesus, ou até mesmo de uma "nova" fé em Jesus, olhar esse, enfatizado pelos teólogos latino-americanos. Boa parte das argumentações que serão apresentadas abaixo terão como base o livro de Jon Sobrino: Jesus Liberador (1991). ${ }^{9}$

\section{Fé e história sobre Jesus}

Jon Sobrino faz uma importante constatação sobre a relação entre fé e história, especialmente em relação ao conhecimento de Jesus. Para ele, Jesus Cristo é uma totalidade que possui dois lados. Um lado histórico (Jesus) e um lado transcendente (Cristo) (SOBRINO, 1991, p. 59-60). Logo, uma fé autêntica em Jesus não é somente uma fé que leva em consideração o lado transcendental, mas também o lado histórico. Ainda mais que esta fé está baseada na pessoa histórica de Jesus. Assim, Sobrino adverte que a fé em Cristo deve estar envolvida, do começo ao fim, na história (SOBRINO, 1991, p. 60).

Esse ponto leva Sobrino a fazer um importante questionamento sobre declarações de fé em Jesus. Para ele, as declarações de fé exercidas hoje estão moldadas, em sua maioria, por uma transcendência, ou o que ele chama de "afirmações-limite”. Em resumo, há nessas declarações dois lados, um lado divino e um humano. Contudo, o lado divino é sempre priorizado. Ou seja, as afirmações de fé em Jesus estão mais baseadas em sua divindade do que em sua história, e em alguns casos, somente divinalmente. 
É possivel observar um interesse acentuado nas afirmações teológicas, trazidas especialmente pelo apóstolo Paulo, sobre Jesus para sua construção teológica, ou cristológica. Assim, é enfatizada uma procura por entender Jesus mais a partir dos títulos de fé concedidos a ele pelos primeiros cristãos, tais como Filho do Homem, filho de Deus, Senhor, sumo-sacerdote, e Cristo, do que pela sua vida e ensino em meio a sociedade judaica, da qual ele fazia parte.

Esse aspecto pode ser visto, por exemplo, em uma das mais influentes obras sobre cristologia do Novo Testamento. Na obra, cristologia do Novo Testamento, de Oscar Cullman (2008), o autor divide o seu livro em quatro partes, mais a introdução. Dessa divisão somente a primeira parte e a introdução possuem algo de história de Jesus. Contudo, essas partes estão mais voltadas para a visão que os judeus e cristãos tinham de Jesus, do que para Jesus e sua obra como fundamento da cristologia. Enquanto isso, todos as demais partes voltamse para os títulos cristológicos e transcendentais dados a Jesus pelos primeiros cristãos.

É importante ressaltar, que não há uma crítica aos títulos divinais, ou a divinização de Jesus. Pela fé, acredita-se na divindade e senhorio de Jesus. Contudo, o ponto a ser entendido é "afirmar que Jesus é o Cristo, que é a expressão de o verdadeiramente divino e verdadeiro humano, são afirmações limites que, por sua natureza, exigem um caminho de conhecimento" (Sobrino, 1991, p. 60). ${ }^{10}$

Esse caminho de conhecimento passa pelo Jesus histórico. Essa relação pode ser bem entendida a partir de Sobrino que mostra como história e teologia em relação a Jesus devem ser entendidas. Primeiramente, de acordo com ele, não é possivel teologizar Jesus, ou entender a teologia de Jesus, sem primeiramente compreender e adentrar na sua vida, prática, significação social, luta social etc. E em segundo lugar, aprofundando a compreensão de Jesus, não é possível historizar a Jesus sem também teologizá-lo, sem apresentá-lo como a boa notícia de Deus. ${ }^{11}$

Dessa forma, história e fé para a teologia latino-americana não são mutuamente excludentes. A fé em Jesus, e as compreensões de fé, inclusive a sua cristologia do alto e toda sua ação pós ascensão, devem ser entendidas a luz do que realmente foi Jesus. O Jesus histórico é o ponto de partida de uma construção teológica na AL. Assim, o Jesus histórico é articulador da fé, das confissões de fé e dos atos de fé. Desse modo, compreender a mensagem do Jesus histórico, 
permite um fundamento para uma teologia latino-americana, que levará à uma cristologia, que faça diferença não só na igreja, como também na sociedade.

É diante disso, que Hilgert atesta:

Na questão do Jesus histórico estão implicados elementos cristológicos fundamenteis sempre e em qualquer lugar, mas cuja recuperação é particularmente urgente para a fé da Igreja latinoamericana, diante das cristologias tradicionalmente veiculadas nos manuais de piedade popular e diante das grandes opções pastorais a que se interpela (HILGERT, 1987, p. 74).

\section{Foco e desenvolvimento da teologia latino-americana a partir da relação fé- história}

A partir do entendimento de como teólogos latino-americanos relacionam fé e história, como no caso de Jon Sobrino, é importante observar qual o seu foco e quais são seus desenvolvimentos teológicos a partir dessa compreensão. Mas antes de aprofundar no assunto, é necessário compreender um dos principais desafios da TLA, embora, este assunto seja mais detalhado no próximo tópico.

Os desafios principais da Teologia Latino Americana iniciam-se na compreensão do problema do mundo. Sendo uma teologia, compreende o problema geral como "pecado", todavia, esse pecado gera problemas específicos, fundamentados especialmente em uma visão sociológica. Assim, para a TLA o mundo tem pecados sociais estruturais ${ }^{12}$ (CARVALHO; PY, 2017, p. 343). Neste sentido a autora Maria Clara Bingemer, resume bem um dos principais desafios sociais da TLA:

O que significa ser cristão em um continente de pessoas pobres e oprimidas? Estavam em jogo uma teologia alinhada à prática pastoral de uma igreja que queria se fazer livremente pobre, que se colocava ao lado do pobre, e que se comprometia com a libertação de todas as formas de opressão e marginalização (BINGEMER, 2017, A igreja do Concílio Vaticano II e a teologia latinoamericana)

A opressão presente nos países latino-americanos foi catalizadora para uma visão sobre uma nova necessidade teológica. Assim, é possível perceber uma grande diferença entre produções europeias e norte-americanas e produções latino-americanas. Como Bingemer deixou claro anteriormente, a América Latina viu-se necessitada de uma teologia pastoral, de uma teologia aplicada às necessidades cruciais do povo latino-americano. 
O desenvolvimento de uma aplicação teológica aconteceu a partir do próprio Jesus histórico, e como já visto antes, a partir da compreensão social do povo, o que fez com que os teólogos latino-americanos buscassem compreender a realidade social a partir das ferramentas proporcionadas pelas ciências sociais (HIGUET, 1989, p. 47). Diante disso, o caminho que a TLA segue, é tanto a de uma construção cristológica a partir do Jesus histórico, e essencialmente uma cristologia aplicada às necessidades do povo latino.

Entender o porquê de Jesus ser o caminho para uma cristologia latinoamericana não é difícil. Em resumo, na pessoa de Jesus e em sua posição social encontrou-se uma intrínseca proximidade nas relações políticas, sociais, e antropológicas dos homens e mulheres que vivem na América Latina. Dessa maneira, Sobrino esclarece que nos últimos 20 anos de pesquisa (período da década de 70-90) as reflexões cristológicas estão envoltas do Jesus histórico, além de mostrar como os principais nomes da TLA, tais como Gustavo Gutierrez e Leonardo Boff, criticaram uma cristologia sem história, ou tão somente sobrenatural, e voltaram-se a apresentar uma cristologia a partir do Jesus histórico (Sobrino, 1991, p. 71).

Assim, Gutierrez destaca:

Aproximar-se ao homem Jesus de Nazaré no qual Deus fez-se carne, indagar não somente por seu ensino, e sim por sua própria vida, que é o que dá a sua palavra contexto imediato e concreto, é uma tarefa que se impõe cada vez com maior urgência (GUTIÉRREZ, G. 1971 apud SOBRINO, 1991, p. 71).

A partir dessa urgência, os teólogos latino-americanos procuraram, portanto, produzir teologias que estão comprometidas com o Jesus histórico. Dessa forma, entender Jesus como um judeu, nascido em Nazaré, que como carpinteiro vivia à margem da sociedade, sofrendo exploração do império romano, e através disso possuindo uma mensagem a favor da vida e das minorias, e expressando a necessidade de justiça social, contra formas de intolerância, preconceitos, hipocrisias religiosas, patriarcalismo e exploração econômica, concedeu à TLA um de seus principais termos: libertação.

É a partir desta compreensão que Gutierrez expressa por exemplo, que uma espiritualidade da libertação deve ser uma vivência que leva à comunhão com o Senhor e com todos os homens, e isso, é um dom (GUTIERREZ, 1972, p. 
269). Assim, o Jesus histórico, para os teólogos latino-americanos, é a base de uma cristologia. Logo:

A cristologia latino-americana retoma propriamente o mesmo "método", coloca-se comunitariamente diante do Senhor histórico e ressuscitado e pergunta-se por seus compromissos e esperanças diante de hoje de sua própria vida comunitária e diante dos desafios históricos a que o Senhor a envia (HILGERT, 1987, p. 70).

Entender a necessidade de uma construção cristológica a partir do Jesus histórico é algo fundamental para o desenvolvimento da TLA. Contudo, os teólogos latino-americanos não procuraram construir teologias tão somente teóricas, mas uma de suas principais características é a aplicação dessa teologia à sociedade. Assim, muito mais que apresentar uma história de Jesus de Nazaré como base de uma construção cristológica, a teologia latino-americana se propôs a apresentar uma história de Jesus de Nazaré para o nosso ser cristão, e como Hilgert assevera, dentro da história concreta do continente latino-americano (HILGERT, 1987, p. 62).

Rubem Alves compreende isso como um dos principais fatores, e pontos de partida para a Teologia Latino-Americana. Segundo ele, é preciso que a teologia na América Latina deve partir de uma nova "linguagem", assim: "a necessidade dessa nova linguagem se derivava do compromisso concreto de muitos cristãos [e cristãs] com a tarefa de tornar o homem historicamente liberto dos poderes que o mantêm escravizado" (ALVES, 1987, p. 215).

Teologia da libertação, teologia da missão integral, teologia feminista, para citar alguns exemplos de teologias latino-americanas, não são teologias com perspectivas somente teóricas. Há, obviamente, um grande esforço acadêmico por parte dos teólogos latino-americanos, não somente por meio da teologia, mas em conjunto com outras ciências sociais de interpretação tanto de sua sociedade e contexto, a partir de métodos sociológicos e antropológicos, como uma interpretação bíblica, destacando-se o método histórico social.

Contudo, esses mesmos teólogos procuram avançar saindo do campo teórico e chegando ao campo prático. Em outras palavras, o objetivo dos teólogos latino-americanos é proporcionar uma teologia que faça a diferença em meio a opressão, desigualdade e injustiça vivenciados em sua sociedade. Dessa forma, "é o contexto de opressão e dependência em todos os níveis da vida, despertando 
o seu correlato oposto - a libertação - que propicia à cristologia na AL pensar e amar a Jesus Cristo como Libertador.” (HILGERT, 1987, p. 142).

Mais uma vez, isso está pautado no próprio Jesus histórico. O autor de Mateus, a partir de uma fonte exclusiva, mostra que Jesus associava justiça social a entrada no reino dos céus. Segundo Jesus, aqueles que serão benditos, são aqueles que lhe deram de comer enquanto passava fome, de beber enquanto passava sede, o hospedaram quando era forasteiro, enquanto estava nu o vestiram, preso foram-lhe ver, e isso é feito à Jesus quando praticado aos "pequeninos" (Mt 25.34-40).

Logo, para a TLA, é necessária uma teologia que esteja pautada, especialmente, no princípio de justiça social. Libertar o oprimido e a oprimida, opondo-se ao opressor e a opressora, seja ele uma pessoa ou o sistema. Dessa forma, faz-se necessário uma aplicabilidade teológica, que passa de conceitos sobre fé, e avança para uma prática de fé. A TLA, à luz das palavras de Hilgert, quer comprometer-se com a libertação dos oprimidos e oprimidas e com a criação de uma nova história, ao menos mais próxima do plano de Deus. Plano esse, vale ressaltar, que além da libertação do pecado, volta-se para a justiça social no meio da sociedade atual.

\section{TLA e sociedade}

Teologia da libertação, teologia da missão integral, teologia feminista, teologia negra etc. são teologias que perpassam e se destacam na América Latina, embora nem todas tenham sido iniciadas no contexto latino-americano. Todas possuem contribuições fundamentais em seus desenvolvimentos em solos latinoamericanos e se apresentam necessárias no contexto referido.

Como visto anteriormente, essas teologias possuem uma preocupação essencial nos tempos e contextos atuais: uma preocupação com pessoas, seu modo de vida, seus desenvolvimentos sociais, suas lutas e vitórias. Isso vem baseado no Jesus histórico, ou seja, a compreensão de que Jesus em seu tempo possuiu essa preocupação e sua mensagem era uma mensagem que alcançava as pessoas, especialmente as pessoas oprimidas econômica, social e religiosamente.

Assim, a mensagem e vida de Jesus se voltava para os pobres e marginalizados na sociedade, se voltava para os "pecadores"que eram excluídos pelos líderes dos principais grupos judaicos, se voltou não para as grandes cidades, mas para as vilas onde a opressão econômica causada pelo império romano era mai- 
or, concedeu voz e agregou a seus grupos mulheres em meio a uma sociedade plenamente patriarcal.

As teologias latino-americanas, a partir disso, trazem uma teologia para as pessoas que se faz essencial no contexto latino-americano. Isso pode ser visto, por exemplo, na decisão feita na reunião de Medellín em 1968, que definiu que: pri-meiro, deveria haver uma conexão entre evangelização e luta contra injustiça social; segundo, a teologia deveria estar conectada com a realidade social e política de seu contexto; e por fim, as comunidades eclesiásticas deveriam se inspirar na Bíblia para transformar as condições sociais injustas (Bingemer, 2017: Os pobres como berço de trabalho teológico para a Teologia da Libertação e para a Teologia Feminista). Mas por que isso é tão importante para a América Latina?

A resposta provém tanto da história quanto da atualidade. Em primeiro lugar, é preciso relembrar que o "início" da América Latina foi marcada por grande exploração. Essa exploração deu-se em diversos aspectos, mas entre eles, estava a ganância europeia. Eduardo Galeano, apresenta a ideia que perpassava as mentes europeias chegadas na América: "Porque do ouro se faz tesouro, e quem o tem faz o que quiser no mundo e até leva as almas para o Paraíso" (GALEANO, 2012, p. 15).

A partir dessa afirmação de Galeano, pode-se perceber como a busca pela riqueza, e vale ressaltar o aspecto religioso que apresenta essa riqueza sendo capaz de levar até o paraíso, influenciou todo o início de opressão imposto pelos europeus aos autênticos latino-americanos. Além disso, retirar nesse período a Europa se desenvolvia a partir das riquezas encontradas nas américas. Como assevera Galeano: "Os metais arrebatados aos novos domínios coloniais estimularam o desenvolvimento europeu e até se pode dizer que o tornaram possivel" (GALEANO, 2012, p. 25).

Haja vista essas afirmações percebe-se que o povo latino-americano desde a chegada dos europeus viveu sobre opressão. O que é necessário ressaltar neste momento é que essa opressão não se extinguiu, mas evoluiu juntamente com a evolução que a sociedade passa constantemente. Nesse caso, hoje a afirmação de Galeano de que a América era um negócio Europeu (GALEANO, 2012, p. 26), não precisa ser excluída, apenas atualizada, isso leva ao segundo entendimento.

Todo esse processo e espírito ganancioso e consequentemente opressor, visto no "início" da história das américas, perpassou a história e é presente ainda hoje. Contudo, como mencionado anteriormente, isso não se dá da mesma ma- 
neira, mas é visto especialmente em meio a pobreza econômica e cultural que é consequência dessa opressão, e o que deve chamar a atenção, não é mais somente uma opressão de fora para dentro como ocorrera anteriormente, ou seja, Europa à América, mas isso é visto entre o próprio povo, por falta de uma consciência de classe.

Junto com a pobreza socioeconômica há também a pobreza cultural, que é igualmente difícil e pesada. Há opressão e discriminação racial, étnica e sexual. Além disso, é comum que muitas mulheres e povos indígenas enfrentem maiores dificuldades ao longo da vida devido ao seu gênero e à sua origem. Essa dificuldade a mais depende da realidade socioeconômica e a exacerba (BINGEMER, 2017, Os pobres como sujeito e método)

Esses fatos relatados até aqui, de uma opressão europeia e uma continuação desse sentimento/espírito em meio e dentro do povo, deve levar à compreensão do que Jessé Souza chama (embora esteja falando especificamente do Brasil, aplica-se a América Latina) de herança escravocrata. Um exemplo disso é sua afirmação de que o Brasil adentrou o século XX em meio à continuação de padrões valorativos herdadas sob uma máscara moderna do escravismo (SOUZA, 2017).

Esta realidade perpassa a $\mathrm{AL}$, sendo causador de cada vez mais opressão e injustiça. Fazendo uma conexão com a pobreza presente no contexto tratado, deve-se lembrar que a pobreza não está ligada à sorte ou à preguiça, contrariando assim, o argumento meritocrático, mas, "é devida a injustiças estruturais que privilegiam poucos enquanto marginalizam muitos" (BINGEMER, 2017). Logo, diante dessas circunstâncias, é preciso lembrar de um dos principais causadores de tamanha injustiça. "O capitalismo se liga mais à cultura brasileira silenciado a sua exploração e permitindo menos resistência a sua brutalidade" (CARVALHO; PY, 2017, p. 359).

A TLA, volta-se para tudo isso com muita preocupação. Souza assevera que a herança escravocrata, é usada para oprimir todas as classes populares (SOUZA, 2017, Os conflitos de classe no Brasil moderno). E aqui jaz, para a TLA, sua principal área de atuação. Dessa forma, assim como Jesus atuou teológica e socialmente em meio a um contexto de opressão e injustiças, é o dever da teologia atuar e procurar mudar essa realidade. Talvez, faça-se necessário uma atualização teológica da afirmação de Paulo Freire, assim, se a teologia não for libertadora, o sonho do oprimido é tornar-se opressor. 
Assim, o porquê da pergunta postulada acima é parcialmente respondido. Em meio a uma sociedade que vivencia constantemente, e de uma certa maneira normalmente, injustiças, opressão, intolerância, racismo, discriminações, feminicídios, entre tantas outros que poderiam ser citados aqui; é crucial em primeiro lugar, uma teologia que esteja primeiramente baseada em Jesus, tanto historicamente como transcendentalmente (não se pode teologizar Jesus sem historizálo, e nem se pode historizá-lo sem teologizá-lo); e em segundo lugar, uma teologia que esteja pronta à aplicar esse Jesus às necessidades de seu contexto político e social.

De tal modo, Alves resume o dever teológico na América Latina: "O elemento primário, do qual ela nasce e para o qual aponta, consiste na política da liberdade em processo, na qual a liberdade para o futuro e a liberdade para a vida devem ser encontradas. Sua significação é profética" (ALVES, 1987, p. 217). Portanto, os desafios de alcançar a autêntica libertação, continuam em meio as TLA's e na sua relação com a sociedade. Por exemplo, embora haja teologia negra, não é visto no Brasil instituições que apoiem deliberadamente o pensamento teológico negro (Carvalho; PY, 2017, p. 362).

\section{Considerações finais}

Maria Bingemer relata que um dos conceitos mais importantes para a TLA é uma teologia enraizada na realidade (BINGEMER, 2017). Como visto anteriormen-te, essa realidade se apresenta em dois níveis: a realidade de Jesus e a realidade do povo latino-americano. Dessa maneira, Jesus e a sociedade atual estão em estreita relação para a TLA. O Jesus histórico que baseia o Cristo, e dessa maneira Jesus Cristo deve ser um Jesus Cristo para as pessoas, aplicado as suas necessidades, especialmente em meio a injustiças vivenciadas na América Latina.

O fato de a TLA relacionar-se com duas realidades impõe a ela um duplo desafio. Primeiramente, discutir Jesus histórico, e especialmente como ponto de partida cristológico, é um desafio imposto constantemente. Dessa forma, é preciso um auto exame de como ela vê, analisa e pesquisa Jesus, e juntamente com isso, é necessário observar os pressupostos que moldam sua visão e consequentemente sua pesquisa sobre Jesus.

Isso acarreta implicações a seu segundo desafio: a aplicação dessa teologia à sociedade. Isso vai desde sua relação com as demais ciências sociais, como as 
implicações que a própria sociedade exige por si mesma. De tal maneira, assim como a auto análise sobre a visão de Jesus deve ser constante, a análise de sua visão das sociedades, deve ser permanente.

Sendo assim, em meio aos seus desafios, é importante observar que a TLA possui importância crucial na luta por uma sociedade melhor. É valido observar também, que como toda teologia, a TLA possui seus erros e acertos, apesar disso, sua necessidade, implicações e contribuições às sociedades, podem ser vistas claramente. Em meio as diversas teologias importantes neste contexto, os desafios continuam sendo imensos.

Por fim, é valido reafirmar a importância e a necessidade da pesquisa do Jesus histórico nos tempos atuais. Essa é uma pesquisa que não se esgota. Quanto mais próximo for possivel chegar em Jesus, não somente em conceito, mas também em práticas, torna-se possivel a visão e a luta por uma sociedade mais justa e menos desigual. Assim, esse Jesus histórico, que está baseado na interdisciplinaridade e é resultado dela, deve ser encorajado, especialmente nos meios teológicos (sejam faculdades ou seminários). É inegável ainda, que a utilização feita pelos teólogos latino-americanos, do Jesus histórico é crucial para o desenvolvimento de uma teologia mais humanitária, de tal modo que, é de importância crucial para a sociedade desigual e injusta de todos os tempos.

\section{Referências bibliográficas}

ALVES, R. Da esperança. Campinas, SP: Papiros, 1987.

BINGEMER, M. C. Teologia Latino-Americana: raízes e ramos. Kindle. Rio de Janeiro;Petrópolis: PUC-Rio; Vozes, 2017.

CARVALHO, C.; PY, F. Teologia da Libertação: História, Temas e Nomes. CrossCur-rents, v. 67, n. 1, Março 2017. p. 340-364.

CROSSAN, J. D. O Jesus histórico: a vida de um camponês judeu no mediterrâneo. Rio de Janeiro: Imago, 1994.

CROSSAN, J. D. O Nascimento do Cristianismo: o que aconteceu nos anos que se seguira à execução de Jesus. São Paulo: Paulinas, 2004.

CUlmann, O. Cristologia do Novo Testamento. São Paulo: Hagnos, 2008.

DUNN, J. D. G. Jesus Remembered. Cambrigde U. K.: [s.n.], 2003.

GAlEANO, E. As veias abertas da América Latina. Porto Alegre: L\&PM, 2012.

GEERTZ, C. A interpretação das culturas. Rio de Janeiro: LTC, 2008.

GUTIERREZ, G. Teología de la Liberacion: perspectivas. Salamanca: Seguime, 1972. 
HIGUET, E. A. Medellín e o método da teologia da libertação. Estudos da Religião.São Paulo: UMESP, n. 6, 1989. p. 45-74.

HILGERT, P. R. Jesus histórico: ponto de partida da cristologia latino-americana. Petrópolis: Vozes, 1987.

MEIER, J. P. Um Judeu Marginal: repensando o Jesus Histórico. Rio de Janeiro: Imago, 1992.

SCHEWEITZER, A. A busca do Jesus histórico: um estudo crítico de seu progresso. São Paulo: Novo século, 2003.

SCHMITZ, E. D. Conhecimento, Experiência, Ignorância. COENEN, L.; BROWN, C. Dicionário internacional de Teologia do Novo Testamento. São Paulo: Vida Nova, v. $1,2000$.

SEGUNDO, J. L. A História perdida e recuperada de Jesus de Nazaré: dos sinótico a Paulo. São Paulo: Paulus, 1997.

SOBRINO, J. Jesús Cristo en América Latina: su significado para le fe y la cristología. San Salvador: UCA/Editores, 1982.

SOBRINO, J. Jesus Liberador: Lectura histórico-teológica de Jesus de Nazaret. $2^{a}$. ed. Madrid: Editora Trotta, 1991.

SOUZA, J. A Elite do Atraso: da escravidão à Lava Jato. Kindle. ed. Rio de Janeiro: Leya, 2017.

STEGEMANN, W. Jesus e Seu Tempo. São Lepoldo: Sinodal; EST, 2012.

THEISSEN, G.; MERZ, A. O Jesus Histórico: um manual. São Paulo: Loyola, 2002.

WEGNER, U. Exegese do Novo Testamento: manual de metodologia. $7^{\circ}$ ed. São Leopoldo: Sinodal, 1998.

1 A partir daqui se usará essa sigla como abreviação de "teologia latino-americana". É importante ressaltar que TLA é entendida nesse artigo, como as diversas teologias produzidas, aprofundadas e que possuem suas características em relação ao contexto latinoamericano. Assim, TLA não se refere aqui à uma teologia específica, mas as diversas teologias desenvolvidas por teólogos latino-americanos em intrínseca relação com o contexto social, econômico e político da América Latina.

2 Para uma discussão sobre a utilização do termo Jesus real cf. Stegemann, 2012. p. 115-124; Meier, 1992.

${ }^{3}$ Seguiremos a divisão de três momentos da pesquisa sobre o Jesus histórico, first, second e third quest. Contudo, reconhecemos as demais alternativas para a divisão das fases dessa pesquisa. Cf. Stegemann, 2012.

${ }^{4}$ Interessante ressaltar que para esses autores, nesse periodo existiram duas fases diferentes de pesquisa.

${ }^{5}$ Compreendemos que a abrangência e a discussão das fases da pesquisa sobre o Jesus histórico são mais profundas e abrangentes do que está resumido nos parágrafos deste artigo, envolvendo temas como "liberalismo", "nazismo", "escatologia", etc. Assim, para aprofundamento nessas pesquisas cf. Scheweitzer, 2003; Stegmann, 2012. 
6 Para aprofundamento nesses critérios cf. Theissen; Merz, 2002; Stegemann, 2002.

${ }^{7}$ Dunn, 2003, p. 126. "[...] the 'historical Jesus' is properly speaking a nineteenth- and twentieth-century construction using the data provided by the Synoptic tradition, not Jesus back then and not a figure in history whom we can realistically use to critique the portrayal of Jesus in the Synoptic tradition" (grifo nosso).

${ }^{8}$ Stegemann, 2012, p. 129. (Acréscimo próprio).

${ }^{9}$ Sobrino, 1991. Esse livro se faz importante nessa pesquisa, pois Sobrino resume e proporciona pontos fundamentais para essa discussão.

10 SOBRINO, 1991, p. 61. "Afirmar que Jesús es el Cristo, que es expresión de lo verdaderamente divino y verdaderamente humano, son afirmaciones-límite que, por su naturaleza, exigen un camino del conocimiento". (Tradução nossa).

${ }^{11}$ SOBRINO, 1982. p. 128.

12 Esta visão aprofunda-se especialmente quando se entende o Deus YWHW no AT, e sua ação em Jesus no NT, como ações que buscavam justiça social, sendo assim, Deus é um Deus de justiça social. Para aprofundamento no assunto cf. Crossan, 2004.p. 221-250.

Recebido em 12/02/2021

Aceito para publicação em 27/03/2021 


\section{Estados de consciência misticos e Transe capoeirano: uma interpretação da obra de mestre Decanio à luz do pensamento de William James}

Mystical states of consciousness and capoeira trance: an interpretation of the work of master Decanio in the light of William James' thought

Cicero Cunha Bezerra*

do: $\underline{\text { https://doi.org/10.29327/256659.12.2-17 }}$

Resumo:

As figuras dos mestres Bimba e Pastinha dominam, no geral, os interesses e análises sobre a capoeira, no entanto, dentre os vários mestres que compõem o universo da capoeiragem, há um que, no meu entender, estabelece uma visão extremamente particular da prática da capoeira, a saber: mestre Decanio (1923-2012). Esse artigo tem, portanto, o objetivo de compreender, à luz do pensamento de William James, em especial das suas reflexões presentes em suas conferências sobre os estados místicos de consciência, em que medida é possivel sustentar o caráter místico do transe capoeirano, proposto por Decanio, como uma forma particular de êxtase que ocorre pela interação entre três níveis que constituiriam o psíquico humano: consciente, inconsciente e estados modificados de consciência.

Palavras-chave: Decanio. Capoeira Regional. William James. Transe.

Abstract:

The figures of masters Bimba and Pastinha dominate, in general, the interests and analysis of capoeira.However, among the various masters that make up the universe of capoeira, there is one that, in my understanding, establishes an extremely particular view of capoeira practice, namely: master Decanio (1923-2012). This article, therefore, aims to understand, in the light of William James' thinking, especially his reflections present in his lectures on the mystical states of consciousness, to what extent it is possible to sustain the mystical character of the capoeira trance, proposed by Decanio, as a particular way of ecstasy that occurs through the interaction between three levels that would constitute the human psyche: conscious, unconscious, and modified states of consciousness.

Keywords: Decanio; Regional Capoeira; William James; Trance.

"Doutor em Filosofia pela Universidad de Salamanca (Espanha), Professor Titular do Departamento de Filosofia e dos Programas de Pós-Graduação em Ciências da Religião e Filosofia da Universidade Federal de Sergipe. Pesquisador de Produtividade do CNPq. Email: cicerobezerra@hotmail.com 


\section{Introdução}

O berimbau é muito espiritual. O som do berimbau vem de dentro. E toda a conexão - a energia está no chakra aqui [Naná indica seu tórax e cavidade pulmonar] (NANÁ VASCONCELOS, 2007, p. 50)

A capoeira, como manifestação cultural brasileira, desperta múltiplos interesses em várias áreas do conhecimento. Aspectos sociais, estéticos, educacionais, dentre outros, estimulam uma vasta produção bibliográfica em diversas linguas e formatos (textos, podcast, vídeos, etc.). Angelo Augusto Decanio Filho, mestre Decanio, não é somente um dos mais importantes e exímios capoeiristas "filhos de Bimba". Médico de formação, conhecedor da fisiologia humana, leitor de tradições como a budista, a teosófica, a cristã e a candomblecista, Decanio propõem uma visão do humano a partir da unidade entre corpo, alma e espírito focando no desenvolvimento das capacidades fisico-motoras e, fundamentalmente, espirituais do ser humano.

Uma leitura atenta das suas obras A herança de Mestre Bimba, Filosofia e lógica africanas (1998) e Transe capoeirano, um estudo sobre estrutura do ser humano e modificações de estado de consciência durante a prática da capoeira (2002), ambas analisadas nesse estudo, permite vislumbrar sua complexa interpretação dos elementos técnico-práticos da capoeira associados a elementos religiosos, em particular oriundos do Candomblé e do Budismo.

Tendo iniciado sua prática no Centro de Cultura Física Regional em 1938, sua influência na academia do mestre é pública e reconhecida por todos que com ele conviveram. Segundo o testemunho de Hellio Campos (Mestre Xaréu), Decanio não somente era "um cobra" na arte da capoeiragem, possuindo todas as qualidades de um bom capoeirista, mas, também, como cirurgião, com destacada atuação no campo da medicina como conferencista em eventos nacionais e internacionais (CAMPOS, 2009, p. 280). Em sua obra "A herança de mestre Bimba: Filosofia e lógica africanas" é o próprio Decanio que revela sua participação direta em aspectos internos da academia que vão desde a criação do símbolo da Capoeira Regional até consultas pessoais feitas pelo o seu fundador. Basta dizer que Decanio foi, de todos os alunos, o único a receber, das mãos de mestre Bimba, o grau máximo: o lenço branco.

A grande característica dos escritos de Decanio está no fato dele não se limitar a comentar os aspectos históricos, técnicos ou culturais da sua arte. Ele 
vai mais longe. O que de fato lhe interessa é definir uma visão da capoeira na qual o físico, o mental e o espiritual convergem em uma unidade que tem como pilar uma experiência extática de comunhão que se alinha, perfeitamente, ao que o filósofo William James definiu como estados místicos de consciência (mystical states of consciousness).

Eugene Taylor observa que a compreensão jamesiana de sistemas de crenças conflitantes, à luz da filosofia pragmática, assim como suas reflexões pioneiras sobre as relações entre o cérebro e a mente, com consequências para a ideia de consciência, tiveram impacto profundo e o tornaram-se marco decisivo nos estudos sobre psicologia da religião. Basta dizer que nenhuma obra é mais influente nesse campo do que Varieties of Religious Experience (TAYLOR, 1996, p. 82). Para este trabalho, me interessa somente destacar, da obra de James, as conexões entre estados místicos da consciência e o transe como expressão da unidade na qual categorias como "sujeito" e "objeto", "contemplante" e "contemplado", "humano" e "divino" se desfazem na experiência mística.

Para tanto, visando uma melhor compreensão do tema aqui proposto, divido esse artigo em três partes: a) na primeira, exponho a ideia jamesiana de estados místicos de consciência em seus aspectos centrais presentes em suas conferências XVI e XVII intituladas de Mysticism e publicadas, por primeira vez, em 1902 em sua obra Varieties of Religious Experience; b) em um segundo momento, apresento a noção de "transe capoeirano", como é desenvolvida por mestre Decanio em sua obra de mesmo nome Transe capoeirano, um estudo sobre estrutura do ser humano e modificações de estado de consciência durante a prática da capoeira (2002) para, em seguida (c) apresentar os resultados obtidos, a partir de ambos autores, que permitem sustentarmos a presença de elementos místicos que fazem da capoeira, em consonância com o que sustenta William James, uma experiência de transe espiritual (transport) que, no caso do pensamento de Decanio, se dá como unidade entre jogador e jogo.

\section{a) W. James os estados místicos de consciência}

Em suas duas Conferências sobre misticismo James estabelece quatro pontos centrais para a compreensão do que ele classifica como um estado mental (state of mind) místico (mystical) são eles:

1) Inefabilidade (Ineffability) - definida a partir da "negatividade", isto é, do reconhecimento do seu caráter indizivel, a inefabilidade aproxima os estados 
místi-cos da consciência à afetividade, ou seja, a um experimentar que escapa a toda expressão e, consequentemente, aos estados intelectuais.

2) Qualidade noética (Noetic quality) - sem contradizer ao aspecto de "afetividade" que caracteriza aos estados místicos, o estatuto de conhecimento e, mais, de um conhecimento verdadeiro é comum ser atribuído pelos que vivenciam experiências místicas. Ainda que o intelecto discursivo cesse diante da inefabilidade, o místico não abre mão do valor noético que se expressa como uma "penetração na verdade profunda e insondável ao intelecto discursivo" (JAMES, 2002, p. 295).

3) Transitoriedade (Transiency) - os estados místicos são sempre descritos como efêmeros. James ainda arrisca a limitá-lo a, no máximo, duas horas. São momentos específicos de iluminação ou êxtase que escapam a qualquer controle.

4) Passividade (Passivity) - ainda que existam práticas espirituais que prescrevam determinados exercícios, rituais, atividades corporais etc., há um elemento de supressão da vontade que define os estados místicos como "irresistível", "incontrolável” e que permanece em seus desdobramentos como uma certa recordação fruto de uma "modificação da vida interior" (JAMES, 2002, p. 296). William James aproxima essas características a certas experiências como a escrita automática e o transe hipnótico, no entanto as distingue dos estados místicos precisamente por estas últimas não manterem, após a interrupção, recordações ou consequências transformadoras para o indivíduo.

Estes quatro aspectos constituem o que James nomeia de "grupo de estados místicos" (mystical group), ou seja, estados de consciência peculiares que justificam um estudo cuidadoso que o mesmo realiza tomando, em um primeiro momento, as experiências que não se relacionam diretamente com aspectos religiosos, mas que eclodem da vida cotidiana comum. Mediante uma predisposição mental é possível, segundo James, que diante de uma música, um poema ou mesmo palavras, antes não percebidas, indivíduos possam experimentar estímulos que despertam o que ele chama de suscetibilidade mística (mystical susceptibility).

Um outro aspecto importante sublinhado por James e que aparecerá na obra de Decanio como uma característica definidora do transe capoeirano se refere a um estado mais profundo que consiste, entre outras coisas, na eliminação das relações espaço-temporais graças a dissolução do "eu consciente" seja por 
uso de anestésicos ou "pela sensação da presença imediata de Deus" (JAMES, 2002, p. 304). James cita, entre outras fontes literárias, um fragmento de Walt Whitman como exemplo de uma experiência mística marcada pela unidade com a natureza: "Rapidamente surgiu e se espalhou ao meu redor a paz e o conhecimento que supera todos os argumentos da terra" (WHITMAN apud JAMES, 2002, p. 307).

Trata-se, assim, da ideia da unidade sujeito/natureza que se expressa, na análise de James, em vários níveis e formas de classificações e que perfaz desde narrativas classificadas como patológicas até tradições religiosas. À parte dos exemplos citados por James o que interessa aqui destacar, são os efeitos morais e físicos que as experiências místicas podem propiciar aos que delas desfrutaram. Diz James: “ Para emitir um juízo espiritual de tais estados, não devemos contentar-nos com a terminologia médica superficial, mas devemos inquirir seus frutos para a vida" (JAMES, 2002, p. 320). Para James, ao contrário de debilidade e inatividade indivíduos como Inácio de Loyola, Teresa D’Ávila, Juan de la Cruz, como também destaca Michel Serres, eram pessoas de grandes preparos físicos:

Desconfio que as análises patológicas do misticismo são sempre ignorantes e maldosas, e isto porque exercem sua força sobre uma fragilidade doentia e sua ação sobre a passividade (...). De corpos atléticos e sem nunca adoecerem, santa Teresa d'Ávila e são Francisco de Assis caminhavam centenas de quilômetros pelos relevos áridos da Espanha e da Itália, espargindo-os com fundamentos laboriosos, porque eram sobejamente poderosos e exímios conhecedores das técnicas do corpo (SERRES, 2004, p. 21).

Na mesma linha afirma James:

Os grandes místicos espanhóis, que levaram o hábito do êxtase tão longe como nenhum outro podia levá-lo, parecem ter mostrado, a maioria deles, um espírito e uma energia indomáveis, se consideramos os transes nos quais se deleitavam (JAMES, 2002, p. 320).

Como se pode observar, para ambos filósofos, como dirá, uma vez mais, Serres: "A santidade sucede à saúde como conhecimento e ação" (SERRES, 2004, p. 21). Estes são os pontos que gostaria de destacar na análise jamesiana dos estados místicos de consciência e suas consequências morais e práticas. Estes são dois aspectos importantes que serão destacados no olhar do mestre Decanio 
em suas reflexões sobre o transe capoeirano. Dito isso, passo para o segundo tópico deste trabalho.

\title{
b) Decanio e as modificações de estado de consciência durante a prática da capoeira
}

Na epigrafe que abre sua obra Transe capoeirano: um estudo sobre a estrutura do ser humano e modificações de estado de consciência durante a prática da capoeira, dedicada à sua companheira Bel, Decanio expressa algumas ideias que me parecem fundamentais antes de adentrar na análise do seu texto:

\author{
Durante toda a minha existência \\ Pregressa, atual e futura \\ Você tem sido, é e continuará eternamente \\ O elo entre o Mundo Manifesto e o Oculto. \\ Como Estrela Guia \\ A me conduzir pelo Labirinto Cósmico On- \\ de habita o SER \\ Imagem sagrada do Criador Temporá- \\ ria e periodicamente Manifestada em \\ cada Encarnação \\ Em busca do retorno à Perfeição! \\ Este é o fruto deste reencontro \\ De nossa colaboração e troca de experiências! \\ Que Deus continue a manter A \\ FORÇA, A LUZ e O AMOR \\ Imanentes à nossa geração! (FILHO, 2002, p. 3)
}

Penso que temos um resumo completo da visão de Decanio do mundo como um ciclo continuo que expressa um ato criador primeiro. Ato este que pode ser tomado como princípio e fim de um brotar que instaura, entre o manifesto e o oculto, a unidade entre o particular e o universal. Em sendo assim, temos: a) Mundo manifesto e o Oculto; b) Labirinto Cósmico onde habita o SER; c) o Cosmos como imagem do Criador; d) Encarnação como manifestação da imagem sagrada do Criador.

As consequências desta visão se evidenciam logo no primeiro parágrafo da obra quando o mestre afirma:

O capoeirista deixa de perceber a si mesmo como individualidade consciente, fusionando-se ao ambiente em que se desenvolve o jogo de capoeira, passa a agir como parte integrante do quadro ambiental e procede como se conhecesse ou percebesse simultaneamente passado, presente e futuro (tudo que ocorreu, ocorre e o- 
correrá a seguir), ajustando-se natural, insensível e instantaneamente ao processo atual (FILHO, 2002, p. 5).

Passado, presente e futuro congregados no instante "já" de um tempo marcado pelo ritmo-melodia ijexá. Muniz Sodré, em seu livro Pensar Nagô, destaca o elemento "bélico" da dança e ritmos africanos que, posteriormente, assumiram formas litúrgicas: "Numa dinâmica regida pelo axé, como é o caso da liturgia afro, a música é primordialmente vibratória, orientando-se pelas modalidades da execução rítmica, do canto e da dança, em que a percussão é fundamental (SODRÉ, 2017, p. 141).

É precisamente na unidade que o praticante, segundo Decanio, "alcança um estado modificado de consciência" (FILHO, 2002, p. 5). Cumpre observar que mesmo aproximando do transe dos orixás, presente no candomblé, no caso do capoeirista, o transe permanece em um tênue, mas ativo controle da consciência vigil (FILHO, 2002, p. 5). ${ }^{1}$ Isso é fundamental posto que estamos tratando de uma luta, ou seja, de um combate e, enquanto tal, torna-se imprescindivel o alerta permanente como condição para o contra-ataque.

Eugene Taylor, ao pensar a transitoriedade da experiência mística em James, observa que mesmo durando apenas "um breve momento na estrutura temporal do experimentador, a sensação de atemporalidade torna sua influência permanentemente duradoura" (TAYLOR, 1996, p. 88).

Entendo permanência como desdobramento, isto é, ação contínua sobre aquele que vivencia a experiência mística ou, o que seria o mesmo, o estado modificado de consciência para Decanio. Para o médico Decanio, o cérebro "funcionaria como um portal de acesso à mente" (FILHO, 2002, p. 5). ${ }^{2}$ Nesse sentido, as vibrações sonoras atuariam diretamente produzindo modificações de estados de consciência e sentimentos (FILHO, 2002, p. 5). Nisso estaria, segundo o mestre, a origem dos orixás que funcionam como espécie de arquétipos de personalidade ou biótipos que eram definidos, originalmente, pelas suas sensibilidades vibratórias aos ritmos e melodias dos toques de atabaque:

Assim, acredito que os cérebros possam ser classificados consoante os seus potenciais vibratórios em categorias de limites de precisão variáveis, como os demais fatos biológicos, que os antigos africanos denominaram de "orixás", tipos fundamentais de comportamento 1 de consciência alcança (desce ou sobe?) determinado estado sob a influência do campo energético sonoro dos atabaques e melopéia do ogans-alabês, o nível de (FILHO, 2002, p. 7). 
Para chegar a sua concepção de estado modificados de consciência, Decanio parte, sem justificar sua escolha, da concepção de Paulo de Tarso expressa em Tessalonicenses, 5, 23: "Que todo o vosso ser, espírito, alma e corpo, sejam atravessados irrepreensiveis para a Vinda do Nosso Senhor Jesus Cristo!" (apudFilho, 2002, p. 8). Para ele, interessa a tripartição paulina delineada pela doutrina da Ressurreição em Corpo, Alma e Espírito para contrapô-la ao que nomeia de "conhecimentos científicos modernos" que, segundo ele, acrescentaram à trilogia paulina os aspectos psico-sócio-culturais alterando, portanto, para uma arquitetura quadrifacetadas do ser humano (FILHO, 2002, p. 8).

Não tenho interesse em realizar aqui uma exposição linear das incursões psicofísicas constitutivas, para Decanio, da natureza humana. Restrinjo-me, apenas, a abordar as relações entre a música e os estados modificados de consciência. Sabemos que a música promove efeitos no cérebro, não somente no humano. Decanio parte, assim, de um quadro geral de influências para chegar à ideia de êxtase, comum a várias religiões e práticas espiritualistas. No caso da sua análise da capoeira, a chave para o transe se encontra no ritmo (FILHO, 2002, p. 22).

O berimbau desempenha o papel central entre os dois niveis, anteriormente citados, ou seja: o manifesto e o oculto ou invisível. Marca determinante, segundo W. James, da vida religiosa (JAMES, 2002, p. 46). A observação mais radical feita pelo mestre Decanio reside em sua afirmação de que não é necessário conhecer a história e a técnica da capoeira. Entre conteúdo e técnicas há o que ele nomeia de capoeira abstrata (FILHO, 2002, p. 22), uma "fonte etérea" que poderia ser acessada por qualquer um que se deixe envolver pelo ritmo e efeitos mântricos dos cantos durante o jogo. Como testemunho, Decanio cita mestre Itapoan que, em conversa, perguntou a Maré como teria aprendido capoeira e o mesmo teria respondido: "vendo os outros jogarem. Gostei. Entrei na roda e joguei" ( $a$ pud FILHO, 2002, p. 22).

Outro exemplo seria o de "Vovô Capoeira", que aos 84 anos teria jogado de forma espontânea em roda do mestre Canelão em Natal/RN. Esses exemplos, mais do que descaracterizar ou negar a técnica adquirida pelos treinos das sequências dos golpes, revelam uma outra possibilidade de compreensão da roda de capoeira como "espaço metafísico" (FILHO, 2002, p. 22). ${ }^{3}$ 
No relaxamento espontâneo, conjugado com a música, o corpo se adapta, como água, propiciando uma interação entre os participantes que fundam a unidade circundante na qual realiza-se uma comunicação atemporal e "anespacial" que Decanio assimila ao satori (FILHO, 2002, p. 23). Trata-se, assim, de uma afirmação na interação em que cada jogador busca, no jogo das vontades de dominio, sobrepor-se, pela percepção direta e antevisão do comportamento, um ao outro.

O próprio Decanio, em conversa com o mestre de judô Yoshida, revela ter experimentado a sensação de não enxergar ou sentir: "notei que não enxergava ou sentia com os órgãos sensoriais habituais a presença ou os movimentos do oponente, apenas sabia o que ele ia fazer!" (FILHO, 2002, p.24). O risco e o perigo, ao contrário de exigirem temor, produzem, graças ao estado modificado de consciência, prazer e estímulo. Diz ele:

Durante o transe capoeirano, o capoerista modifica o seu estado emocional e passa a encarar como prazerosa uma situação de risco imaginário sob a proteção do ritual e vigilância e responsabilidade do Mestre, de modo a facilitar o aprendizado e registo de soluções adequadas às pretensas situações de perigo (FILHO, 2002, p. 20).

Esse aspecto espontâneo do jogo parece contradizer-se com o dominio das estratégias de reação, esquiva e fuga que são possíveis graças ao papel da memória e que, do ponto de vista das experiências exigiria um domínio das possibilidades que o treino e conhecimento técnicos propiciam. O fato é que Decanio parece mais preocupado em equalizar o pragmático da luta com o aspecto involuntário inconsciente que, tanto pode ser alcançado pelo alto nivel técnico, como, também, desenvolvido pela interação e observação decorrentes da vivência direta na roda. Um outro exemplo citado por Decanio de estado modificado da consciência seria o caso de "Pingo de Ouro", capoeirista paraplégico que, sem apoio de muletas, mas motivado pelo axé que envolve a roda, jogava de uma maneira que, segundo Decanio, não conseguira em estado normal de consciência (FILHO, 2002, p. 35).

O caso mais especial de uma ação direta da prática da capoeira, nesse caso como reabilitação dos circuitos nervosos, é o de Mola, Luciano Santos Bispo, que vitimado pela paralisia infantil, aos 7 anos de idade, recuperou os movimentos ao praticar, aos 9 anos, capoeira sob orientação de mestre Zé Dário. Decanio chega a outorgar o estatuto de "milagre" ao caso de Mola que, ao jogar se equilibrava 
perfeitamente, mas ao sair do jogo, apoiava uma das mãos para auxiliar os movimentos ao andar (FILHO, 2002, p. 36).

Para Decanio existe uma inteligência corporal que permite, de forma espontânea e progressiva, um tipo de aprendizado que longe das teorias mais "enfadonhas" possibilitam com que o aprendiz desenvolva suas habilidades sem a preocupação de alcançar uma finalidade objetiva e imediata. Esse tipo de reflexão, muito comum nos escritos de Decanio, revela a capacidade de construção de interfaces culturais que associam capoeira, yoga, judô, candomblé, cristianismo, entre outras manifestações de forma bastante coerente e produtiva. No caso aqui tratado, não seria equivocado pensar que Decanio faz referência a um tipo de aprendizagem que remonta às práticas mais tradicionais como, por exemplo, o tiro ao alvo praticado pelos mestres budistas e que o filósofo Eugen Herrigel em seu belo livro A arte cavalheiresca do arqueiro zen, expressa da seguinte maneira seu exercício árduo e diário no aprendizado da arte do arco:

\begin{abstract}
Aos poucos e cada vez com maior frequência, à medida que se passavam os dias, consegui estirar o arco e mantê-lo teso com o corpo relaxado, sem que pudesse explicar como aquilo estava ocorrendo. A diferença qualitativa entre essas poucas tentativas satisfatórias e as que com frequência fracassavam fizeram com que eu começasse a entender o que significava estirar o arco espiritualmente. Era este, pois, o quid da questão: não se tratava de nenhum ardil técnico, que eu em vão queria descobrir, mas de uma respiração nova, que me abria inusitadas possibilidades de liberação (HERRIBGEL, 1975, p. 35, negritos do autor).
\end{abstract}

O "quid" da questão, tanto para a arte do arco zen budista, como para a capoeira preconizada por Decanio, está nessa compreensão e intimidade espontânea sem preocupações analíticas, como ele mesmo observa, mas em fluência rítmica com o berimbau:

Em conclusão, a capoeira é para ser aprendida no dia a dia das suas rodas, ao lado e sob a supervisão de bons mestres que podem ser até muito bem titulados e cultos, mas sempre dotados da vivência, da experiência e da sabedoria que só o Tempo e a Prática desenvolvem, gravando na intimidade do sistema nervoso, todos os padrões comportamentais, de modo reflexo e espontâneo em circuitos reverberantes bulbomedulares (DECANIO, 2002, p. 29).

É fundamental destacar que o transe, no aspecto aqui tratado une o que há de mais fisiológico ao espiritual. Desde o olhar periférico que, nas palavras de Decanio mantém o controle do campo visual (visão periférica), até as alterações ou modificações da aura, percebidas inconscientemente pelo capoeirista, temos 
uma complexa visão na qual o médico e perito em anatomia humana explora toda a sua vivência no campo da capoeira elaborando uma visão em que metafísica e corporeidade se misturam propiciando um olhar único sobre a capoeira e sua prática.

Em A herança de mestre Bimba - filosofia e lógica africanas da capoeira (1997), no tópico A metafísica da capoeira ${ }^{4}$, texto que acredito complementar o que venho aqui desenvolvendo, Decanio define a capoeira como dança ritual do Ser com a unidade (FILHO, 1997, p. 143). Uma dança que transcende e faz transcender a distinção subconsciente e consciente por uma terceira possibilidade de atenção, bem próxima do que Kitarô Nishida nomeia de experiência pura ou direta (NISHIDA, 1995, p. 41). ${ }^{5}$ No jogo, marcado pela não distinção entre jogadores, o satori é evocado, por Decanio,como similitude da integração ritualística no qual os movimentos e gestos conduzem a uma transfiguração do próprio ser.

William James se refere ao samâdhi como estado de concentração que inicia-se com um ponto específico, como o exemplo da luz dado por Decanio do olhar focado no opositor, passando pela unidade e culminando, junto com a memória e autoconsciência (self-consciousness), na indiferença (JAMES, 2002, p. 311). Decanio não usa a expressão indiferença, mas acredito que possamos tomá-la como o estágio de "automatismo" que vem associado, pelo mestre, ao aspecto instintivo de reação imediata sem o controle volitivo (FILHO, 2002, p. 5). Diz Decanio:

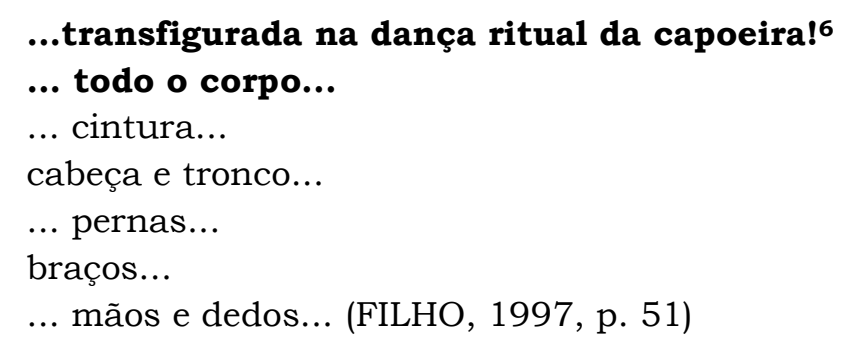

Corpo transfigurado na energia do berimbau ${ }^{7}$ em um espaço infinito em que jogadores e participantes, indistintamente, compõem uma mesma roda, sem dentro nem fora, sem fora nem dentro:

\footnotetext{
... o canto em coro...

... as palmas em sintonia..

... o ritmo/melodia do berimbau...

... num passe de magia ultrapassam os limites da matéria...
} 
... alcançando pela vibração harmônica...

... o êxtase supremo..

... a consciência global...

... o transe coletivo... (FILHO, 1997, p. 147)

Essa passagem se alinha a uma outra que diz:

... alcançamos à Perfeição do Ser...

... a integração psicossomática...

... Mente e Corpo...

... unidos pela magia melódica da capoeira...

... vivenciando o mesmo momento...

... o "Eterno Agora"...

... a concentração mental...

... na perfeição e ritmo dos movimentos...

... remove da consciência...

... os fatores de tensão ou estresse! (FILHO, 1997, p. 202)

Decanio insiste, em várias passagens das duas obras aqui citadas, no candomblé como raiz mística da capoeira. A música como elemento condutor para o estado de "orixás" ou de santo, como ele define, é a porta de entrada para o transe, na melodia do berimbau, ao modo africano do iorubás (Filho, 2002, p.22). O esquema elaborado por ele pode nos ajudar a compreender melhor o tema aqui tratado:

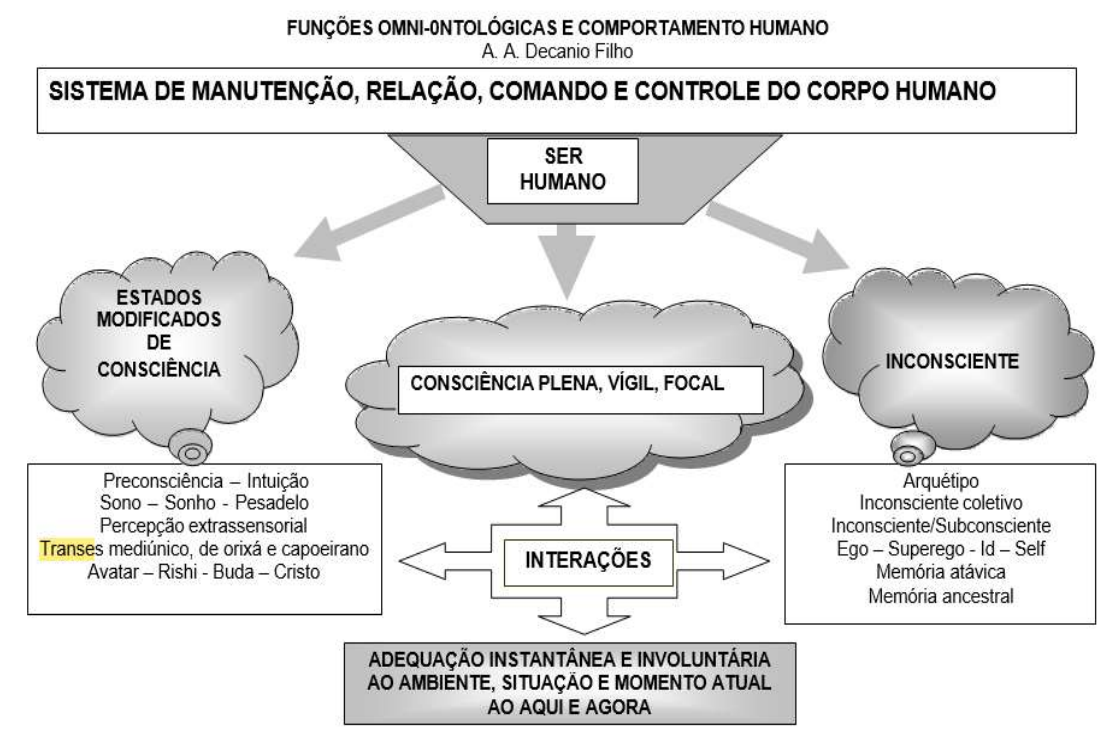

Fonte: Filho, 2002, p. 21

Como se pode observar, Decanio propõe um modelo interativo em que "preconsciência", "consciência plena" e "inconsciente" definem, de modo relacional, o estado modificado emocional adequado a cada contexto ou situação. Explica ele: 
De qualquer modo é necessário acentuar que comportamento do "Ser" humano em face duma situação em dado momento, " $a$ qui-e-agora", é determinando pela interação entre a totalidade dos componentes do "Ser" dependendo, portanto, muito da experiência pregressa ou vivência até aquele dado momento histórico (FILHO, 2002, p.20).

Por essa razão é possível falar no transe capoeirano como uma vigilia pessoal instantânea que se dá em cada indivíduo, de modo particular no agora/já e que se desdobra como interação interpessoal, ou como nomeia Roger Bastide, no caso do Candomblé, intermental (BASTIDE, 1978, p. 204). ${ }^{8}$ Isso fica claro em uma passagem de $A$ herança de mestre Bimba na qual se lê:

... o nivel de consciência pode oscilar...

.... da lucidez da consciência plena da vigilia...

... ao transe profundo de integração cósmica...

... como descrito na linguagem védica...

... da meditação transcendental por Maharishi!(FILHO, 1997, p.50)

\section{Considerações finais}

Que conclusões, portanto, se pode chegar a partir dos elementos aqui elencados sobre as relações possiveis entre "estados místicos de consciência" e "estados modificados de consciência" a partir das reflexões de William James e mestre Decanio? Como é possivel afirmar o aspecto místico, proposto por Decanio, da capoeira à luz da filosofia de James? Para uma resposta mais objetiva, recupero as quatro características que definem, segundo James, os estados místicos: inefabilidade, qualidade noética, transitoriedade e passividade. No que se refere ao caráter inefável, embora não haja nenhuma reflexão, explícita, aplicada por Decanio ao transe, duas passagens podem ser destacadas como pistas para o aspecto não verbal que caracteriza o cerne da experiência de aprendizagem e prática da capoeira. O primeiro, figura em A herança de mestre Bimba:

...interrogação muda e silenciosa...

...que se refletia inexplicavelmente em minha cabeça...

...ao lado da observação...(FILHO, 1998, p. 96) 
A segunda, presente em Transe capoeirano diz: "A palavra escrita ou falada deve acompanhar e esclarecer os fatos e não ser apenas pronunciadas ou encadeadas logicamente" (FILHO, 2002, p. 29). Obviamente que não estamos diante da expressão de um limite entre o dizer e a experiência, que caracteriza a tradição apofática ou negativa, mas penso ser possivel sustentar, graças ao aspecto de interioridade e particularidade que o jogo exige, não se reduzindo aos manuais ou técnicas objetivas, "cada alunu teinh seu jeitchu...particular...pessoal...intransmissivel", como dizia o mestre Bimba (FILHO, 1998, p.90), uma sabedoria, uma vivência que comporta, sim, um aspecto de inefabilidade.

No que diz respeito à qualidade noética, sustentada em narrativas realizadas por aqueles que experimentaram o transe místico, não resta dúvida de que esta característica é pressuposta no transe capoeirano e, também, na própria tarefa do mestre Dacanio como arauto de uma verdade que é, em última instância, a própria capoeira:

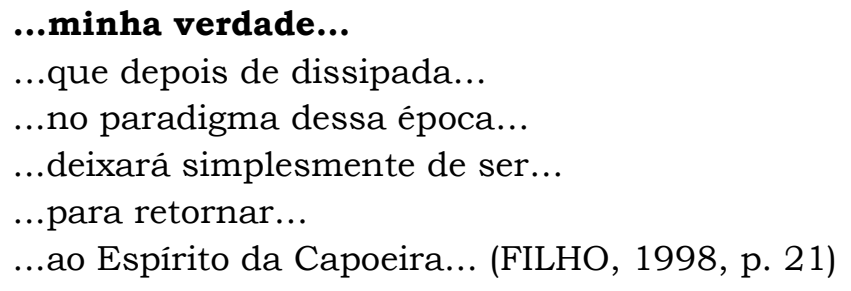

De fato, o verdadeiro conhecimento assume, para Decanio, a imagem do olhar. Um ver que não é simplesmente um ato objetivo fisiológico, mas o desenvolvimento de uma perspectiva determinada que faz da visão um modo próprio de agir e estar no mundo: "A capoeira é o aprendizado do modo de ser" (FILHO, 2002, p. 24).

No que se refere à transitoriedade da experiência, não resta dúvida de que o transe capoeirano, embora com desdobramentos na vida cotidiana, se dá exclusivamente nos instantes marcados pelo som e ritmo do berimbau. Trata-se do instante atemporal do jogo, já abordado anteriormente, e que está presente, de modo mais expressivo, no texto da A herança de mestre Bimba.

Por último, à passividade da experiência mística ${ }^{9}$, associo o aspecto de distensão contínua exigida durante o jogo. Decanio chega mesmo a utilizar o termo “inconsciente" para definir o estado de alerta que não é tensão, mas como já dito, pode ser compreendido como atenção característica, também, da visão periférica. 
Diria que, durante o transe capoeirano, no qual já não há opositores, mas jogadores, é a própria capoeiragem que se manifesta e define as ações dos que se deixam guiar pelos toques do monocórdio de Exú.

\section{Referências bibliográficas}

BASTIDE, R. O candomblé da Bahia (Rito Nagô). $3^{\circ}$ ed. Trad. de Maria Isaura P. de Queiroz. São Paulo: Ed. Nacional, 1978.

BEZERRA, C.C.; TAVARES, L.C.V. Capoeira: devir homem, devir animal.Prometheus - Journal of Philosophy, n. 9(20), 2016.

BEZERRA, C. C.; TAVARES, L.C. V.No limite da roda: capoeira e pensamento. TAVARES, L.C.V. (org.).Capoeira: recortes e percepções. Curitiba: CRV, 2016.

CAMPOS, H. Capoeira Regional: a escola de Mestre Bimba.Salvador: Edufba, 2009.

FILHO, A.A. D.Transe capoeirano, um estudo sobre a estrutura do ser humano $e$ modificações de estados de consciência durante a prática da capoeira. Salvador: CEPAC - Coleção São Salomão, 2002. Disponivel emhttp://www.capoeira.art.br/site/site/administrator/arquivos/download/\%5B monografia\%5D_-_transe_capoeirano.pdf

FILHO, A.A.D. A herança de Mestre Bimba, Filosofia e Lógicas africanas da capoeira. Salvador: CEPAC - Coleção São Salomão 1, 1997. Disponível em https://www.cppa.com.br/attachments / File/Artigos/a_20heran_C3_87a_20de_2 Om_20bimba_202ed.pdf

FILHO, A.A.D. A herança de Mestre Pastinha. Salvador: CEPAC - Coleção São Salomão 3, 1997a. Disponivel emhttp://www.capoeira.art.br/site/site/administrator/arquivos/download/\%5B monografia\%5D_-_a_heranca_de_pastinha.pdf

GALM, E.A. The berimbau: soul of Brazilian music. Mississippi: University Press of Mississippi, 2010.

HALLIWELL, M.; RASMUSSEN, J.D.S. William James and the Transatlantic Conversation. Pragmatism, Pluralism, and Philosophy of Religion. Oxford: Oxford University Press, 2014.

HERÁCLITO.Fragmentos. Trad. de Emmanuel Carneiro Leão. Rio de Janeiro: Tem-po Brasileiro, 1980.

HERRIGEL, E. A arte cavalheiresca do arqueiro zen. Trad. de J.C. Ismael. São Paulo: Pensamento, 1975.

JAMES, W. Varieties of Religious Experience. A Study in Human Nature. London and New York:Routledge, 2002.

NISHIDA, K. Indagación del bien. Trad. de Alberto Luis Bixio. Barcelona: Gedisa, 1995. 
SERRES, M. Variações sobre o corpo. Trad. de Edgard de Assis Carvalho e Mariza P. Bosco. São Paulo: Bertrand Brasil, 2004.

SUZUKI, D.T. Introdução ao Zen-budismo. Trad. de Murilo N. de Azevedo. Rio de Janeiro: Civilização Brasileira, 1971.

VASCONCELOS, N. Naná Vasconcelos, The Voice of the Berimbau.Greg Beyer,
percussive notes, $48, \quad$ october 2007. Disponivel emhttps://www.pas.org/publications/percussive-notes.

TAYLOR, E. William James on Consciousness beyond the Margin.New Jersey: Princeton University Press, 1996.

${ }^{1}$ Roger Bastide, ao se referir aos Orixá, aponta para uma "anatomia mística" que responde à lei das
correspondências, ou seja, o microcosmo reflete o macrocosmo (BASTIDE, 1978, p.157) e aponta
para o fato "real" do transe, bem como para o seu estado de inconsciência demonstrado pelo com-
pleto esquecimento ao despertar (Bastide, 1978, p.205).

${ }^{2}$ Acredito que Decanio concordaria com a perspectiva de James para o qual o cérebro, ao contrário da visão da biologia moderna, não seria um mero produtor da mente, mas um transmissor de consciência como bem ressalta Eugene Taylor (1996, p.83).

3Sobre o tema ver: BEZERRA, C.C. e TAVARES, L.C.V., 2019. p.75-87.

4 Expressão originalmente utilizada por mestre Pastinha e que figura como subtitulo dos seus escritos Quando as pernas fazem mizerês. Material digitalizado em 2003 por Teimosia (Hilton Bruno de Almeida Sousa), parte I, Caderno albo, disponivel em https://www.capoeirashop.fr/img/cms/Manuscritos-Mestre-Pastinha-full.pdf

5 Embora o tema exija um maior desenvolvimento, dada especificidade do emprego da noção de "experiência pura" utilizada por Kitaro Nishida, não é desproporcional associá-la ao que sustenta Decanio, principalmente, no que se refere à relação entre experiência não dualista e a atenção, diz Nishida: "a esfera da experiência pura coincide com a esfera da atenção. Mas a esfera da experiência pura não está necessariamente limitada a um só foco de atenção. Sem agregar a mínima dose de pensamento, podemos deslocar nossa atenção dentro do estado em que sujeito e objeto não estão separados" (Nishida, 1995, p.44).

6 Os negritos fazem parte do estilo de escrita de Decanio.

7 Sobre o aspecto espiritual do Berimbau, Eric A. Galm ressalta sua presença em culturas africanas e diaspóricas africanas como expressão de elementos sobrenaturais que mantém o espaço ambíguo que engloba o sagrado e o profano, o mundo e um "outro" para o qual o acesso só é permitido aos pés do berimbau (Galm, 2010, p. 30).

8 Roger Bastide entende o transe como um "jogo" bem regulamentado em que vários transes, complementam uns dos outros intervindo e promovendo estimulos. Por essa razão, ele prefere o termo "intermental" para distinguir um transe coletivo que seria resolvido isolando os individuos (Bastide, 1978, p.204).

9 É preciso ressaltar que Decanio não emprega os termos mística e místico para caracterizar o transe capoeirano. Quando o faz, conforme já destacado anteriormente, é para referir-se à sua raiz mística, ou seja, o candomblé. 
Recebido em 05/05/2021 Aceito para publicação em 09/06/2021 


\section{O Discurso sobre Deus na Pós-Modernidade}

The Discourse on God in Postmodernity

Elias Gomes*

https://doi.org/10.29327/256659.12.2-18

SLOTERDIJK, Peter. Pós-Deus. Petrópolis: Vozes, 2019. 324 p.

Peter Sloterdijk está sendo atualmente considerado um pensador "original". No mundo acadêmico, subentende-se por originalidade aqueles pesquisadores que, supostamente, por convenção de seus pares - tiveram suas teorias ou ideias "imortalizadas". No que diz respeito ao respectivo livro, traduzido do original Alemão (NachGott) para língua portuguesa por Markus A. Hediger, publicado em 2019 pela Editora Vozes, é perceptivo que as áreas da teologia e da filosofia contemporâneas entram em jogo novamente, bem como questões de ordem política, que assiná-la os desenvolvimentos culturais e técnico-científicos imediatos.

Entretanto, embora o livro esteja listado entres os títulos mais recente publicados por Peter Sloterdijk, seus aportes teóricos e conteúdos mais expressivos não é de todo novo. Por exemplo, dos 12 capítulos contidos no livro, temos: manuscritos de palestras proferidas, prefácios, apresentações de pesquisas bem como capitulos de outros livros publicados anteriormente. Ainda sobre a configuração dos capítulos, em termos numéricos, 1 deles datam de mais de 20 anos; 3 são do final da década de 90 do século passado; 7 tem mais de 10 anos; sendo que, somente 1 de fato (capitulo 2) representa a data da publicação do livro em questão, mais precisamente em 2017.

No que diz respeitos aos aportes teóricos e conteúdos mais expressivos, destaca-se a descrição do fenômeno da globalização, começando por seus desenvolvimentos preliminares no final do século XX, cuja máxima repousa sobre as

`É Professor de Filosofia pela Secretaria da Educação do Estado de São Paulo (SEE/SP). EspecialistaemFilosofiaContemporânea (FACEL). MestreemCiência da Religião pela UniversidadeMetodista de São Paulo (UMESP). Atualmente o mesmodesenvolvepesquisasnasáreas de Filosofia, Educação e CulturaReligiosa. E-mail: filosofia.elias@hotmail.com. 
questões implicadas da afirmação ou do suposto reconhecimento da "morte de Deus". Nesse ponto específico, Peter Sloterdijk caracteriza Deus ou a ideia de Deus como "a maior fonte de cobertura de seguro". Tal afirmação, do ponto de vista histórico, tem em tese validado todas as religiões (pelo menos as monoteístas) supostamente "liberando" os possiveis paradoxos que tiveram consequências devastadoras desde a Idade Média até os temos modernos: o fundamentalismo triunfante é o seu pior experimento.

Proporcionalmente, o grande desafio filosófico do respectivo livro, está em tentar responder quais são os desenvolvimentos associados à frase visceral "Deus está morto", que reverbera desde, no mínimo, o final do século XIX? Isto é, seria ela apenas uma descrição de uma espécie de mudança de mentalidade? Seria ela uma representação contextual do que de fato aconteceu? Deve ela ser compreendida como um prognóstico que dá fim a todos os argumentos inter-religiosos?

O substrato temático extraído do livro, pode ser catalogado e didaticamente conduzidos, a partir dos principais assuntos, tais como: (1) A tautologia da metafísica tradicional e "morte" de Deus como reflexo consequencial; (2) A reforma protestante como estandarte de uma religiosidade da "negação" do mundo; (3) "Cosmologia" e religião; (4) A teologia do interior ou a espiritualidade subjetivada; (5) A ruptura Jesus ou bastardo de Deus; (6) Aprimoramento do ser humano; (7) Filosofia das neuroses; (8) A Latência do escondimento; (9) O imperativo místico; (10) O imperativos absolutos e categórico; (11) Novidades sobre a vontade de Crer; (12) O mundo religioso Willian James.

No que diz respeito a temática da tautologia da metafisica tradicional e entrelaçamento da "morte" de Deus como reflexo consequencial, Peter Sloterdijk apresenta a mesma, a partir do primeiro capítulo do livro intitulado: Crepúsculo dos deuses. De forma didática e, procurando fazer uma espécie de "analogia" entre filosofia e mitologia grega, nosso autor procura a pontar que o crepúsculo da civilização ocidental começa no instante em que os habitantes da grande construção cultural são tomados pelo pressentimento de que nem mesmo os sistemas humanos mais sólidos do presente foram de fato construídos para a eternidade (p. 9). Isto é, eles sempre estarão sujeitos a uma fragilidade inerente que é costumeiramente chamada também de "historicidade". Subintende-se, portanto que a historicidade significa para as civilizações o que a mortalidade significa para o indivíduo (p. 9-10). Na verdade, a imortalidade era a única característica dos deuses gregos; pois em geral no que dizia respeito à sua conduta, esta, com 
sua irônica humanidade demasiada, dificilmente poderia ter sido diferenciada do comportamento humano (p. 7).

Nesse sentido, a tautologia da metafísica supostamente estaria associada a filosofia da "morte" de Deus, justamente por causa do zelo suprematista, protagonizado pelos teólogos religiosos que por vezes insistiram em adornar seus Deus com os atributos mais brilhantes, tais como: onipotência e onisciência (p. 13-14). Para Sloterdijk, eles não levaram em consideração que, a proclamação simultânea desses atributos, desencadeiam uma contradição real de natureza altamente explosiva. Ele diz: [...] Ou Deus é todo-poderoso, caso em que sua vontade criativa permanece livre por todo o futuro e só pode ser espelhado por seu conhecimento apenas posteriormente; ou ele é onisciente, caso em que teria esgotado todo seu poder criativo; apenas assim ele poderia olhar para o universo do "ter sido" numa eterna happy hour (p. 14). Nesse ambiente, a premissa da "morte" de Deus é no minimo justificável.

Na segunda temática (a reforma protestante como estandarte de uma religiosidade moderna da "negação" do mundo) Sloterdijk, desenvolve o segundo capítulo de seu livro, o apontando para o fado de que após o processo histórico que desencadeou as reformas religiosas na Europa do século XVI, mais precisamente aquela protagonizada por Martim Lutero, passou a se defender, um "novo" modus operandi de uma espécie de religiosidade moderna e excêntrica capaz de estabelecer a "negação" do mundo (p. 41-42). Isto é, a tentativa argumentativa luterana que afirma o descrédito que a "meretriz razão", incentivada através do supervalorizado Aristóteles, defensor da tese segundo a qual o ser humano seria capaz, por esforços próprios, de desenvolver virtudes magnificas (p. 42). Mas, Lutero não quiz manter a mesma postura do contramundo monástico, pois o mesmo não servia para esclarecer a indisposição radical de sua existência (p. 47).

Assim, preferencialmente pautado no termo agostiniano peccatumoriginale[pecado orginal] Lutero teria então, "refutado" o elogio próprio de Deus no final de cada dia da criação. Na prática, após o pecado de Adão e Eva, ele via que na maioria das vezes, as coisas não eram boas e jamais eram valdebonum(p. 48). Para Sloterdijk, a reforma protestante é fruto de "desespero existencial" de seu principal protagonista, forjado a partir de uma antropologia negativa, incapaz de apostar numa analogia entis ou na teologia natural (p. 52-59). O lado positivo desse processo, repousa sob o paradoxo entre ação enérgica e a inatividade ex- 
trema; entrelaçando-se de um modo praticamente sem precedentes em termos de uma história das ideias da alma (p. 53).

Já a terceira e a quarta temática ("cosmologia" e religião e teologia do interior ou a espiritualidade subjetivada) é possivel apresentá-las como fenômenos intrinsecamente correlatos. Exemplificando: o ato de repulsa ou de "negação" do mundo, protagonizado por Lutero no século XVI, supostamente remeteria (por analogia) ao pensamento gnóstico do cristão primitivo, desencadeando assim, mais uma vez, a temática entre cosmologia e religião. Portanto, a irrupção de formas de pensamento gnóstico moderno se impõe sobretudo na história a partir dessa negatividade mundana (p. 74-75). Tal evidência, porém, não é meramente uma questão lógica. Sloterdijk afirma: [...] Dela depende o peso de autointerpretações mais elevadas da "existência" humana; sim, a própria "existência" não teria qualquer significado para nós, sem a revolução das relações de negação no espaço de um pensamento gnóstico e cristão primitivo (p. 75). Para heresia gnóstico moderna, a negação do "mundo" resulta do pavor dos poderes do mundo. Sloterdijk, defende de maneira emblemática, que desde de sempre, a vitrine em que as ruindades do mundo se expõem de forma espetacular é o poder político - na percepção das perspectivas daqueles que sofrem sua injustiça na forma de repressão e exploração (p. 77).

A grande ironia ou resultado subsequente de todo esse processo é sem dúvida, o que Sloterdijk vai chamar de "Pré-escola teológica à teoria do interior comum" (p. 103). Trata-se no reconhecimento de que, embora a religiosidade moderna seja de fato construída a partir da "negação" do mundo exterior em seus aspectos estrutural, cultural e político, tal ambiente ironicamente acabou por permitir e fomentar o desenvolvimento latente de um autoconhecimento do mundo interior. É como se Deus não ficasse "sem mundo". Isto é, o vidente infinito ou a visão máxima, se contrai em mim, num mínimo, e, age nesse sentido específico em mim (p. 136). Entretanto, a habitação de Deus em mim, não pode ser pensando como uma espécie de o gênio na garrafa; sua lógica é semelhante a uma transferência de oficio ou investidura, na qual os poderes oficiais são transferidos pelo senhor ao portador do oficio (p. 136). Assim, a essência desse ensinamento consiste no fato de que o meu "ser eu" assume um caráter oficial e minha subjetividade é concebida e autorizada como função de planejamento na economia de Deus. De maneira impressionante, a extensão não extensa de Deus, determina, portanto, em cada aspecto, o sentido de imanência ou de "ser em" (p. 136-137). 
Temos então a quinta temática. A chamada ruptura Jesus ou bastardo de Deus, é apontada por Sloterdijk, sobre aquela antiga tentativa de mais uma vez demonstrar que, embora a tradição cristã tem sempre procurado nos apresentar o Filho de Deus de maneira extremamente conservadora, na prática a realidade seria outro. Para o filósofo alemão, a identidade do Filho com o Pai não gera um contínuo genealógico, mas o rompe (p. 185). Na doutrina da encarnação, Deus gerou um filho ilegítimo com Maria. Portanto, a legitimação posterior, porém, desse filho transcendental só podia ser testificada por um esforço adicional (p. 185). Paradoxalmente, a fim de preservar a etiqueta, essa criança deveria ser criada num lar de um casal regular. Entretanto, uma mãe, capaz de ter um caso com o Verbo divino, e um pai, que aceitava isso, formam um casal não muito comum, contrariando na esfera da ação o modelo de "Família Sagrada" (p. 185). Porém, o que poderia ser tratado com uma espécie de "tragédia irreconciliável", acabou desencadeando um processo restaurador e motivacional para todos os filhos da cristandade. Isto é, quando o filho de todos dos filhos [Jesus Cristo ] conseguiu apresentar sua ilegitimidade evidente pela instrumentalidade de sua união com o Pai como uma forma superior de legitimidade, este, consequentemente, acabou acolhendo todos nós como "filhos ilegítimos" também, pois aonde as sementes voadoras do Espírito se espalham, tornam-se inimagináveis os frutos benéficos para as próximas gerações (p. 188-189).

O "aprimoramento do homem" e a "filosofia da neurose" podem ser pensados conjuntamente. No primeiro caso, a temática aparece no sexto capítulo do livro. Sloterdijk está convencido que os cidadãos do início da Modernidade foram convocados a se apresentar como especialistas de seu próprio sofrimento, prescrevendo -lhes o padrão da imitação de Cristo como caminhada ideal pela vida ( $\mathrm{p}$. 200-201). Porém, isso não deve ser entendido como uma espécie de programa de criatividade. Para o cristianismo, o ser humano não é interessante por ser esteticamente virulento. Não temos uma tendência natural de compor óperas ou de pintar pinturas. Teologicamente, o que vale para o "aprimoramento do homem" é que ele unicamente se torne semelhante a Cristo (p. 201). Ora, se olharmos para o projeto da "clonagem" de Cristo a partir daqui, percebemos o quanto já descemos para o nivel do pragmático, vivenciando a ineficiência de uma suposta antropotécnica (p. 202-203).

É justamente nesse tipo de ambiente que se costuma nascer as neuroses. A próxima temática (capítulo 7), demonstra que o sujeito neurótico é sem dúvida fruto do lema de uma sociedade iluminista pautada as custas da maioridade evo- 
cada por Immanuel Kant, que era definida como faculdade de se servir da própria razão sem o desempenho de outro - principalmente a tutela religiosa (p. 207). Isto é, sem a Reforma protestante, as ideais iluministas de liberdade e igualdade seriam sufocadas pelo medo e pela opressão da Igreja. Assim, a Revolução Francesa teria que esperar, e Igreja e o Estado absolutista continuaria. Em sua forma política mais elevando, a história da filosofia descreve o modelo de pensamento da transição da sociedade feudal para a sociedade burguês - ela formula a matriz daquele processo de emancipação que deveriam levar da dominação de pessoas para dominação de direito; da psicopolitica da ordem e da obediência para a psicopolítica da autoterminação de indivíduos iguais e livres (p. 207).

Consequentemente - no ponto de fuga da ideia de maioridade temos uma fantasia de autossuficiência radical e de desligamento definitivo da influência material e psíquica dos outros. O sentido da educação burguesa consiste em influenciar os indivíduos de tal forma que surja neles a ideia de que sempre teriam desejado a maioridade - independemente de qualquer influência (p. 208). Entretanto, a existência humana possui "necessidades especiais". A cultura nãoteológica da modernidade iluminista acabou tendo que se curvar diante da cultura da psicoterapia cuja máxima possui princípios inconscientes de religiosidade. Ele diz: [...] A psicanálise como prática individualizada do êxodo repete com cada cliente um esquema que, até hoje, marca a história do povo judeu. Cada paciente reproduz realmente um exodo privado mais ou menos discreto do Egito sob a liderança de psicoterapeutas que, normalmente, não admitirão que são sucessores mosaicos (p. 221).

Na continuidade, (Capítulo 8) Sloterdijk nos apresenta de maneira articulada a temática da Latência oculta no fenômeno do escondimento (p. 231). No respectivo capitulo, o autor procura estabelecer um diálogo com Heidegger. Segundo o mesmo, na perspectiva Heidegger, o processo que desencadeou o conhecimento tecnológico e científico era uma técnica de fazer o que é implícito, interno, escondido, seja explícito, isto é, trazê-lo ao descoberto (p. 232-233). A modernidade significa, nesse sentido, "explicar". Porém, a modernização não é a revolução, isso foi um mal-entendido, mas não no sentido lógico comum de explanar, e sim, no seu sentido cognitivo de trazer à superficie, ou seja, o jogo da linguagem central da atividade filosófica e, das ciências, consistia naquilo que seria o "justificar", "explicar" ou fornecer um motivo, a razão de algo (Begrïnden). Entretanto, a ironia está na revelação descobridora, através da qual tudo quanto seja racional e relativo é patenteado, não é ela própria racional nem relativa. O "espaço" do 
verdadeiro, enquanto não oculto, surge singularmente como uma ilha cheia de proporções comensuráveis, do oceano do incomensurável, do desproporcionado. O descoberto concebivel encontra-se no terreiro da lethe, do desmedido, do inconcebivel. Onde os homens estão, sempre o haverá um terreno avançado do monstruoso que está encoberto (p. 235-236).

Finalizando - é possivel perceber que nos últimos capítulos livro (9 á 12) a tentativa de o autor apresentar alguns aspectos que norteiam a religião ou religiosidade da chamada era pós-moderna. Trata-se em procurar compreende as "novidades" do mundo religioso (p. 276). Nesse sentido, começando pelo imperativo mistico, Sloterdijk vai dialogar como autores como SørenKierkegaard e Martin Buber. Ambos defendem uma religiosidade pautada numa experiência mística que transcendem os estatutos de uma religião institucionalizada. Em se tratando de Kierkegaard, a principal ideia de Sloterdijk, foi nos apresenta o suposto drama que o filósofo dinamarquês enfrentou ao ter que lutar, como sua própria existência, estabelecendo a diferenciação entre o gênio e o apostolo (p. 245-246). Sloterdijk diz: [...] não há dúvida de que as simpatias de Kierkegaard pertenciam ao tipo apostólico, no qual opera de forma irrestrita a seriedade do oficio doutrinal cristão - trata-se, porém, de simpatias que não consegue negar que Kierkegaard se via condenando a ser um gênio - um mero escritor que não sentia os plenos poderes do mandado apostólico (p. 246). Sobre Martim Buber, nosso autor, vai demonstrar que embora o editor das Confissões extáticas, fora a princípio, imaginado com um autor igualmente distante de todas as formas da religião teísta, seja ela judaica, muçulmana ou cristã; sobretudo na medida em que o mesmo vai utilizar de expressões aparentemente metarreligiosa da vivacidade psíquica; na prática, o que se percebe, é a presença de elementos distintivos de um imperativo místico latente (p. 247-248).

Entretanto, a pós-modernidade é cheia de contrastes. Embora podemos falar de suposto "reavivamento" da mística, a configuração de uma sociedade capitalista e globalizada, acabou concomitantemente formatando um tipo de imperativo categórico cuja máxima propõe um comportamento nocivo, não só para homem, mas sobretudo para o próprio planeta (p. 273). A palavra-chave nessa realidade mais recente é preocupação ecológica. Tal preocupação, existem prazos impostos por processos físicos externos - e ao contrário do que acontece na história humana, onde sempre podemos esperar uma segunda ou terceira chance para recuperar o que foi ignorado até então, nos processos ecológicos, domina uma espécie de lei da irreversibilidade (p. 272). 
Por fim, o conceito de Pós- Deus, precisa ser pensado a partir da secularização no sentido filosófico e ontológico do termo. Trata-se da absolutização do seculume a liquidação concomitante das duas grandezas transmundanas ou sobrenaturais não seculares: Deus e alma (p. 300). Com isso, nesse contexto - a segunda grandeza extramundana, a alma, perde seu fundamento na parceira com Deus. É necessário buscar salvação. Assim, citando Willian James, Sloterdijk, conclui: [...] para homem a chance de salvação é mais importante do que a própria salvação (p. 321).

Recebida em 02/05/2021 Aceita para publicação em 10/05/2021 


\section{Nominata de Pareceristas 2021-2}

\section{Alagoas}

Universidade Federal de Alagoas: César Leandro Santos Gomes

\section{Amazonas}

Universidade Federal do Amazonas: Rodrigo Fadul Andrade

\section{Bahia}

Universidade Federal da Bahia: Edward John Baptista das Neves MacRae

\section{Brasilia}

Universidade de Brasília: Sérgio Ricardo Coutinho dos Santos

\section{Ceará}

Universidade Estadual do Ceará: Emanuel Freitas da Silva

\section{Espirito Santo}

Faculdade Unida de Vitória: David Mesquiati de Oliveira

\section{Goiás}

Universidade Estadual de Goiás: Gilson Xavier de Azevedo

Universidade Federal de Goiás: João Guilherme da Trindade Curado

\section{Maranhão}

Universidade Estadual da Região Tocantina do Maranhão: Moab César Carvalho Costa

\section{Minas Gerais}

Pontificia Universidade Católica de Minas Gerais: Paulo Agostinho Nogueira Baptista

Pontificia Universidade Católica de Minas Gerais: Rodrigo Coppe Caldeira Universidade Federal de Juiz de Fora: Sônia Regina Corrêa Lages 
Pareceristas

Universidade Federal de Minas Gerais: Isnara Pereira Ivo

\section{Paraiba}

Universidade Federal de Campina Grande: Arilson Silva de Oliveira

\section{Paraná}

Universidade Estadual de Maringá: Marcia Regina de Oliveira Lupion

\section{Pernambuco}

Universidade Católica de Pernambuco: Fabiano Aparecido Costa Leite

Universidade Católica de Pernambuco: Zuleica Dantas Pereira Campos

Universidade Federal de Pernambuco: Edwin BoudewijnReesink

Universidade Federal de Pernambuco: Roberto Mauro Cortez Motta

\section{Piaui}

Universidade Federal do Piauí: Celso de Brito

\section{Rio de Janeiro}

Universidade do Estado d Rio de Janeiro: Gerson Lourenço Pereira

Universidade Estadual do Norte Fluminense Darcy Ribeiro: Fábio Py Murta de Almeida

Universidade Federal do Rio de Janeiro: Gustavo Arantes Camargo

Universidade Federal Fluminense: Guilherme Ferreira Oliveira

Pontifícia Universidade Católica do Rio de Janeiro: Sonia Maria Giacomini

\section{Rio Grande do Norte}

Universidade do Estado do Rio Grande do Norte: Waldney de Souza Rodrigues Costa

\section{Rio Grande do Sul}

Universidade Federal de Santa Maria: Beatriz Teixeira Weber 
Pareceristas

\section{Santa Catarina}

Universidade Federal de Santa Catarina: José Pedro Simões Neto

\section{São Paulo}

Centro Universitário Toledo: Carlos Eduardo MarottaPeters

Centro Universitário Salesiano São Paulo: Antonio de Lisboa Lustosa Lopes Instituto São José: Renan Santos Mattos

Universidade Católica de São Paulo: Bernadete Alves de Medeiros Marcelino Universidade de São Paulo: Silas André Fiorotti

Universidade Estadual de Campinas: SinuêNeckel Miguel

Universidade Federal de São Carlos: Leandro Leal de Freitas 